$\therefore$ i

te.

t. 


\section{LIRRARY \\ THE NEW YORK BOTANICAL GARDEN BRONX, NEW YORK 10458}


$$
\text { , }
$$ 
QL

66

M36

W6

$1896 a$ 
DEDICAIED BY PERMISSION

To

HER MAJESTY THE QUEEN. 



\section{PREFA C E.}

THE increasing interest taken in the genus Masdevallia, and the large number of species now in cultiva. tion, seemed to form a sufficient reason for publishing the present Monograph, which will be made as complete and exhaustive as the numerous difficulties attendant upon such an undertaking will allow. One of the greatest of these difficulties arises from the impossibility of referring to the late Professor Reichenhach's immense collections of dried specimens, drawings, and unpublished descriptions, now sealed up, by the eccentric conditions of his Will, in the Vienna Museum for a period of 25 yenrs from the date of his death, 1889. In thus rendering his collections inaccessible, Professor Reichenbach has precluded any comparison with many types of the genus Masdevallia, of which the greater number of species were first named and described by him.

The drawings contained in the earlier Parts of this work will be prepared from Plants grown at Newbattle Abbey; thase in subsequent Parts will be taken from specimens liberilly contributed by many persons interested in the genus. Besides a hand-coloured lithograph (natural size) of each species in cultivation, a rignette engraving from a photograph will be given, except in those cases where it is found impossible to obtain a photograph of the perfect plant. Drawings also of numerous species entirely unknown in this country, or known hitherto only as dried specimens, are generously promised by Consul F. C. Lehmann, whose exceptional advantages as a skilled botanist collecting for many years in those regions of Central and South America where alone Masdevallias are to be found, place him at the head of the authorities upon the genus. His drawings will be published in later Parts of the work, with names and descriptions supplied by him, and with a chapter on the geographical distribution of the genus, accompanied by a map. For each species which he has himself collected, be contributes a note stating the temperature and elevation of the locality in which he has found the plant.

The Plates issued in each Part will be arranged-for temporary convenience-in alphabetical order, and at the end of the work a synopsis will be given, indicating the sections into which the genus is divisible, and the order in which the entire book should be bound.

Much pleasure is felt in thanking numerous friends for the help which they have given towards the progress of the work, especially those gentlemen on the Botanical Staff of the British Mfuseum of Natural History, whose kind and willing aid has greatly lightened the task of preparing the text. Thanks are also due to Mr. F. W. Mоове, of the Royal Botanic Gardens, Glasnevin, Dublin, for sending many rare specimens, which have proved of invaluable assistance in the completion of the Plates. Sir Trevor Lawrexce, Bart., M.P., Mr. Sydsey Courtauld, Mr. Harky Vittch, and Mr. James O'Bries have also been most generous in supplying useful specimens.

It may be of interest to friends of the late Professor Reichenbach to know that some of the first Plates prepared for this work were submitted to him shortly before his death, and that they met with his cordial approhation. By his advice a few slight additions were made in the dissections, as for instance, the apex and section of each leaf and the apex of the column.

Flureace H, Woolward, Bertov,

Grasthus. 


\section{.}




\section{GENUS MASDEVALLIA;}

ITS HISTOPY,

GEOGRAPICAL DISTRIBUTION, ETC.

IN writing the history of the Genus Mastluallia, there is little to be added to the information already published. A few new species bave been recently discovered
and introduced to horticulture, but the keen interest in them which prevaled a few rears ago, expecially during the lifetime of Professor Reichenbach, has almost died out, and we no longer hear of fabulous prices paid for a fragment of a plant, consisting, perhaps, of only two or three leaves. This interest, which almost amounted to a mania, was, no doubt, partly caused by Reichenbachs glowing and grotesque descriptions of the new species brought to his notice, for, since his death, it is remarkable that purchasers have been less eager to buy, and dealers consequently less enterprising in collecting, while the reduction of prices has brought even mre species within the means of almost every horticulturist.

The first Mereterallin kuown to seience was $\boldsymbol{M}$. uniflora, which was discovered by the Spanish botanists, Ruiz and Pavon, in the Andes of Peru, during their residence in that country firm 1775 to 1794 , for the purpose of exploring the Cinchona forests in the interesti of the Spanish Government. They founded upon it a new Genus in homour of their fellow-countryman Josepho Masdevall, a phrsician at the Court of Spain. II. miflurf has never since been seen in its native habitat by any botanist, and omly the most persistent enquiry has enabled me to collect the details of its history given in this work, with the first coloured drawing of the plant ever made. No other examples of the new Genus were made known until 1809, when $\mathbf{M}$. infracta was discovered in Brazil by Descourtilz, a French botanist and traveller, and this species, of which living plants were imported in 1828 , was the first to flower in cultivation. In 1 Nin 2. . C'mulut! was discovered, and during the next twelve or fourteen years several other species, and from that time onwards their number has steadily increased, until, at the present time, between eighty and ninety are cultivated, and many others are known as Herbarium specimens or by deseription only.

The greographical distribution of the Genus extends from Mexico, in about $30^{\circ} \mathrm{N}$. lit.. south-eastwards through the central Cordillera of Costa Rica, and the Isthmus of Panama, then ruming north-eastwards as far as the coast ranges of Venezuela, and southwards towards its centre in the Andes of Colombia. The southern limit on the westerm side of the continent is reached in the Peruvian Mountains at $16^{\circ}$ or $17^{\circ} \mathrm{S}$. lat., and on the eastern side in the Organ Mountains of Brazil, at $23^{\circ} \mathrm{S}$. lat, where nine or ten species have been discovered. One is recorded from Mount Roraima, two or three from the hills of French and Dutch Guiana, and one only from the low alluvial region in the interior of the coutinent, the habitat of which is indicated on the annexed map by Senhor Rodriguez, hitherto the only discoverer of a Musderallin so far from the seacoast. The principal part of the area of greographical distribution-marked in yellow on the map-was indicated by Consul Lehmann himself, and may therefore be relied on as accurate.

Mastevallias have a very remarkable vertical nange, extending almost from the level of the sea, where Consul Lehmamn has found them upon the trunks and roots of trees yrowing close to the shores of the Pacific Ocean, and from 195 feet in the marshy inland forest of Brazil, the labitat of M. I'nurperyensis, to 12,000 feet in the mountains of Peru and Colombia, where the brilliantly-colonred species of the Section Coccinece abound, and 14,700 feet in the Andes of Popayan, the home of M. Rucemort. 

In the more elevated regions in which Masdevallias are found, alone the limit of forest-trees and almost at the snow-line, the climate is characterised by hot sumsine and high-winds during the day, with thick fogs and a low temperature, often below the. freezing point, at night, while violent storms of rain and hail are frepuent. The specien found in these localities are terrestrial, growing in crevices of volcanic rocks and in the shade of the low shrubs which cover the hill-sides. At a lowel elevation, among the dense forests of Colombia and Ecuador, Masdevallias are very numerous, and are montly epiphytal plants, growing on the trunks and branches of trees anong thick mosses, or in hollows where vegetable soil has accunulated. The climate of the forest region in excessively damp and misty; drenching rains occur daily and cause dense fogs, which envelope the hills during the morning hours, but the temperature is warmer and more uniform than that of the higher mountains, without extremes of heat and cold, and ranging from about $48^{\circ}$ to $77^{\circ}$ Fahrenheit. The highest temperature hitherto recorded for any Masclervllia is $78^{\circ}$ to $84^{\circ}$ Fahrenheit in the low damp forests of the interior of Brazil, where M. Yauaperyensis is found.

Although the cultivation and climatic conditions of Masdevallias are now fairly well understood, it is hoped that the particulars as to altitude, temperature, and climate, given by Consul Lehmann in his notes on most of the species collected hy him, will he of use to those who wish to give their plants the treatment suited to their requirements, so far as this can be done by artificial means. In the case of many of the recenty. imported species there is a deplorable want of information upon these important points, a contrast to the careful field-notes made by botanists such as Linden, Roezl, etc. The Orchid-collectors of the present day are mostly sent out ly dealers, who, fearful lent any rival should share their profits, conceal even the name of the habitat of new species. and allow their emissaries to send home plants without any particulas an to the elevation and climatic conditions of the localities in which their discoveries were made.

The variation of many Masdevallias is consideruble, especially in the canc of . 1 . Chimara, a polymorphic plant upon which alone an entire monograph might be written. Seven or eight of its varieties were named by Professor Reichenbach as distinct iprecien. but are now, owing to the large number of intermed iate forms since introduced, achumledged in their true position. The comparatively wide geographical rauge of thispecies-extending over $\mathbf{4 0 0}$ miles in the mountains of Colombia-and the comscument differences of soil, situation, and climate, to which it must be exposed, cannot le assigned as the reason for its extreme variability, for Consul Lehman has found several rarieties growing together in the same hubitat, and all therefore slumine in similar climatic conditions. Varieties of $\boldsymbol{M}$. coccinert and $\boldsymbol{M}$. milituris are also to be found growing together in thousands in one locality, covering the hill-sides with brilliant and divers colours.

So little is known of the methods of fertilisation of Mfastecullia flowers in a wild state, or of the insects which probably effect it, that we can ouly surmine the uses of the structural peculiarities to be observed in the different species. Only the closest attention, night and day, in the natural habitat of the plints, could cheidate thin obscure subject, and although Consul Lehmann has attenpted to purste the matter during his long residence in Central and South America, and probably know more about it than any other botanist, the record of his iuvestigations has becn so long delayed that it will not be available for the present work. The mony haim on the stem of $\dot{M}$. muscosa, each tipped with a tiny drop of viscid matter, mis be supposed to act ats a protection against the incursions of crawling insects, while the sensitive and molite lip, elosed at night and open during the day, shows that the insect necessary fin the fertilisation of this flower must be a diurnal one. In the flowers of II. eleplunticrps, the strong odour of tainted meat, given out especially towards evening. may be intended to allure some kind of nocturnal fly or beetle. Honey is contaned in the nectarines at the base of the lip in many species of the Corincere Section, and probably forms an attraction to bees or moths, which, in inserting their proboscis into the deptles of the 

flower, would easily remove the pollinia aud would then transport them to the flowers of another plant. In other species the texture of the whole flower, or of some especial fart. is jucy and succulent, and possibly acts as an allurement to insects. The intermal organs of the flower of the Cocrine Section are extremely small, scarcely visible within the dece narrow sepal-tube, but the broadly-extended sepals are brilliantly coloured for the atcration of insects, which, after alighting upon them would perhaps discover the curions viscid substance to be found in the angle of the petals, and in attempting to reach thic, or in struggling to exeape from the marrow trap into which they had forced their way, must inevitably carry away the pollinia, repeating the same mancuvres in the flowers of other plants. Yany more sugrestions might be made as to the manner in which the important process of fertilisation is effected, but in the present lack of local ohervations upon the subject, no information can be given. In a wild state,

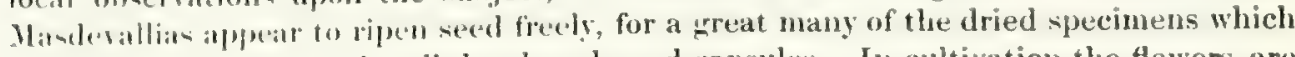
I have examined showed well-dereloped seed-eapsules. In cultivation the flowers are eavily annenable to hybidisation, but the hybrids mised by artificial means are too mumeron 10 lee figured in this work, and only at few are mentioned. Those who take an interent in them will find their merits fully set forth in the dealers' catalogues of the day.

The plauts from which my drawings were made were not chosen as fine horticulturil specineus, but may be considered, on the whole, to be of fair average size and colom: I have endeavoured to make each Plate as complete as possible, giving, in all except four. a drawing of buds more or less advanced in growth, as well as several different views of the perfect flower. In some of the Plates the colouring is not quite a) clear and bright as I could lave wished. Only a drawing direct from the flowers could give the deficate effects to be seen in nature, the grey shading of the lithograph unatidably detrating from the brilliancy of the colours laid over it. It is no doubt advantareous in botanical work or in any similar drang demanding great exactness, that the person who makes the original drawing from nature should also lithograph the Plites and indicate the colours to be used by the colourist, for, by this means, the work passes throngh fewer hands and is more likely to turn out accurate. I have therefore pursuch this method throughout the present work, and have, besides, touched up the colouring of every Plate sent out, numbering nearly 9,000. It may be noticed that the discections of iuternal parts of the flowers given in my drawings are uniform, a system interuted fo fitcilitate the comparison of the structure of one species with that of another -often renclered imposible by the want of uniformity in botanical Plates. The photographs frmm which the woodeuts were made were taken by different persons, and are, therefore, not on one scale, or meant for comparison with each other, but with the natural size of the plant as represented in the corresponding Plate. The woodcuts were executed hy Mexs. W. and .I. R. Cheshire, of 23 , Holborn Viaduet, and I would speciall! draw attention to those of M. Chimere rar. Bachiousianes and M. Houtteann, which show womlerfully delicate and careful work. It has proved impossible to give a wookcut of every species in cultivation, as was at first proposed. Some of the plants are very rure, and exist in such small pieces only, that the entire plant can be fully represented in the coloured Plate. Of the eighty cultivated species and varieties tigured, sixty-three are from the Marquess of Lothian's collection of Orchds at Newbattle Abber, and one of these, $\mathbf{H}$. Mmmmo, is a new species. Another new species, M. froctiffern, is from a drawing by Consul Lehmam and has not yet been imported alive. Wralso publisls drawings of six plants hitherto known by name only, three of them from Brazil, diseovered, drawn and described lw Senhor Rodriguez, Director of

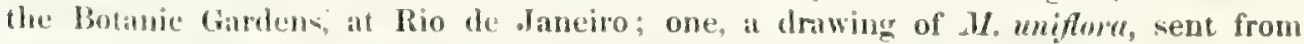
Madrid by 1)r. Mignel Colmeiro: and two dratin by Consul Lehmanu, of species not yet known in cultivatim, althongh described rears ago by Professor Reichenbach. Many of the romainder of the phants hate never before been drawn.

Although the plan of diving the Genus into Sections was originated by Professor Reichentach, he often omitted, in describing a new species, to state the Section or 
group in which he thought it should be included, and never attempted to arrange the entire series of groups in any systematic order. This can, perhaps, hardly be done until a wider kuowledge of the Genus is attained, and I have, therefore, for convenience, numbered the Sections and placed them and the species contained in them in alphabetical order. The index refers to the number and name of the Section in which wach species will be found. In the case of those plants of which it is impossible, from the original description, to ascertain the aftinities, a list is given on a separate page, and they are referred to in the index under "Section indeterminate." The names of thume species now excluded from the Genus Masdevallin are also mentioned on a separate page, and are, in the index, followed by the name of the Genus in which they have bern placed. Much doubt and uncertainty about these and other species will be set at rest only when Professor Reichenbach's vast collections of dried plants, drawings atud uotes, come to light in the Vienna Museum, where, according to the extrordinary couditions of his will, they must remain untouched for 25 years after the date of his death, which took place in 1889. Until this period has elapsed, therefore, all arrangements of Sections, and determinations of species or varieties, must he madc with renerve and regarded as temporary and uncertain.

Many interesting species will be added to the Genus when Consul Lehmann publishes his large series of drawings, made in the natural habitat of the plants. It was originally proposed that more of his drawings should be included in the present "ork, but many of those lent to me by him for that purpose, although in themselves excellent, were seut without dissections, names, notes, or descriptions, and were, therefore, useless for publication. It is only possible to indicate upon the map a very few of the places mentioned in his notes, many of them heime small remote towns and viliages, or minor mountain-peaks and valleys in the vast Cordilleras of the Andes.

To the numerous frieuds whose assistance has enabled me to accomplish this work, I must again express sincere and grateful thanks, and in addition to those mentioned in the preface I wish to thank the member of the staff' of the Royal Herbarium at Kew, who have given me their help, as well as Mr. F. Sander and Mr. R. .T. Measures, who have supplied me with information and specimens. For the loan of an excellent collece tion of dried plants, as well as for living specimens, I am indebted to Mon-ieur Lugine Autran, of the Boissier Herbarium at Clambésy, Genevd. In conclusion. I may remarh that in carrying out the work of this book, I have spared no pains, and have done my best in every way to ohtain accumte information and drawings althongh, being weithel y trained artist nor botanist, I have felt myself hardly qualified for the undertaking.

BELTON,

Luaver, 1896. 



\section{SECIION I.}

\section{AMANDAE Rchb. f.}

Tll1sinection contans five species in cultivation, and several others known only as dried specimens. It was founded by Reichenbach upon $\boldsymbol{H}$. Amanda, a plant discovered by Warncewicz in 1853, near Ocaña, and more recently wet with by other collecetors in different parts of Colombia and Antioquia. I can hear of no living -pecimcon of this phat. All the species in the section Amandre are much alike in outnarl appearance, as well as in intermal structure. The stems of all produce several small fiowers. the wings or ridges upon the ovary are serrated, and the petals are toothed upon both margins.

5 species tigured:

Mandevallia ablureviata Relsb. f: caloptera Rehl). t: $(=\mathrm{M}$. biflorr Regel $)$ melanopus Rehb. f. pachyura Rehb. f. polysticta Rehlof:

\section{Not in cultiration:}

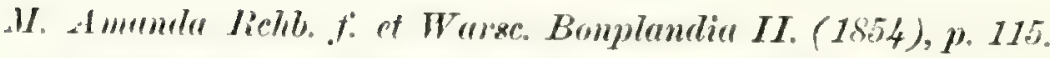
"muchate lichb. f. Otia. Bot. Hamb. (1878), p. 1\%. culopterncarpa Iichb. f. Flow (Singer) 1886, \%. 560. Gustrui lichb. f: Grued. Chron. 1875, pt. I., p. 461. Lehmmmi lichb. f: Grud. Chron. 1877, pt. II., p. 38. wielens lichl. f. Otire. Bot. Homb. (1878), p. 13.

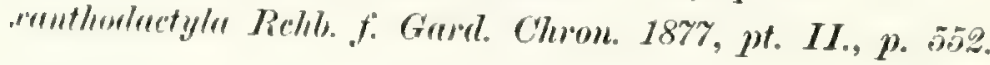





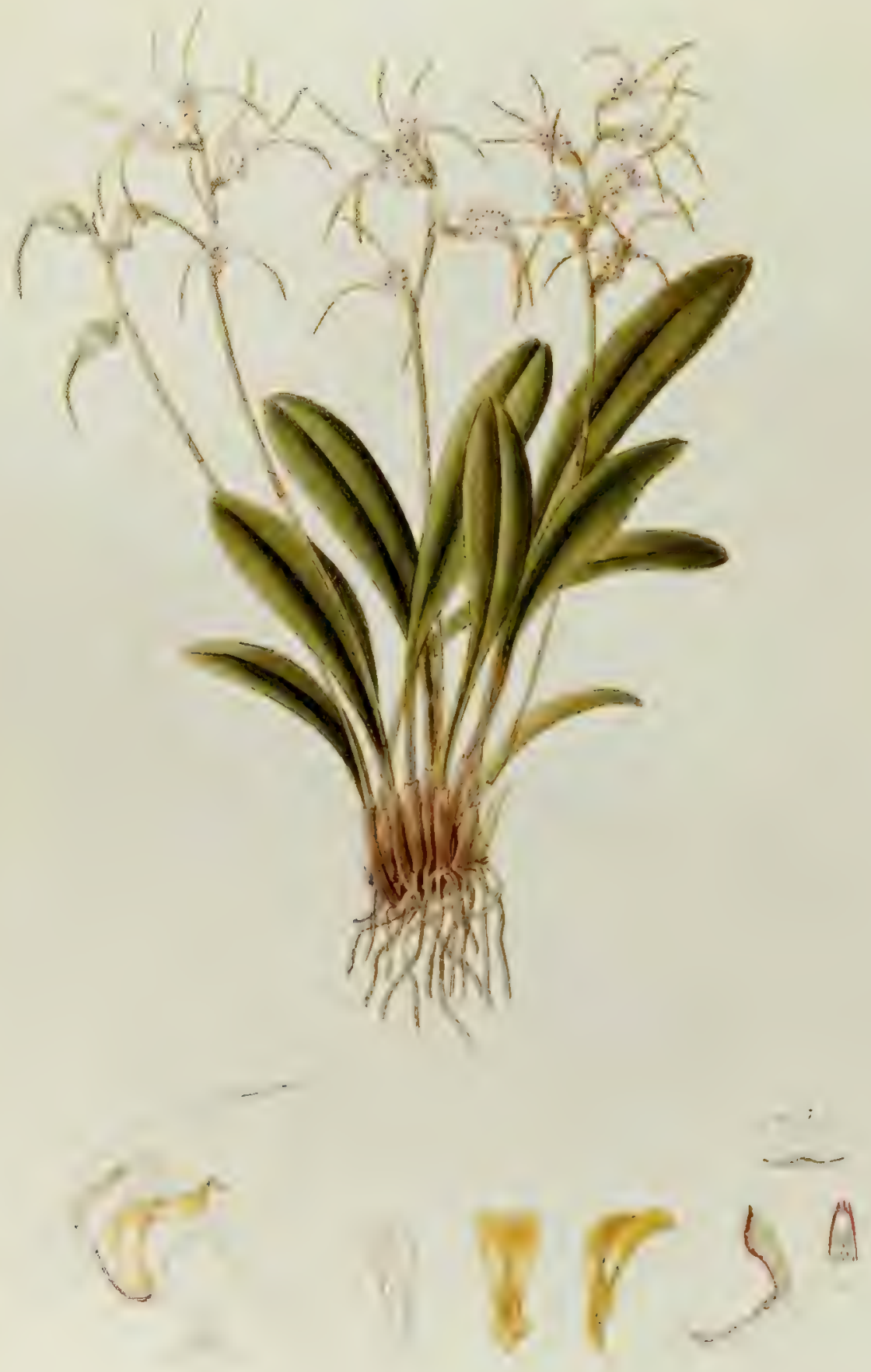


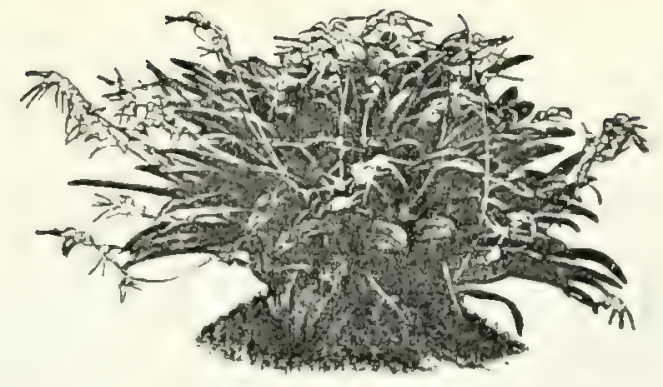

\section{MASDEVALLIA ABBREVIATA Rchb. f.}

Mampevalua abbreviata Rchb. f. Gard. Chron. 1878, pt. II., p. 106 ; 1881, pt. II., p. 236 ; Bot. Mag.

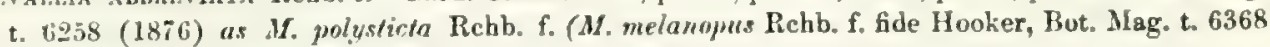
(1878) under 1\%. polysticta); Orchidophile (Godefroy) vol. 1. (1881-3), p. 83.

Leaf 5 or 6 inches long, oblong-lanceolate, apex tridenticulate, bright green, narrowing below into a slender grooved petiole, shenthed at the base.

Peduncle 6 or 7 inches long, terete, slender, ascending from within a sheath at the base of the petiole, green, many-fiowered; flowering hracts about $\frac{1}{1}$ inch long, shenthing the pedicel and the base of the orary, brownish.

Ovary $\frac{1}{8}$ inch long, triangular, with six crenate wings, pale green.

Sepals all cohering for about $\frac{1}{4}$ incl, forming a rounded tube, gibbous below, free portions oratetriangular for about $\frac{s}{10}$ inch, 3-nerved, margins sermte, white, more or less spotted with pinkish-crimson, and terminating in slender terete tails, bright yellow tipped with orange.

Petals a little more than $\frac{1}{8}$ inch long, linear at the base, obcordate, apiculate, margins sharply serrated, with a flesly angled keel on the anterior margin, pure white.

Lip longer than the petals, grooved at the base and united to the cursed foot of the column by a flexilhe hinge, lateral lobes oblong, narrowing towards the central lobe, with two longitudinal keels, apex trilobed, pale yellow.

Column a little shorter than the petals, green, with crimson apex and wings and a few spots, foot white with crimson spots, apex sharply denticulate.

A LTHOUGH Profesior Reichenbach's fint description of M. abbrevinta was not published until 1878, the plant was probably known and cultivated in Europe for some years previously, in perhaps more than one variety, and under the name of 1I. melumoy"s. So record of its habitat was given by Bruchmüller or Roezl, but there secms no doubt that one of these collectors discovered it in North Peru. Reichenbach suggests that it is perhaps a hybrid between $\boldsymbol{M}$. polysticta and $\boldsymbol{M}$. melanopus, and states also that there is "a nearly unspotted variety." It appears, however, to be a true species, and probably its extreme variability helps to account for the confusion that exists between it and $M$. melmopus, although it never approaches the very rare and distinet form of that speeies figured in the present work.

The Plate published in the Botanical Magazine in 1876 (t. 6258) as $\boldsymbol{A}$. polysticta was afterwards supposed (Bot. Mag. t. 6368, 1878) by Sir Joseph Hooker to be 11. melcnopus, but in the Royal Herbarium at $\mathrm{Kew}$ there is a letter from Professor Reichenbach, attached to dried specimens of $M$. "ubbreviata, in which he says: "The

Explanntion of Plate, drawn from a plant at Newbattle Abley:

Fig. 1, petal, lip, and column, in natural position; $-1 \mathrm{n}$, section of ovary ; -2 , petal, inner sjde;3 , lip, front view ; $-3 \mathrm{a}$, lip, side view ; -4 , column; $-4 a$, apex of column; ull énlarged; -5 , apex and section of leaf, nutueral size. 


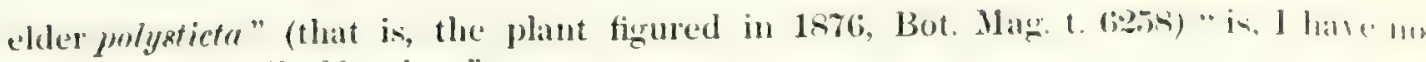
doubt, what I call abbreviatr."

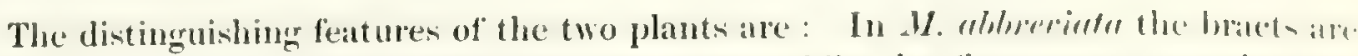

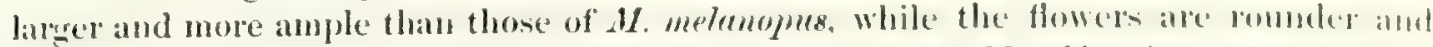

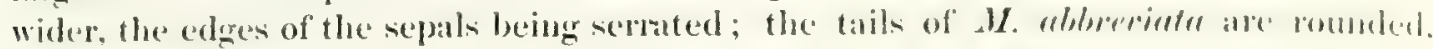
while those of $\boldsymbol{M}$. melemoyms are flat; to these chatacteristice maty be added the remarkable one-sided growth of the flowers of 11 . melamoms, specially montioned ln

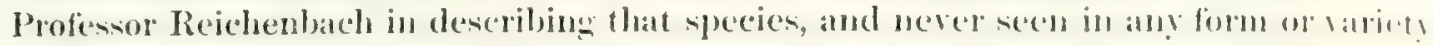

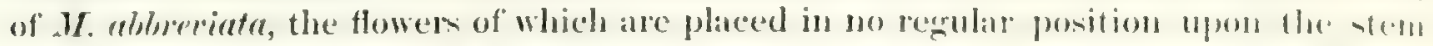
The internal oreans, also, of $M$. abberemente as will be secen by comparing the fwo Ilatepublished in the present work, differ from those of $\boldsymbol{M}$. melomenus hoth in structure and colouring.

It is curious that the name abberinte seems to have entirels disiplenedred fiom moncollections, the name melnnopms being substituted for every form and virie?! if

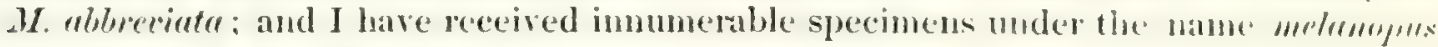
which were in fact abbrerintu.

The plant from which the accompanying drawing was taken hav existed in the collection of the Marquess of Lothian at Newbattle Abbey since 1 szo muder the Ham. of $M$. ablerevate, and is probably one of the few which remanin, competly named, of the original importation from Peru by Mons. Ortgies, of Zürich. 



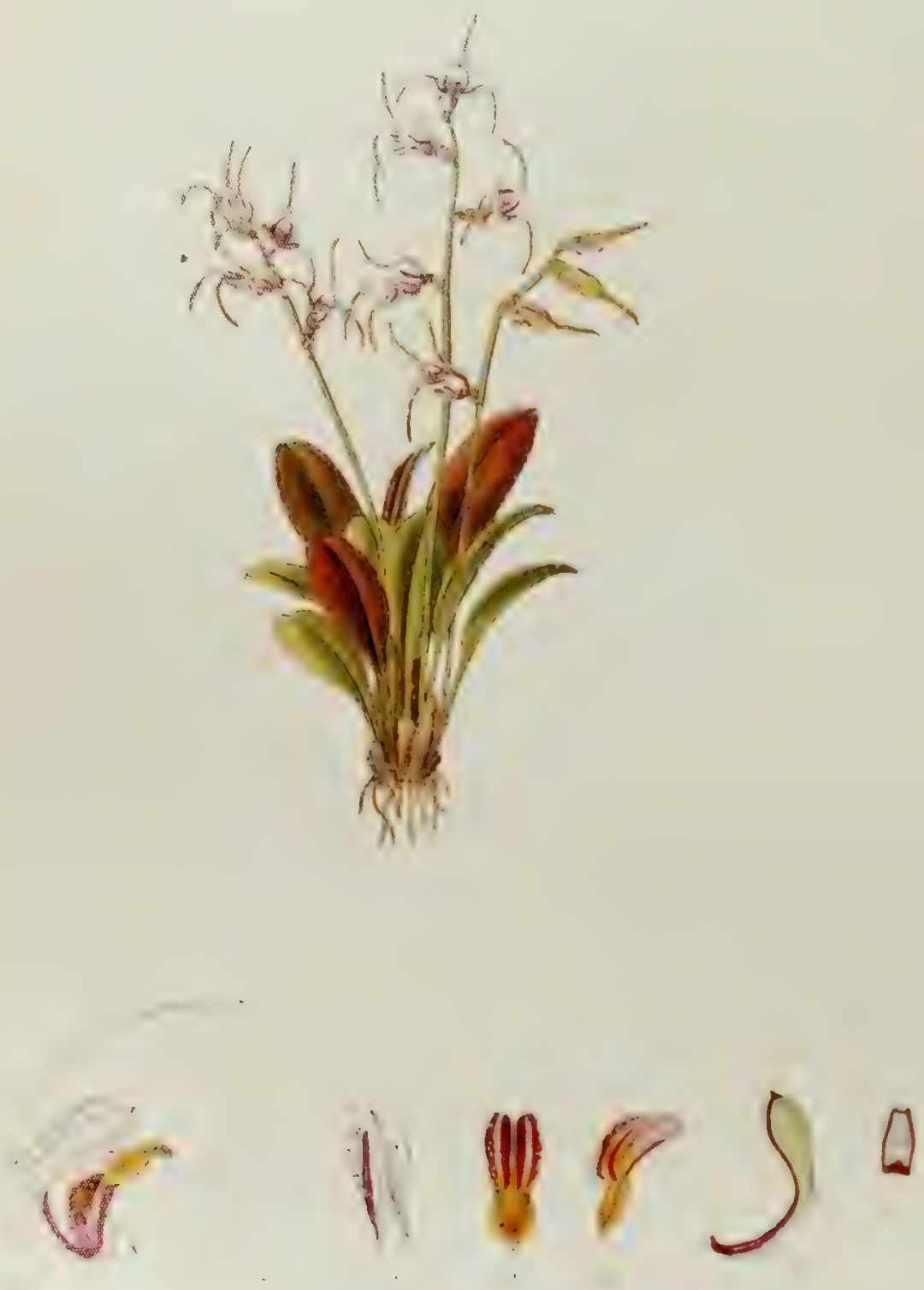


\section{MASDEVALLIA CALOPTERA Rchb. f.}

Manmalida Caloztera Rchb.f. Gard. Chron. 1874, pt. I., p. 338 (nonen tantum); pt. II., p. 322 ; 1875 , pt. II., p. 290 ; 1878 , pt. I., p. 104 ; 1881, pt. II., p. 236 ; Illustr. Hort. XXI. (1874), p. 60.

I. biforu. Regel in Gartenfura vol. I. (1891), t. 1341, fig. 2.

lenf about 3 inches long, oblong-ovate, tridenticulate, carinate, narrowing below into a slender groovel petiole, sheatlied at the base, bright green, the older leaves tinged with rust red.

l'eduncle 4 or 5 inches long, terete, slender, anscending from within a sheath at the base of the petiole, many-fiowered, with sheathing hracts, pale green; Howering bracts minute, apiculate, dull green.

Oxary \& inch long, triangular, with six crenate wings, almost covered by the bract, green spotted with crimson.

Sepals cohering for nearly $\frac{1}{4}$ inch, forming a narrow tube, gibbous below; dorsal sepal roundly triancular, cucullate, carinate at the back, margins minutely serrate; lateral sepals oblong, margins recurved: all white, with crimson streaks, 3-nerved, terminating in slender tails nearly inch long, orange-vellow.

Petals inch long, ohlong, acuminate, margins rounded and denticulate, white, with one prominent crimson keel near the anterior margin.

Lip a little longer than the petals, grooved at the base and united to the curved foot of the column by a flexible hinge, with two oblong lateral lobes, and two longitudinal keels terminaring in a rounded central cushion, apex slightly recurred, trilobed, yellow, with longitudinal crimson lines and spots, apex orange-yellow.

Column a little shorter than the petals, winged, apex bidentate, pale green, the foot and wings crimson.

MASDEVALLIA CALOPTERA was discovered by Roezl in the Northern Andes of Peru, crrowing in thick masses mixed with plants of $M$. polysticta and 11. molnumus. This remarkable proxinity of numerous species of one section is again noticed by Consul Lehmann under $\boldsymbol{M}$. pachyura, and may perhaps account for the origin of varieties and natural hybrids, some of which have received specific names. Roczl's dried specimens of $\boldsymbol{M}$. caloptern were named and described by Professor Reichenbach in 1874 , and it was not until the last few years that living plants were imported. These were distributed under incorrect names, as $M$. pachyura and $M$. bifiora, the latter name being published by Regel in his Gartenflora, with a coloured figure of a small specimen of $\boldsymbol{H}$. coloptera.

A note from Consul Lehmann upon $M$. ablrevinta-received too late for publication with our Plate of that species-may be inserted here. He mentions several localities in which he also found $\boldsymbol{M}$. pulystict and $\boldsymbol{M}$. melanopus, the identical species found by Roezl growing with $M$. caloptera. The region is evidently the same as that explored by Roezl during his discoveries.

Mnsterallia abbreviata is confined to a comparatively small area in Northern Peru and Southern Ecuadur. at an elevation of 1,800 to 2,000 mitres ( 5,850 to 7,150 feet). It grows on trees, orergrown with mosers, lichens and epiphytes, in the thick damp woods which surround the Mountains of Ambocas Catacocha, Gonzanami, Cariamanga, Hutiana, and Sabiango. These mountain-chains branch off partly from the Huaira-urcu and partly from the Nudo de Saranilla, in the province of Loja, gradually sloping in a suth -westerly direction towards the dreary deserts of Northern Peru. The climate of this region is damp and forgy throughout almost the whole year. Eren during the dry season, which only lasts from the beginning of July to the end of September, beary mists envelope the forests every morning and evening. The annual mean temperature ranges between $15^{\circ} .5$ and $17^{\circ}$ centigrade (about $59^{\circ}$ to $63^{\circ}$ Fahrenheit).

Explanation of Plate, drawn from specimens kent by Mr. Sidney Courtauld and Mr. F. W. Moore:

Fig. 1, pretal, lip, and column, in natural position;-1a, section of ovary; -2 , petal ; -3 , lip, front view :-3a, lip, side riew; 4, column; 4n, apex of column; all enlarged. 
. 



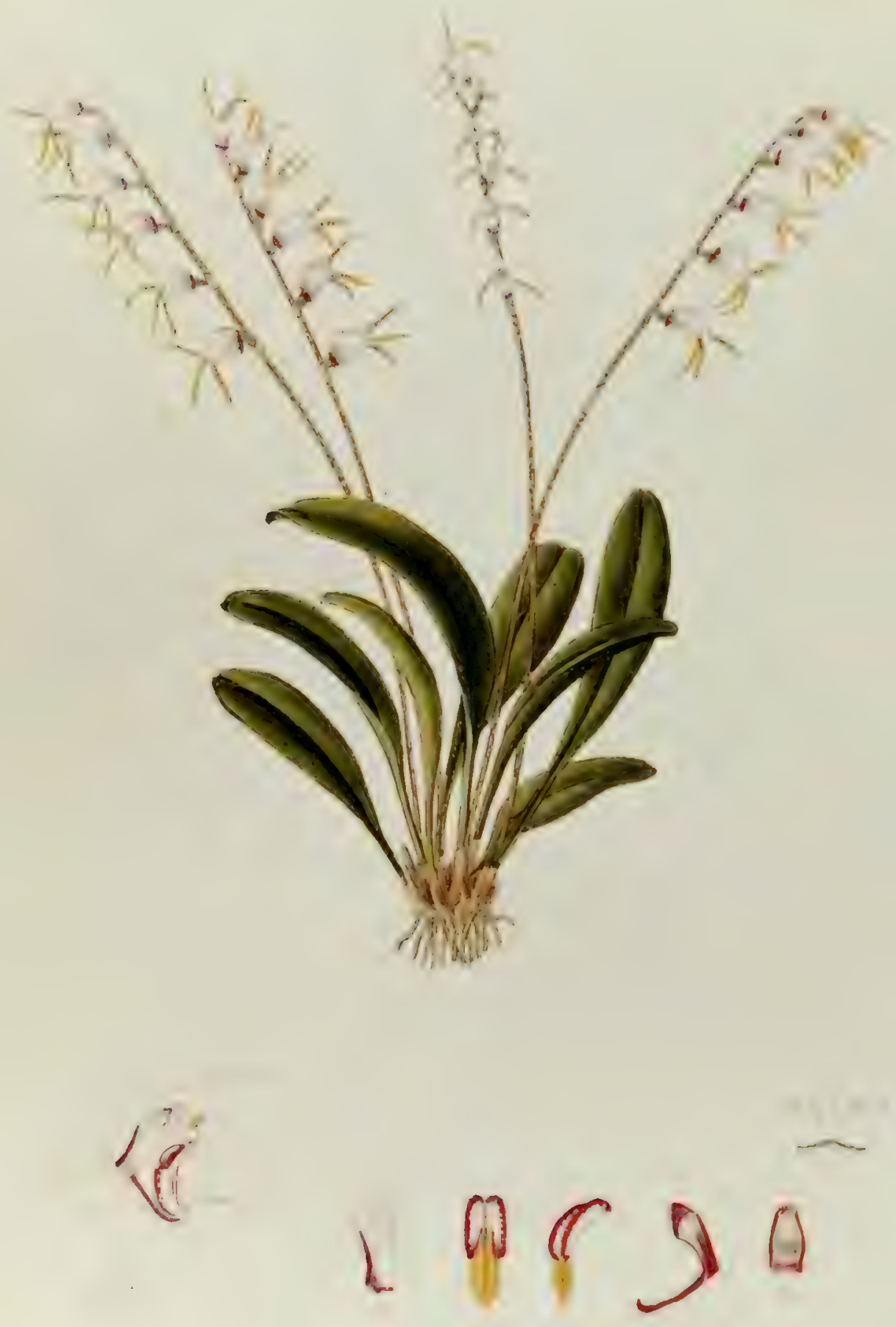



The most noticeable characteristic of this plant is, perhaps, that, as stated by Professor Reichenbach, the flowers are " all directed to one side." In dried specimens. the small spots are less visible, while the dark colour at the base of the flowers becomes more apparent, producing the blackish stain which suggested the name molmopm, or "black-foot"

I am indebted to Mr. Moore for numerous examples of these flowers, as well as for a piece of his plant, at that time probably the only one of the species in the British Isles.

\section{Note by Consul Lehmann:}

The babitat of Masdevallia melanopus is in Ecuador and North Peru, where it grows on trees in dense woods at an eleration of 2,400 to 2,700 metres ( 7,800 to 8,775 feet). I have found it on the Curdillerit de Amboca, near the rillages of Cisne and Chuquiribamba, in the Prorince of Loja, Ecuador. Also near Cariamanga, Hutiana and Sosoranga, in the mountrins of Loja, and of Piura in Perm. It Howers in October and November.

The climate of this region is damp and foggy during the greater part of the yenr. During the dr: season, which lasts only from the end of July to the first few days of October, parching winds sweep, uver the mountains, and for sereral bours of the day the sun shines from a cloudless sky, causing many of the. plants to shrivel and die off. The snnual mean temperature ranges between $14^{\circ}$ and $16^{\circ}$ Centigrade (about $57^{\circ}$ to $61^{\circ}$ Falurenheit). 





\section{MASDEVALLIA PACHYURA Rchb. f.}

Vasimatilu pacarva Rehb. f. Gard. Chron. 1874, pt. II., p. 322 ; 1881, pt. II., p. 336 ; Linnea XI.I. (1877), p. 12.

Leat 5 or finches fong and nearly 1 inch wide, oral-oblong, narrowing below into a slender grouved petiole sheathed at the hase, apex tridenticulate, bright green, petiole dull purple.

l'feluncle about 6 inches long, terete, slender, ascending from the base of the petiole, with three or four flowers at intervals of about half-an-inch, pale green, with very minute crimson spots on the upper lalf, and two slienthing bracts below; flowering bracts minute, apiculate, membranous, pale brownish. green.

Orary $\frac{1}{2}$ inch long, triangular, with six crenate wings, dull greeo spotted with dark crimson.

Sepals: dorsal sepal united to the lateral sepals for about $7^{3}$ inch, forming a wide tube, gibbous below. 3-nerved, orate, cucullate, margins slightly toothed, pale whitish yellow, semi-transparent, covered with small transverse reddisb-crimson spots, the central nerve carinate, green, terminating in a slender yellow tail nearly $\frac{1}{2}$ inch long; lateral sepals cohering for about inch, oblong, 3-nerved, margins reflexed, free portion about $\frac{1}{4}$ inch long, yellow, with reddish-crimson spots and a dark crimson central streak, base dark crimson, central nerves strongly carinate on the outer surface, tapering into orangevellow tails about 3 inch long.

Petals about $\Varangle$ inch lung, obcordate, acuminate, the margins strongly serrate, with two lateral keels, pale yellow.

Lij a litte longer than the petals, united to the foot of the column by a flexible hinge, pandurate, with two lateral Jobes terminating in short hech, apex rounded, pale yellow corered with minute red spots.

Columm equalling the petals, winged, apex minutely denticulete, greenish-yellow with crimson wings and apex, and a few minute crimson spots on the inner surface. The plant represented in the accompanying Plate was recently imported by Consul Lehmann for Mr. James O'Brien, to whose kinduess I am indebted for the opportunity of drawing the first flowers of this species ever seen in cultivation.

Consul Lehmann sends me the following note:

W. purhumra las a comparstively small distribution along the western slopes of the Western Andes of Ecuador. from the Mountains of Zaruma in $3^{\circ} 30^{\prime} \mathrm{S}$. lat., to the restern slopes of Chinbornzo in $1^{c}$ S. lat.. at an elevation of 1,700 to 2,300 mitres $(5,525$ to 7,475 fect). It is abundant in one small district inly, viz., around Cayandelet on the road from Puente de Chimbo to Sibambe, and above lallatanera on the road from l'uente de Chimbo to Cajabamba. In all other localities it is very rare. It usually zrows on trees in very damp thick woods, but occasionally I hare found it growing upon walls of rock, ns at Gualashay on the roal to Guaranda. It flowers in March and April, and sometimes also in November. The mean temperature of its habitat ranges from $15^{\circ}$ to $18^{\circ}$ Centigrade $\left(59^{\circ}\right.$ to $64^{\circ} .4$ Fahrenbeit).

The plants of $M$, puchyura which I sent to Mr. O'Brien under the nawe of $M$. tridens I had never scen in flower, and only guessed them to be the latter. Many species of this section (.Amanda Rchb. f.) grow mixed tugether-for instance, M. Lehmanni, M. melanopus, M. anachale, M. abbreviata,. 11. parlunura and 11 . tridens-and as the leaves of all are very much alike, it is a difficult matter to distinguish one from another when out of flower.

Fxplanation of Plate, drawn from Mr. O'Brien's plant:

Fig. 1, petal, lip, and column, in natural position;-1a, section of ovary ;-2, petal, inner side;3. lip ; - 3at, side of lip;-4, column ; - 4a, spex of column; all enlarged. 




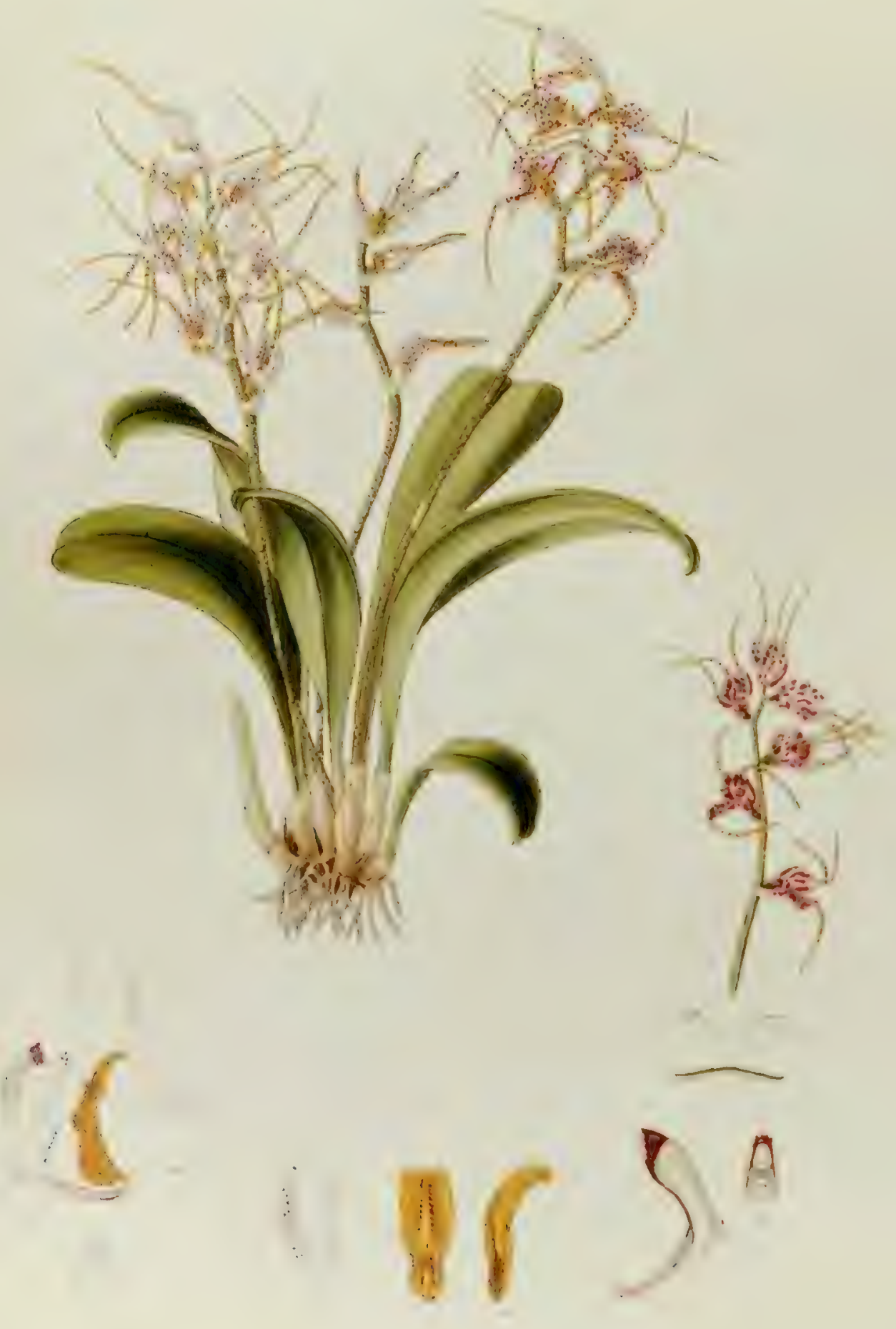




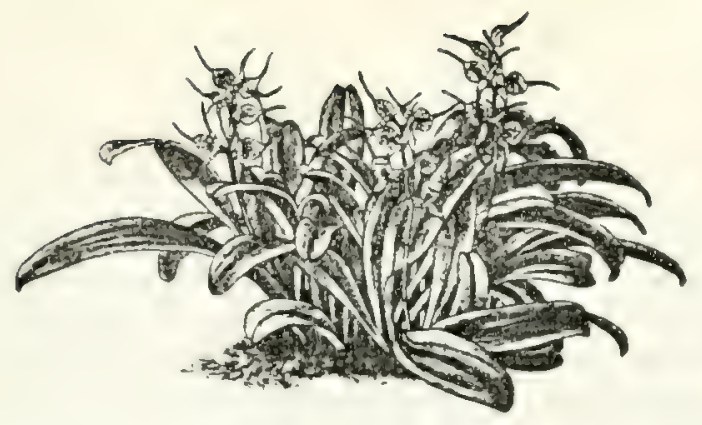

\section{MASDEVALLIA POLYSTICTA Rehb. f.}

Mastevallia rolrsticta Rehb. f. Gard. Chron. 1874, pt. I., p. 338 (nomen nudum); pt. II., p. 290 ; 187.5, pt. I.. PP. 40 and 656 , fig. $134: 1 \leqslant 81$, pt. II., p. $336 ; 1889$, pt. I., p. $179 ; 1884$, pt. I., p. 741, in sroup fig. 141 ; 1889, pt. I., p. 139; Illust. Hort. XXII. (1875), p. 41, pl. CXCIX. ; Bot. Mag. t. 636s (1S78); Gartenflora (Regrel) rol. XXV. (1876), p. 164, t. 869 ; Revue Hort. 1880, p. 250 ; Orchidophile (Godefroy) vol. I. (1881), p. 271. rar. crassicaudata; 1888, p. 283 ; Veitch Manual Orch. pt. T. (1889), p. 58.

Leaf about 5 inches long, and $I$ inch wide, oblong-lanceolate, apex tridenticulate, often much recurved, margins reflexed, narrowing helow into a grooved petiole, sheathed at the base, bright green.

Peduncle 8 or 10 inches long, many-flowered, terete, ascending from a joint at the base of the petiole, dull green, with minute reddish spots; pedicels scarcely incb long, terete, curved; bracts $\frac{1}{4}$ inch long, membranous, orate, apiculate, concealing the pedicels and the base of the orary, pale green.

Oxary $\frac{1}{k}$ inch long, with six crenate wings, pale green.

Sepals: dorsal sepal united to the lateral sepals for about $\frac{1}{6}$ inch, furming a wide tube, gibbous beneati. free purtion ovate for $\aleph_{\aleph}$ inch, 3-nerved, cucullite ; lateral sepals cohering for about $\frac{9}{8}$ inch, linearlanceolate, 3.nerved, marcins reflexed; all white, with numerous small crimson or brownish-red spots, the inner surface closcly set with translucent white hairs, the lateral sepals having a broad central streak of orange-yellow; all terminating in slender tails about $\$$ inch long, often angled and thickened towards the apex, orange-yellow, greenish at the back, with a few small crimson spots.

Petals about 1 inch long, spatbulate, margins ciliate, with a strong keel near the anterior margin, apex acute, white, with a few crimson spots along the keel.

Lip about $\frac{1}{6}$ inch long, pandurate, with two lateral lobes terminating in longitudinal keels near the apex, rich orance-vellow covered with minute crimson spots, apex reflexed, with a rounded central lobe.

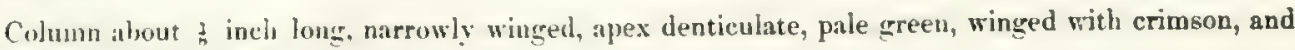
with a few crimson spots.

MASDEVALLIA POLYSTICTA was discovered by Roezl in 1874 in the Northern Andes of Peru, where it is found in great abundance, growing with $\boldsymbol{M}$. melanopus and $M$. culopterr. No detailed account of its habitat has been given.

It is apparently an extremely variable species, scarcely two plants beaing exactly similar flowers. The spots upon the sepals vary greatly in number and size, and in depth of colour, being pinkish-purple in some specimens and in others chocolate-crimson. Some plants have thick, stiff flower-stems, and others very slender stems, while the leaves of some are straight and upright, and of others much recurved. The most distinctive chancteristics of the species-in whatever form or variety-are the ample membranous bracts and the numerons white hairs within the sepals.

Explanation of I'late, drawn from a Plant at Newbattle Abbey :

Fig. 1, petal, lip, and columu, in natural position;-1a, section of ovary; -2 , petal, inner side ;3 , front of lip; - $3 a$, side-view of lip; -4 , column; $-4 a$, apex of column ; - all enlarged; -5 , apex and section of leaf, natural size; -6, dark rariety. 
$$
\text { . }
$$ 
A dark variety, figr. 6 of the aceompanying Plate, wats sent to me in February hy sir Trevor Lawrence, who informs me that it was found growing in the same mate with the ordinary variety. The spots are rich crimson-purple, suffised and very numerous, nearly covering some of the sepals, and the orange streak seen in the lateral sepals of the ordinary variety, is replaced in this specimen by erimson-purple lines. I have also received this dark variety from Mr. F. W. Moore, Glasnevin, Dublin.

Consul Lehmann sends more detailed information than any hitherto published about the habitat of this species:

Masdevallia polystictn is found in Sonthern Ecuador and Northern l'eru. It grows on treesgenerally on Heinmannius-or occasionally on rocks, in park-like woods on the Cordillera de Anbern, and in the vicinity of Gonzanamá, Cariamanga and Hutiana in the Province of Loja ; and also amumbl Huncabamba in the Province of l'iura, at an elevation of 2,000 to 2,500 mitres $(6,50040,8,125$ feet $)$. In general it occurs in great abundance, often covering the trunks and branches of trees. flue plant attaining a large size. In the Province of Luja it fowers from November until May.

In these regions there is a long rainy season, lasting from October to July, and during these month the atmosphere is nearly always saturated with mointure. The annual mean temperature rangen between $14^{\circ}$ and $16^{\circ}$ Centigrade (alout $55^{\circ}$ to $61^{\circ}$ Fahrenbeit). 



\section{COCCINEA Rchb. f.}

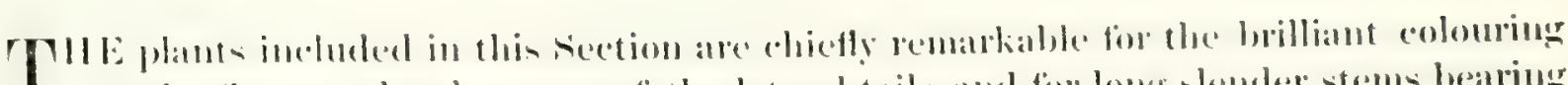
of the flowers. the shortness of the lateral tails, and for long slender stems bearing solitary flowers high abose the leaves. The petals of all are rerg much allike in shape, and have beneath the matrinal angle a curious mass of white viscid matter, the use of

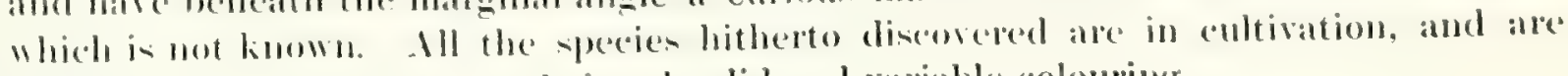
highly prized for the sike of the ir splendid and viriable colomring.

$$
\text { (i) neceies figured: }
$$

Jamelevallia amaluilis Rehls.

Barlacana Rehb. t.

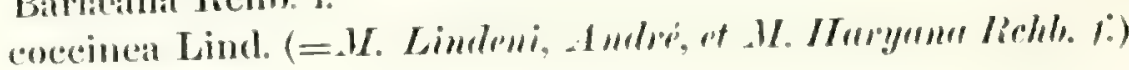
Davisii Rehb. f:

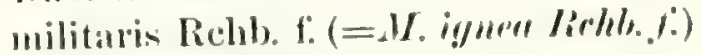

Veitchiama Relub. f: 




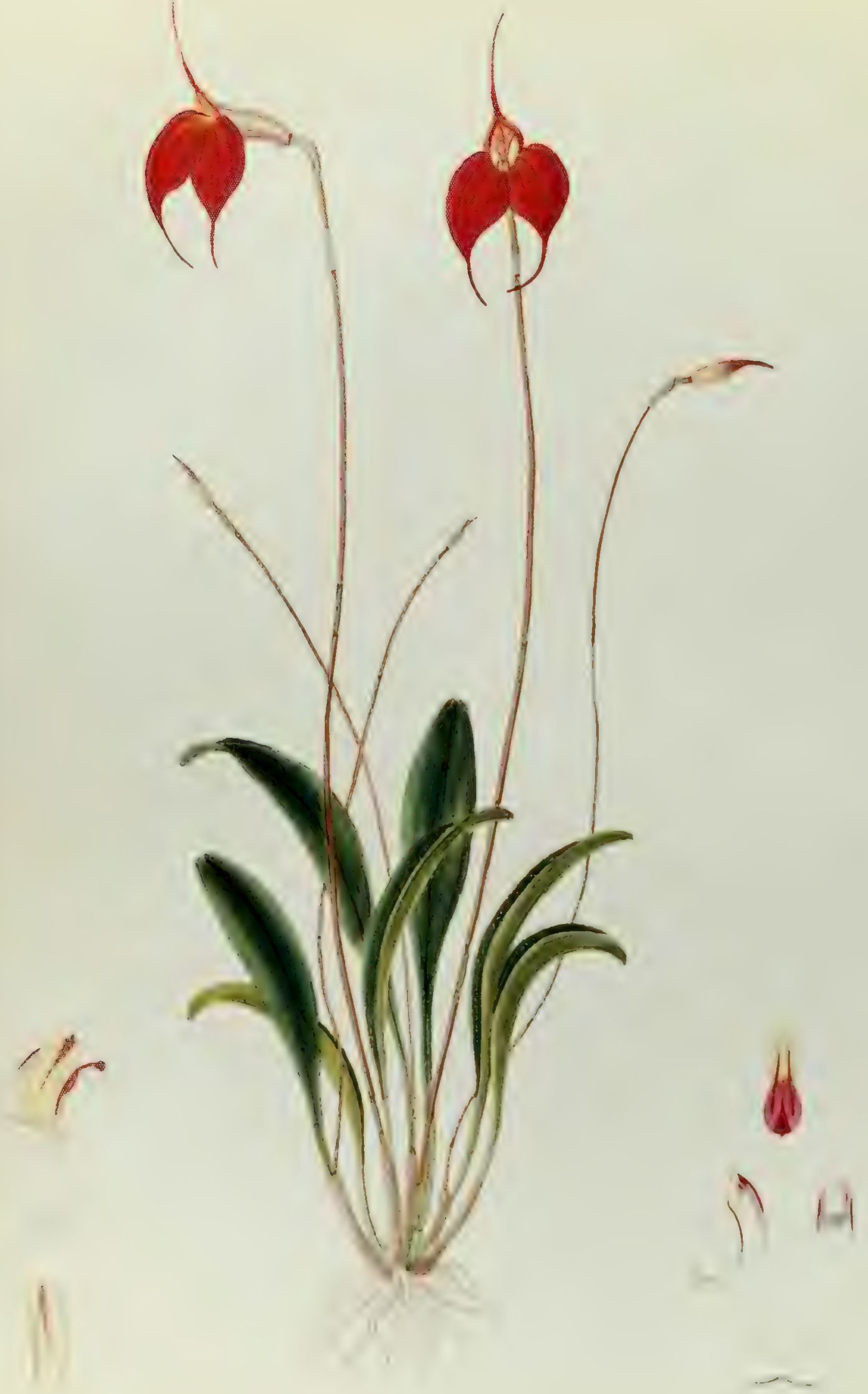




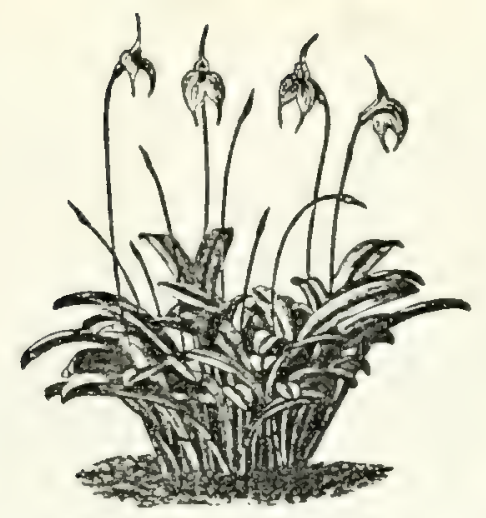

\section{MASDEVALLLA AMABLIS Rchb. f.}

Maspryales Avarusis Relab. f. Bonplandia II. (1854), p. 116 ; Walp. Ann. VI. (1861), p. 193; Belg. Hort. 1873 , 1. 354; Illustr. Hort. vol. xxi. (18it), t. 196 (var. lineata); Gard. Chron. 1881, pt. II., p. 236 .

Lenf 5 tu 7 inclues long, $\frac{1}{2}$ to 1 inch wide, oblong-lanceolate, tridenticulate, carinate, dark green, narrowing into a slender grooved petiole, shenthed at the base.

l'edumcle 10 or 12 inches long, terete, slender, ascending, 1-flowered, pale green tinged with pink, with three or four sheathing bracts, the fiowering bract about so inch long, 5 -nerved, apiculate, pale green or brownisls.

Uvary about fa inch long, curved, with three broad and three narrow rounded angles, pale green tinged with rose-pink.

Sepals: dorial sepal united to the lateral sepals for vearly one inch, forning a deep narrow tube, slishty curved, yellow shaded and nerved with rose-crimson; free portion of the dorsal sepal about $\frac{3}{8}$ incb in length, anl the same in width, ovate, 3-nerved, orange shaded with crimson, tapering into a ver: -lender tail about $1 \frac{1}{2}$ inch long, orange-red and crimson; lateral sepals cohering for about $1 \frac{1}{2}$ inch, $\frac{3}{8}$ inch wide, ovate-triangular, with is crimson nerves, brilliant red shaded with rosy crimson, velvety with lustrous microscopic hairs, trils 3 inch long, very slender, dark crimson.

Petals $\frac{1}{+}$ inch long, linear-oblong: curved, apiculate, with a prominent keel on the inner surface parallel to the anterior margin, terminating in a curved point, beneath which is a mass of colourless viscid matter; jale orange-yellow. npex crimson.

Lipl I inch long, pandurate, with two longitudinal keels, margin reflexed, apex recurved, jale orange. vellow at the hase, then rose-crimson, apex and keels dark crimson.

Columu $\frac{1}{1}$ inch long, npex minutely denticulate, very pale yellow, marked at the back and narrowly winced witl crimson.

MASDETALLIA AMABILIS was discovered by Wancewicz in the Peruvian Andes about the vear 1850, and was described by Professor Reichenbach in 1854 from driced specinchs. It was not known in cultivation until 1872, when Roezl brought living plants from the simc region, and these flowered first in 1875 , at Brussels, in the collection of . Ions. Linden. The flowers, which are faintly sweet-scented, vary much in colour, some being brilliant scarlet veined and sladed with crimson, and others uniform glowing ancthrst-crimson with the veins scarcely visible. A less beatiful variety is yellowish, shaded and strongly veined with crimson or red, and it is this form which is figured in L'Illustration Horticole for 1 fitt as M. mmbilis var. lineutu, sometimes also sold as M. amubilis var. strinta.

Foxplamation of l'late, drawn from a plant at Newhattle Abbey:

Fig. 1, lip, columm, and jetal, in natural position;-1a, section of ovary ; - 2, petal, inner side ; 3 , lip ; - + cohum ; - ta, apex of column; wll enlarged ; -5, spex and section of leaf ; valural size. 



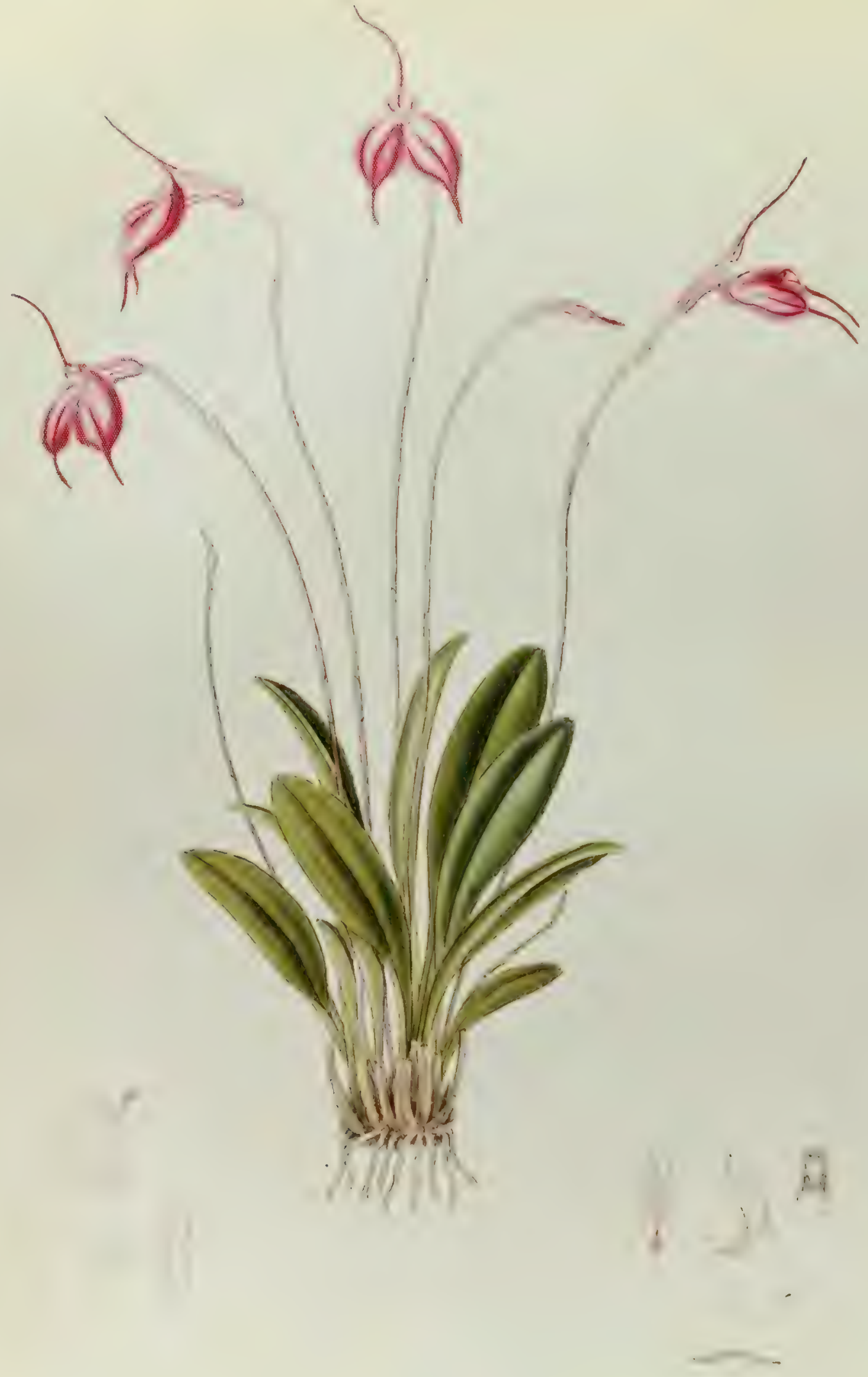




\section{MASDEVALLIA BARLÆANA Rchb. f.}

Masmevablia barlarasa Rclob. f. Gard. Chron. 1876, pt. I., p. 170; 1881, pt. II., p. 236; Belg. Hort. 1877, 1. 141; Veitch Manual (1)ch. pt. V. (1889), p. 25.

Leaf about i inches long, ovate-lanceulnte, apex tridenticulnte, bright green, narrowing below into a sender arooved pale green petiole, sheathed at the base.

Peduncle, including the pedicel, \& or !) inches long, terete, erect, slender, one-flowered, with two or three shesthing hracts, pinkivh: Howering bract nearly 3 inch long, apiculate, sheathing below, dull greenish-pink.

() sary abmut inch long. slender, with three large and three small rounded angles, dull pink.

Sicpals: dursil sepal mited to the lateral sepals for $\$$ inch, forming a narrow tube, free portion orate-triangular for about $\ddagger$ inch, 3-nerved, terminating in a slender terete tail nearly $1 \frac{1}{2}$ inch long; lateral sepals cohering for more than 1 inch, ruundly triangular, 3-nerved, terminating in slender tails about $\frac{1}{2}$ inch long ; all rose-magenta, shaded and veined with scarlet or crimson.

Petals very minute, oblong, tridentate, with an angled keel on the auterior margrin, white.

lipip searcely as long as the petals, oblong, united to the foot of the column by a flexible hinge, with two longitudinal keels, white, apex slightly reflexed, rose-pink.

Column shorter than the petals, foot much curved, apex denticulate, white, faintly tinged with pink.

$\mathrm{M}$

ASDEVALLIA BARLEANA was discovered near Cuzco, in the Andes of Peru, y Davis, while collecting for Messrs. Veitch, in 1875. It was named by Professor Reichenbach after senhor Barla, Brazilian Consul, and Director of the Natural History Museum at Nice, and the athor of several botanical works

This species is very closely allied to $\boldsymbol{M}$. mmabilis, but a glance at the Plate representing that plant will show that considerable differences exist between the two plants.

Kapplauation of Plate, drawn from a plant at Newbattle Abbey :

Fig. 1, petal. lip, and culumn, in untural position ; - 1n, section of ovary ;-2, petal, inner side ;3 , lip : -4 , column: -4 il, apex of column; all enlarged; -5 , apex and section of leaf, natural size. 




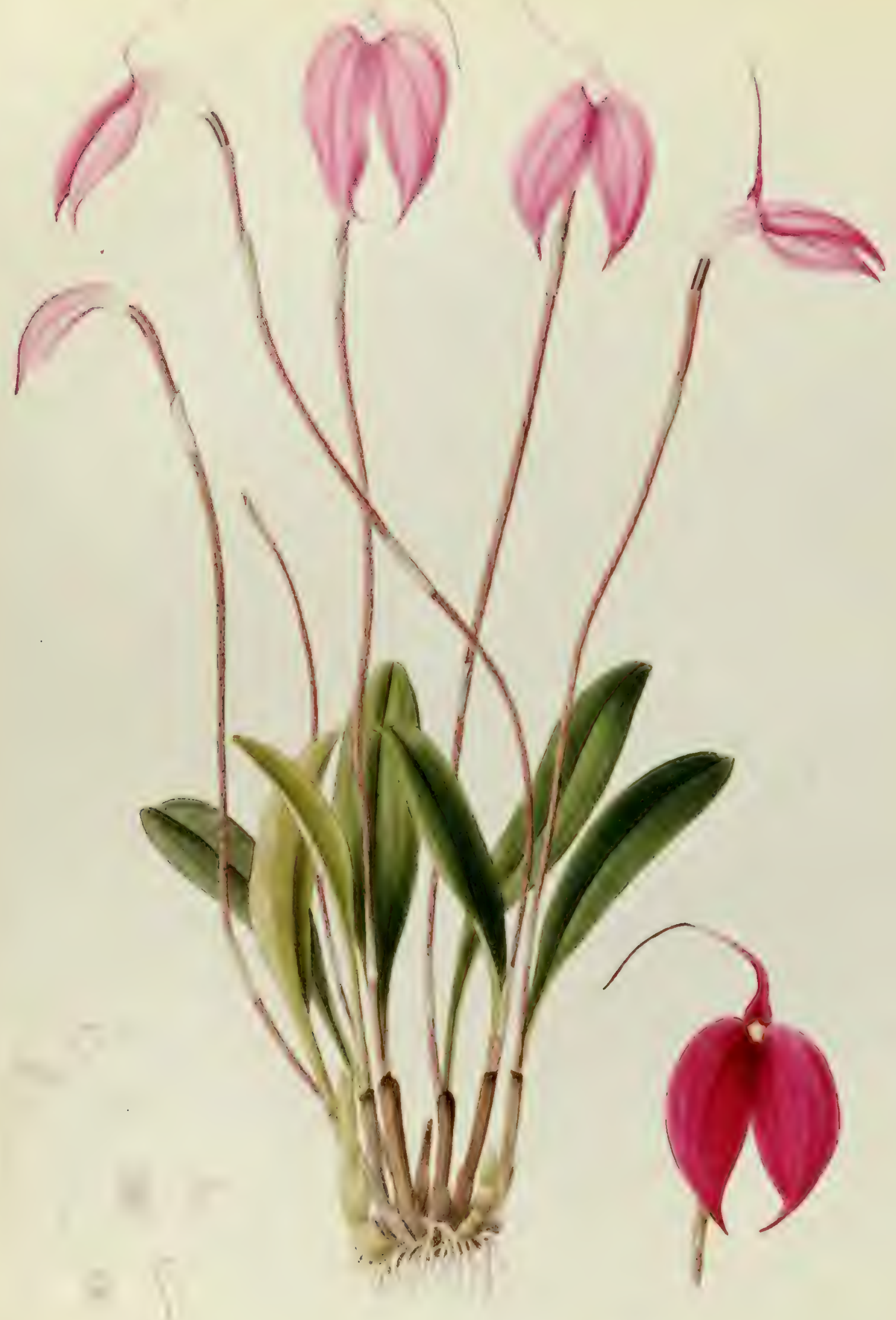




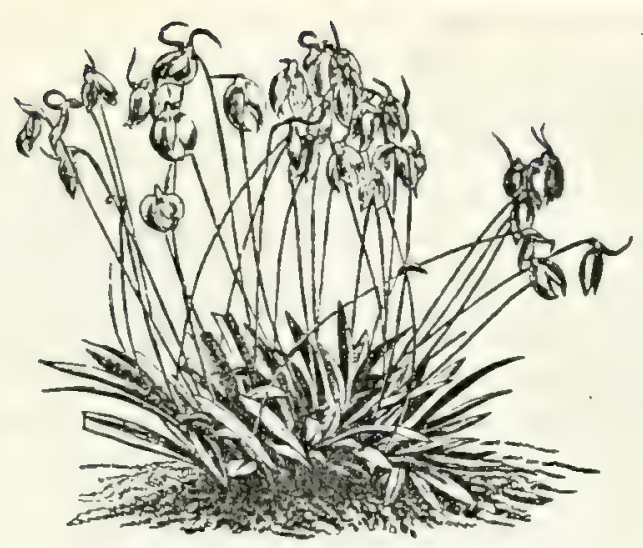

\section{MASDEVALLIA COCCINEA Lind.}

Masdevalita coccinea Lind. Mgs. ; Lindl. Orch. Lind. (1846), p. 5 ; Rehb. f. Bonplandia II. (1854), Pp. 115 and 283 ; Xen. Orch. I. (1858), p. 197, t. 74 ; Walp. Ann. VI. (1861), p. 192; Gard. Cliron. 1868 , p. 75 , with fig.; 1880 , pt. I., p. 490 ; 1881 , pt. II., p. 236 , fig $49 ; 1884$, pt. I., p. 736, fig. 138 ; 1889, pt. II.. 1. 239 ; Belg. Hort. 1873, p. 356 ; Garden 1878, pt. I., p. 102 ; Floral Mng. 1880 , pl. 410, no. 2; Veitch Manual Oreh. pt. V. (1889), p. 33.

M. Lindeni Indiré, Illustr. Hurt. XYII. (1870), p. 226, pl. XLII.; XXI. (1874), p. 101 ; Bot. Mag. t. 5990 (18ĩ2) ; Floral Mag. 1\$72, pl. 28; 1880, pl. 410, no. 1; Florist and Pomol. 1873, p. 169, with col. fig. ; Belg. Hort. 1873 , p. 358 ; Gard. Chron. 1874 , pt. I., p. 38ă, fig. 85; 1881, pt. UI., p. 336, fig. 62 ; 1854, pt. I., pp. 736 and 741 ; ()rchids, Jennings, pl. XVII. (1875); Garden 1876, pt. Il., p. $240 ; 1878$, pt. I., p. 102 ; Orchidophile (Godefroy) vol. I. (1881), p. 407 ; Lindenia I. (1885), p. 73 , pl. XXXIY.; var. grandiflora.

M. Lindeni var. Harryana André Illustr. Hort. XX. (1873), p. 16ī, pl. CXLII.

M. Harryana Rehb. f. Gard. Chron. 1871, p. 1421 ; 1879, pt. Is, p. 716, var. laeta Rehb. f. ; 1881, pt. II., p. 305 ; 1884, pt. I., pl. 114 and 741 , in group fig. 141 ; Florist and Pomol. 1873, p. 169, with col. tig. ; Belg. Hort. 1873, p. 353, pl. XXI.; Flores des Serres XXI. (1875), p. 155, t. 2250 ; Garden 18i8, pt. I., p. 102 ; Flonal Mag. 1880, pl. 410, no. 3 ; Orch. Album (Wan. et Will.) I. (1882), pl. 24, var. rerulescens; III. (1884), pl. 105, var. atrosanguinea; $\mathrm{pl} .110$, var. miniala; V. (1886), pl. 224, var. Atmeniaca; VIII. (1889), pl. 344, var. decora; Reichenbachia ser. 2, vol. I. t. 26 (1891), var. splendens.

Leaf 8 or 9 inches long, oblong-lanceolate, apex tridenticulate, dark green, narrowing below into § slender grooved petiole, sheathed at the base.

Peduncle 12 or 15 inches long, terete, slender, ascending from a joint near the base of the petiole, witl, two or three shenthing hracts, dull green, tinged with crimson or red-brown; fiowering bract nearly 1 inch long, oblong.ovate, shentling below, carinate, apiculate, dull pale green, with a minute rudimentary hud within at the base.

()ary 3 inch long, curved, with six rounded angles, shining, brownish-green.

Sepals: dorsal sepal united to the lateral sepals for about 3 inch, forming a curved narrow tube, white at the base, free portion triangular-orate for 3 inch, 3-nerved, narrowing into a slender recurved tail, 13 or 2 inches long, pale mave, tail darker, crimson towards the apex; lateral sepals colering for ahout 1 inch, free portions oblong-orate for $1 \frac{1}{2}$ inch, 5-nerved, terminating in suort blunt tails, brilliant magenta-mauve, with rosy crimson nerves, tails darker.

Petals a inch long, linear-oblong, keeled and angled on the anterior uargin, pure white, faintly nerved with rose.

Lip 3 inch long, oblong-pandurate, with two longitudinal keels, thickened and grooved at the base, margin recursed, white, tinged with ruse-pinh, apex sharply recurved, rose-crimson, sometimes tinged with yellow.

Column about + inch long, very narrowly winged, apex minutel! denticulate, white, sometimes winged and tipped with rose-crimson.

Explanation of Plate, draws from a plant at Newbattle Abbey:

Fig. 1, petal, lip, and column, in natural position;-1a, section of ovary ; - 2, petal, inner side ;3 , lip ; - a a, apex of lip; -4 , column; $-4 \mathrm{a}$, apex of column; -5 , column from another specimen; all enlurged ; - (i, apex and section of leaf ; -7 , var. Harryana; nafurul size. 

ASDEVALLIA COC'CINEA was discovered about the year 184 by Linden, flovering in April on the scutlern slones of the mountains near Pamplona, in the Province of Santander, Colombia, at an elevation of 9,500 feet. In this region the mean temperature is $52^{\circ}$ Fahrenheit. The first living plant imported into Europe was a small piece sent to Ghent in $\mathbf{1 8 6 7}$ by Gustar Wallis, among a quantity of other Orchids from Colombia. This little unknown plant was treated with great care, and when it flowered in 1870, it was named Masderallia Limdeni, and deseribed as a new species by Mons. Andre in the "Illustration Horticole." From time to time varieties of $M$. coccinel were imported from different elevations and localities in the Eastern Cordilleras of Colombia, until it became universally known and cultivated as the most brilliant and variable species of the genus. In 1871 the first of these varieties, sent to Mr. Harry Veitch from Sogramosa by the collector Chesterton, received the specific name of Harmana from Profestor Reichenbach, although, from the fact that he published no Latin description of the flower, he does not appear to have really considered it a distinct species.

Some idea of the immense abundance and variability of $\boldsymbol{M}$. cuccinea is afforded by the account published in Mr. Veitch's "Manual of Orchidaceous Plants," from which I lave permission to make extracts:-Its principal locality is on the eastern Cordillera, between Sogamosa and Concepcion, where its vertical range is 7,000-10,000 feet ; is particularly abundant on that part of the Cordillera ealled the Sierra Nevada de Clita. where it spreads in uninterrupted masses for miles, covering acres upon acres of the uplaud slopes, and growing in the partial shade afforded by low shrubs. When in bloom these masses of plants present a most striking sight, not only by the dazzling brillianey of the colours of their flowers, but also ly their astonishing variety. There is scarcely a shade of colour, from deep rich crimson-purple, through magenta-crimson, crimson-scarlet, scarlet, orange, yellow, to cream-white, that is not represented in greater or less abundance, the lighter shades of yellow being the rarest. In the lower limits of its range the leaves are longer, narrower, and darker in colour, and the flowers are less numerous, somewhat smaller, and of uniform colour, merging into that of the form known in cultivation as $M$. Lindeni. It is only at and near the upper limits of its range that the pale yellow and the white varieties occur.

Near Bogotá also, this variable plant has been found, growing in patches several acres in extent, in a elimate of frequent ruin and dense fogs, at an elevation of 8,000 to 12,000 feet. From this locality pure white fiowers have been sent. I am informed by Consul Lehmann, that the local native name for $M$. coccinea is "La Banderita," or "the little flag." One of the dark crimson varieties has also received a name in the native vernacular, signifying "bull's blood," a nane now in use in horticultural parlance to distinguish one of the handsomest forms of the plant. Horticultural names have been conferred upon so many sub-varieties that it would be impossible to enumerate them all. Among the most striking forms may be mentioned atrosanguinea, with deep crimsonpurple flowers; corrulescens, magenta-crimson tinged with mauve; decorr, dazzling unagenta; miniata, vermilion-red with crimson veius; and lata, rosy-purple. So fur as I can ascertain, the pale yellow and the white varieties bave never been in cultivation.

The accompanying Plate may be taken to represent, as nearly ns can now be determined, the original form of $\boldsymbol{M}$. coccince collected by Linden.

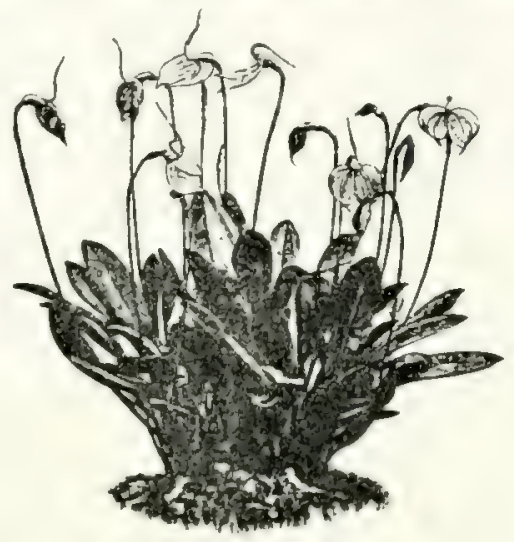






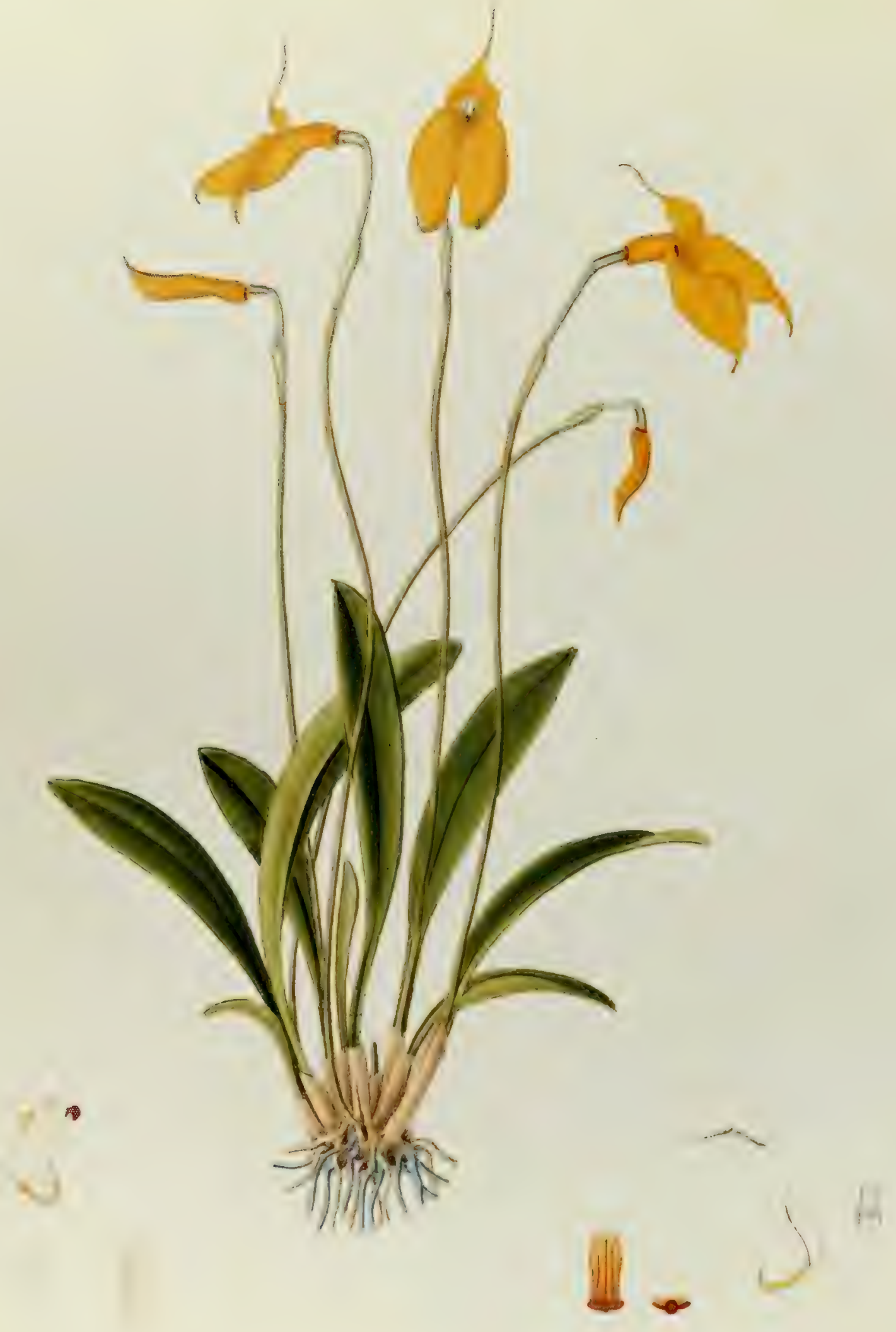




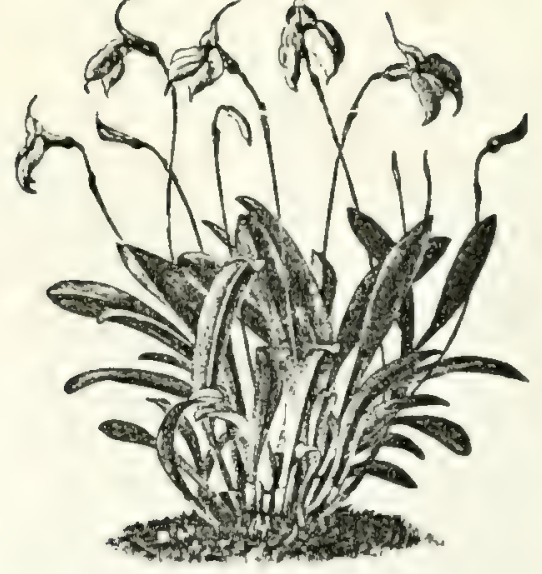

\section{MASDEVALLIA DAVISII Rehb. f.}

Masmevallia Davisir Rchb. f. Gard. Chron. 1874, pt. II., p. 710 ; 1876, pt. I. p. 366 ; 1881, pt. II., p. 236 : Bot. \ag. t. 6190 (1875); Gartenflora (Regel) XXV. (1876), p. 57 ; XXVII. (1878), p. 207 and 208 ; Xen. Orch. III. (1878), p. 3, pl. 203 ; Orch. Album (Warn. et Will.) II. (1883), pl. 76 ; Veitch Manual Orch. pt. V. (1889), p. 38.

Leaf $f$ or $i$ inches long, and about $\frac{1}{2}$ or 3 inch wide, ohlong-lanceolate, apex sharply tridenticulate, narrowing below into a slender grooved petiole, sheathed at the base, bright green.

Peduncle, with pedicel, 9 or 10 inches long, terete, slender, ascending from a joint near the base of the petiole, with two or three sheathing bracts, pale green, with small crimson streaks; flowering bract 1 inch long, oblong-ovate, apiculate, carinate, sheathing below, pale green.

Ovary about $\frac{3}{8}$ inch long, curved, with six rounded angles, bright green.

Sepals: dorsal sepal united to the lateral sepals for about a inch, forming a narrow tube, ovatetriangular for about s. inch, 3-nerved, terminating in a slender tail nearly 1 inch long; lateral sepals cohering for $1 \frac{1}{2}$ or 13 incb, oblong-ovate, 3 -nerred, terminating in slender tails nearly $\frac{1}{4}$ inch long ; all brilliant yellow.

Petals $\frac{3}{x}$ inch long. oblong, apiculate, anterior margin ktrongly keeled and angled, very pale yellow, the inner surface riscid beneath the keel.

Lip about 1 inch long, oblong-pandurate, with two obscure longitudinal keels, groored and fleshy at the base, united to the curved foot of the column by a rery flexible hinge, yellow, shaded and spotted with red, apex crimson, much reflexed, with a central velvety crimson cushion.

Colmm $\frac{1}{4}$ inch long, white, yellow at the foot, narrowly winged with crimson, apex minutely crenate, pale yellow.

DIscovERED in 1873 in the Eastern Cordillera of Peru, not far from Cuzco, by

Davis, a collector for Mr. Veitch, whose account of its habitat given in his "Manual of Orchidaceous Plants," I quote as follows: "It occurs on the slopes of the mountains at an immense elevation, probably not less than 10,500-12,000 feet, growing in loam and moss, and also in decaying vegetable matter collected in the erevices of the rocks. Its geographical range appears to be very restricted, extending but a few miles along the flanks of the mountains within the vertical limits stated above, but where, however, plants were seen in all stages of growth, from the smallest seedlings to masses of considerable size."

Explanation of Plate, drawn from a plant at Newbattle Abbey:

Fig. 1, petal, lip, and column, in natural position;-1a, section of ovary ; -2, petal, inner side :3 , lip ; - 3a, apex of lip; -4 , columa;-4a, apex of column; all enlarged; -5 , apex and section of leaf, naturul size. 




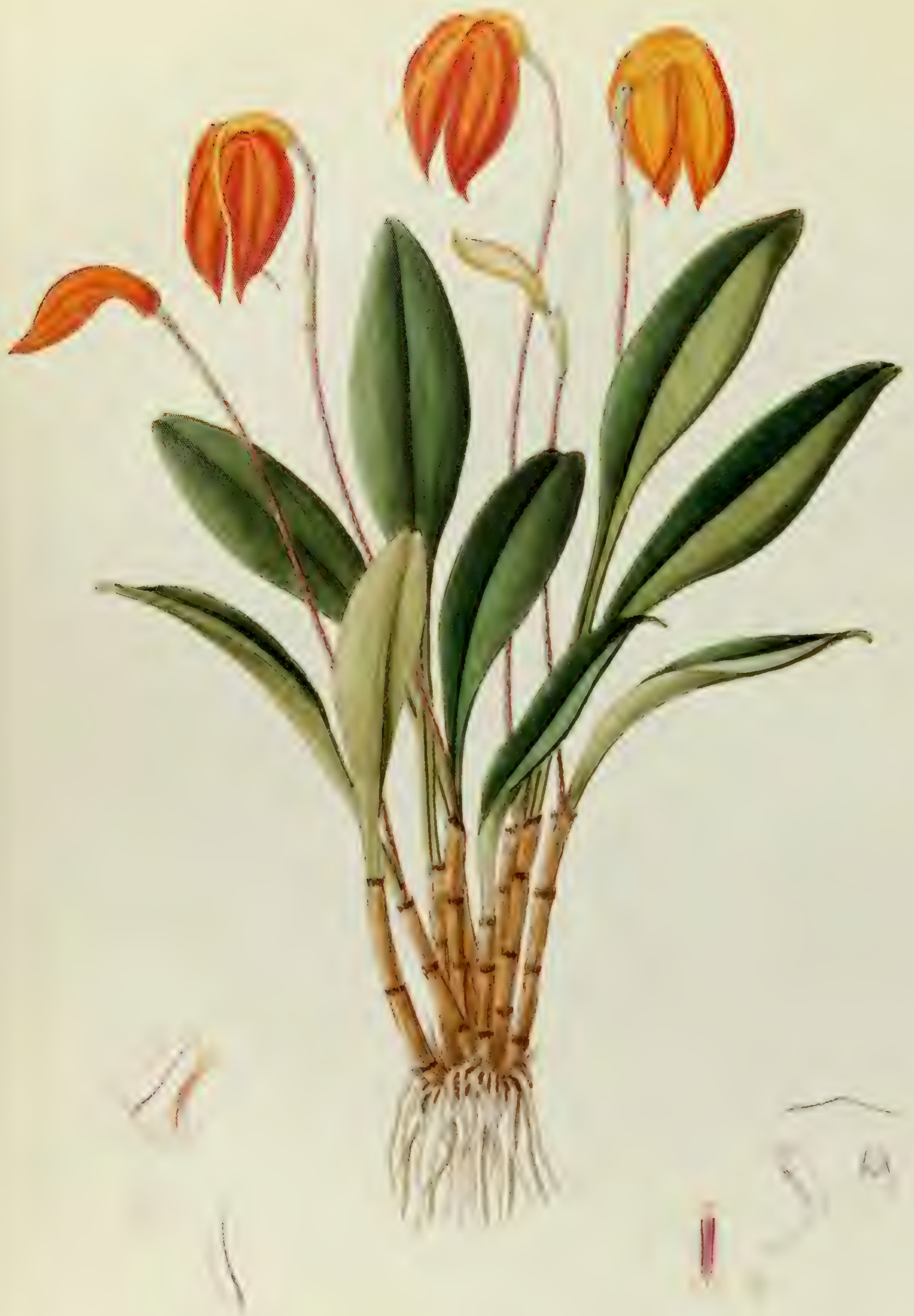




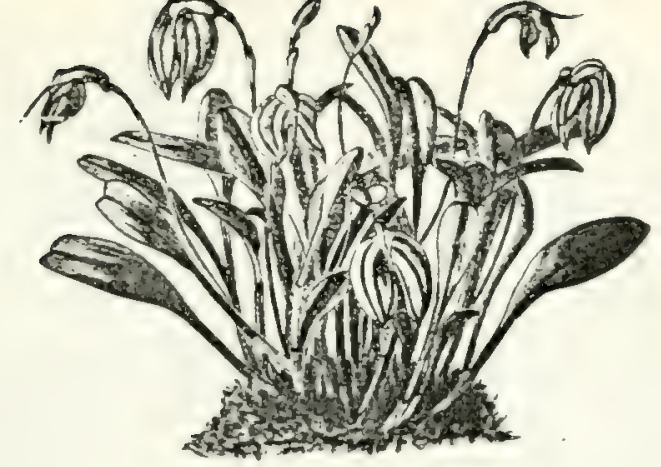

\section{MASDEVALLIA MILITARIS Rehb. f.}

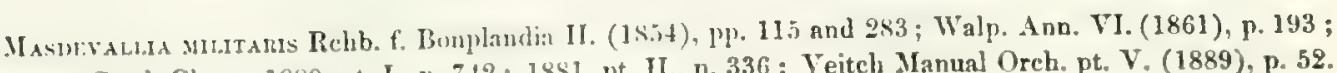
Gard. Chron. 1880, pt. I., p. 742 ; 1881, pt. II., p. 336 ; Veitch MIanual Orch. pt. V. (1889), p. 52.

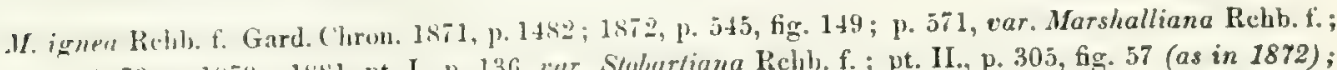

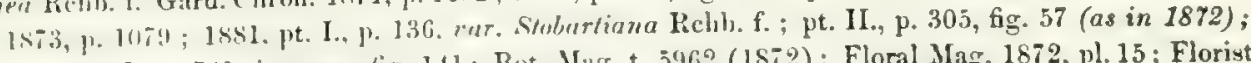

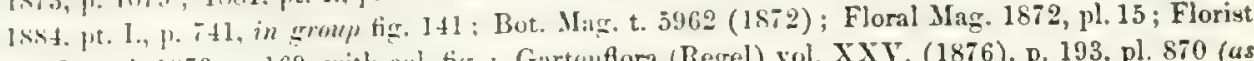
and l'ounl. 1s73, p. 169, with col. tig.; Gartenflora (Regel) vol. XXY. (1876), p. 193, pl. 870 (as H. coeriwer Lind.); Garden 1878, pt. I., p. 102, pl. CXIII.; 1885, pt. II., p. 289, with fig.; Illustr. Hort. vol. XXVI. (1879), p. 8, t. 333 ; p. 136, t. 357, var. Boddaerti hort. Lind.; Orchid Album vol. 11. (1583), pl. 62; vol. VI. (1887), pl. 273, rar. Mnssangeana Will.; Orchidophile (Godefroy) vol. I. (1881-3), p. 196, with fig.; p. 834; vol. V. (1885), p. 367, with fig.; Lindenia rol. V. (1s89), pl. CCXIX., p. 57 ; Veitch Manual Orch. pt. V. (1889), p. 46.

Leaff (with pretiole) \& or 9 inches long, oblong-lanceolate, coriaceous, slightly carinate, apex tridenticulate. dark green, narrowing helow into a groored petiole, sheatbed at the base.

Peduncle 12 to 15 inclies long, with two or three shenthing bracts, terete, ascending from within the - heatl at the base of the petiole, bright green streaked with crimson; flowering bract ahout 1 inch long, slieathing belor, orate-apiculate above, rellowish-green.

(Wary about ${ }_{n}^{3}$ inch long, with six rounded angles, green spotted with crimson.

Sepals: dorsal sepal united to the lateral sepals for nearly 1 inch, forming a narrow curved tube, free fortion triangular for ${ }_{n}^{3}$ inch, 3 -nerved. tapering into a slender deflexed tail $1 \frac{1}{4}$ or $1 \frac{1}{2}$ inch long ; lateral sepals colering for nearly 1 inch, elliptic-nval, 3-nerved, margin reflexed, terminating in short blunt crimun-scarlet tails : varjous shades of orange and scarlet, veined and edged with cinnahar-red.

I'etals nearly f inch hong, linear-oblong, curved, apiculate, with a strong keel near the anterior margin proloned helow into a curved angle, beneath which is a mans of viscid matter, tasteless and colourlesw; white or ivory, with a crimson central line.

Lip about $\frac{1}{4}$ inch long, fleshy and grooved at the base and united to the curved foot of the column by a Hexible finge. lincar-oblong, white and yellew, grrouved in the centre, with two short longitudinal crimson keek. marsini crenate ind more or less reflexed, apex recurved, cordate, apiculate, yellow.

Colunu + or 3 inch long, white, narrowly winged with erimson, apex more or less denticulate.

1 VERY variable species, of which the earliest known form was discovered by

Warcewicz in . January 1\%49, near Ocaña in the mountains of Santander, Colombia, at an elevation of 9,000 to 10,000 feet, and was named Masdevallia milituris by Profesior Reichenbach. Out of a large consignment of plants sent to Europe by

Explanation of Plate, drawn from a plant at Newbattle Abbey:

Fir. 1, petal, lip, and column, in natural position; - 1a, section of uvary ; - 2, petal, inner side ;-

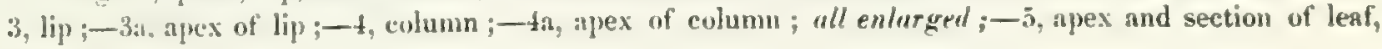
naturnl size. 

Warsewicz only a smali number survived the voyge, and specimens of these are still cultivated in a few collections under the name of $M$. militreris. No furrer importan of this plant was made until 1870, when Mr. Day, of Tottenham, introduced from the same locality a variety to which Professor Reichenbach gave the name of 11 . ignert, the two plants being for a long time considered distinct species. In 1871, when Profesisor Reichenbach published his first description of the brilliantly coloured $M$. igmen, he was probably not aware of the extreme variability of the species, having previously seen only the paler form collected by Warsewicz twenty gears earlier; his deseriptions are equally applicable to many of the rarieties now well known.

The fullest account of the habitat of $M$. milituris is given by Roc\%, who, in 1 sio, ako found the plant in the mountains of Ocaña. It was growing in countless thousmols on a slope, at an elevation of 11,000 to 12,000 feet, among low flowering shrubs, such an

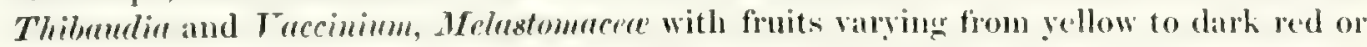
black, Agerntum in masses of blue and white, terrestrial species of Oncidium, etc., which, mingling with its yellow, orange, and fiery-scarlet ffowers, formed a brillint display of colour. Roezl relates that the brighter kinds of Mrestrenllien are greatly admired by the native Indians, who plant them in open spaces aceses in extent, and make use of them on festal occasions for decorating their chipels and huts. Among this abundance of specimens Roezl aud a companion remained for several days, collecting the finest plants in immense numbers to send to Europe. His valuable importation was, however, doomed to destruction, for it arrived at the port of St. Nazaire on the Loire during the Franco-German war, and was detained there so long that every plant perished.

The atmosphere at this great elevation in the mountains of Ocaña, although fiesh and breez, is always damp, with thick fogs every morning, and two raing seasoms during the year. Wet moss covers the ground and rises in little mounds over the roots of the plants, preserving constant moisture. The differences of situation aud altitude in which II. militaris grows cause infinite variation in the size and colour of its flowers, as well as in the habit of the plants, and even in their time of flowering. Plants growing at the lower level, in deeper soil or moler the shade of spreadiner shrubs, develop longer, more stender leaves and stems and less brilliant flowers, while those growing at a greatcr elevation, in rocky and exposed places, have short stiff leaves and more brightly coloured flowers. These characteristics are often retained by individual plants affer a long period of cultivation. Hence the wide range of variation seen in every collection. and the popularity of this species among horticulturists, under whatever namc.

A few of the most distinct varieties are: Mussmgenm, with large flowers, yellow and cinnabar-red; aurentircen, light orange-red; Borlderti, crimson-scatlet mathed with pale yellow; citrina, light orange-yellow; stebantimn, orange-yellow, tinged and edged with mauve-purple. Plants cultivated under the nane of $M$, ignere are of a much brighter scarlet than those called $M$. militoris; of the latter I have seen flowem sid to have come from one of Warscewicz's original plants. The flowerm here represented are nearer those named by Professor Reichenbach $\mathbf{H}$. igmed than those named by him .W. militoris.

Several hybrids have been rased between $M$. milituris (. 1 . igmon) and other specien:

M. Fraseri Rehb. f. Gard. Chroll. 1882, pt. I., p. 1433 tube orange-red, sepals magenta-crimson tinged with orange: raised in the collection of IIr. Fraser, of Demcleugh, Aberdeen, between.M. milituria (A. ignea) and M. coccimm ( M. Limdrmi).

M. Hinchiana Rehb. f., see M. torarensis.

11. Ellisiana Rolfe, Gard. Chron. 18xo, pt. I1., p. 15t; tube bright yellow shaded with rose, sepals richly tinted with orange, rose, and crimson; rased in the collection of Messrs. Veitch at Chelsen, between $\mathbf{H}$. curcinen rar. Hurymun and M. milituris.

M. Mundyane, Gard. Chron. 1891, pe. 1., p. G82; and M. Menthii, Gard. Chron. 1891, both raised by Mr. F. Sunder, of st. Albans, between M. milituris arm. anmontinces and af Voitrhirmon 




$$
\text { v }
$$




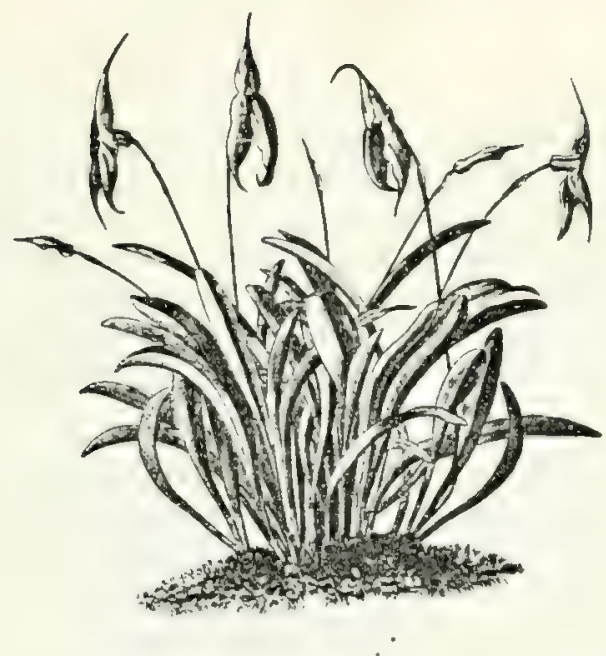

MASDEVALLLA VEITCHIANA Rehb. f.

Maknfyalia Veitchusa Rehb. f. Gard. Chron. 1868, p. 814, and p. $1338 ; 1871$, p. 1421, fig. 310A; 1879 , pt. II., p. 305, fig. 49x, w ; 1881, pt. II., p. 409, fig. A ; 1883, pt. I., p. 662 (rar. biflon Rchl,.f.) ; Bot. Mag.t. 5739 (1868); Illustr. Hort. vol. XV. (1868), p. 107; Flore des Serres t. 1803 (1865) ; Flonl Mag. rol. IX. (1870), t. 481; Belg. Hort. 1873, p. 361, Florist and Pomol. 1873, p. 169, fig. 1 of coloured Plate ; Warner, Select Orch. ser. 2 (1865-1875), t. 33 ; De Puydt, Les ()rcl. (1880), p. 289, t. 25 ; Lindenia, rol. II. (1886), p. 97, t. 95.

Leaf 9 or 10 inches long, livear-oblong, obtusely tridenticulate, carinate, dark green, narrowing below into a slender grooved petiole, pale green, sheathed at the base.

Peduncle 12 to 18 inches long, terete, slender, with two or three sheathing bracts, green, with small crimson streaks; flowering bract about 1 inch long, 5 or 7 -nerved, carinate, apiculate, sheathing, pale green.

Ovary $\ddagger$ to $\frac{1}{2}$ inch long, with six rounded angles, dull green shaded with crimson.

Seprals: dorsal sepal united to the lateral sepals for about $1 \frac{1}{4}$ inch, forming a narrow curved tube, free portion triangular-ovate for 1 inch, 3-nerved, tapering into a slender tail 1 or 2 inches long; lateral sepals colering for abut $1 !$ inch, free portions oblong-triangular, כँ-nerved, margins reflexed, tapering into slender tails $\frac{j}{q}$ or 3 inch long, inner surface of all brilliant orange-scarlet, more or less closely set with Nhort, translucent, purple hairs; outer surface pale yellow, nerved and shaded with scarlet.

Jetals rarying siglutly in different specimens, nearly $\frac{1}{2}$ inch long, linear-oblong, apiculate or tridcuticulate, anterior marcin narrowly keeled, terminating in an angle with a mass of viscid, tasteless, colourless matter beneatli, white, sometimes tinged with yellow at the apex.

Lip varving in different specimens, about $\frac{1}{2}$ inch long, united to the curved foot of the column by a Hexible hinere. H(chy at the hase, linear-oblong, margin variably reflexed, white and rose-purple, with two longitudinal, dark purple kerols, alpex sharply reflexed, very dark purple, with a relvety cushion of minute papillie.

Column 1 to 3 inch long, apex denticulate, white, narrowly edged with crimson.

$\mathrm{M}$

ASDETALLIA VEITCHIANA was discovered near Cuzco, in 1867, by Pearce, at an elevation of 11,000 to 13,000 feet, and was named and described by Professor Reichenlach in 1868. With Mr. H. Veitch's permission I quote from his "Manual of Orchidaceous Plants," Part V. p. 69, the following account by his collector Davis of the habitat of this species:

"Masdleallia Feitchioma occurs above the timber line, at the altitude above stated; the plants are found in the crevices and hollows of the rocks with but little soil about their roots, but sometimes where a small quantity of decaying vegetable matter has accumulated: in this case the plants are more robust, and when partially shaded by 

the stunted shrubs found here and there, or by projecting rocks, produce larger flowem; in the former case the plants are more tufted and more floriferous, but the flowers are smaller. At this great altitude, notwithstanding the tenuity of the atmosphere, the heat from the direct rays of an almost vertical sun is very great on clear days, but the nights are damp and chilly; the range of temperature is therefore very considerable. Vapour is constantly rising from the streams and valleys below, keeping the atmosphere always highly charged with moisture; besides this, rain is frequent, even in what is called the dry season."

Although $M$. Feitchiann rarely produces more than one flower upon the same stem, a plant at Newbattle, from which the accompanying plate was drawn, for several successive years developed stems bearing two flowers, the upper flower expanding some days after the lower, and being always considerably smaller. There were besides, singleflowered stems upon the same plant. Professor Reichenbach, to whom a two-flowered stem from this plant was forwarded noticed it in the Gardeners Chronicle, 1853, pt. I., p. 662, as var. biflora. Tariation in thize and colour of the flower appears to be due ouly to more or less successful methods $\delta$ f cultivation.

In the fint published figure of M. Teitchere plate 5739 of the Botanical Matrizine, drawn by Mr. W. H. Fitch, the plant is represented with a small pseudo-bulb, and several botanical publications, copying or slightly altering their plates from this figure, perpetuated the error: No species of the genus Mardecrllin has pseudo-bullys. The grooved leaf-stalk springs from a rigid rounded stem, often more slender than the leafstalk itself, and concealed by a sheathing bract-like membrane surrounding the base.

Several hỵbrids have been artificially raised between $\boldsymbol{M}$. Feitchirmo and other species of Masderallia, riz:

M. Chelsoni Rchb. f. Gard. Chron. 1880, pt. I., p. 55ั4; an artificial hybrid between M. amabilis and $\boldsymbol{M}$. Feitchiona; colour, orange-red, more or less closely set with minute crimson bairs.

M. splendens Rolfe, Gard. Chron. 1889, pt. I., p. 619; an artificial hybrid between M. Veitchiana and M. amabilis, the reversed cross of the above; colour, brilliant orange-crimson, with amethyst hairs.

M. Gairiana Rchb. f. Gard. Chron. 1884, pt. II., p. 38; an artificial hybrid between M. Veitchiana and $\boldsymbol{M}$. Davisii ; colour, orange-yellow, with crimson hairs.

M. splendida Rehb. f. Gard. Chron. 1878, pt. I., p. 493; colour, orange-scarlet, with purple hairs.

M. Parlatoreana Rchb. f. Gard. Chron. 1879, pt. I., p. 172; colour, brilliant orangescarlet, with crimson-purple hairs.

The two last-mentioned hybrids are especially interesting as having been found growing wild in the habitat of M. Veitchiona. Professor Rejchenbach, on examining wild specimens of $M$. splendida, suggested that the plant might be a natural hybrid between $M$. I eitchiana and M. Burlacena, or between M. Teitchimu and M. amabilis. His opinion was afterwards confirmed, a plant exactly identical with the wild specimens of $\boldsymbol{M}$. splendida having been raised by Mr. Seden, in the establishment of Messrs. Veitch, by fertilising flowers of MI. Feitchiana with pollen from flowers of M. Burlecump. M. Parlatoreana has been proved to be the result of the reversed cross, and las larger and more brilliantly coloured flowers than $\boldsymbol{M}$. splendide.

Explanation of Plate, drawn from a plant at Newbattle Abbey :

Fig. 1, petals, lip, and column, in natural position;-1a, section of ovary ;-2 and 2a, petals from different specimens, inner side $;-3$ and $3 a$, lips from different specimens; -4 , column; $-4 a$, npex of column; all enlarged; -5, spex and section of small leaf, nalural size. 



\section{CORLACE $\circledast$ Rehb. f.}

$\mathrm{M}^{\circ}$

UST of the plants in this Section bave rigid, leathery (coriaceons) leaves, and thich succulent fiowers, borne erect upon strong stalks, or pushed out laterally from the base of the leaf-stem. The flowers of nearly all the species have two well-developed necturies at the base of the lip, containing, in three or four instances, a considerable fuantity of honcy. In this Section are included the most fragrant and the most malodorous of the Genus.

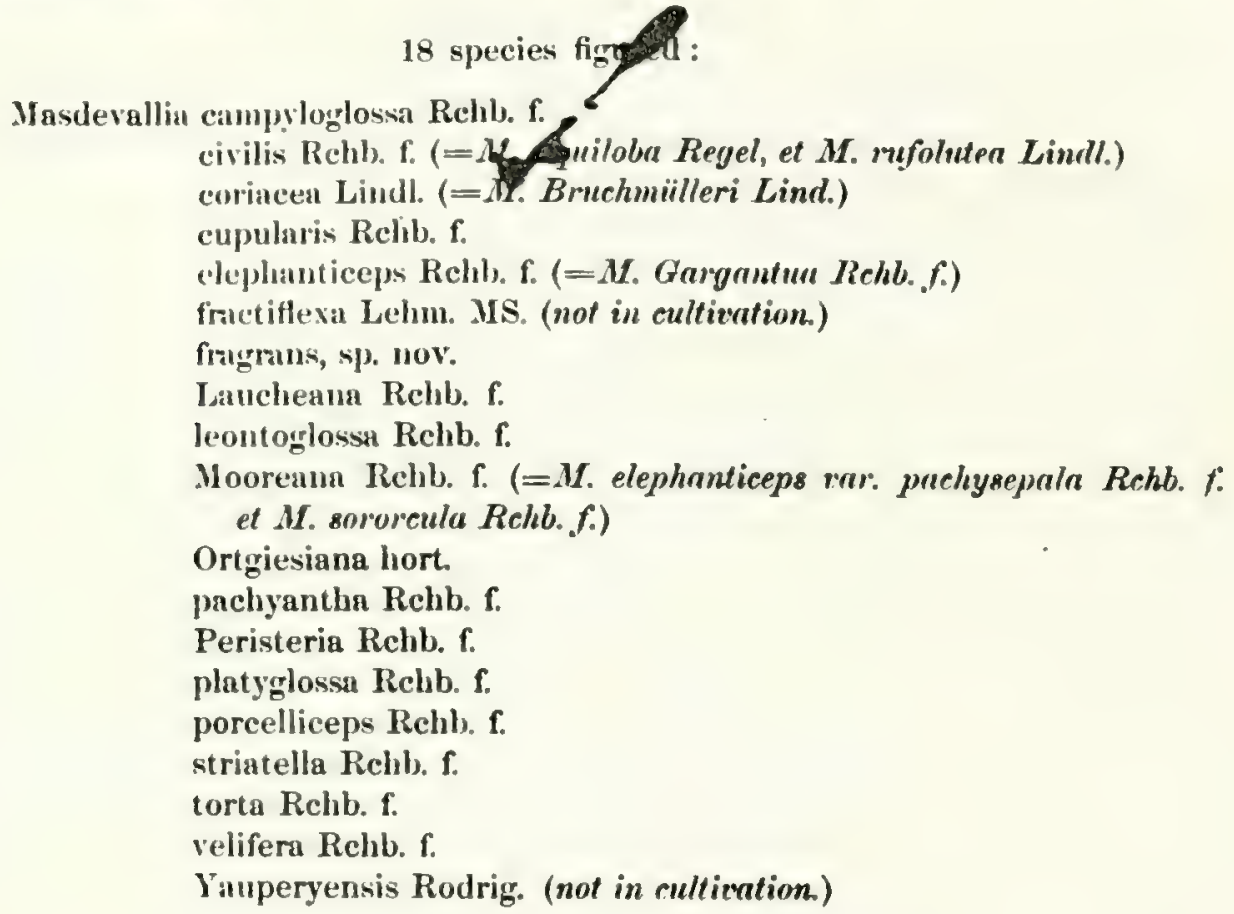

Not in cultication :

14. "yïnis Limll. Orch. Lind. (1846), p. \%. aligulatn Kehb.f. Otin. Bot. Hamb. (1878), p. 15. Bomplandii Rehb. Bomplandia IIJ. (15.55), p. 69. ('ugenupuxis Rchl.f. Otto et Dietr. Ally. Gurtenz. XXIII. (185io), 1). 248. chloricru lichb.f. Flum (Singer) $1886, p .560$. pllipes Kchb.f. Limnen XLI. (1877), j. 11. ensut" Kchb.f. Limnaen XXII. (1849), p. 818. fractitlexи Lehm. (see Plate). heterotepull" Rehb.f. Floru (Singer) 1886, p. 561. levis Limll. A un. Nat. Hist. (1845), p. 25\%.

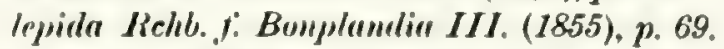
mucroglosen Rchb. f. Otia. Bot. Hamb. (18\%8), p. 15. jurdinu Rehb. f. Otin. Bot. Hamb. (1878), p. 15. Yauaperyensis Ronlriy. (ace I'/ate.) 



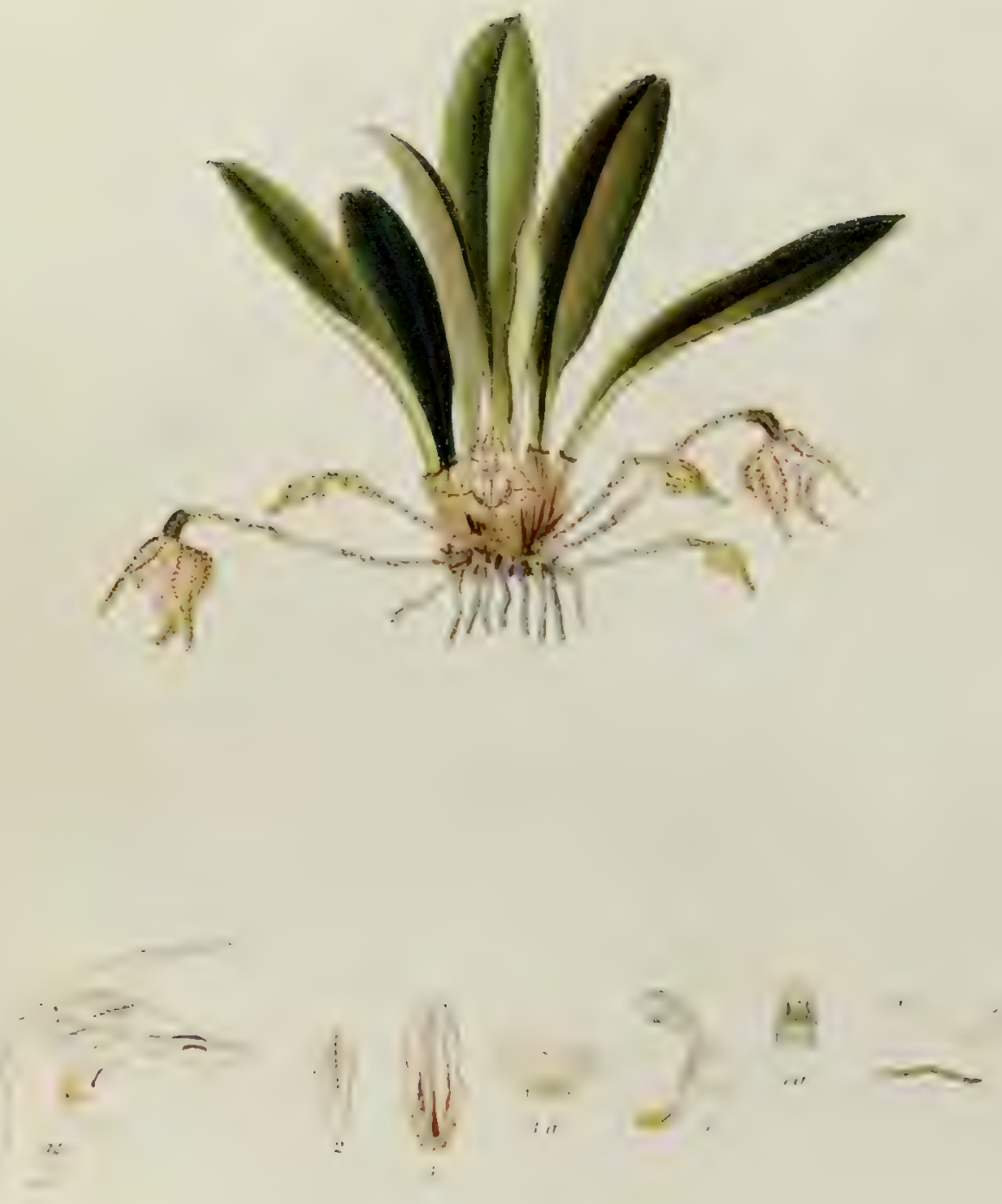


\section{MASDEVALLIA CAMPYLOGLOSSA Rchb. f.}

Masmevaldis camprongzossa Rchb. fo Gard. Curon. 1878, pt. II., p. 388 : Orchidophile (Godefroy") Ix81, p. 84; Veitch Manual Oreh.pt. V. (18*y), p. 27.

Leaf about 4 inche: long, ohlong-lanceolate, very thick and leathery, stiff and erwet, ubtusely triden. ticulate, dark green. sommetimes tinged with dull red, narrowing below into a ktout grooved petiole, shesathed at the hase.

Peduncle, with the pudicel, abme 2 inches lung, terete, slender, growing laterally from the base of flue petiole. with two or tluree sheathing hracts, pale green spotted with crimson; flowering bract ahout f inch long. apiculate. alueathing ledow, with a rudimentary bud within at the base, pale green when roung. with crimson spots, fiding to pale hrownisls-yellow.

(Wary a little more than $\downarrow$ inch long, mucl, curved, with six rounded angles, very dark green, with minute crimson spots.

Sicpals: dursal repal united to the lateral sepals for $\frac{1}{1}$ inch, forming a wide tuhe or cup, free portion uvate.triangular for nearly 3 inch. 3-nerved, tapering into a fleshy tail nearly $\frac{1}{2}$ inch long; lateral sepals cohering for alsut 3 inch. free portion crate triangular for nearly a inch, 3-nerved, uerminating in a fleshy tail $\frac{1}{4}$ inch loug ; all pale gruenish yellow, with numerous crimson spots, chiefly upon the nerres.

l'etals nearly 3 inch long, linear at the base, upper part orate, acuminste. with st sharp angle on the anterior martin, very pale green, with a central line of dull crimson spots.

Lip sibout $\frac{1}{2}$ inch long. united by a strong hinge to the foot of the column, whlong, curved, crenate at the margin. surface rough. especially towards the apex. whitish-green. with three longitudinal criman lines, apex green.

Colum shorter than the petals, stout. marrowly winged, apex slightly crennte, green. the foot yeflow.

THE habitat of this species is unhnown, and the only information to be obtained ahout it is, that it was purchised at a sale of Orchids at Stevens' Rooms, in 1878, by 11 cass. Veifeh, who distributed specimens anong the few collections which possexs the plant.

Foxplamation of l'ate, drawn from a plant at Newlattle Dbbey:

Fig. 1. peral. lip., and colmun. in uatural position;-1k, section of ovary ;-2, petal, inger side :-

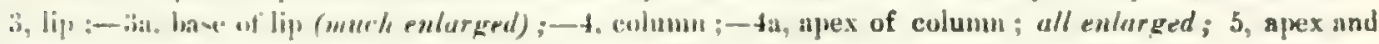
section of lati, natural sise. 



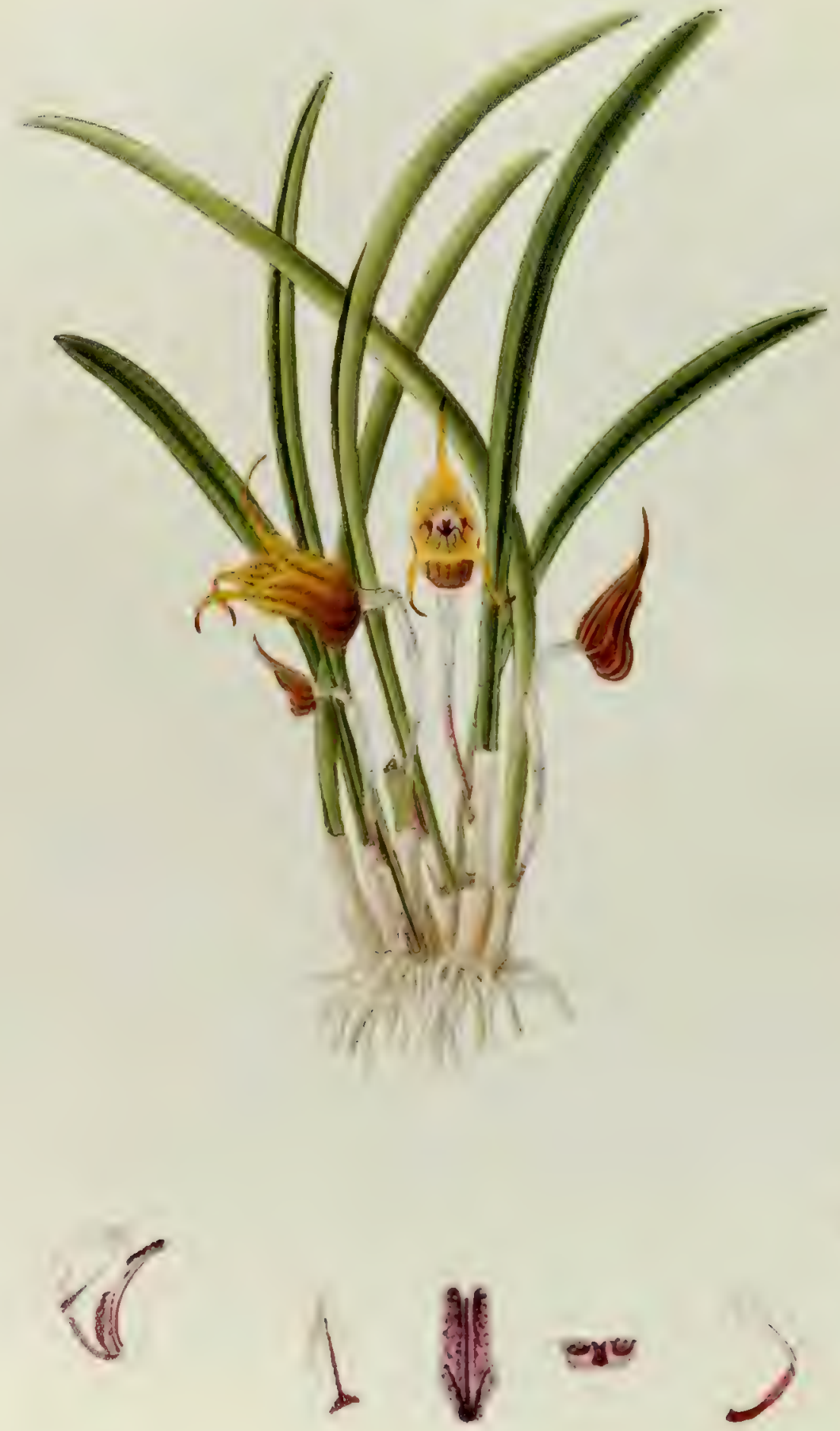


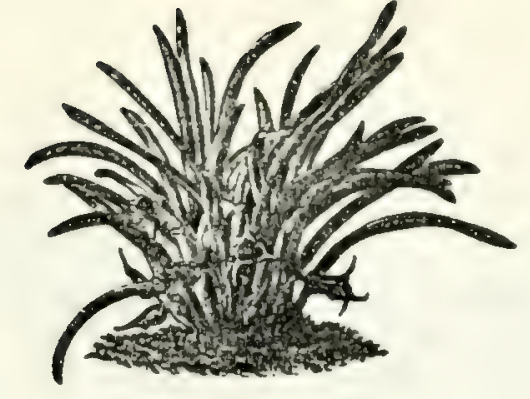

\section{MASDEVALLIA CIVILIS Rchb. f.}

Masingalua crouls Relih. f. Honplandia II. (185t), p. 115 ; Walp. Ann. VI. (1861), p. 191 ; Bot. Mag. t. 5476 (1864); I3elg. Hort. 1873, p. 356 ; Gard. Chron. 1881, pt. IL, p. 236; Veitch Mantul Orch., jt. V. (1889), p. 33.

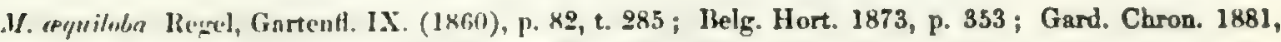
pt. II.. p. 236 ; Mrchidophile (Godefroy), 1881, p. 83.

U. rufoluled limbl. Wrswez. Cat. 1853; Gard. Chron. 1853, pp. 192 and 328.

Leaf $\&$ ur " inches long, 3 to $\frac{1}{2}$ inch wide, linenr, recurved, very thick and fleshy, apex obtusely triden. ticulate, dull Ere'en, narruwing below into a very thick, deeply-grooved, pale green petiole, with large membramus alicatlis at the base.

l'eduncle. including pedicel, sbout 3 inches Jon: with two or three sheathing bracts, erect, terete, attenuate tuwards the base, bright pink below, greevish above, with numerous small crimson spota; flowring hmet $\frac{1}{2}$ inch long, 3-neried, clonely shenthing below, nitu a rudimentary bud rithin at the base, pale enceen or jurplish.

Ovary alsut $\downarrow$ inch long, with six rounded anglex, whining, paie green spotted with crimson.

Seprals: domal nepal united to the lateral wepals for shout $\$$ inch, forming a wide tube ; lateral repals cohering for nbut I inch. gibbous lx.nenth; all kepals ovate-triangulnr for nearly \& inch, 3-nerred, feehy, sternish-yellow sputted with dark crimson-hrown, inner surface rough with minute silver-white hairs, unter aurfuce whining, crimsun near the banc, nerves dotted with minute brown spots; enc'l sepal termin. ating in s slenter fattenerl tail, omnge-vellow in front, dark brown or spotted at the back.

Petal alsut ! inch Jong, whglitly curved, linenr at the basc, very thick and fleshy, wangins angled and murl, thirkencel. White. very hining, with n broad rentml atreak of crimson, base rich crimson, spez ante. errenislt.

l.ip a little longer than the petnlw, oblong, Heshy, lase deeply grooved in the centre, with a bollow merary un each sile, anterior portion with one central and two lateral keels, all widening and terningting ill a roundenl warty line, dull frevish-white, with numerous dark crimson spots, npex rougb with obtuse pappillie. blackish crimson.

Culum 3 inch long, very thick. winged, palc green untride, brilliant crimson within, foot dark rich arimson.

$\mathrm{M}$

ASIOEY ILLIA CIVILIS was discovered by Wancewicz upon the eastern slopes of the Peruvian Anden, and was first described by Professor Reichenbach in 1854 I description and an uncoloured Plate are given by Regel in "Gartenflora " of 1860,

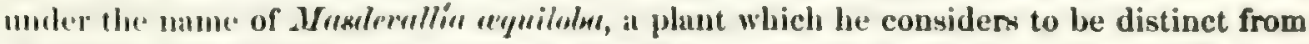
U. rivilix, and which was also collected by Wancewicz in the Andes of Peru. The very

Explamation of Plate, drawn from a plant at Sewhattle Abbey :

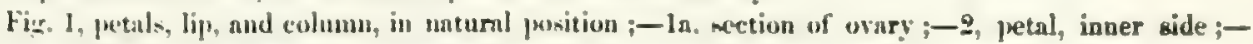

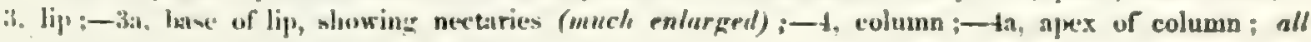

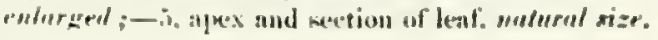



trifling differences meutioned by Regel, chiefly some small characteristies of the flowering bract, do not, however, justify specific distinction.

A dried specimen in the Lindley collection of Mnsdemallin in the Royal Herbarium, Kew, collected by Wancewicz at the sources of the Marnnon (or Amazon) in May, 18\%3, and named by him MI. myfoluter, is identical with $M$. cirilis of Professor Reichenbach, who, during one of his numerous visits to $\mathbf{K e w}$, wrote underneath this specimen the name $M$. cirilis. No botanical description was ever published under the name mfoluter, which first appeared in a catalogue of the sale of Wancewicz's plants in 1653.

The thick, rigid, and very narrow leaves are a marked characteristic of $U$. cirilis, the flowers of which species, outwardly dull and unattractive, show internally great beauty of structure and colouring. The suceulent sepals and petals of this and of many allied species are, in cultivation, often found to be gnawed by small insects. In their native wilds, where the insect necessary to the requirements of each species is probably to be found, it is possible that this dainty food may be the menns of attracting suituble insects to aid in the work of fertilization, Honey is rarely present in the small nectaries more or less dereloped in every species nearly allied to $\boldsymbol{M}$. cirilis, but the surfice of the sepals and petals, and sometimes of the column, is often intensely shining, or covered with viseid watter-perhaps equally attractive.

Hardly anything is known about the method of fertilization of any species of Masdlevellia, although in a wild state most of them appear to ripen seeds in abundance. In the Herbarium Boissier at Chambésy, near Geneva, nearly all the specincus of Mastevallia (more than 150 in number, most generously placed at our dispowal for the furtherance of the present work), show fine capsules in various stages of developenent. The large size attained by a ripe capsule in proportion to its size during the flowering stage is very remarkable.

Consul Lehmann gives the locality in which he has found this species:

Masderallia cirilis is found in the ricinity of Huancabamba, in the Department of Piura, North Peru, at an elevation of 2,100 to 2,500 metres $(6,805-8,125$ feet). It grows unong grasses and small shrubs in loany soil, and upon rocks where thin layen of veretable matter and soil have accumulated. The plants are a good deal exposed to the sun, and to the winds which sweep during several months of the year over the high planis of the Andes. Those exposed to the full influence of the sun are much smaller and have darker flowers than those growing partly sheltered and shaded under the shrubs.

The annual temperature of the above region is between $14^{\circ}$ and 16 centigrade (about $57^{\circ}$ to $61^{\circ}$ Fahrenheit).

F. C. Leumas: 





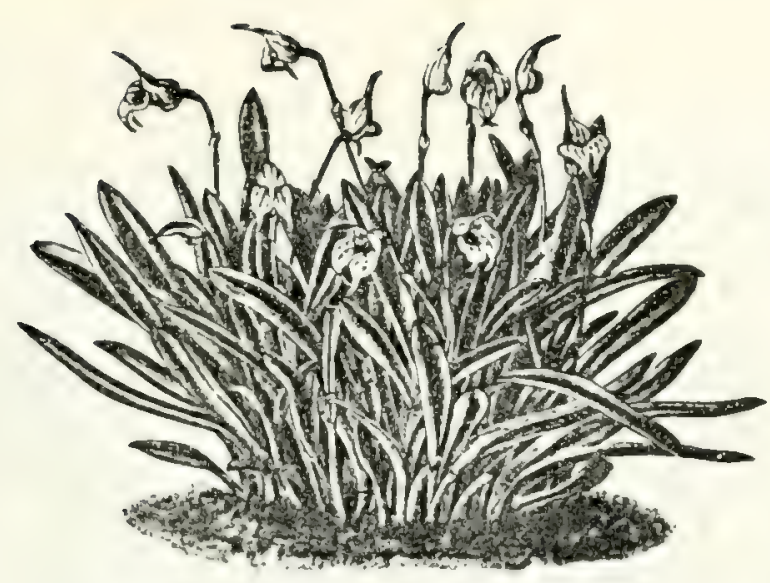

MASDEVALLIA CORIACEA Lindl.

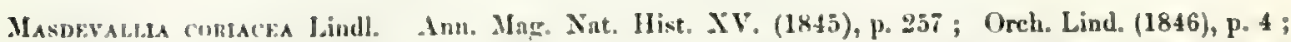
harsten Flom Coloml. (1869-1869) vol. 11., 1. 103, t, CLIII.; Gard. Chron. 1872, p. 1067 ; 1881; pt. 11. P. 236 ; Belg. Hort. 1sia, p. 356; Veitch Manual (trch. pt. V. (1889), p. 36.

M. Bruchumilleri Jituden Cat. n. 90 (1873) ; Bkelg. Llort. 18i3, p. 355 ; Gard. Chron. 1881, pt. II., p. 236.

beaf ti or 8 inclues long and about 5 inch wide, linear, slightly carinate, thick and fleshy, apex obturely tridenticnlate, dull green, narrowing into a thick, grooved petiole, shenthed at the brose.

P'eduncle, incluling the pedicel, about 7 or 8 inclues long, with two bracts, tesete, 1 -flowered or rarely 2-flowered, ancending from a joint at the hase of the petiole, pale green spotted with crimson; flowering bract ahout 1 inch long. orate-ncuminate above, slienthing below, s.nerved, pale green spotted with purple.

Ovary ubout 3 inch long, with three brond und three uarrow rounded angles, shining, bright green, minutely dotted with crimson.

Sepals : dormal repal united to the latenal sepals for $\frac{1}{2}$ inch, forming a wide tuhe, free portiou ovatetriangular for ! inch, 3.nerved, greenish-white, spotted along the nerves with crimson; . lateral sepals coldering fir about an inch, free portions ovate-triangular for nearly inch, 3-nerved, greenish-white, covered on the inner surfare with minute white hairs, nerves pale green spotted with crimson, the spots vers ammerous at the base of the tube : all the sepals terminating in thick fleshy tails $\frac{1}{2}$ to 1 inch long, erreenish or dull pale yellow, spotted nt the back with crimson, green at the apex.

Perals ! inchl long, whlanceolate, thich and fieshy, with a proninent angle near the centre of the anterior margin, heneath whin the inner surface is covered with thick viscid matter, tasteless and colour. lens: shining white, central nerve crimson, npex greenish.

Lip abut! ! inch lon:, ol, long, with two longitudimal, angled keels, greenish-white, with three crimson line terminating letare the apex; base fleshy, united to the cursed foot of the column by a flexible biage, deeply frowned. with a wide hollow nectary on each side, purple with minute dots; apex triangular, treenish, crenate and covered with minute papillse.

Colmun almut ! inch bong, pale green, narrowly wiuged with crimson, apex minutely denticulate, foot white or pink, youtted with erimson.

$\mathrm{M}$

ASIME ILLIA CORIACEA was diseovered by Hartweg on the hills of Montserrate near Bonoth, and his dried specimens were deserilsed in 1815 by Dr. Lindley. Shortly afterwards it was found hy Linden at an elevation of 7,200 feet, growing upon trees in the forests of Fusagrisuga in the Province of Bogoth, flowering in December, the temperature at this altitude being about $59^{\circ}$ Falirenheit.

F.xplatuation of l'hate, druwn from a plant nt Sewhattle . lbley:

Fit. 1. pretal, lip, and column, in uatural position; $-1 \mathrm{an}$, section of ovary ; -2 , petsl, inner side ; -

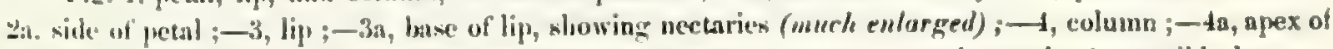
column : all enlursed; -5. apex and section of leaf, natursl size; -6 , seed-eapsules from wild plant. 

Dr. Kanten, in his "Flon Colombige," gives a drawhy of the plant from fresli specimens found by him in the mountains of Bogrota, $8-\$, 000$ feet above the level of the sea, where it grows in dense masses upon moss-covered rocks, and on the harh of tren, over which it spreads its fleshy rounded roots.

The species seems to be a variable one, for, in the Plate above mentioncel, flue flower are represented as bright yellow, and Dr. Lindley also, in hix description both of Hartweg's and Linden's plants, states that the colour of the flowers is yellow. The accompanying Plate represents the ordinary form of $\boldsymbol{M}$. comincen now in cultivation, and I have never seen a plant of this species with distinetly yellow flowers. A more hrighth

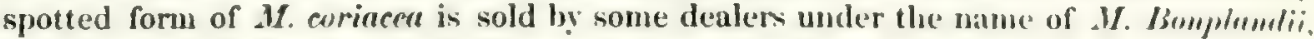
the spots within the tube of the flower and upon the lip being especially mumerom and brilliant.

I am informed by Consul Lehmann that the true M. Bomplondii of Reichenhach is a totally distinct species, more nearly allied to $M$. civilis than to .M. corrucen. Profinor Reichenbach in 1855 described it as a distinct species, and in 1822 decided to com-idher it only a variety of $\boldsymbol{M}$. coriacen.

The fint living plants of $M$. corincen imported into England were those sent in lis| to Messm. Hugh Low and Co., of Clapton, by their collector Bruchmiiller, in whon. honour they named the plaut $M$. Bmchmillpri, under the impression that it was an unknown species.

Fig. 6 of the accompanying Plate shows ripe seed-eapsules of $M$. corifcen, drawn from dried specimens in the Boissier Herbarium at Chambesy near Geneva, and found in $1 \times 2 * 3$ by Consul Lehmann on the Savaua de Bogota. To the generosity and courtesy of Mom. Eugène Autran, Curator of the Boissier Herbariun, 1 an indebted for the opportunity of making this interesting addition to my drawing.

Consul Lelımann's note on this species is as follows:

M. coriacea grows on sandstone rocks upon which thin layers of soil nud decaved lenves have accunulated, and is found along the westem border of the Sarana de Bogoti, at an elevation of 2,500 to 2.6in metres (about 8,125 to 8,612 feet). It is plentiful in the vicinity of Bojaci, Fncitativa, Trus Empunam anul Subachoque, and in all these localities it is exposed to severe changes of climate-sun, rain, and stronu

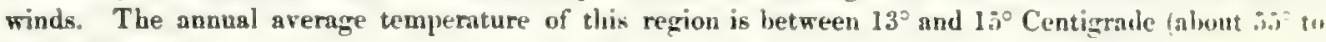
$59^{\circ}$ Fabrenheit). 


$5+1 \cdot \operatorname{sen}^{\circ}$ 


\section{MASIEVALLIA CUPULARIS Rchb. f.}

Mastivalda cureqaus Rehb.f. Beitr. ()reh. Centr. Amer. (1866), p. 93; Gand. Chron. 1879, pt. I., 1. 5oty; Godu, et Snlv. Jjologia Centr. Imer., Bot. Heinsley, vol. III. (1882-1886), p. 207 ; Orehidoplaile 1888, p. 162.

L,af about 2 inches hon, oval. coriaceous, carinate at the back, apex tridenticulate, narrowing below intu a sender growred prethile sheathed at the bare, bright green.

leduncle, with the jedicel, a little longer than the leaves, terete, erect, slender, attenuate below, with two whething bracts, pale wreen; Howering bract about $\frac{1}{6}$ inch long, membranous, acuminate, sheathing below, with a minute rudinontary bud within at the base, brownish-green.

() bury $f$ incli long, curved, with three large aud three small rounded angles, bright green.

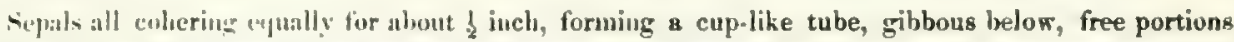
triangular-wate for 3 inch, 3-nerved, the principal nerves carinate without, semi-transparent, reddish. Pellow, cloms spotted with crimson, the nerves green; terminating in slender thattened greenish tails, inted witle red at the bave, rather more than $\frac{1}{2}$ inch long.

Petals $\downarrow$ inch lomg, oblong, apiculate, with a rounded angle on the anterior unargin and a kmall keel near the oppusite side, dull yellow spotted with red.

Lip nearly twice as long as the petnls, lobed and fiesby at the lase, and united to the curved foot of the colum by a texible hinge, oblong-cordate, ungius reflexed, yellowish, spotted and stained with red, with alark red longitudimal liuen, the spex studded with long crimson prpilla, much reflexed.

Columm ${ }_{x}^{3}$ inch long, murrowly winged, apex denticulate, foot mucl curved, green, tipped with white and elged with crimson.

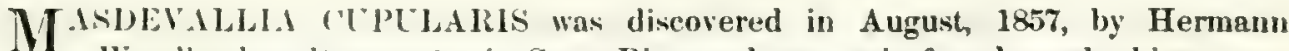

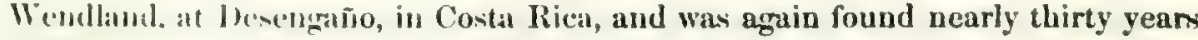
ifler, by Haibch, in the sume locality. It is still a more plant and exists in very few collection-, all the - peceimens in cultivation laving probably originated from an importation of Hübchis plants ly Mr. Sander, with whom it finst flowered in 1887.

Lixplanation of Plate, drawn frum a plant in the collection of Mr. Sydney Courtauld:

Fig. 1. petal. lif, aud column, in natural position;-1n, section of orary ; -2 , petal, inner side ; -

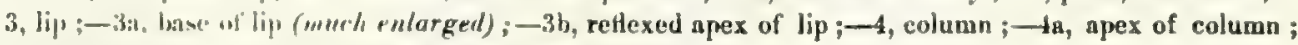

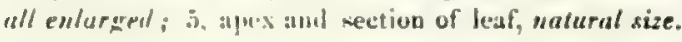






$$
s 0 \times \bar{j}^{\circ}
$$




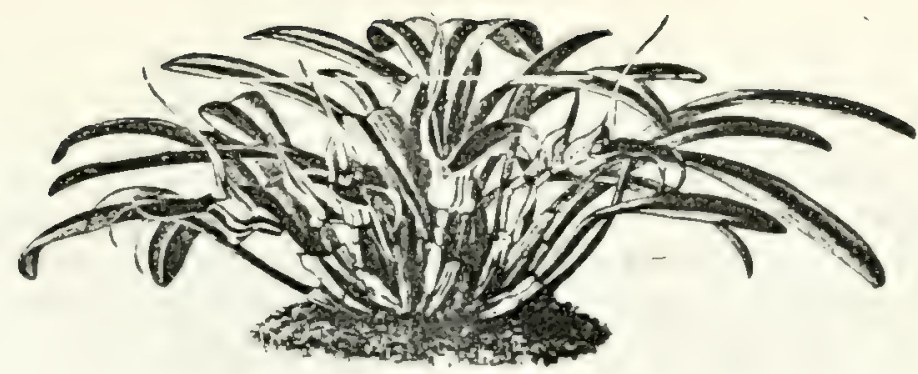

MASDEVALIAA ELEPHANTICEPS Rchb. f.

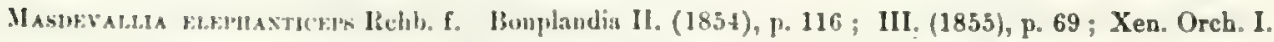

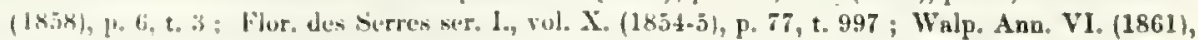
P. 192; Gard. ('hrou. Is\&1, pt. II. 1. 236; Veitch Manual Orch. pt. V. (1889), p. 40.

.H. Gurganlun IReh. 1. Garel. ('hron. 1876 , pt. II., J. 516 ; 1881, pt. 11., p. 303 ; 1886, pt. 1., p. 13;

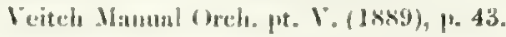

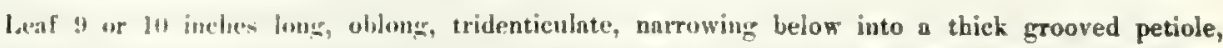
sheather at the balac. bright arreen, with a few crimson spots, the younger ones very bright, the older ones tinered with rich jurple.

l'alunele 1! inch long pedicel abuut the sam. length, terete, with wo sheathing bracts, ascending frum within the whenth at the lyase of the petiole, green, with crimson spots; flowering bract about 1 inch lune. osate, apiculate. Aheathine below, brownish-ereen, with a minute rudimentary bud within at the bare.

Wary nearly ' incli lone, with wix rounded angles, bright green, witb crintson spots.

Sipplals: dormil sipal united to the lateral sepals for about 3 inch, forming a wide tube, gibbous below, tree purtion orate-triangular for ubout $\$$ inch, 3-nerved, tapering into a tattened fleshy uil about 19 inch loner. brillant lemun-rellow, the mil brighter yellow, green at the back; lateral sepals cohering for 23 inclus. free portion oblown-ovite, ungled nt their junction, margins rettexed, 3-nerred, the nerres pruminent on the outer surfice, deprescel within, deep reddisl-crimson, rather shining, the surface covered with blunt excresecences, yellow at the margins, tube pale greenish-yellow, deeply stained with crimson within at the biste, very thich sud substantial.

l'etals about ${ }_{s}^{3}$ inch long, thich and fleshy, oblong-ovate, anterior margin with a thick augled excrescence, beneath which the whilice is covered with culourless viscid matter. white, shining, with a rich crimsun central streah and a fow spots.

Lif about 1 inch lomg, whlong, Heshy and grooved at the banc, and united to the foot of the column by at texible hinge, with a ahallow nectary vis each side, margins reflexed, greenish, broadly bordered with crimsm, rough with japillit, the apex dark crimson, with a rounded central line, and covered with coarse Inanchine purple-crimson hairs.

('olumn stbont ! inch lumg, very thick, broadly winged, green edged with crimson, spex minutely denticulate, martrin etuded witlo minte viscid drops.

'THE firt specinem of this magnificent plant were dried ones sent with a drawing to

l'rofienor licichendach ly its discoverer, Warscewiez, who found it in 1850, in the mountain of simbanker, leetween Ocana and Pamplona, growing in woods on damp turfy ground, in a temprerature of 6 to 10 Réaumur (about $46^{\circ}$ to $55^{\circ}$ Fahrenheit). It Wan aloo found hort! afterwards by. Wagener and Schlim, in woods near Ocaūa, at an

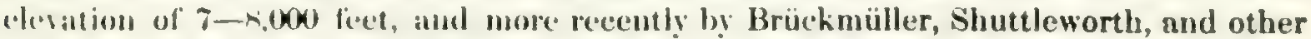
collectors. Warncewiez's drawing, published by Reichenbach in his "Xenia Orehidacea." represents a very large flower, larger, probably, than any yet produced in

Explatation of l'late, drawn from a plant at Niewhatile Abbey:

Fiz. 1. peral, lijp, and columu :-1a. stetion of ovary;-2, petal, inner side ; $-2 \mathrm{a}$, side of petal ;3. Jip: -3a, bave of lip. shwing necturies; -4 , cotumu; -4a, apex of column; all enlarged; -5 , apex and nection of leaf, molurnt size. 

cultivation. The fint plants which flowered in this country were inported by 11 e.m. Veitch in 1874, from Frontino in Antioquia, and when Professor Reichenhach received from Mr. Veiteh ruther suall fresh flowers from these plants, he gave them the specific name Gargantur, failing to identify them with the dried specimens to which, more than twenty year before, he had given the name eleghenficeps. His description of the colnur-

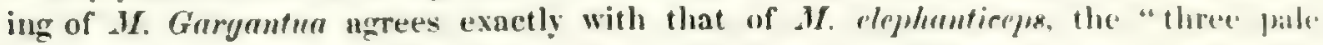
whitish stripes on each side" being the opaque prominent uerven, through which the ruddy erimson within the flower is not apparent. The phat is now erown in man! collections of Masdevallias under the two names, the flowem heing alwas identical.

In describing the fresh flowers Reichenhach notices their stromp disingreathe -medl - a characteristic which must of course have been alsent from the dried specimedr. This odour is pereeptible at some distance from the plant, and so exactly resemblen that of tainted meat that it speedily attracts flies. It is most powerful when the flowem fim open, and ceases gradually before they fade. I have mỵself olserved that flien latd ench deposited their egen upon the surface of the flower, but when the young wruls hatched. they failed to find sustenance in its tiscues, and perished. Althongh the odour mun lo inteuded to attract some insect suitable for fertilising the fower, I could and perevir. amy method by which flies or their larve could effect this purpone, or that they coubl hy aug possibility remove the rather strougly attached anthers. Some more vigroms insed -possibly a beetle-doubtless exists in the native habitat of this phat, specially adapted for the fertilisation of the flower, and attracted toward it be the peedular odour which it emits.

It was with an importation of .U. meghomticepu made hy Mr. Bull from Ocaña, that our new species $M$. forgrom was introduced. The plant manimed in hiv collectim until

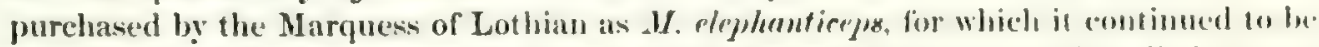
mistaken until the appearance of its pale yeliow fragrat flower proved its distinctuess.

Reichenbach's $\boldsymbol{M}$. elephanticeps mr. pucluysepuln is no doubt identical with $\boldsymbol{H}$. Moorenna, of which a Plate followi in due order.

Mr. Lebmann adds the following intomation:

Masdevallia elephantice ys has mther an extensive distribution over the nurthern pharts of (olumbia. but always seems to occur but sparingly. In the State of Santander it is chicfly uct with aroumd ()arian. and in Antioquia it is to be found in the wood between Guarne and Santo bominer. In butlo lexalities the elevation is from 1,800 to 2,100 mitres above bea-level ( 5,850 to 6,425 fect), and I think that it was frum the latter place that the plants named by Reichenbach $M$. Garganfus were foumd. It growo un trom mas the ground, and sometimes also upon the steep rocky sides of deep ravines. 



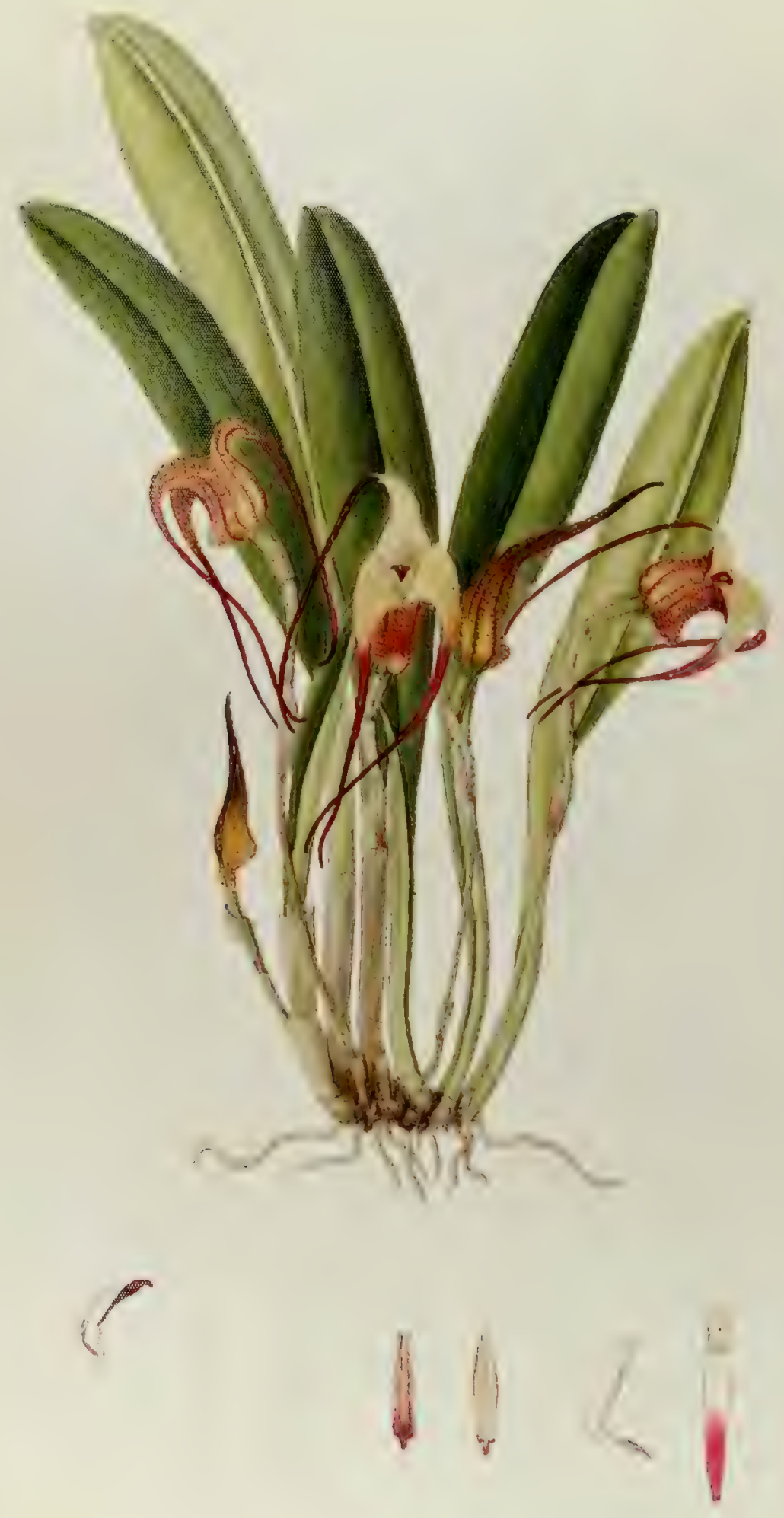


\title{
MASDEVALLIA FRACTIFLEXA
}

\author{
-p. nov. Lehm, et Krinz. MS.
}

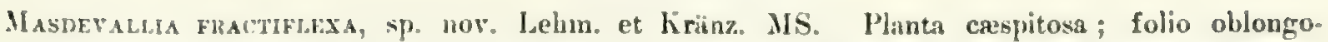
lancenlato, coriaceo, mareine revoluto, apice tridenticulato, viridi, in petiolum sulcatum robustum sensim angrustatn. has vitrinato: pedunculo uniftoro, tereti, erecto, curtiore quam folio, basi bracteis vaginantibus vestito, viridi, rubro-maculato; bractea sub hore membranacea, supra ovata, infra vaginanti, apiculata ; ovario costato, viridi, rubro-maculato; sepalis in tubum constrictum connatis, basi in mentum producto, carnosis, limbis ovatis, trincriis, in caudas triquetras sensim elongatis, abrupte reflexis, viridi-luteis, ('xteriore minutu transverse rubro-striato, caudis coccinejs; petalis linearibus angulatis, pallide luteis, apice virili acuto: labello lincuri. marcine revoluto, pallide luteo, coccineo maculato, apice trilobato, coccineo, papilluso : columnir netalis aefuilongra, apiculata, pallide lutea. rubro marginata, pede rubro.-Species nora sectionis Cariacea IRchb. t-Uah. Ecuador. Lehm. Herb, 10,020 .

Leat about 10 inches long, olloner-lanceolate, coriaceous, apex tridenticulate, green, narrowing below into a grooved petiole. sheatled at the base.

I'eduncic. including thr predicel. alout 4 inches long, terete, ascending from the base of the petiole, with sereral sheathing hracts, ereen spotted with crimson; flowering bract $\$$ inch long, menbranous, apjeulate. sheathing helow, green, tingred and spotted with crimson.

(Wary soch long. with six rounded angles, green, with small crimson spots.

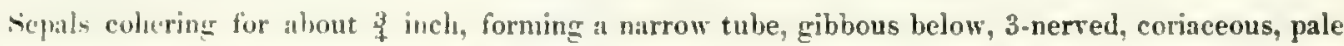
yollow. with mumerous small transterse crimson spots on the exterior, tapering into slender refiexed crimson tails, albont $2 \ddagger$ inches long.

l'etals about 1 inch long, linear, angled at the margin, apiculate, pale yellow, with a pale green apex and central line.

Lip ahout 3 lonerer than the petils, united by a hinge to the curved foot of the column, linear, nargins recurved, apex tri-lobed, pale yellow spotted with crimson, the apex covered with small papillix.

(olumn equalling the petals, apiculate, pale yellow, with the margin and foot bright crimson.

THIS very mare and interesting plant was discovered by $\mathbf{M r}$. Lehmann in 1876 , in the Enstern Andes of Loja. the most southern province of Ecuador. It was named by him and his friend Dr. Krinzlin, of Berlin, in allusion to the abrupty reflexed tails of the sepaks. The exact locality is stated by Mr. Lehmann, as follows:

I discovered plants of al. fractiflexa as long ago ats November, 1876 , but for many years I never saw the thwer. In December. 1s:tu, I found one flower only, and two years afterwards, I was so fortunate as to find at large mumber of flumts in flower. enabling me to make careful drawings and observations. As a specien it in very characteristic and casily to he distinguished, and, with its pretty and curious flowers, would deserve a place in any collection of Orehids.

(If all Masdevallias which I have observed, this is the rarest, and although I have spent many monthe in exploring every accessible part of the Eastern Andes. I have hitherto found comparatively fer specimens of it, and these mily in wu phace. This locality is called "El Dictamno," and is situated on the descent from the Lastern Andes, about halfowg between Loja and Zamora, at an elevation of 1,800 metres (5.hos foet). The plant srows on trees, from eight to sixteen feet from the ground, in very damp thick woods, and in a region where, during the whole year, there are very few days without rain.

Explanation of Plate, from a drawing ly. Mr. Lehmann:

Fig. 1. petal. lip, and 'olumm, nufurol size';-2, petal, onter side ; $-2 \Omega$, petal, from the inner side ;-

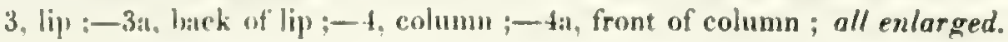







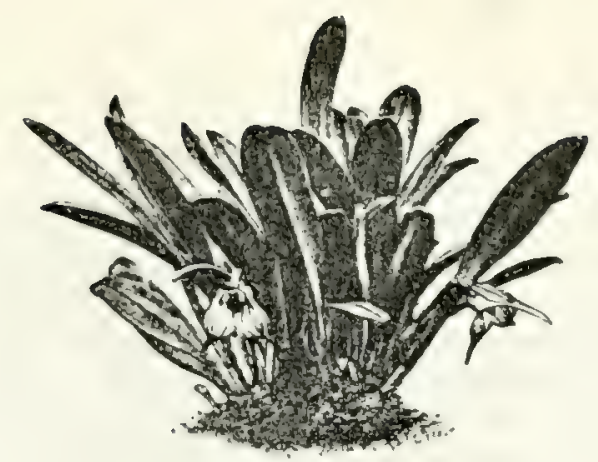

\section{MASDEVALLIA FRAGRANS, sp. nov.}

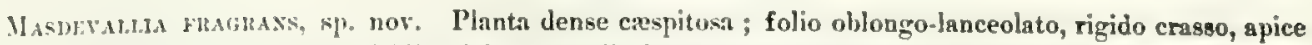
ahtuse trillenticulato, viridi pulchro, nervis lateralibus clarioribus, in petiolum robustum sensim :mentatto. hasi vaginato; pedunculo unifioro, tereti, erecto, viridi, rubro-maculato, multo curtiore yntin folio; pedicello pedunculo aequilongo, viridi pallidiore; bractea fusca nembranacea, supra 1Nala. infral amplexanti ; orario costato, glabro, riridi, rubro-maculato; sepalis in tubum extensum muntis. mento infra obtuso, triangulis, trinerviis, in eaudas carnosas planas elongatis, citrinis, ex. triopentis ruluro-maculatis, nervis sepali imparis rubris, sepalis lateralibus intus molliter pilosis, (anuli- tl: vis, viridi tinctis; petalis basi linearibus, supra oblongis, apiculatis, margine anteriore carnoso :u_nlatu, churneis, linea centrali rubra, apice riridi ; labello lingueformi, basi carnoso, glandulis duahus nectiriferis, apice verrucoso, flaro, minute rubro-punctato, lineis rubris tribus ; columns mhasta. alis ruluis an rustis, viridi, intus rubro-striata, apice minute denticulato, pede flavo, rubromisulato. Flos fragrantimimus et perelegans, qui 31 . porhyantha florem magnitudine prope :expat.- Sprecies nova sectionis Corincece Rclıb. f.-Hab. Ocaña?

Hinle of leat i or 6 inches long, 1 inch wide, oblong-lanceolate, thick and fleshy, apex bluntly trideaticulate, bright shining green. the principal nerves paler, narrowing below into a thick grooved petiole, sheatieal at the hase.

Peafunclo (with pedicul) 3 or 4 inches Jong, terete, ascending from the base of the petiole, green sputted with erimsun; pedicel alwout $1_{2}^{3}$ inch long, very pale bluish-green, with minute crimson spots on the outer sille: Inset ahout is inch long, ovate, shenthing below, dull brown.

(Wury nesty inch long. with six rounded angles, green spotted with crimson.

Sipnls: dorsil sepul nuited to the literal sepals for $\frac{1}{2}$ inch, forming a wide tube, gibbous below, free

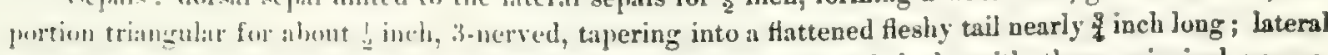
copal- colvering for alunt is inch, fice portion ovate-triangular for $\frac{1}{2}$ inch, with three pripcipal nerves, t:prering intu $甘$ colsy tail, incl long; all the sepals clear lemon.yellow, the tails tinged with canary-yellow and treen, the nerves of the dorsil sepal lright crimson, the iuner surface of the lateral sepals relrety with munerous short noft hairs.

Petals to inch long, linear at the base, oblong above, apiculate, thickened and angled on the anterior uaran, thich and floluy, shing ivory. white, with a broad crimson central nerre, apex greenish.

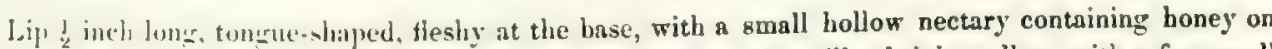
each side of the central nerve, anterior portion rough with small papille, bright yellow, with a few small crimson spots and tluree dull crimson lines.

Colum 3 inch long, steut, warrowly winged, apex slightly denticulate, pale green, with crimson lines within and with crimson on the wings and apex, foot bright yellow, with small crimson spots.

Fixplanation of Plate, drawn from a plant at Newbattle Abbey :

Fig. 1, petal, lip, and column, in natural position;-1a, section of orary ; -2 , petal, inner side; 3, lip ;-3a, basc of lip, showing nectaries (much enlarged);-t, column;-4n, apex of column ; all eslurged; -5 , njex and section of leaf, natural size. 
NO certain information can be given as to the habitat or the discoverer of thim new species. It was purchased from Mr. Bull in 1887, for the Marqueso of Lothiatis collection, under the name of $M$. elephanticeps, and until the first flowers appeared, in April 1892, no suspicion of the incorrectness of this name was entertained, the grent resemblance between the leaves of the two species justifying those who named the plant. That the flowers of $M$. fragrans do not resemble those of $M$. clephanticrps need handly be pointed out; the shape and size of the massive flowers of the latter, with the ir long taik and the dark colouring of their lateral sepals, are sufficient to distinguish the ino at a glance.

The habitat of $\boldsymbol{M}$. elephanticeps is Ocana, in the proviuce of Santander, Colombia. where it grows in woods at an elevation of 6,000 to 10,000 feet. Mr. Bull's plants of M. elephanticeps were imported from that locality, and there seens to be little doulst that $M$. fragrans was introduced among them, the two probably growing together, and, when not in flower, so closely resembling one another as to be indistinguishable.

The delicate fragrance of the flowers-an uncommon characteristic throughout the genus Masdevallia-suggested our specific name for this plant. 



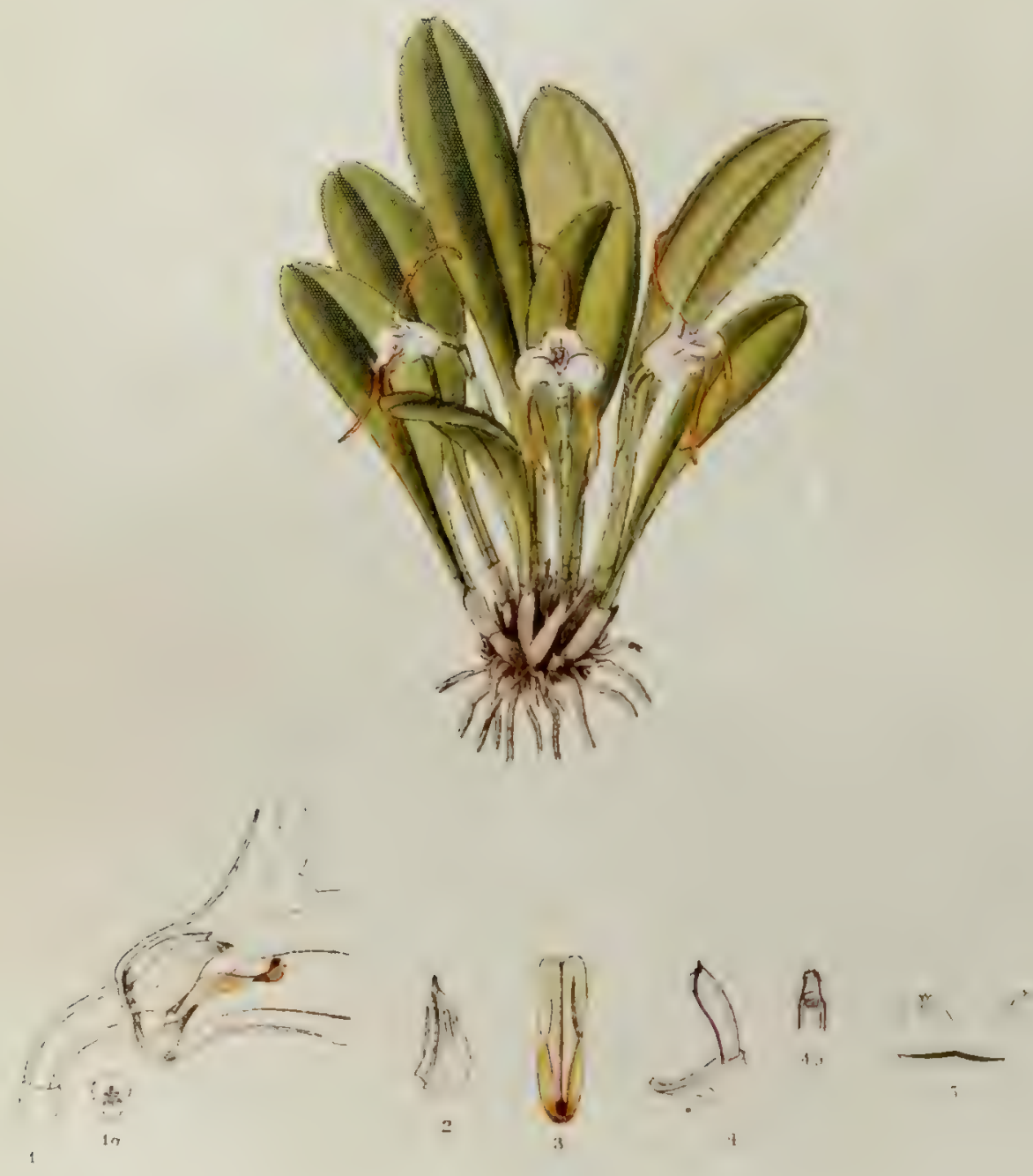

MASDEVALLIA LAUCHEANA KrMnZ MS 


\section{IISI)EVALLIA LACCHEANA Kränz. MS.}

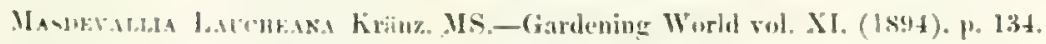

Panta cappitasit folio oblongo-nato, apice acute denticulato, nervoso, viridi heido, in petiolum

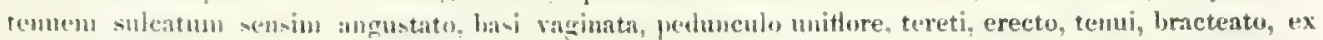
vagua shunl latsen petioli emerenti. viridi; bractea menbrabacea, supra ovata, apiculatu, infra

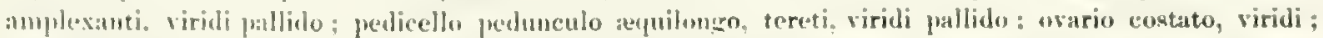
oppalis in tubun comstrictum connatis, mento infra rotundo, triagulis, cueullatis, trinervie, in caudas

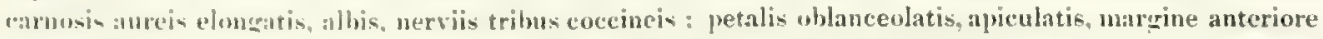

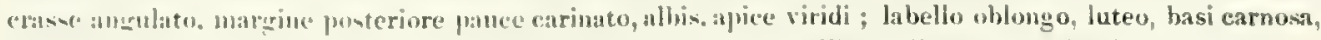
carinin fublus angulatis parallelis, in pulvilum coccinem molliter pilosum terminatis, apice minute asperu, sureo: colum temu. anguste alata, alba, coccinea-narginata, apice denticulato.-Flos formam illins. 1\%. Mragenerione hahet.-Ineognitum est qua habitet et quis collegerit.

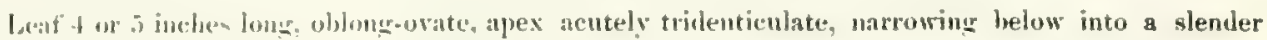
atooverl petiole sheathed at tho balse, bright green.

I'efunche inhut 2 inches long. terete, slender, erect froin the base of the petiole, pale green; bract marly $!$ inch lone. wate-ap)indate. sheathing below, with a minute rudimentary bud within at the base, pailes incent.

Wary i inch longr. curved. with six rounded angles, pale green.

vicpals all colvering fir abus 3 inch, forming a narrow tube, qribbous below, free portions roundly tribngular, ä-nerved, pure white, each with one rose-crimson streak, and all terminating in terete bright nomentails nearly I inch long.

l'etals less than I inch Jong, ohlanceolate. witl a thick angled keel on the anterior margin and a small che ncar the opposite side. acminate, pure white witl a green apex.

Lify lomere than the petals, thichened at the hase and united hy a hinge to the foot of the colum, with two angled homgitulinal heek, terminating in a velvery crimson cuslion, pale yellow. apex slightly cremate. urange-yellow.

(o) edere of dark crinisun.

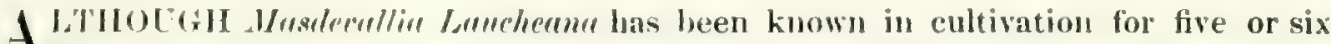
fear, no drawing or botanical description of' it has hitherto been published. 'It " nam ned by Mr. Krinzlin. of Berlin. in honour of his friend Herr Lanche, of Eisgrub, Instria. I can obtain no information as to its origin or habitat. A very pretty variety in prown in sir Trevol Lawrence's collection of Masdevallias, which has a rose-coloured spot upon the angle of the dorsal and lateml sepals, and three streaks of the same colour upm the lorsal sepal. "The tails of this flower are of a richer orange than those of the type and the lip is very pale rellow.

Lixplauation at" Plate:

Fig. 1, petal. lip. and colum, in uatural position;-1a, section of ovary;-2, petal, inver side ; -

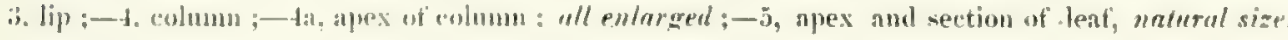






$$
\text { V }
$$




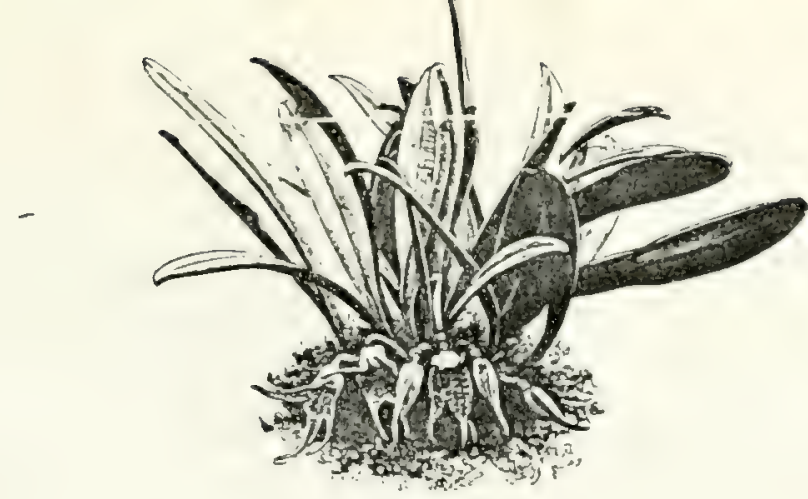

\section{IIASDEVALLIA LEONTOGLOSSA Rehb. f.}

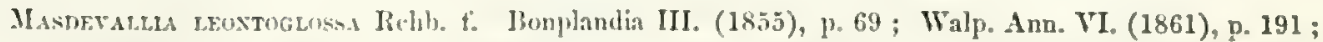
Gard. Chron. 1S\$1, jt. I.. p. 234; jt. II., p. 336 ; 1885, pt. II., p. 429 , fig. 92 ; Veitch Manual (Brch. pt. V. (1s\$9), p. 49.

Leaff $f$ ur $x$ inclies long, about 1 inch wide, linear-lanceolate, coriaceous, obtusely tridenticulate, dark sreen, spotted on the base and margin with crimson, narrowing into a grooved petiole sheathed at the base.

Peduncle $1 \frac{1}{2}$ or 2 inches long, thick, terete, with two or three sheathing bracts, pale green spotted with bright crimson, descending from the base of the petiole; flowering bract 5 inch long, 3.nerved, owate, closely sheathing near the base, rery pale green spotted with crimson.

Orary 3 inch long, with six rounded angles, green spotted with crimson.

Sepals: dursil sepal united to the lateral sepals for $\frac{1}{2}$ inch, forming a wide tube, free portion triangular for with crimson on the outer surface and covered with short rigid lairs within, tapering into a fleshy tail $1 \frac{1}{2}$ inch long, greenish, with suall crimson spots; lateral sepals cohering for about 1 inch, orate. trinugular, 5-nerved, semi-trnnsparent, pale greenish-yellow, the inner surface covered with short rigid hairs and heavily spotted with crimson, tapering into flesly titls $\$$ inch Jong, green, vith a few small crimisun spots.

Petals about to inch long, linear at the lase, ovate above, anterior margin angled, with a prominent Heshy lobe on the inner surface, whining white, with one or two crimson streaks.

Lij 5 inch long, united to the foot of the column by a rery flexible hinge, grooved in the centre, with a decll nectary on each side at the hase, anterior portion tongue-shaped, whitish, covered with crimson syots, and rowglt with suall papilla, apex dark crimson, covered with papille.

Column b incl! long, winged. shining white, spotted on the foot and edged with dark crimson, apex minutely denticulate.

$\mathrm{M}$

ASIEVALLIA LEONTOGLOSSA was first deseribed by Professor Reichenbach in 1 15is, from dried specimens collected by Hermann Wagener in the neighbourhood of Pericos, in New Giranata, at that date one of the three great Republics of Colombia. It first flowered in cultivation at Brussels in 1867, in the collection of Mons. Linden. The downward growth of the short, thick flower-stalks distinguishes it from allied species, and the nectaries at the base of the lip secrete hones in greater abundance than those of any species which I have examined. The lip curiously resembles

Explanation of Plate, drawn from a Plant at Newbatte Abbey:

Fig. 1, pretals, lip, and colum, in natural position ; - la, section of oxary ; - 2, petal, inner side ;-

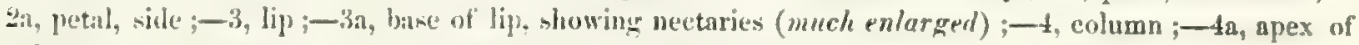
column; "ll eularged; - 5, apex and section of hị, nutural size. 

the tongue of a lion in shape and in the roughness of its surface, and doubtless sugrgested to Professor Reichenbach the specific name leontogloasa.

Cousul Lehmam adds the following information :

Masdecullin lemetoglosen is found in Colombia, where it grows ons trees, and rarely on the ground, in the vicinity of Ocaña, at an elevation of 1,800 to 2,300 metres $(5,850$ t1 7,475 feet). The temperature of this region is $15^{\circ}$ to $18^{\circ}$ Centignde (59 to $64^{\circ} .4$ Fahrenheit).

F. C. LehmanN. 




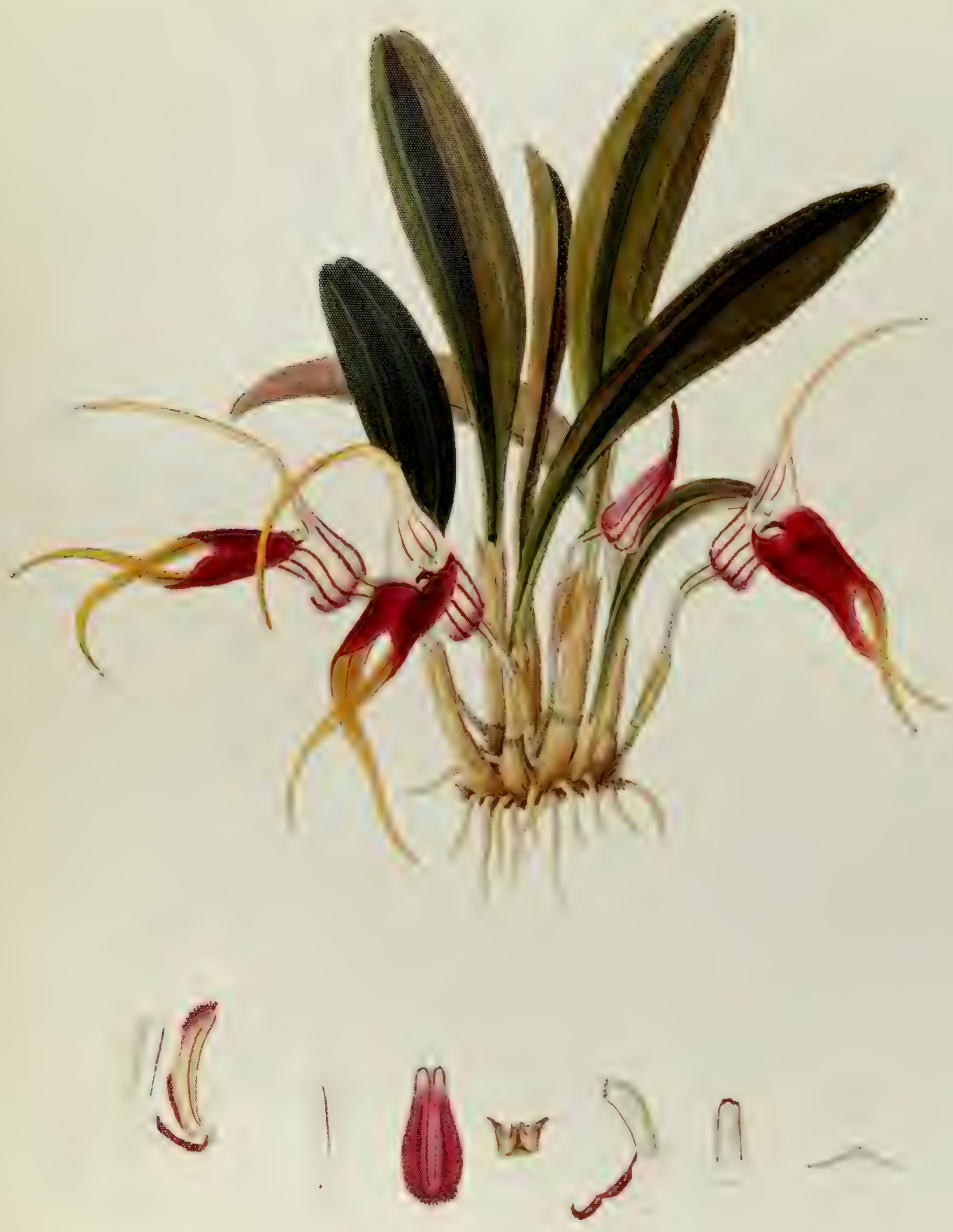




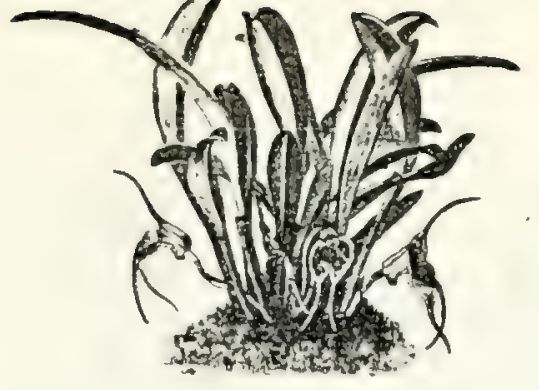

\section{MASDEVALLIA MOOREANA Rchb. f.}

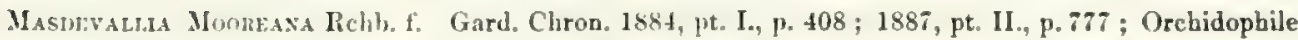
(Godefroy), 18s4, p. 134; 1888, p. 262 ; Bot. Mag. t. 7015 (1888); Veitch Manual Orch. pt. V. (18s9), 1. 53.

M. elephlentireps var. pachyseprala Relıb. fo Bonplandia II. (1854), p. 283; Xen. Orch. I. (1858), p. 198, t. it, figs. III. and IV.

M. smmorcula Rebb, f. Gard. Chron. 1887, pt. II., p. 713 ; Orchidophile (Godefroy) 1888, p. 230.

Leaf alyout 5 inches long, oblong, obtusely tridenticulate, coriaceous, curved, narrowing below into a stout grooved pretiole, sheathed at the base, dull purple-green, the young leaves bright shining green, with a faw dull crimson spots upon the petiole.

P'eduncle scarcely more than $\frac{1}{2}$ inch long, with a pedicel 1 inch long, terete, with two sheathing bracts, ascending from the hase of the petiole, green, with sunall crimson spots; flowering bract $\frac{3}{4}$ inch long, apiculate, sheathing helow.

Orary 3 inch long, with six rounded angles, dull green.

Sepals : dorsal sepal united to the lateral sepals for about $\frac{1}{2}$ inch, forming a wide tube, gibhous below, free portion ovate-triangular for $\$$ inch, 3-nerved, tapering into a flattened fleshy tail 2 or $2 \frac{1}{2}$ inches long, pale greenish-yellow, with crimson nerves and yellow tail; lateral sepals cohering for about $1 \frac{1}{2}$ inch, oblong-ovate, 3-nerved, rich purple-crimson, the nerves darker, covered with papillæ, and tapering into flattened tails nearly 2 inches long, usually crossed, pale yellow shaded with crimson.

Petals about in inch long, oblong, apiculate, much thickened on the anterior margin, white and shining, with a rich crimson central streak.

Lip: : little longer than the petals, tongue-shaped, rrooved and fleshy at the base, and united to the curved fout of the column by a flexible hinge, purple-crimson, with darker longitudinal lines, the apex covered with stift dark hairs.

Column shorter than the petals, narrowly winged, apex denticulate, green, the apex, margin and foot crimson.

THERE has been much doubt as to the specific distinctness of M. Moorema, and frequent confusion between it and $\boldsymbol{M}$. elephanticeps. I have no hesitation in identifying it with Reichenbach's $\boldsymbol{M}$. elcphanticeps ver. pachyscpala, although it is difficult $t 0$ acconnt for the fact that he afterwards named the same plaut $\boldsymbol{M}$. Mooreana. Thirty years, however, elipsed from the time (1854) when he published the earlier name, with a very scanty description of dried specimens sent to him from Ocaña by Warscewicz, until the date of his eximination of the specimens which he named $\boldsymbol{M}$. Mooreana-fresh flowers produced from cultivated plants. In 1858 a more detailed description of the same plant was given in his "Xenia Orchidacea" from a coloured drawing sent to him by Wagener with specimens preserved in alcohol. A comparison of Wagener's drawing

Explanation of l'late, drawn from al plant at Newbattle Abbey:

Fig. 1, petal, lip, and column ; - la, section of ovary ; -2 , petal, inner side ; -3 , lip ; $-3 a$, base of lip showing nectaries: -4 , column; $-4 \mathrm{a}$, apex of column; all enlarged; -5 , apex and section of leaf, naturul size. 


$$
\text { - }
$$


(Pl. 74 Xen. Orch. I.) with specimens of M. Moorenue and M. Alephemticeps shows that it much more nearly resembles the former than the latter, of which an unmistaktalble figure is given at Pl. 3 of the same volume. The long, unspotted, strongly-veined tube of M. elephanticeps, its oblong lateral sepals tapering into narrow tails, and especially the unstriped, bright yellow dorsal sepal, clearly distinguish it from vor. pachysepalu ( $M$. Moorena), with its short spotted tube and wide flattened tails, and the three conspicnous crimson streaks upon the dorsal sepal.

In describing $M$. Mooreana in 1884, Reichenbach gives no locality or dincuverer's name. Accepting it as identical with $\boldsymbol{M}$. elephanticeps var. pachysepuli we must, therefore, turn to his account of that plant for information as to its labitat. He states that it was found by Warscewicz, Wagener, and Schlim, in woods near Ocaña, at an elevation of 7 to 8,000 feet.

The plaut named by Reichenbach in $1886 \mathrm{M}$. sororcult, cannot be considered specifically distinct from M. Mooreana. The flower is rather smaller and more slender in shape, and the wings of the column are a little wider. The yellow of the sepals is slightly greener in shade, but the colouring is otherwise identical. 





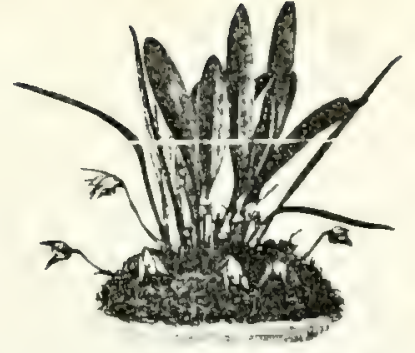

MASDEVALLIA ORTGIESIANA, hort.

\author{
Makmivalta Ohtgifsiana, hort. Orchid Review vol. III. (1895) p. 48.
}

I'Janta dense caepitosa; folio lineari-lanceolato, rigido, apice tridenticulato, riridi, in petiolum rubustum sulcatum scusim angustato, basi vaginata, pedunculo unifore, tereti, erecto, bracteato, tenuissimo, multo curtiore fuam folio. ex basi petioli emergenti, viridi, minute rubro-punctato; pedicello curtio, tereti, viridi pallido, ruhro-maculato; ovario curvato, costato, virjdi, rubro-maculato; sepalis in tubum ve crathum connatis, urento infra rotundo, oratis, trinerviis, in euspides obtusas planas terminatis, churneis $\mathrm{vl}$ allis, roseo-tinctis, nervis minute rubro-maculatis rel striatis, cuspidibus viridibus; petalis Ianceolati, acuminatis, albis, apree viridi; lalyello obovato, recurvato, basi sulcata, margine anteriore erenato, apice verrucoso, alho, lineis roscis tribus parallelis; columna curta, anguste alata, alba, apice tridenticulato.-Flore minore quam illo $\mu$. striatella, sed illi affini.-Incognitum est qua habitet et quis cullegrerit.

L.a f about 4 inclies long, linear, stift and Heshy, tridenticulate, narrowing below into a stout grooved petiole, sheathed at the base, green.

l'eduncle 2 inches Jong, terete, very slender and wiry, with two sheathing bracts, erect or semilateral frum the base of the petiole, green, with minute crimson spots; flowering bract $\frac{1}{4}$ inch long, membranous, ajiculate, sheathing below, brownish.

(Gary abutt $\frac{1}{k}$ inch long, curved, with six rounded angles, pale green, with minute crimson spots.

Sepals about $\frac{1}{2}$ inch long, all cohering almost equally for $\frac{1}{8}$ inch, forming a wide open tube, rounded below, free portions oblong-ovate, 3-nerved, ivory-white or pale pink, with a few rose-coloured spots, especially along the nerres, and all tapering into flattened fleshy green points.

l'etals :hout $\frac{1}{3}$ inch long, linear-oblong, apiculate, white, apex green.

Lip longer than the petals, thickened and grooved at the base and united by a hinge to the foot of the colum, oviloblong, white, with three rose-coloured lines, anterior portion covered with asperities, pintisl.

Column much shorter than the petals, winged, white, apex denticulate.

THROCGH the kindness of Mr. F. W. Moore I have the opportunity of publishing a drawing of the only known plant of Mnstlexnllin Ortyicsiann, and although I have encleavoured in every way to ascertain its halitat and discoverer, the information which I have been able to obtain is of the scantiest. In 1891 the plant was purchased by Mr. Moore from Messrs. Seeger and Tropp-a firm which has now ceased to exist-and they had received it "from the Continent." Even Mons. Ortgies, of Zürich, after whom the plant is named, and to whom I have applied for information, can tell me nothing of its origin, or of the anknown friend who named it in his honour. No botanical description of the species has hitherto been published, and only a short account of it is given in the Orehid Review for Feb. 1895, of flowers from Mr. Moore's plant. The nearest ally of $M$. Ortgiesimu is $M$. strintolla, but in that species the large development of the lip and petals in proportion to the size of the sepal-tube is rather less remarkable. In neither of these two little plants-the suallest of their group-is there any sign of a sectary at the hase of the lip, and in placing them in the Section Corincen I am following Professor Reichenbach, who classed $\boldsymbol{M}$. striatelle with $\boldsymbol{M}$. compyloglossa.

The woodcut is taken from a photograph kindly supplied by Mr. Moore.

Explanation of I'late drawn from a plant in the Royal Botanic Gardens, Glasnevin, Dublin :

Fig. 1, petal, lip, and column, in natural position;-1a, section of ovary ;-2, petal, inner side ; 3 , lip; -4 , column; - ta, apex of column; all enlarged; -5 , apex and section of leaf; natural size. 



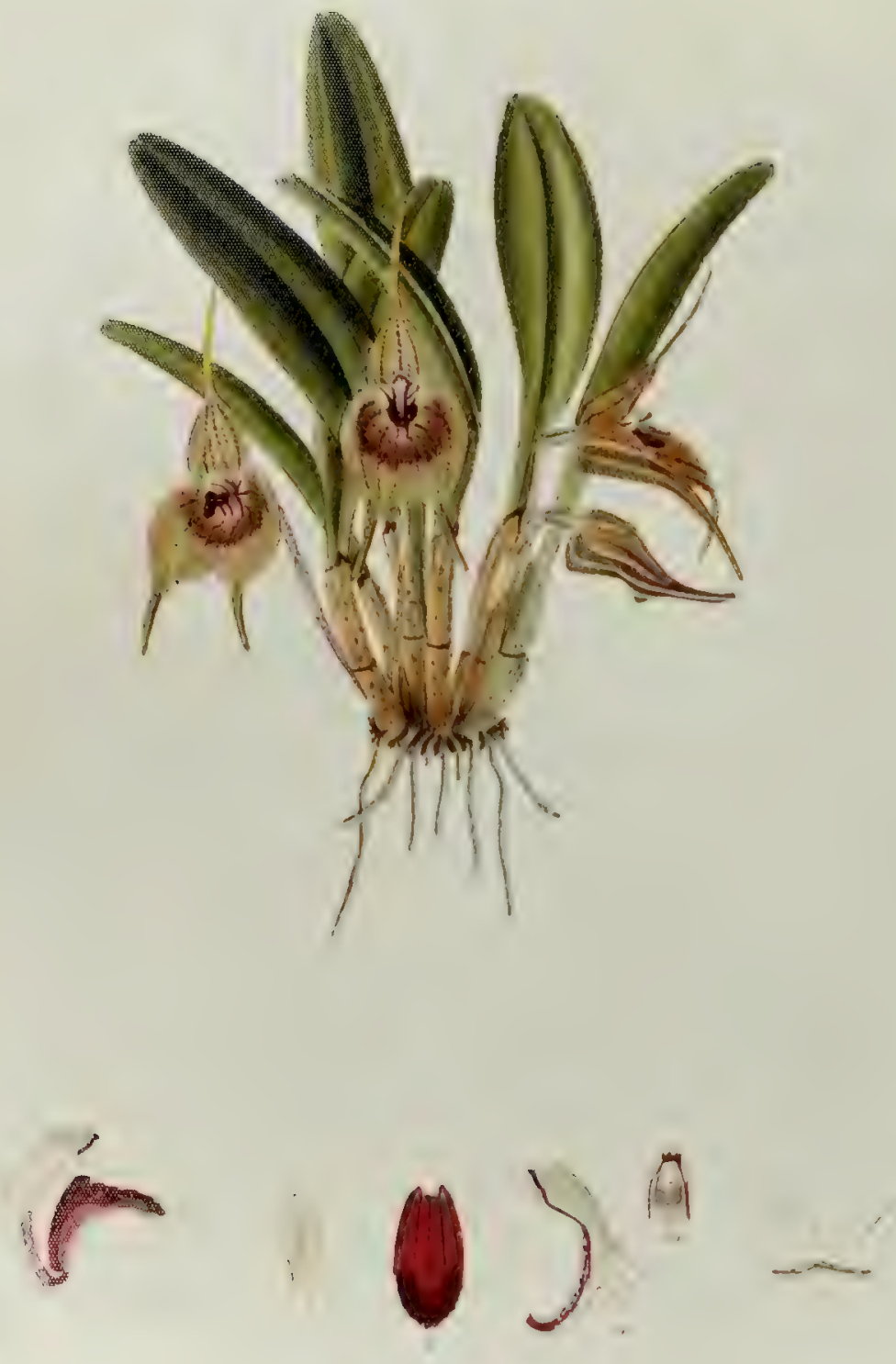


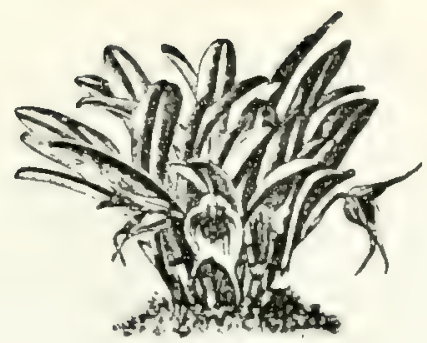

MASDEVALLIA PACHYANTHA Rchb. f.

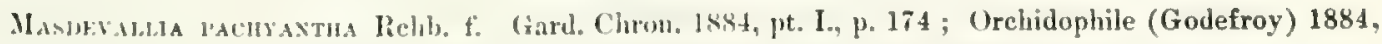
1. 100; Flora (Singer) 1\$86, 1).561; Veitch Manual Orch. V. (1889), p. 56.

locat 4 or in inches long, oblongrovatc, obtuncly tridenticulate, coriaceous, dark green, narrowing lowow inten a thick grooved petiole, sheathed at the base.

Peduncle abut : inches long, including the pedicel, which is nearly 1 incls long, terete, with two

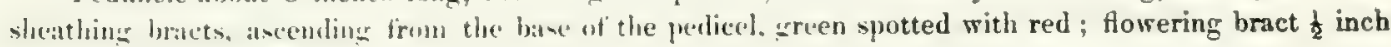
lenge, membranons, apiculate, shenthing, brownish.

(bary f incly long. with six rounded angles, very shining, pale green tinged with brown.

Sepals: dorsal sepal united to the lateral sepals for 1 inch, forming a wide cup, free portion trimgnl:ar-wrate for ahout \& inch, 3-nerved, tapering into a slender fleshy tail 3 inch long, honey-yellow, a(mi-tram-parent, with numerous minute crimson dots and crimson nerves, tail bright yellow; lateral sepal-collering for nearly 1 inch, giblous below, brondly orate for 9 inch, 3-nerred, terminating in thatenced rails is inch long, honey-yellow covered with soft minute amethyst-crimson hairs and spots, especially upon the nerves, tails dull green.

Petals about 3 inch long, orate-ublong, thickened at the margins, very shining, with viscid matter within near the base, apiculate, pale yellow, with one crinson central streak.

Lip! ! inch Jong, oval-oblone, much curved, very thick and fleshy, with two very thick keels or ridges terminating half way, dull mottled crimson, apex rongh with papillz, dark crimson-purple.

Column g inch long, narrowly winged, green, edged with crimson, apex denticulate, crimson.

$\mathrm{M}$

ASUEVALLIA PACHYAXTHA was first described by Professor Reichenbach in 1sist, from specimens sent to him by Messrs. Carder and Shuttleworth, in whose collection it fowered for the first time in cultivation. Whether the original discoverer of this specie's was Mr. Crosi or Consul Lehmann seems uncertain, for Reichenbach stites that he had specimens "a long while ago," collected by Mr. Cross; adding, "Lehmann also wrote to me about it long ago."

In the British Museum of Natural History there are dried specimens collected by Mr. Lehmam in 18si on the western slopes of the Central Cordilleras of Popayan, at an clevation of $3,000-3,500$ mitres (9,500 to 11,375 feet), and others found by him in 1882, growing upon trees in (lamp) mountain woods on the western slopes of the Paramo de Moras, at an clevation of 3,000 metres.

The phant here represented is rather a small specimen, and in the collection at (ilasnevin, Dublin, both leaves and fower-stalks attain a greater length.

Foxplamation of Plate, drakn from a plant at Newbattle Abbey :

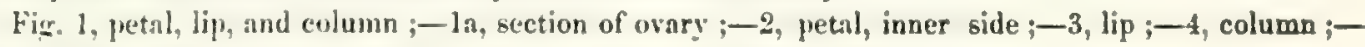
t:t. apex of column; all enlarged; - 5 , apex and section of lenf, natural size. 


\section{Mr. Lehmann sends the following note:}

Masdevallia pachyantha is restricted to the western slopes of the Contral Anden of l'uparim and Pusto, from $1^{\circ}$ to $3^{\circ}$ north of the equator, at an elevation of $2,9(10$ to 3,300 mitres (9.42.) $1010,72.5$ fic. $t$ ) It grows on trees in the thick damp forests of the upper Andes, and also on walls of rolcanic rucks form. ing the sides of steep mines. With the exception, perhaps, of $M$, racemosa, it is the commonest of all Masdevallias, sometimes entirely covering the trunks of trees from the zround up tu a considerable height. I have observed it on the slopes of the Prirnmo de Moras, and on the Piramo de las Delicias and Guanicats. upon the volcano of Purace, in great abundance on the Phramo de Barhillas, on the volcano of Tajumbina, and in numerous other localities.

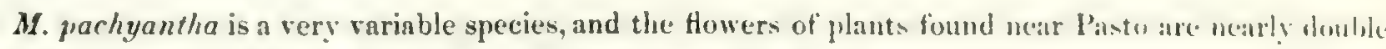
the size of those growing on the voleano of Purace, and are heavily lotehed-not streathed-with darh purplish-brown. The largest plants and flowers come from the Paramo de barbillas, and the fincl!

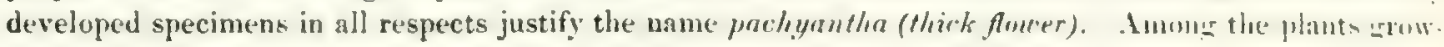
ing on the Páramo de las Delicias and Guanacas there is a variety with rather small pale yellow Henwe.

The climate of the habitat of $M$. prachyancha is remarkable for its excessive and continual diumpun... with a clouded fogey atmosphere and extremely cold winds. There in only a short interval, frum danuan! until March, when little or no min falls, and at this time instend of min dense fogs prevail, risin! jun ahove the forests and enveloping them in constant mist and twilight. Dhuing the rest of the veir there. are heavy rains, with sharp east winds, the temperature often falling as low as $1^{\circ}$ ahowe zoro Centingude

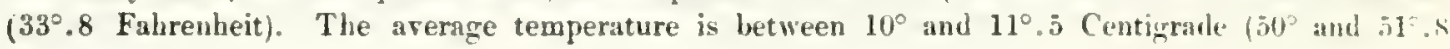
Fahrenheit).

As a wild plant M. puchyontha flowers most profundy, often lanting from september until Ma!. 





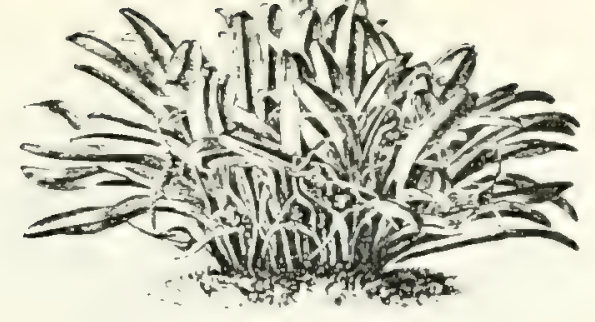

\section{MASDEVALLIA PERISTERIA Rchb. f.}

Masmilalia Pfristris Rchb.f. Gard. Cliron. 1874, pt. I., p. 500 ; 1881, pt. II., p. 336 ; Bot. Mag., t. 6159 ; Flore des Serres, 1877, vol. XXII. t. 2346; Illustr. Hort. 1878, vol. XXV. ser. 3, t. 327, p. 152.

Leaf about 5 inches long, linear-lanceolate, thick and fleshy, tridenticulate, narrowing below into a slender pretiole, dark green, sheathed at the base.

Peduncle 2! inches long, terete, ascending from a joint near the base of the petiole, with two shenthing bracts, pale green, sometines spotted with crimson; flowering bact $\$$ or $\$$ inch long, $3 \cdot$ nerved, sheathing below, orate and apiculate above, pale green or brownish, and having within at the base a small rudimentary flower-bud.

()rary l, inch long, curved, with six rounded angles, bright green and shining.

Sepals: dorsil sepal united to the lateral sepals for about 3 inch, forming a wide tube, gibbous benenth; lnteral sepals cohering for nearly $1 \frac{1}{4}$ inch; all triangular-orate, 3-nerved, greenish-yellow with numerous dark crimson spots, and tapering into fleshy tails about if inch long, flattened at the base, triyuetrons towards the apex, yellow, greenish at the back.

Petals about $\frac{1}{2}$ inch long, oblanceolate, curred, fleshy, shining, pale green, sometimes with a few brown sjots, apex minutely denticulate, anterior margin slightly keeled, with colourless viscid matter henenth.

I.ip $\frac{1}{2}$ inch long, pandurate, base Heshy and deeply grooved, with a small concave nectary on each sille. centre with two longitudinal elevated lines, and two rugose lateral keels, greenish white, spotted and m:nrinel with deep purple, spex much reflexed, crenate and rough with numerous dark crimson papilla.

(olumm nearly \& inch lone. broadly winged, attenuate below, green, foot rich crimson, apex white. liglity denticulate.

THERE appear to be two or three varieties of Maslevallin Peristeria, although none

of them are very strikingly distinet in their characteristics. Consul Lehmann informs me that the oritrinal form deseribed by Professor Reichenbach (Gard. Chron. 1sit, pt. I., p. 500 ) is not now in cultivation, and that it differed from the variety universally known in collections and firured in the accompanying plate, in having more brightly coloured flowem and longer tails. A coloured sketch in my possession, drawn Iy Comsul Lehman in the actual habitat of the plant, of the variety which he considers to have becen the first introduced into Europe, represents the flowers of a bright golden yellow spotted with crimson-purple, and having yellow tails nearly two inches long and more slender than those of the best-known variety.

11. Perigterin was first imported from Colombia in 1873, by Gustav Wallis, while collecting for Mesms. Veitch, who supplied Professor Reichenbach with the fresh flowers named and deseribed by him in 1874. On referring to Mr. H. Veitch for information renpecting the appearance of these first imported plants, I cannot, however, learn that they differed in any way from the variety now in cultivation.

Profensor Reichenhach appean to have suspected the existence of two varieties of .Y. I'rristrin, for he remarks (Gard. Chron. 1874, pt. I., p. 500) : "If this plaut has ever been observed before, it was hy my friend Wagener, in Venezuela. I bave a sketch of 
his much like this, but, since no specimen was added, I, of course, never named it. Th. tails of the perigone, however, are represented as green, and the flower is much smaller." This description agrees well with the appearance of a small variety now in cultis ation in the Royal Botanic Gardens at Glasuevin, Dublin, a specinen of which has leen hindls sent to me by Mr. F. W. Moore for examination, with the information that the plant

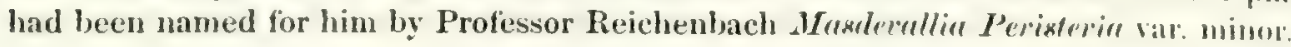

The locality first mentioned by Consul Lehmann in the following note in. he inform me, the habitat whence plants of $\boldsymbol{M}$. Peristerin were fint imported to Europe. The second locality mentioned is the habitat of the plant now known in cultivation, to which he refers as "A peculiar variety."

Masdevallin Peristerin Rchl). f. grows on trees in park-like woods near Caldas, Icar Medellin, and also about Carolina in the department of Antioquia, at an clevation of 1,800 to 2,200 metres $(5,850$ to 7,150 feet). A peculiar variety grows about Pusurfuatr, on the road from Tuquerres to Barbacoas, in the southern part of the department of the Cauca, at an elevation of 1,600 metres (5,200 feet).

The plant grows most commonly near the ground on the trunks of trees, chictly ontis, in open woods or by the river-sides, where a free circulation of air takes place. It attains its largest development when growing on the decayed trunks of oak-tlees lying on the ground. Its appearance is confined to small areas, but wherever it is to lx found it grows in great abundance. In some localities, farourable to the requirements of the plants, fully one half of the flowers produce seed-pods, while in lest congenial localities seed-pods are very rarely to be met with.

In Antioquia M. Peristerin flowers from Octolser to December, and in the Canca in January and February.

\section{F. C. Lehмахх.}

Explanation of Plate, drawn from a plant at Newlattle Abbey:

Fig. 1, petals, lip, and column, in natural position ; - la, section of orary ;-2, petal, iuncer side:- 3 , lip;-3a, apex of lip; all enlarged;-3b, base of lip showing nectaries, much enlarged ; -4 , colum ;ta, apex of column; enlarged;-5, apex and section of leaf, natural size. 



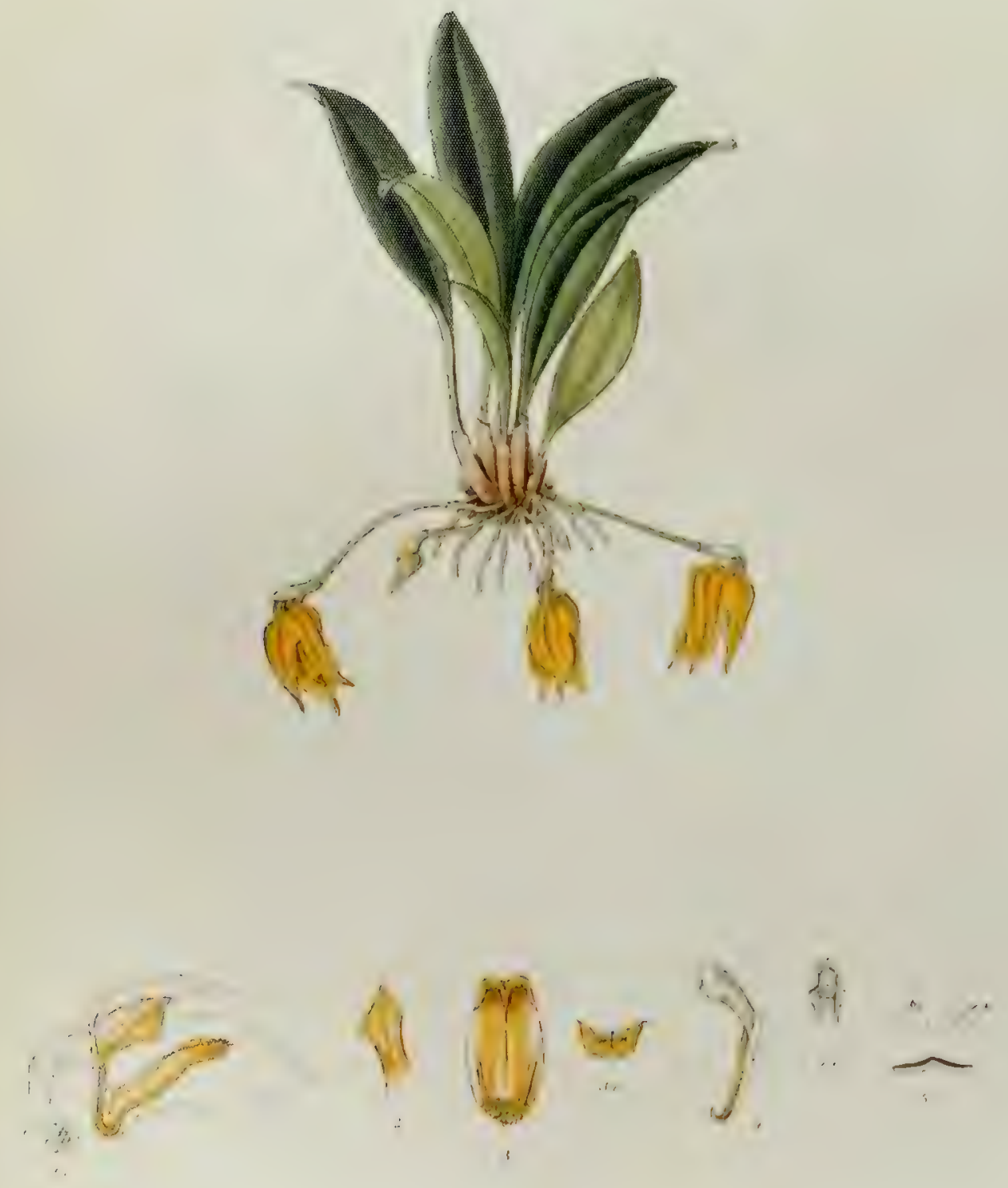


\section{MASDEVALLIA PLATYGLOSSA Rchb. f.}

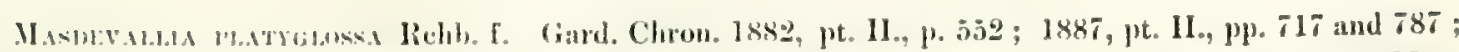

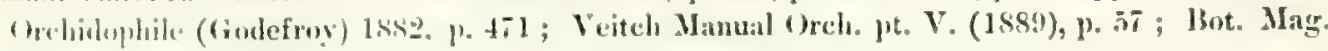

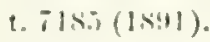

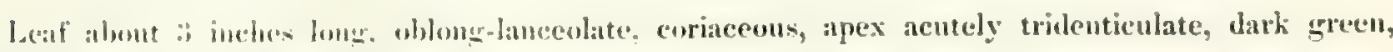

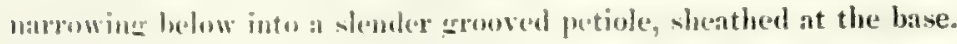

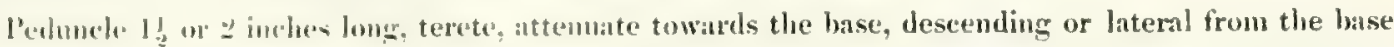
of the fretioles with two on thee sheathing bracts, pale green; Howering bract 3 incis long, membranous, sheathing helow: ample albores, concealing the short pedicel and the base of the ovary, with a minute molimantary but within at the base, very pale wreen.

Won? I inch long, wrved, with six rounded angles, pale green.

Sepals: dursal replal united to the lateral segals for about \& inch, forming a wide tube, giblous

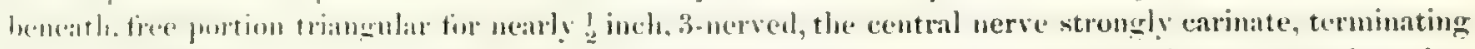
in at hlunt Hesly tail it inch long : lateral sepals cohering for 3 inch, free portions ovate-triangular, 3-nerved, terminating in blunt tails or points searcely 1 inch long; all lemon-yellow, with pale green merven the surface slightly velvety.

l'ctals nearly a inch long. oblong at the base, trimgulat at the apex, the anterior angle much prolonged. Hewly, shining. pale clear vellow, with a greenish central line.

Lif more than s inch long. united to the foot of the colum by a Hexible linge, hase growed and

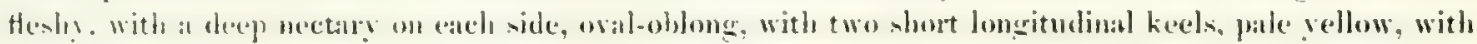
darkiar nerves, the apex eovered with large acute papillat.

(o) чprealing. white.

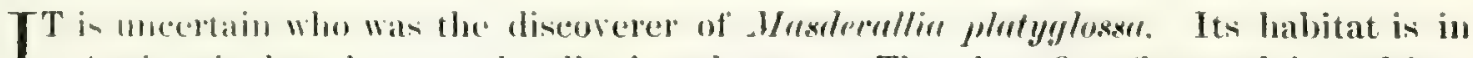
dutioguia. hut the esact locality is unkmown. The plant first flowered in cultivation in the collection of sir 'Trevor Lawrence, in 1682, and was named by Professor

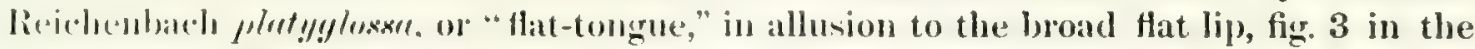
accompanying Plate. 'This fouture is unusually large compared with the other parts of the flower, and is espereially rematiable for the ereat development of the nectaries at the bises.

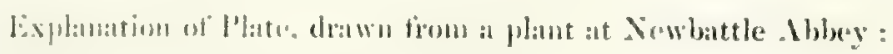

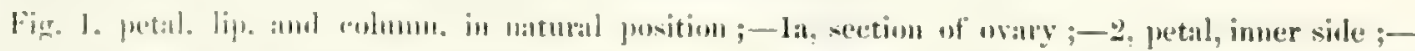

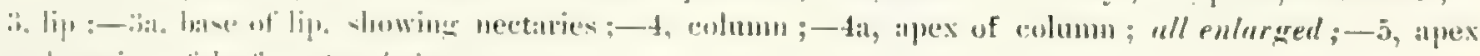

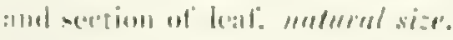




V. 


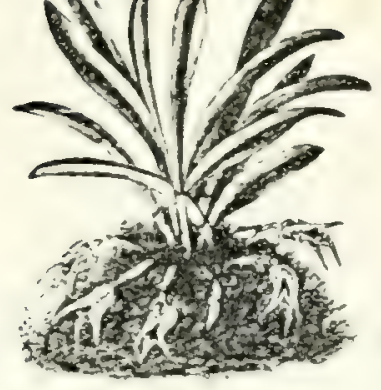

\section{MASDEVALLIA PORCELLICEPS Rchb. $f$}

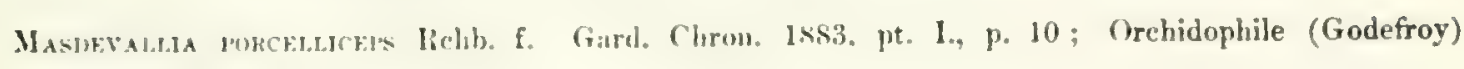
$1 \times 83$, p. 567 .

Leat alout sinclue lome, whlong-lanceolate, ohtunely tridenticulate, very coriaceous, narrowing below into at arowred petiole, sheathed at the base, dark green.

l'eduncle. inchuling the pedicel, albont 1 ! inch long, terete, lateral from the base of the petiole, with

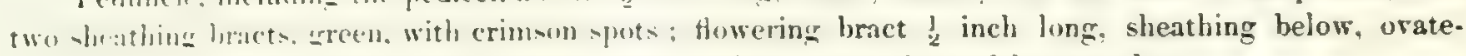
acuminate above, pale green, spotted with crimson when young, brownish-green later.

W Mary il lunt $\frac{1}{3}$ inch long, curved, with three romded and three flattened lobes, pale green, with a few crimacon -prots.

Sepratu: dossal sepal united to the lateral sepals for sather more than $\frac{1}{4}$ inch, forming a narrow tube, griblum at the base. free purtion oblongrtriancular. tapering inte a flattened fleshy tail about $\frac{3}{8}$ inch long: lateril sopals cohering for nearly $\frac{3}{8}$ inch, oblonerovate, tapering into fleshy tails $\frac{1}{4}$ inch long; all 3-nerved, the principal nerves prominent on the outer -urface, pale yellowish-green, covered with crimson spots. chicfly upon the inner surface, which also shows numerous patches of crimson hairs.

Petals nearly 3 inch lomg, ohlongrovate. angled on the anterior margin, pale green, with one short crimson streat in the centre.

Lif nearly I inch long. united to the foot of the columm by a Hexible hinge, tongrue-shaped, with a lwilum neet:ry on each side of the bane contaning nuch honey, whitish or very pale green. with crimson spots alung the sides. and having two obscure laternl keels terminating in an oval cushion at the apex, which is crimson and covered with minute papilla.

Cohmm Nont and stout. narrowly winged, foot curved, apex denticulate, pale green winged and tipled with crimson.

THIs small species, one of the least interesting and attractive of the genus, was first dencribed by Professor Reichenlach in 18R3. from specimens sent to him by Mr. James O'Brien.

The name "porculliceps" was chosen by Rejchenbach on account of a fancied rescmblance in the shape of the buds to that of a young pig's head. In general appearance and in the downward or lateral growth of the flowers it is closely allied to 11. Imuloglosan, and lut for extain specific differences it might almost be taken for a miniature form of that species.

1 am unable to obtain any information as to its habitat.

Explanation of Plate drawn from a plant at Newbattle Abbey:

Fig. 1, petil, lip, and colmun, in natual position;-1a, section of ovary ; - 2, petal, inner side ;3, lip :- Bat, tane of lip. showing mectaries much enlarged);-4, column;-4a, apex of colunn; all enlurgel; - - a.j. apex and section of leaf, natural size. 





\section{MASIEVALLIA STRIATELLA Rehb. f.}

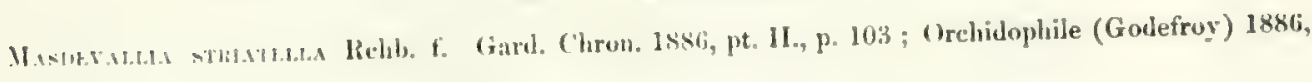
1. 346 .

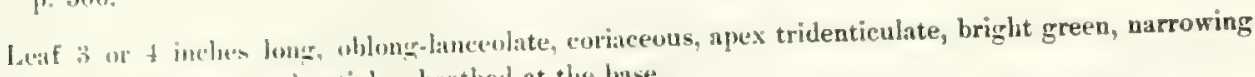

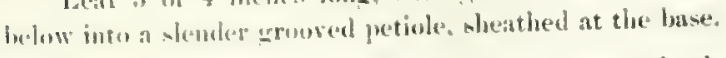

l'alunde abut 21 inches long. terete. very slender, ascending from the base of the petiole, pale Freen: hrant inch lon. unemhanous, appiculate. with a minute rudiuentary bud witbin at the base, pale Pellowish-irreen.

Wary in inch lome. with six eqrooves, bright green.

Siepals: dursit wipal united to the lateral sepals for nearly 3 incb, forming a wide tube, gibhous below, free purtion triangulatenvate for $b_{\text {is }}$ inch; fateral sepals cohering for nearly $\frac{1}{2}$ inch, free portions triangularwatte for $\$$ inch; ; all :-s-ueved, dull white, semi-transparent, with three bright crimson streaks, and all tapering into Hattened Heshy tails, if inch long, yellowish-olive, sometimes greenish.

l'etals f inch long.oblanceolate, with an angle on the anterior unargin, apiculate, rery pale pink, with a hroal central cimson streak, apex green.

Lij rather mure than t inch long. obloner, the basal half lobed, anterior half with two longitudinal kech. dull pink, with crimson qpots on each side, and three central crimson streaks, the base and apex rellowish.

Column nearly entulliug the petals, white marrined with crimson, apex with four crimson teeth.

THE first plant of .M. strintrll" known in cultivation was one imported in 1883 by

Mr. James OBritu, and given by him to Mr. Lee, of Downside, Leatherhead, in whose collection it flowered in 1886 , supplying the specimens first named and described by Profensor Reichenlach.

A latrer inportition of this species was afterwards made by Hessrs. Sander, from Tovar, in Venczucla, but no detaik of the exact elevation and temperature are forthcoming.

The following information has been received from Mr. Lehmann:

Mnsternllin striatella is comtined to the central mountains of Antioquia and tue northern districts of the. Canca, where it in distriluted over a large area, and extends vertically from 2,000 to 2,500 mètres (ti.j) to h.1 25 feet) above the level of the sea. Tle principal localities of its habitat in the Cauca are : in the forent of Minhmish. (iuntica, E. Irravanal, and on the eastern slopes of the Alto de Tatamá. In Antiopria is is lionul in the wouds of the undulating mountains around Picora, Aguadas, Sonson and Menpotania: in tile motutains of El Retiro, and on the Alto de San Miguel between Santa Barbara and (aldan: in mans places un the lighlands of Santa Rosa de ()os, near San Pedro, on the banks of the Rio Chico, and between Santa Rosa and El Yarumal.

It is grencrally a conmon but very local species, groxing abundautly in small isolated woods, and then not th lie found for many miles. It grows in damp shady woods upon trees near the ground, but also upun Liana-like sirul, of Thibandia and other Ericacee, in an average temperature of $14^{\circ}$ to $16^{\circ} \mathrm{Centi}$. grate (57.2 to 60 . \& Fahrenteit). In the Cauea and in the southern parts of Antioquia M. striatella flowers in (Octoher and November, and in the north of Antioquia during May and June.

Fixplanation of Plate, drawn from a plant at Newbattle Abbey :

Fig. 1, petal, lip, and column ; - Ia, section of orary ;-2, petal, inner side ; -3 , lip ; -4 , column ;4it. apex of column ; all enlarged; -5 , apex and section of leaf, natural size. 



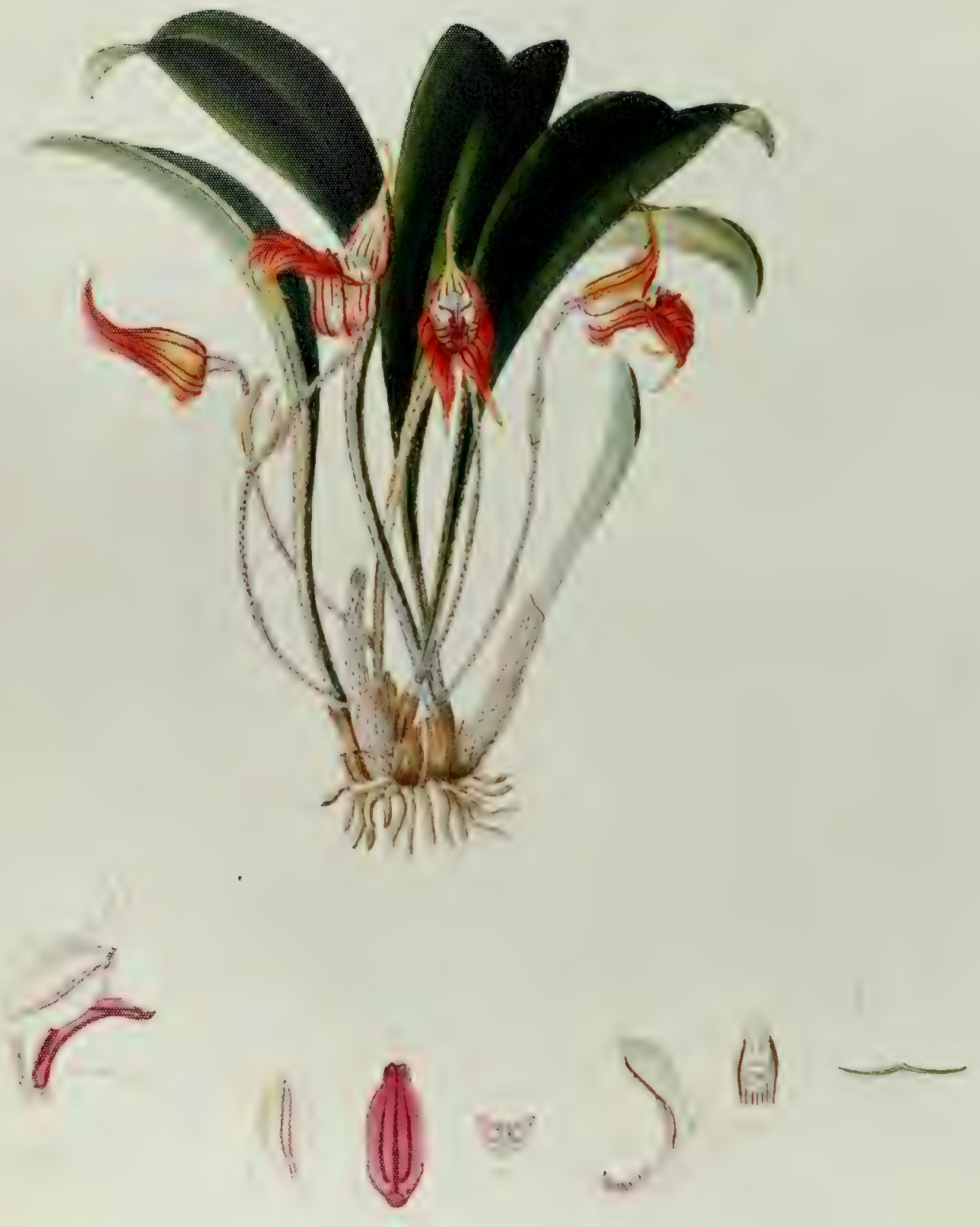


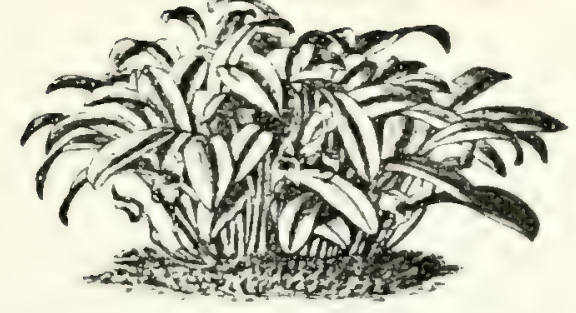

MASDEVALLIA TORTA Rehb. f.

Masneyalisa torta Rebb. f. Gard. Clron. 1883, pt. I, p. 110; Orchidophile (Godefroy), vol. I. $(18 \times 3)$, p. 795.

Leaf 6 or 8 inches long, oblong-orate, carinate, apex tridenticulate, much recurred, dark green, narrowing below into a slender grooved petiole, plale green spotted with crimson.

Peduncle, including pedicel, 3 or 4 inches long, slender, erect, with two or three sheathing bracts, rery pale green spotted witl crimson; flowering bract inch long, 3-nerved, sheathing below, ovate and apiculate above, pale greenislu-brown.

() wary allout 3 inch long, with six rounded angles, whitish spotted with crimson.

Sepals : dorsal sepal united to the lateral sepals for nearly $\frac{1}{2}$ inch, forming a wide gibbous tube, ovatetriancular for about 5 inch, 5-nerved, semi-transparent, pale greenish-yellow, with red spots and dark red nerves; lateral sepals coltering for 1 inch, oblong-orate, with 5 bifurcated nerves, bright red with dark red nerves, and spotted externally with red; all narroking into slender, flattened, yellow tails, that of the dorsal sepal $\frac{3}{4}$ inch, and those of the lateral sepais $\frac{1}{2}$ inch long.

Petals $\frac{1}{2}$ inch long, oblong-ovate, thick and fleshy, broadly angled within on the anterior margin, with riscid matter loelow the angle, apiculate, shining, pale yellow, with two crimson central lines.

Lilp s inch long, cleft at the base, with a minute rounded nectary on each side, tongue-shaped, closely covered with minute silver-white hairs, purple-crimson, with one central and two latenl dark purple nerves, alex covered with small papille.

Column $\frac{1}{2}$ inch long, pale green, edged and spotted on the foot with crimson, and haring four or fire crimson lines down the inner surface, gpex denticulate.

$T^{T E R Y}$ little information can be gathered concerning Mrastevallia tortu, even the name

of its discoverer being nnobtainable. It was first imported from Colombia for

Mr. Bull. and from his collection the specimens deseribed in 1883 by Professor Revicheninch in the Gardener' Chronicle were supplied. It appears still to be rather a scarre and little-known species, and even to be confused with $M$. leontoglosse, although at very sinht examination of the two species would immediately prove their distinctness

I an informed by Consul Lehmann that he las found flowers of M. tortu with longer tails that those in the accompanying plate, and that in these flowers the tails are sometimes twisted, in this respect resembling the specimens described by Professor Reichenbach, which suggested to him the name of "torta"

Consul Lehmam gives the habitat of this species in the following note:

Mreselecellin torte grows in dense and damp woods, upon trees which are thickly covered with mowe, near El Retiro, in the department of Antioquia, at an elevation of 2,300 to $2.40)$ metren $(7,150$ to 7.800 feet $)$ above the sea. It flowers in October and November. The ansual average temperature of this region is from $15^{\circ}$ to $16^{\circ}$ Centigrade $\left(59^{\circ}\right.$ to $(00 \times$ Filurenheit).

\section{F. C. LeHMANN.}

Lixplanation of l'late, drawn from a plant at Newbattle Abbey:

Fì.. 1. pretals, lipr, and columu, -in natural position;-1a, section of ovary ;-2, petal, inner side ;-3, lip:-3:a, bane of lij, showing nectaries (much enlarged); -4 , column; $-4 \mathrm{a}$, apex of column; all e'nlurgenl:- 



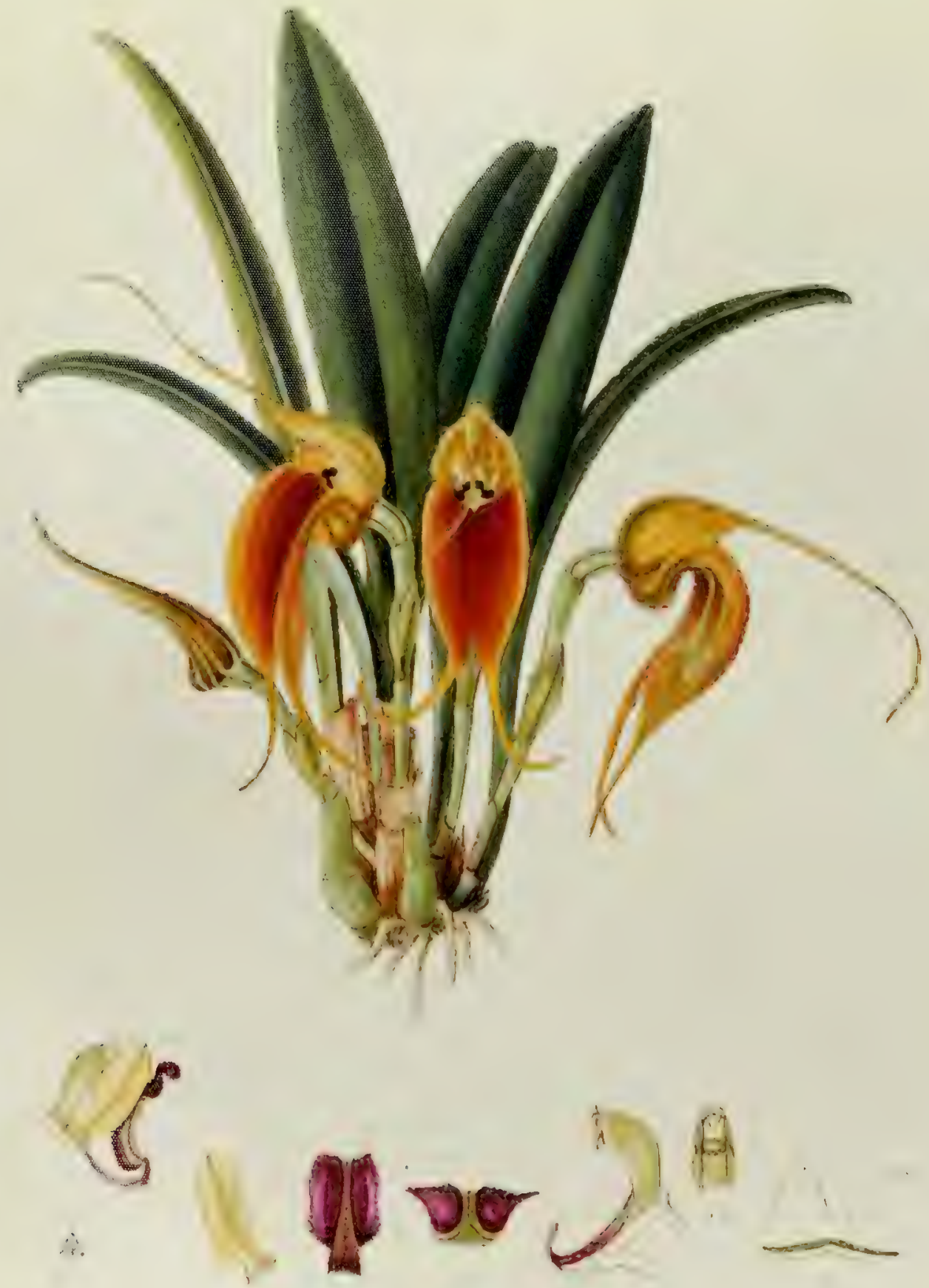


\section{MASTEVALLIA VELIFERA Rchb. f.}

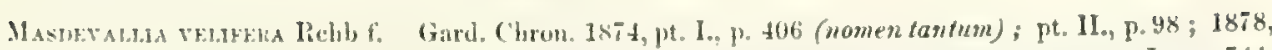

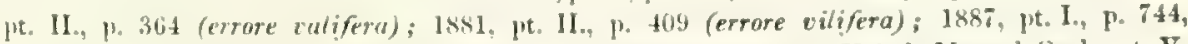

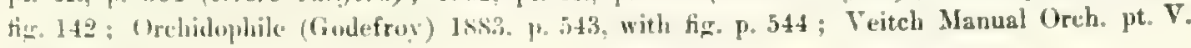
(1889), p. 699.

Leaf of or $x$ inclues long and alunt 1 incl, wide. oblung-lanceolate, very thick and rigid, apex obtusely tridenticulate, very dark trreen.

Peduncle about 3 inches long, terete, ascending from a joint at the hase of the petiole, with two or three sheathing bricts, bricht green ; flowering bract 1 inchlong, sheathing below, apiculate, 3-nerved, pale green or yellowisls, with a minute rudimentary lud within at the base.

()ary binch loner, curved. with three hoad and three narrow rounded angles, bright green.

Sipals: dorsal sepal united to the lateral sepals for nearly $\$$ inch, forming a wide gibbous tube, free portion 3 inch long. ovate, s̈-nerved, ochrevellow spotted with brown on the inner surface, tapering into a slender mil abont 21 inches long, orange. greenish at the back; lateral sepals cobering for about 2 inches. ohlong. ntitty reflexed, with is nerves, two of which bifurente, brownish-yellow, deepening to malosany brown in the contre. shining as if varnished, tapering into slender tails about $1 \frac{1}{4}$ inch long, orange, areenish at the back.

Petals about $\frac{1}{2}$ inch long, linear at the base, then oblong, angled on the anterior margin, apiculate, pule vellow tinged with green.

Liy inch long, broally oblong near the base, and united to the curved foot of the column by a rery flexible hinge, the apex and anterior margins much reflexed, dark purple, covered with small rough mpillat. the cential liue greenish.

Column about 3 inch long, curved, broadly winged, pale green, the foot spotted with crimson, apex crenate.

TIIIs handhone and curious species was discovered in 1874 by the Belgian collector,

Patin, who sent specimens to Mr. B. S. Willams withont recording its habitat. Tlue tirst plants which thowered in eultivation were imported for Mr. Bull by Shuttleworth, who found it in alumdance ncar Ocaña, in the Province of Santander, Colombia. The

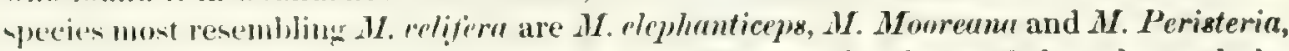
syceiall in the rigrid substantial texture of the flowers, the shape of the tube, and the momineice of the nerves upon the outer surface. None of these, however, show the peculiar shining brown colour of the lateml sepals so remarkable in $\boldsymbol{M}$. velifera.

The name rolifen signifies "sail-bearer," but Professor Reichenbach's reason for choosing it is scarcely apparent. The plant is still rare in cultivation, and $I$ am indebted to triends for specimens.

Fixplanation of Plate:

Fig. 1. petal, lip, and column, in natural position;-1a, nection of ovary ; -2 , petal, inner side ;3 , lip :-3a, lase of lip (ruch enlarged); -4 , column; -4 , apex of column; all enlarged; -5 , spex and scretion of leaf, matural size. 


V 


\section{MASDEVALLIA YAUAPERYENSIS Rodrig.}

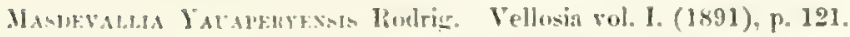

J.enf 4 inchess long. lincar-ublong, narrowing below into a olender grooved petiole, dull green.

l'ulumele includine the very short pedicel. albout 31 inches long, terete, very slender, ascending from the base of the petiolt. dark trreen: bract $f$ inch long, wate, apiculate, sheathing below, pale green.

Sophals volucring for a inch. forming $n$ camplanulate tube, free portions very short, triangular, pure white each with threo crimson streaks, greenish at the basc, tapering into flattened yellow tails 1 inch long.

L'etals ollenge-abal. surcled on the anterior unrgin. white, apes obtusely tridenticulate.

Lip a little longer than the petals. oblong, with two lateral lobes, grooved in the centre, white, spotted with erimsm eprecially at the base, apex recured, yellow.

Cinhum appalling the petals, whitc, varrowly winged with crimson.

$\prod^{I}$

IE rivel Yauapery, in Brazil, from which this little plant receives its name, is a tributary of the Rio Negro, rumning southward for nearly two hundred miles, and joining the Rio Nexro at abont $2^{\circ} \mathrm{s}$. lat. by $62^{\circ} \mathrm{W}$. long. The low banks, composed of allurium deposited by frequent floods, are covered with rank creeping vegetation, the loose soil bound together by the roots of coane grasses, and forming only at some distance from the river a sufficient foundation for the growth of shrubs and low trees, the outskirts of the dense forests which cover the surrounding country. Most of the trees are thickly entumed with mosses and flowering creepers, hiding trunks and branches, often killing the trees themselves, and forming immense masses of flowers and foliage espuinitely varied in form and colouring. In very damp shady places upon the

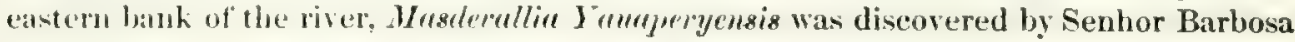
lodrigucz, growing anong the mosies a few inches from the ground upon the trunks of trees and especially upon the stems of lianas, or hanging in tufts by its clinging roots, and flowering from January to March.

Fenhor liodrignez, the first explorer of the river Yauapery, was commissioned in 1884 by the Governor of Amazonas to undertake the subjugation of a tribe of Indians named Krichanas, living upon the luans of the river and for many years the terror and scourge of peaceful act thers. During two vears he lived among them, frequently in danger of his life, persetriting almost to the source of the river and collecting valuable specimens along both bauks. By his courage and wise judgment be gained the confidence of the Indians, inducing them to give up their wild forest life, and leaving them comparatively civilised, and friendly tonatrh the agricultural and fishing population of the banks of the Rio Negro.

The temperature of the habitat of $\mu$. Imuperyensis is $26^{\circ}$ to $27^{\circ}$ Centigrade (about is to 4 Filnenheit), and the clevation is 60 mitres ( 195 feet) above the level of the sea. The dimeovery of this plant so far inland, amost in the heart of South America, in the fow allurial region of the led of the Amazon, throws a new light upon the geographical distribution of Masdevallias, hitherto considered to be a genus of mountain plants, chicfly restricted to a higl elevation and a cool temperature in the mountains of Central and somth Anerica.

for the accompanying drawing, as well as for the above information, I am indebted (1) Senbor Rodriguez, who, by his letters, and by forwarding to we a copy of his interesting work "Yeliosia, Contribuiçies do Museu Botanico do Amazonas," has done his utmost to reuder me assistance. His original description of the plant is as follows:

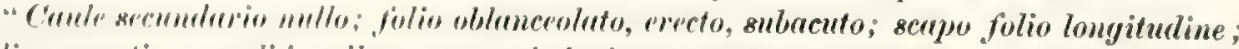

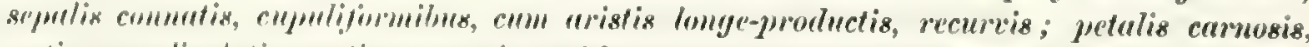

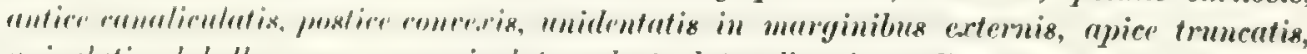

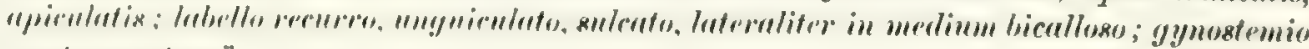

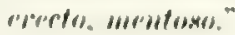

Explanation of Plate:

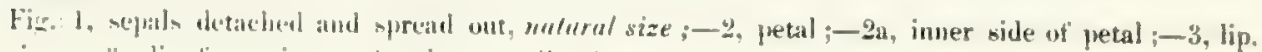

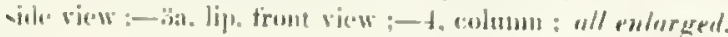





\section{CUCULLATAE Rehb. f.}

CWE plants of this section are distinguished by the extreme shortness of the pedicel, which camess the large cucullate bract to conceal the ovary and the base of the flower. All the known species are in cultivation.

$$
3 \text { species figured: }
$$

Madevalla corniculata lichls.

encullatat Lindl.

macrura Relslo if

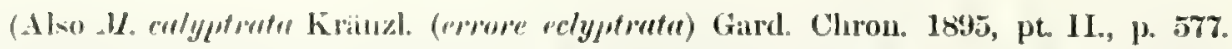
I Hew speries not figured in this work. Fl. Berlin 1895. Orange and brick-red. Hab. incogs.) 




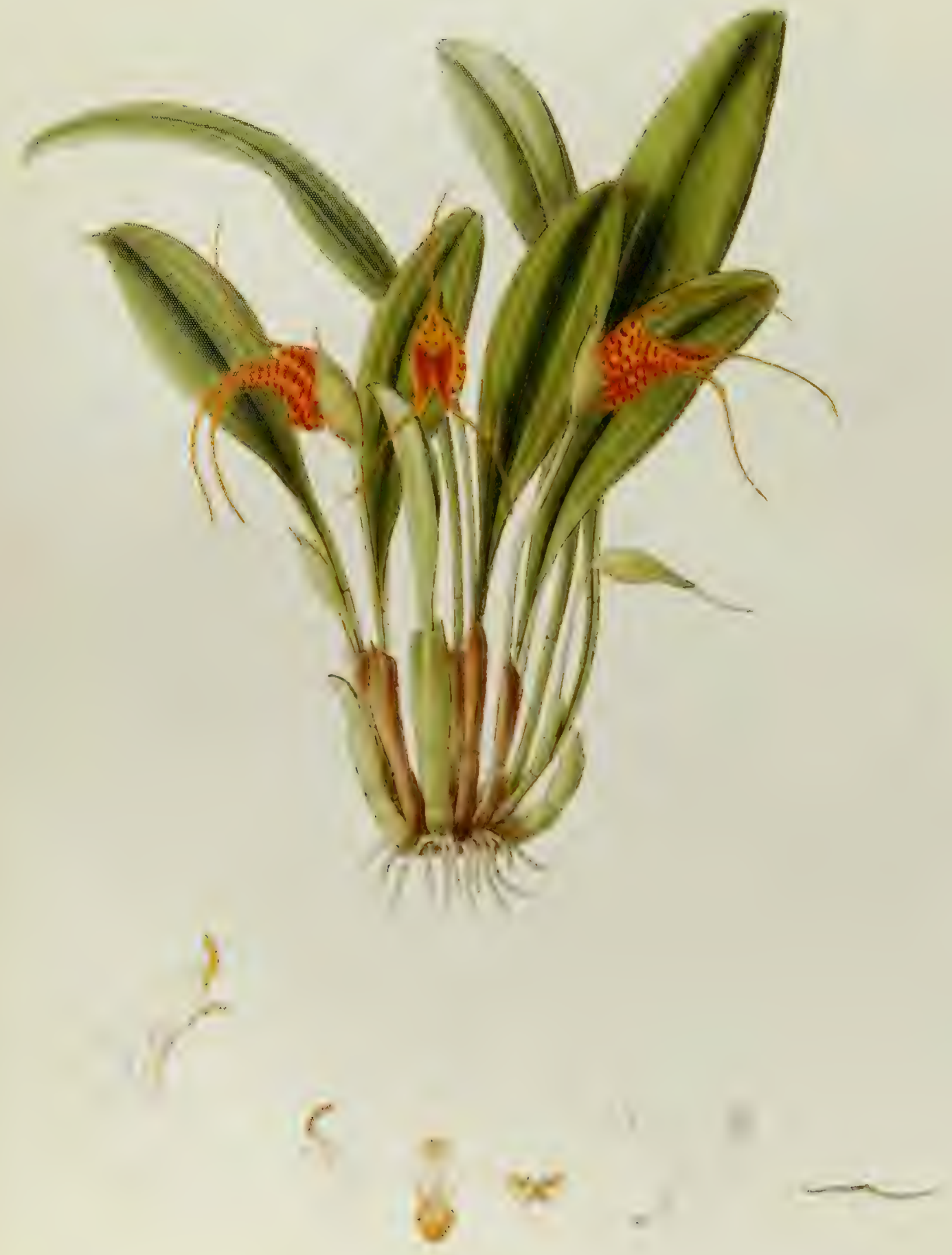




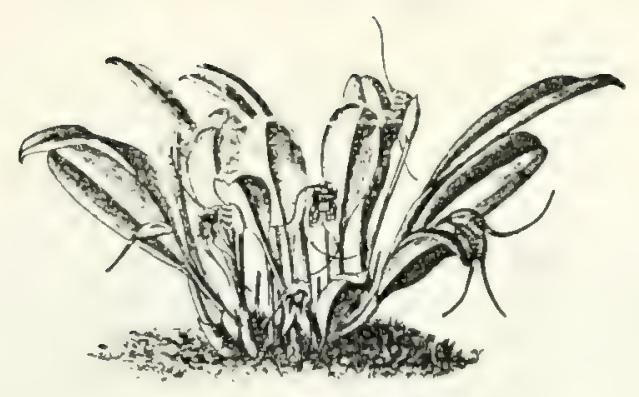

MASDEVALLIA CORNICULATA Rchb. f.

Masmivalia comiculata Rchb.f. Garl. Cliron. 1878, pt. I., p. 72 ; 1881, pt. II., p. 236; Veitch Mamul (Orch. pt. V. (18s9), p. 3i.

V'ur. imfafn, Veitch Manual Orch. pt. Y. (1889), P. $3 r ;=$ Masdevallia inflata Rebb. f. Gard. Chron. 1ss1. pt. II., 1. 716; Orehidophile (Godefroy) 1881, p. 172.

Lenf s or inche's long, about 1 inch wide, oblong-lanceolate, carinate, apex tridenticulate, margins reflexcel. bright green, narrowing below into a slender, grooved, pale green petiole.

Peluncle 3 or 4 inclies long, terete, ascending from a joint near the base of the petiole, pale green; hract very lare. concenling the orary and the base of the perianth, ovate, acuminate, pale green, with a redinentary buel within at the base.

Osary about $\frac{1}{4}$ incli long, triangular, with three crenate wings, bright green, sometimes spotted with r'rimson.

Sepals : dorsal sepal united to the lateral sepals for about 3 inch, forming a wide inflated tube, free portion trianenlar, very short, with three nerves, two of which hifurcate; lateral sepals cohering for about $1 \frac{1}{4}$ inch, oblongwate, with three carinate nerves, two of which bifurcate; all bright yellow, spotted with reduish-brown, and terminating in slender yellow tails, 2 or $2 \frac{1}{2}$ inches long.

Petals ahout $\frac{1}{4}$ inch long. linear-lanceolate, acutely angled on both margins, pale yellow, apex attenuate, prolonged, refiexed, orange-yellow, with numerous small papille.

Lip $\downarrow$ inch long, united to the curved foot of the column by a very flexible hinge, grooved at the base, with a concare nectary on each side, pandurate, with two short longitudinal wings, pale yellow, with small pink spots, apex rourd witls minute papillat, orange-yellow.

Colum nearly $\{$ inch Jong, winged, aprex slightly crenate, white, spotted on the foot with pink.

$\mathrm{M}$

ASDET. ILLIA CORNICULATA was discovered in 1877 by a collector sent out to Colombia ly ll essrs. Backhouse, of York, who supplied specimens from their plants for Professor Reichenbachis description in 1878. Consul Lehmann has not yet found this species in its native habitat, and the only information which he can give conreming it is that "it origrinates from the higher regions of the Andes, at an elevation of 2,500 to 8,000 metres " (8,12; to 9,760 feet). The specimen represented in the accomparying Plate affords an excellent example of the long, horn-shaped petals, which suggested the very appropriate name of "corniculate."

In the vear 1851 a variety of $M$. corniculutu, imported from Colombia, appeared in the collection of Mr. Bull, and was at first named by Professor Reichenbach as a distinct species. 21. influft. It has not been thought necessary to give a drawing of this variety,

Explination of Plate, dinsm from a l'lant at Newbattle Abbey:

Fin. 1, pretal, lip, and columu, in nutural position; - Ia, section of ovary ; -2 , petal, inner side ;-

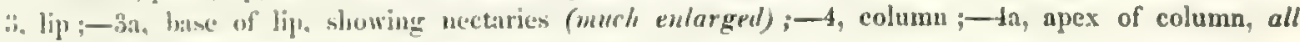
ruhriged ; - b., spes and section of leat, matural size. 

a rarer plant in cultivation than the type, from which it differs chietly in being of a paler, clearer shade of yellow, and scarcely spotted, the internal structure being identical. One. specimen, kindly sent to me by Mr. F. W. Moore, from the Royal Botanie Garden at Glasnevin, showed when fresh, very faintly coloured spots upon the outer surface, similar in size and colour to those of the usual well-known form.

The original collectors of these two interesting plants appear to have sent home uo field-notes as to locality or elevation, and it is to be regretted that no detailed information can be given. Consul Lehmann, however, suspects the existence of 1 . comicnlat" among the mountains of Antioquia, in a locality which he proposes to visit shortly, and it is hoped, therefore, that our present scanty knowledge may be added to at no vers remote date. 




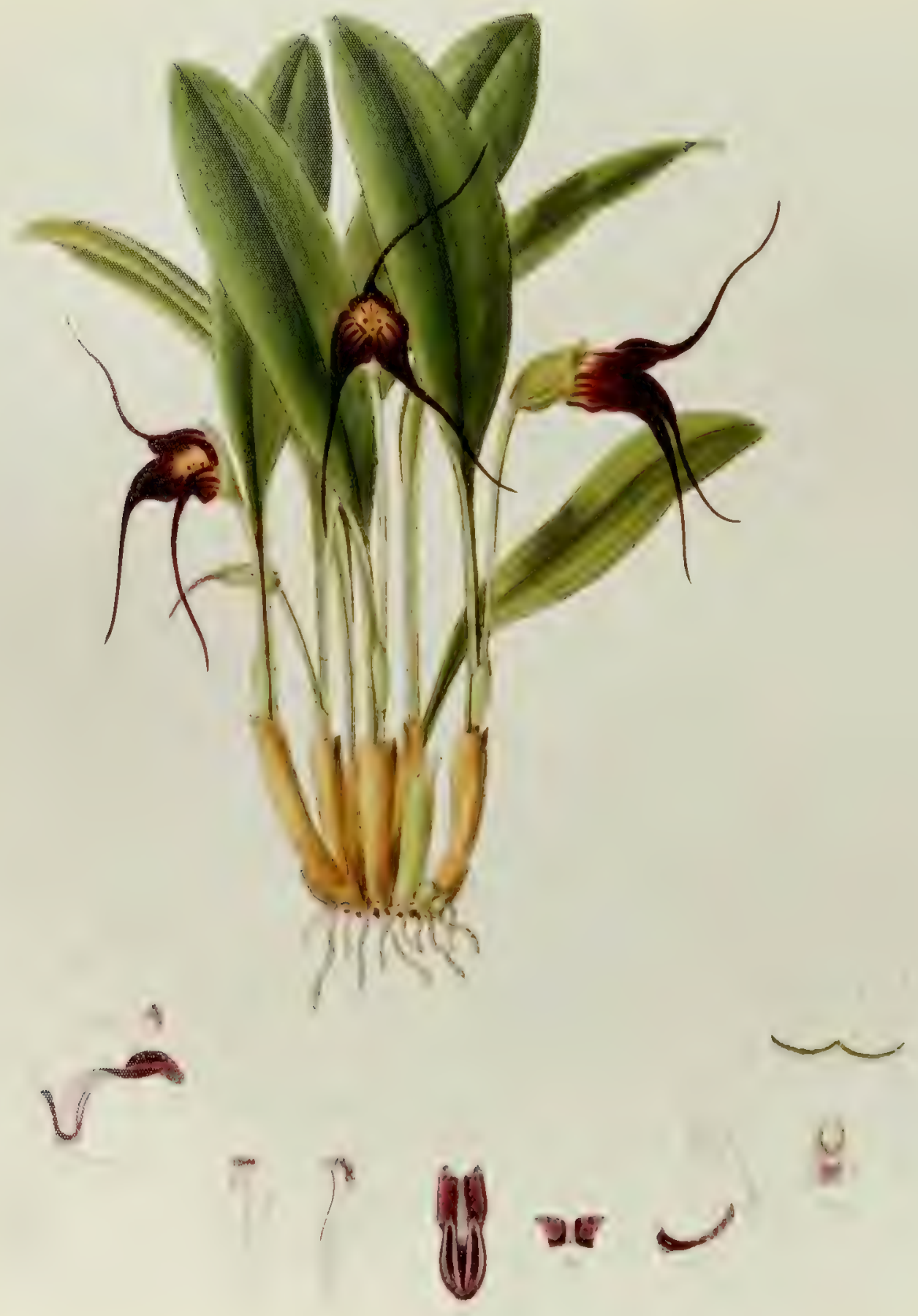




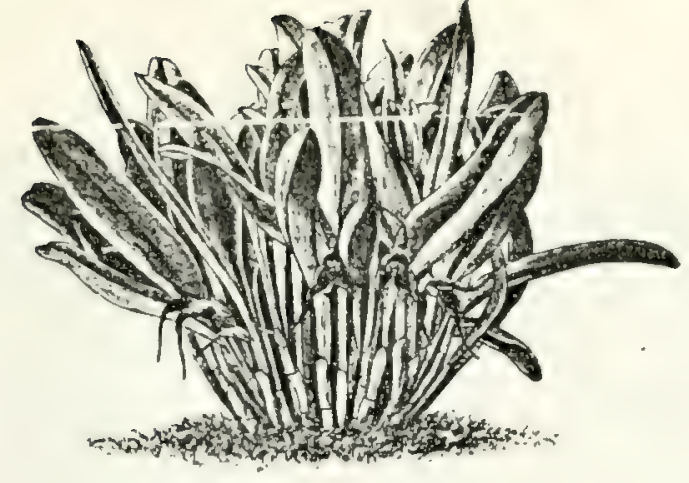

\section{MASDEVALITA CUCULLATA Lindl.}

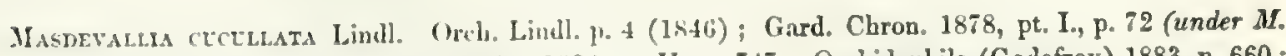
rorniculala) ; 18\$3, pt. 1., p. 392 ; 1\$st, pt. II., p. 74 ; Orchidophile (Godefroy) 1883, p. 660 ; Veiteh Manual Orch. pt. V. (1859), p. 38.

Leaf 9 or 10 inches long, ollongr-lanceolate, carinate, apex tridenticulate, margins often recurred, briglit areen, narrowing below into a slender groored petiole, pale green, sheathed at the base.

Peduncle $t$ or 5 inclies long, ascending from a joint about an inch above the base of the petiole, terete, slender, with two or three bracts, pale green; flowering bract about 1 inch long, entirely concealing the orary and the base of the jerianth, orate, acuminate, with a rudimentary bud within at the base, palc green, sumetimes spotted with crimson.

Ovary about 3 inch long, trianzular, with crenate wings and six deep grooves, very pale green.

Sopals: dorsal sepal united to the hiteral sepals for about $\$$ inch, forming a wide tube, gibbous benenth, yale green, and having within at the base a rounded shining excrescence, dask crimson, free portion 3 inch long, triangular, with three nerves, two of shich bifurcate near the base; lateral sepals cohering for $\frac{1}{2}$ incls, free portions $\frac{3}{4}$ inch long, uvate-triangular, with three nerres, two of which bifurcate near the basc. all claret-crimson, and tapering into very slender tails $1 \frac{1}{2}$ or 2 incbes long, dark crimson, stecnisli at the back.

I'etals abut $\neq$ inch lome. linearrol, lonw, mugled on hoth margins, white, apex obtuse, reflexed, angled, and covereal on the inner surfice with crimson pay pillas.

Lip I inch lomg, oblong, grouved down the centre, with a small nectary on each side at the base, and two loneritudinal keels on the anterior fortion, crimson, paler in the centre, apex reflexed, dark crimson. pmiple, corered with small papillat.

Colum $f$ inch lone, uarrowly winged, apex entire, white, the foot and inner surface bright crimson.

THIS suecien was first described in 1406 by Dr. Lindley, who quotes the field-note of

Jons. Linden, its discoverer, as follows: "An epiphyte from the thich forests of Fusacasuga, in the province of Bograt, at the height of 7,300 feet."

Ilthomgh discovered as long aro as $1 \mathrm{H2}$, M. cucullata was not known in cultivation until 1sis;, when living phuts were brought home by Mr. Carder, and first flowered in the collection of Mr. Shutheworth. It has an extensive geographical distribution, laving been found by munemo collecotor in different Departments of the Republic of Colombia. Consul Leluman, in the following note, gives several localities in which he loas limself found the phat:

Explatuation of Plate, drawn fiosn a Plant at Newbattle - Lbbey:

Fig. 1, petal, lip, and column, in nutural position;-1a, section of ovary ; -2 , petal, inner side ; -

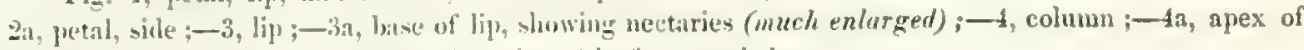
column; "ull enlurged; 5. slyex and section of leat, nuturnl size. 

Masdevallia cucullate comes from Colombia, where it is rery irregularly dintributed over a large area. I have observed it in the following localities:-in the Eastern Audes of Bogotá, on the westeru slopes of the Alto de las Oséras in the Department of Tolima, and from here northwards on the western declivities of the Parmmos de Sumapaz, Andabobo, Santa-Rosa and Sibaté in the Department of Cundinamarea. On the highlands of Antioquia, near the town of El Retiro and on the Alto de San Higuel. In the Western Andes of Popayan, upon the eastem slopes of the Cerro II unchique. In the Eastern Andes of Pasto, on the descent from the Pirmo del Bordoncillo into the valley of Sebondoy, and also in the vicinity of the village of Putumayu, I observed, in the year 1850, a Marderallia which, although not in flower. appeared to be identical in all its characteristics with $\boldsymbol{M}$. cucullata. The plants were extremely well developed.

Masdevallia cucullata grows in dense and very damp woods, on the truntis of trees near the ground, and also upon the ground itself where deep layers of decayed leaves have accumulated. The elevation of the localities in which it occurs varies from 2,000 to 2,600 mètres $(6,500$ to 8,450 feet $)$, with a temperature of $13^{\circ}$ to $16^{\circ}$.5 Centigrade (about $55^{\circ}$ to $62^{\circ}$ Fahrenheit). The climate is remarkable for heary and constant rain. and an atmosphere highly charged with moisture throughout the year. A really dry season, during which all rain ceases, never occurs in those regions. In most localities M. cucullata flowers during the months of October and November, but in the Boyrota districts the flowers develope in January and February. Although seed-eapsules are very commonly met with, $M$. cucullute is not an abundant species.

F. C. LEmMNX. 




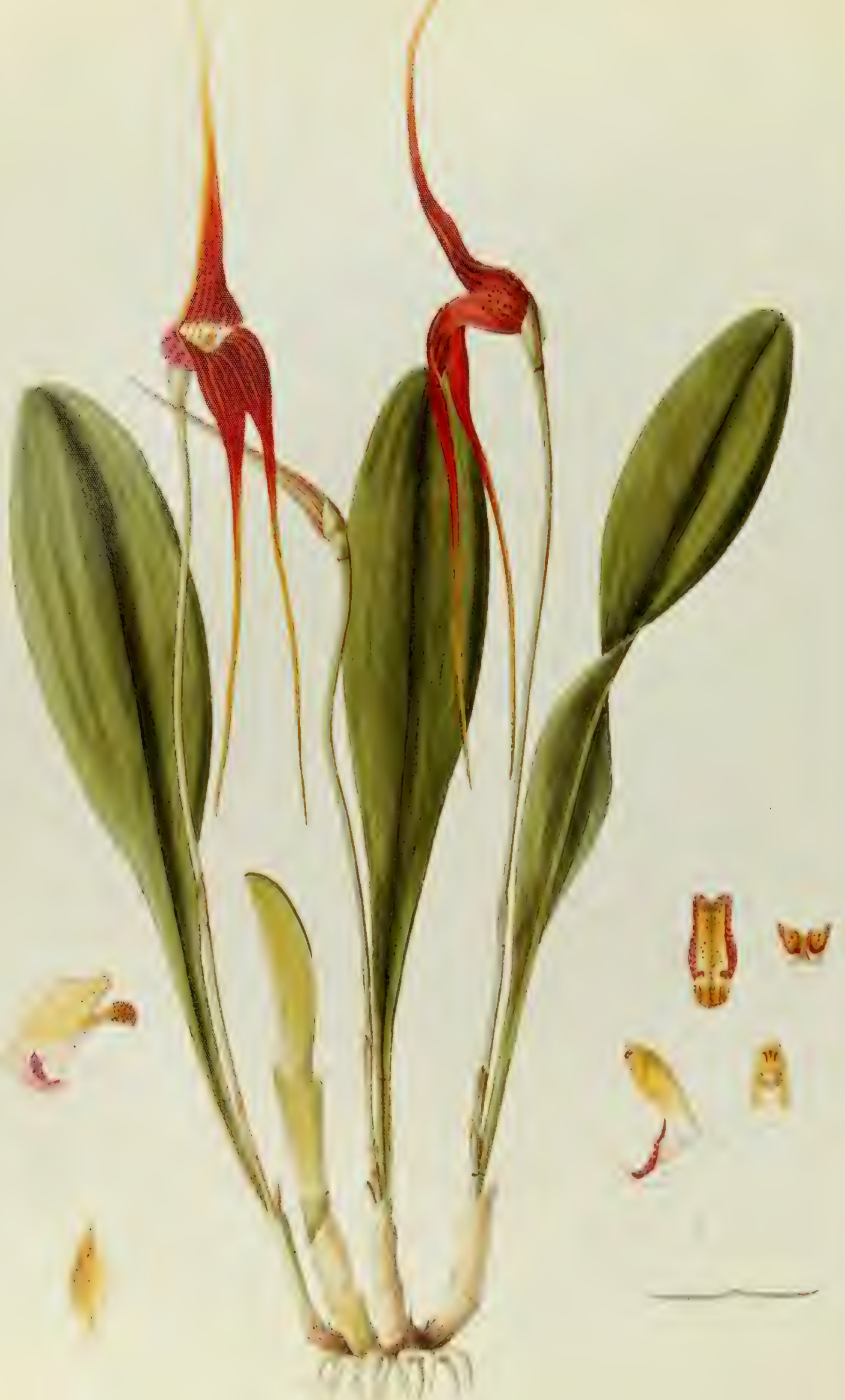




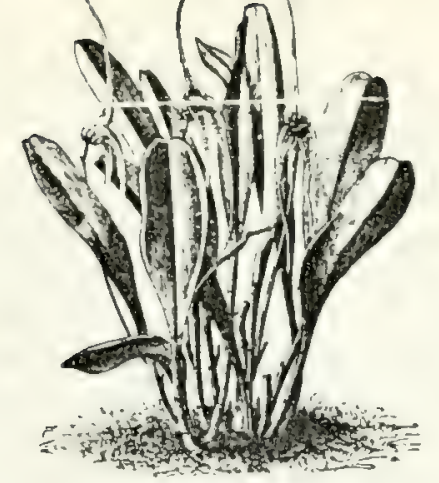

MASDEVALLIA MACRURA Rehb. f.

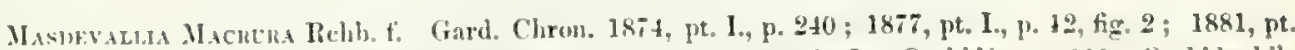
II., 1. 136, tig. 65 ; Limnar, XLI. (1875). 1. 11 ; De Puydt, Les Orchidées, p. 100 ; Orchidophile (Godefroy), 1sis3, 1) (it2; Lindenia, vol. III. (1887), t. 113.

L.anf 10 or 12 inches long, 2 or 2 ! inches wide, oblong, carinate, ohtusely tridenticulate, erect, bright ureen, uarrowing helow into a slender petiole, decply grooved, pale green, with large membranous sheaths at the bave.

l'eduncle! or 10 inclues long, terete, ascending from a joint at the base of the petiole, with one or two hicathime bracts. jale green; fowering hract 3 inch long, 5-nerved, apiculate, sheathing below, entirely covering the ovary, often with a small hud within at the base, pale green.

Owary ahut 3 imch long, terete, with six indistinct grooves, pale green, sometimes spotted with hrown.

Sepals: dursal repal united to the lateral sepals for about $\frac{1}{2}$ inch, forming a wide tube, oblong-ovate. F-nerved, whitish at the batse, then orange-sellow, shaded and spotted with reddish-crimson; lateral sepals cohering for nearly 1 inch, olylon-ovate, with four strongly carinate nerves, three of which bifucate. dotted with hlackialu-crimon papillat, orange-yellow deeply shaded with crimson, all tapering into slender Hattened vellow tails about 4 incloes long.

l'etal- alsout 3 s ind long, whlong, curved, fleshy, anterior margin much thickened, posterior margin acutely anglud. alyex very olutuse. bright yellow with brown spots.

Lip I inel, bong, whong, Hesly, with two dee nectaries nenr the base, and two longitudinal keels, rellow youted with dark crimon. apex retlexed, much thickened, orangrevellow with a few dark spots, rough with papillate sranged in three obsenre lines.

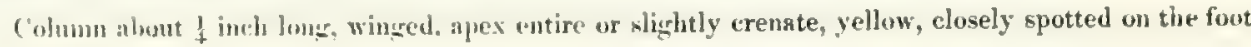
witl crimsun.

M

ASIOENAILIA MAC'RT RA was discovered in 1871 by Roezl, near Sonson, in the province of Antiopuia, and was described in 1874 by Professor Reichenbach from dried specincess. The first lising plants were imported in 1876 by Mr. Shuttleworth, and first Howered in the collection of Mr. Bull in 1877. In the Gardeners Chronicle, 1877. 14. 1.. 1. 12, Profimol Rejehenbach states that a short-tailed variety was collected ly Patin, a Belgian traveller: and a girsutic variety is mentioned by Roezl in the following account of the town of tionson. taken from Godefroy's "Orchidophile," 1823, 1) fit?, from which we leam that fiomson is a little town of $4-5,000$ inhabitants, situated in the State of Antiopuin, on a small tributary of the Rio Cauca, on the boundary, and a little to the north of, the state of the same name. This town deserves to be called the city of Jisclevillis, for Rocal fouml there, on the roof of one house, as many as four

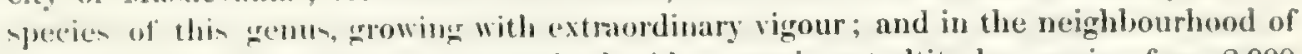
the tom nore than twenty-five species besides, growing at altitudes varying from 2,000 to $-5,50$ metres $(6,500$ to 8,125 feet $)$. Roezl adds that the local name for $M$. momern is 

"La Viuda,"-"The Widow"; but, aceordinge to Wallis, this name is given to H. rnenlloflo. a much darker flower. In 1871, M. mecruma was so albundant in this locality, and the native children collected it for Roezl in such quantities, that he was obliged fo abburbon more than a thousand plants. The plant grows most commonly upon great blectis of granite, seattered over the ground, and thickly covered with mom. Rain in very frefluent, and almost every morning the for is intensely thich, with a temperature, aceording tor Roezl's account, of five or six degrees below zero Centighde, or ninc to clevest dengers of frost Fahrenheit. Consul Lehmann, however, informs me that this statcurent is erroneous, and that the lowest temperature registered in the neinhbourhood of sonson is only $31^{\circ}$ or $30^{\circ}$ Fahrenheit, or one or two degrees of frost.

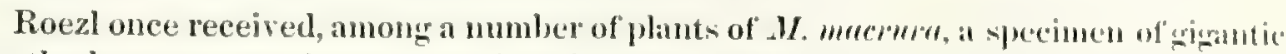
size, the leares measuring two feet long by four inches wide, and rery thich. The onh flower upon the plant was also of unusual dimensions, measuring nearly twelve inclien across. It must be presumed that this measurement was fom tip to tip of the extended tails. Owing to the faded condition of this flower, Roezl could not decide whether it was a distinct species or only a variety of $M$. mecrum, which it appeared to rememble exactly in shape and colour. Even by offering a lange reward to the young inhathitut of Sonson, he never succeded in obtaining another specimen of it.

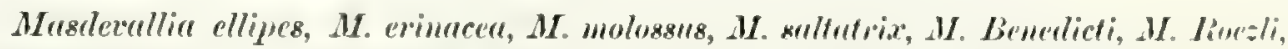
and other species, were found by Roezl growing in the neighlourhood of somson undes exactly the same conditions as $\boldsymbol{M}$. mecrura.

Consul Lchmann adds the following information :

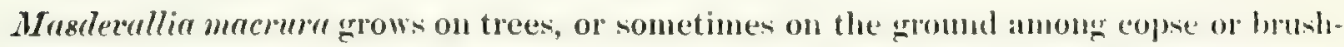
wood, in dense and damp woods, on the Alto de sin Miguel and above Envigado, in the department of Antioquia, at an elevation of 2.300 to 2,600 metren ( 7,475 to -4.4 .0 feet $)$. It has been also observed near Sonson and other parts of Antioquia. This species flowers in October and November in its natumal habitat.

The anuual average temperature of the regrion ranges between 14 and 15 decreen Centigrade (57 and 59 Fahrenheit). There are two rang and two dry seanoms during the yeall : the first miny season lasting from the end of March until the end of ounc; the second from the end of September until December. The hygrometric arerage in letween $69^{\circ}$ and $70^{\circ}$ per cent. during the dry months, and $76^{\circ}-78^{\circ}$ per cent. during the wet ones.

\section{F. C. LFuмx:}

Explanation of I'late, drawn from a plant at Newhattle Abbey :

Fig. 1, lip. petal, and colum, in natural position;-1a, section of ovary ;-2, petal, inner side :-

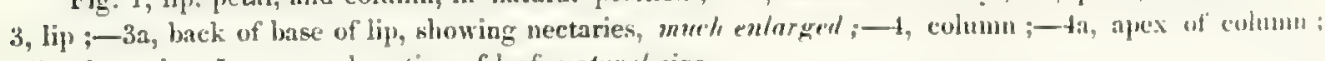
all enlarged; -5 , apex and section of leaf, malurul size. 



\section{FISSA Rehb. f.}

O.XY me yeries of thin section is in cultivation, and I can ascertain the mames of lint twe others. (omnl Lelmman has, in his Herbarium, a few specimens of allied phants-mumbed. The domal sepal is not united to the lateral sepals, and this perenliarity sugerened Reichenbachis name for the inroup, Fisene, or eleft.

1 - ipecies tigured :

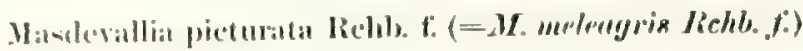

Not in renlfiention:

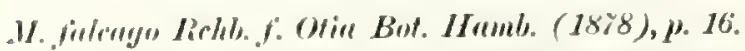

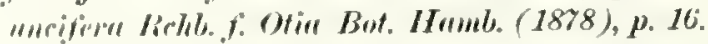






$$
2179
$$




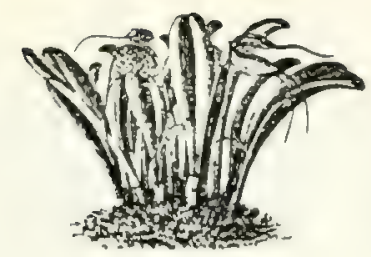

\section{MASDEVALLLA PICTURATA Rehb. f.}

Masmeralia meturata Rchb.f. Xen. Orch. I. 11858), p. 198, pl. 75, fig. 1 (as M. meleagris); Otia livt. Hamb. 1. 16 (1878); Orchidophile (Godefroy), vol. I. (1881), P. 193; Gard. Chron. 1882, pt. I., p. 10: Truns. Linn. Soc., vol. II., pt. 13, p. es1, Bot. Roraima Exped. 1884, E. F. im. Thura.

M. melengrsis Reht. f. Xen. ()rch. I. (185S), p. 198, pl. 75, fig. 1=M. picturata Rehb. f., Otia Bot. Hamb. p. 16 (1sis), non. .M. meleagris Lindl. Ann. nat. hist. vol. XV. (1845), p. 257.

Leat at inches long, obloug-lanceolate, obtusely tridenticulate, Heshy, narrowing below into a slevder grooved petiole wheathed at the base, dull green, the older leaves spotted with dull brown.

Peduncle abont 21 inclues long, slender, terete, erect, with one or two sheathing bracts, pale green; flowering brat 3 inch long, apiculate, orate, almost concealing the orary, pale yellowish.green.

Wvary \& incly long, with six strongly crenate wings, bright green.

Sejals: dorsal sepal entirely free from the lateral sepals, nearly $\frac{1}{2}$ inch long, oral-oblong, 3-nerred, very fille veliow, with numcrous velvety crimson spots, terminating in a slender bristle-like tail 14 inch lons. hruwish-crimson; lateral sepals cohering only near the base, about \& inch long, oblong-ovate, 3-nerved. nerves carinate without, pale yellow, bright orange at the base, spotted with velvety crimson, termimating in slender bristle-like tails 1 inch long, brownish-crimson.

Petals $\neq$ inch long, ligulate, witls a fleshy process within the anterior margin near the base, apex acutely tridenticulate, the central tooth prolonged, pale yellow.

Lip ahout 3 inch long, united by a hinge to the foot of the column, grooved at the base, with two lateral lobes. apex with three rounded lines, orange-yellow, spotted with reddish-brown.

Column nearly $\frac{1}{4}$ inch long, slender at the base, winged, apex green and crimson.

M

INIEVILLIA PICTCRATA was discovered in July 1850, by Wagener, near Carueas in Tenczuela, at an elevation of 6,000 feet, and was also found at Tovar in 18.5 by Fendler. Profenvor Reichenbach appeas at one time to have considered this specice to be identical with $\boldsymbol{M}$. melengris Lindl., for he published in $18 \mathrm{~s}$ a drawing of W. pirtmote under that name (Xew. Orch. 1. p. 198, pl. 75, fig. 1). Later, however, be explaim that he had never seen Lindley's $M$. melengris, and that the plant represented in his Plate was . p. picturatr, not the true 1 . melengris of Lindley (Otia Bot. Hamb. 1678, p. 16). The latter plant-of which the original specimen, discovered in $1815 \mathrm{by}$ Hartwer between the Pámono de San Fortumato and Fusagasuga, Bogota, is preserved in the Roval Herbariun, Kew-is most distinct from $\boldsymbol{M}$. picturata, the leaves being nore rounded, on a slender petiole, and the flower-stem nearly five inches in height. The flower is differently shaped, and the dorsal sepal is marked with narrow and regular bands of purple. The strongest point of difference is perhaps the slender wingless ovary, the ovary of $M$. picturut having, as will be seen in the accompanying Plate, fig. 1u, six remarkibly waved or crenate wings, a characteristic not present in so great a degree in any other species yet known.

14. picturutu is especially interesting in having a very remarkable geographical distribution. of which the extreme limits, as at present known, are: On the south-east

Explanation of l'late, drawn frum a l'ant at Newbattle Abbey:

Fig. 1. petal, lip, and column, in natural position ; - la, section of ovary; -2, petal, inner side ;-3,

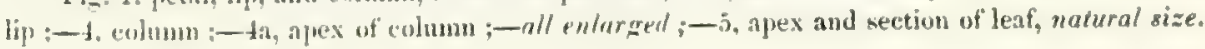


Hount Romima, on the boundary between British Guiana and Venezucla: on the north the mountains of Caracas: on the south and west ('ali and Tolinis in the Wentern anel Central Cordilleras of Colombia, and Frontino in Antioquia; and on the north-west Costa Rica.

Specimens from these localities vary greatly in size and depth of colour. Thone collected upon the upper slopes of Hount Romima at an elevation of alowt fi, (xon) feet, during the "Romima Expedition" of 18515, flowering in Fovenber and Decenber, are" less than two inches in height, the colour, ats far as can be judged from dried flowers. being much the same as in the plant here figured, while the apex of the leares is more sharply denticulate, with the central tooth longer than the lateral ones. some of thene dried specimens were sent in 1855 by Mr. Everard im Thum to the British Musemu of Natural History, where Mr. H. N. Ridley, then a member of the Botanical Stafl, identificel them with $M$. picturata Rehb. $\mathrm{f}$.

On the western slopes of the Westem Cordillems of Colombia exactly similar plants have been found by Consul Lehmann, growing on trees in thick damp forests at an elevation of 5,850 feet, and flowering in A pril. Larger specimens were also collected bs him near Tolima, at an elevation of 6,500 feet, growing on trees and often on dead wood in the damp forests of the upper Rio Cabrera, flowering in January, These plant although the flowers are of darker colouring-the brown spots being almost suffused orer the surface of the sepals-approach most nearly the variety here represented, a plat found near Caracas by Mr. Edward Wallace, of Colchester, in 185, at an elevation of about 6,000 feet, growing on the stems and lower branches of trees.

Plants from Frontino in Antioquia, also found growing upon forest trees (elevation 2,500 feet), are intermediate between those from Mount Roraima and Cali, and those from Tolima and Caracas, closely resembling plants found in Costa Rica by Shuttleworth in 1883. The largest form seems to be the specimen found by Fendler in Fenezucla in 1854, now preserved in the Kew Herbarium.

A nearly allied species, at present un-named, has been found hy Consul Lelmann in the mountains of Cauca, growing on trees in rather thich forests above Chapa on the Tambo at an elevation of 6,500 feet. The plant is only alout one inch in height, and hits white flowers with yellow spots and an orange lip. A single dried specimen of this little plant is preserved in the Boissier Herbarium at Chambés, Geneva.

There is but little variation in the temperature of the different localities in which M. picturata is found, the annual average being from $59^{\circ}$ to about $67^{\circ}$ Fahrenheit.

Owing to the delicacy of the species, many attempts to import it alive have totally failed. Of four thousand plants collected in 1855 by Mr. Edward Wallace, with which he started on his homeward voyage, ouly forty reached Europe alive. Mesirs. Sander of St. Albans have also succeeded in importing living plants, and the first flowers seen in England were those in their collection described by Professor Reichenbach in 1ss?, in the Gardeners' Chronicle, pt. I. p. 10. 



\section{SECTION VI.}

\section{MINU'IA Rehb.f.}

A SOMEWHAT mincellaneous Section, comtaining small species which cannot correctly be climed in any other group.

4 species figured:

Mavelevallia attenuata Rehb. f. niditien Rehb. f. ophioglossa Rchls. fo (not in cultivation.) Wendlandiana Rehb. f.

Not in renltiention:

H. (Muntulenaix Liehb. f. Otin Bot. Hamb. (18;8), p. 17.

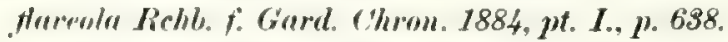
hious Limel ot Rehb. f. Bunplomelia II. (1854), p. 284. Lunsbergii lichb. f. Neder Kruidh. A rch. IV. (1859), p. 317. mimuta Rehb. f. Limll. Ann. Nat. Hist. XII. (1843), p. 396. ophioglosisa Rchb. f. (see Plate.) pumila Poepp. et Endl. Nor. Gen. et Sp. II. (1888), p. 6, t, 108. puriolle Rehb. fo Gurd. Ghron. 1887, pt. 1., p. 140. 





\section{MASIOEVALLIA ATTENUATA Rehb.f.}

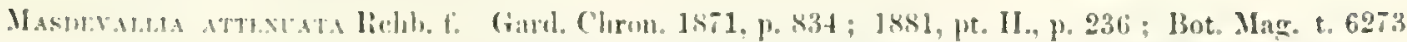

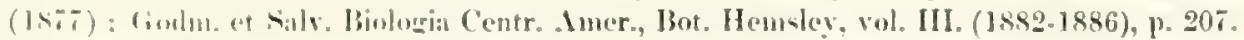

Locat : inchen long. line:ur-lanceolate. coriaceous, apex tridenticulate, narrowing below into a slender

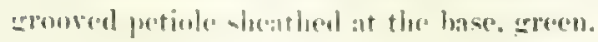

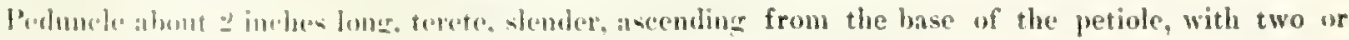

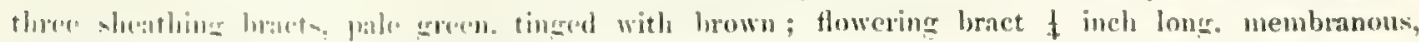

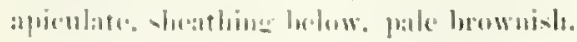

Wary, inclu leng, with six rombled angles, paic green.

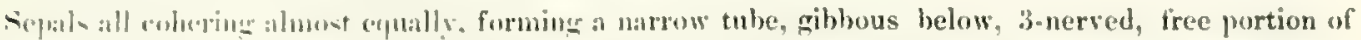

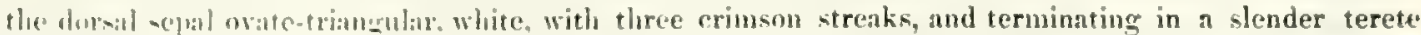
tail meirly ! inelh long: free portion of lateral sepals oldong-ovate, white, with two crimson streaks, and cerminatine in slonder perepe tails ? inch long: lase of the tube vellow, tails orange, greenish at the birk.

l'etals a litfle: more tlan! imol, long, whomg-lanceolite, with a wide angle on the anterior margin and :11 allshed keel. white.

Laij a little longere than the petals, base thickened and united by a hinge to the foot of the column, chlone-cordate, with two longitudinal angled kecls, marrins crenate, white tinged with pale vellow, apex a minute or:mere cushion, with crimson dots.

Colum shorter than the petals, winged, white and pale pink, brondly edged with crimson, apex denticulate.

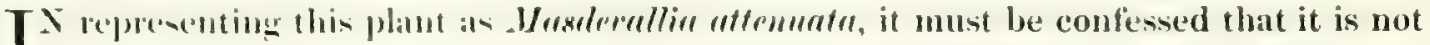
(xalctly the sime at that figmed in the Botanical Magazine (t. 6273) under that namse. and in order to show the differences besween the two, I have reproduced a porrom of that Plate at figs find 7 . The flower here shows no crimson streaks, and the -hape of the petal (fig. o) is different, heking the marginal keel and angle (fig. 2) rematable in all the specomens which I lave c'smoned. The lip in both flowers is much the sime in structure, and the two plants ean, perhaps, hardly be specifically -rpanated. The form represented in the Botanical Marazine appears to be very rare in cultivation, even if it now exists at all, for, in all the collections of Masdevallias-in thin country and on the continent-whose owners have generously placed specimens at my alispmil. the plant which I figure is grown as U. atfenuta. Sowhere have I been

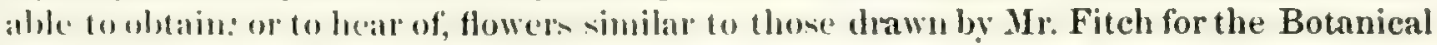
Magizine, in 1siz, which are. no doubt, the orjginal form of the species named and

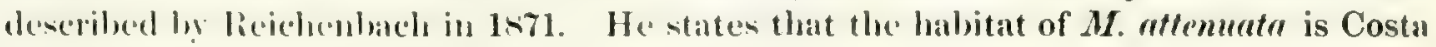
lieas. Whence it was imported by Messm. Veitch.

Explanation of l'late:

lïg. 1. pretal, lip, and colmun, in uatural position; - Ln, section of wrary ; -2, petal, inner side :-

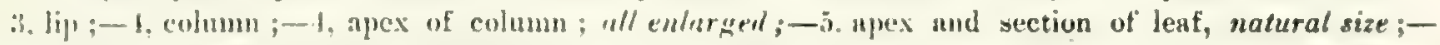

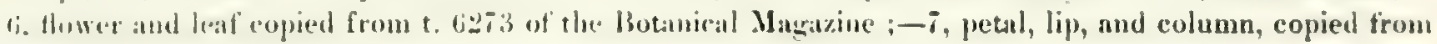
hig. 2 of the sime Plate. 




$$
3 \times 15^{\circ}
$$




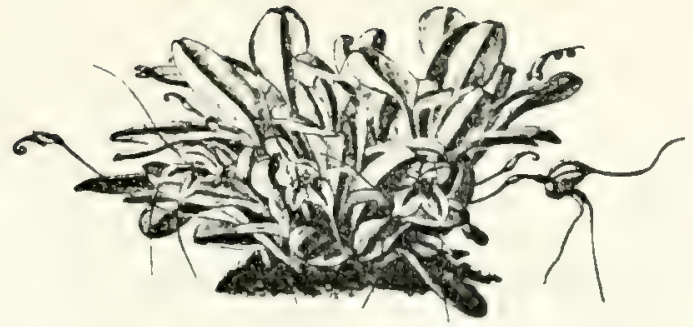

\section{MISIEVALIAA NIDIFICA Rchb. f.}

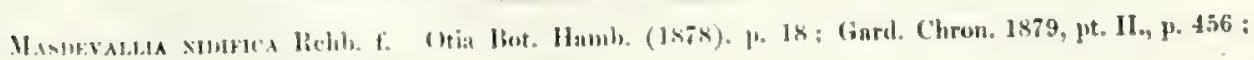

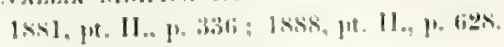

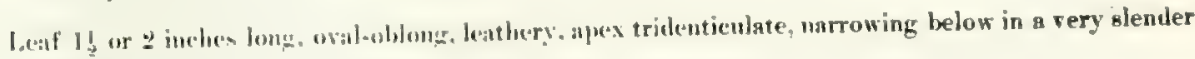
innowed petiole, shenthed at the base.

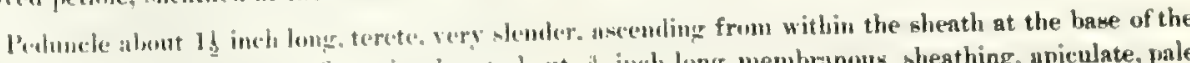

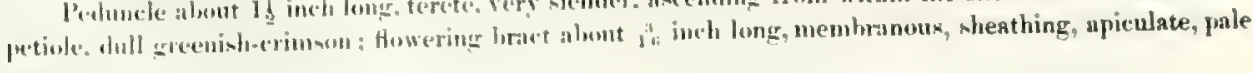
Itrexe+1.

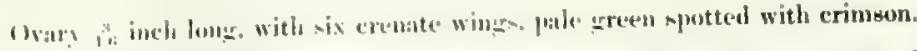

Sepals: dowal sepal united to the latcrit sepals for it inch, forming a roundly infated tube, gibbous

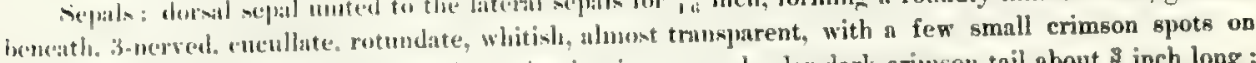

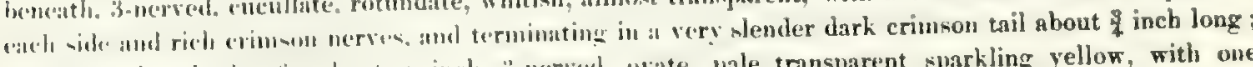

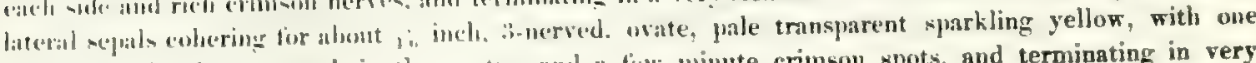
broal reddinh-crimson stresh in the contre, nul a fiw minute crimson spots, and terminating in very

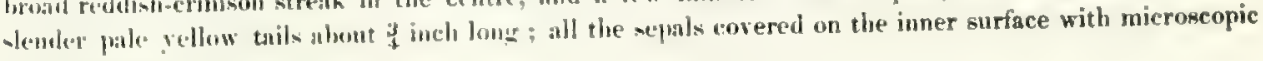
velvety hairs.

l'etals $\frac{1}{1}$ inch long. linen-oblong, with a atroug keel on the anterior margin, whitish, nearly tran-fisent, strabed with crimson.

Lip a little longer than the petals. pandurate, curved, united to the eurved foot of the column by a Hexilble hinge, vellow, with three eentral crimson streaks.

Colum a littlo longer than the petals, narowly winged. whitish or pale pink, marked and edged with crimsoll. stpex entire.

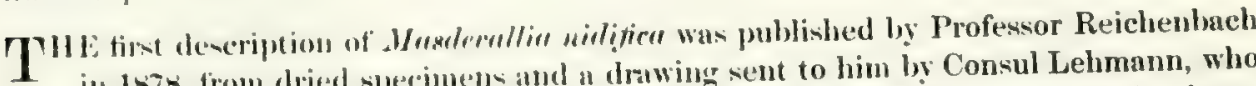

in 187R. from dried specinnem and a drawing sent to him by Consul Lehmann, who

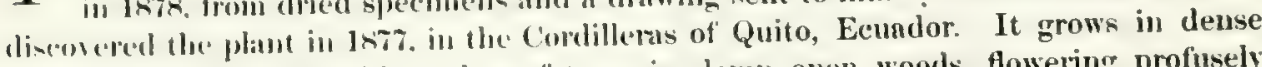
mamen on the trunks and branches of trees in damp open woods, flowering profisely during the heaviont rans of Fehruary. throughout March and April, and again, even more alumdantly, in september, the driest month of the year.

Thare alpear to be many varieties of $M$. milifien, which differ chiefly in size, some leving erens smaller than the phant here represented, and others attaining a height of three inches.

The best anthority upon the labitat of this species is Consul Lehmann, its diseoverer, who sils:

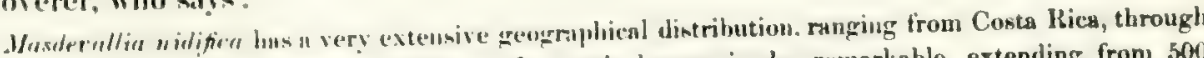
('olmuhia and Fcuador, to the nurth of l'eru. Its vertical moge is also remarkable, extending from 500

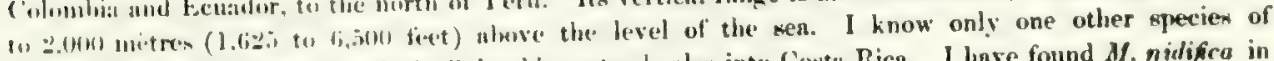

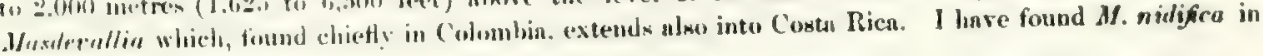
the following localition:

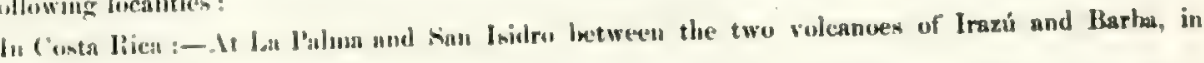
Inсcеminer $1 \times 81$.

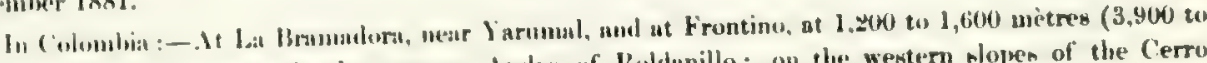

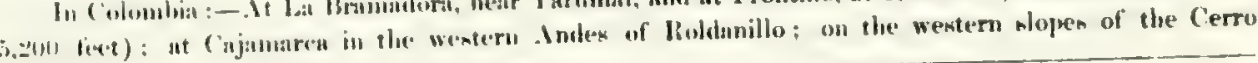

lisplanation of P'late:

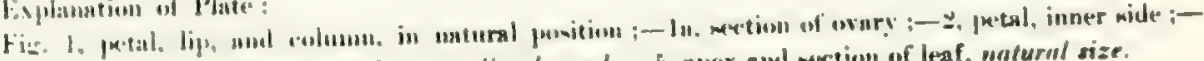

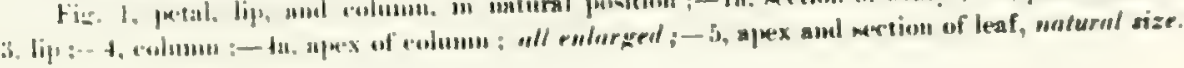





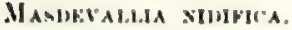

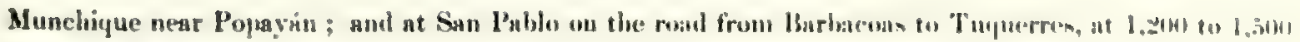
mètre: $(3,900$ to 4,875 feet).

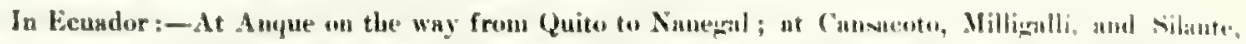

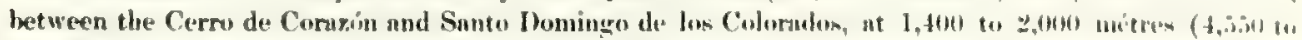

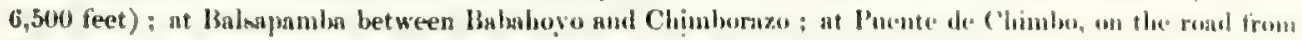

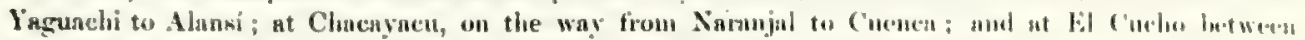
Santa Rosu and Zarunu, at an elevation of 500 to 600 mitres ( 1.625 to 1.950 fiet).

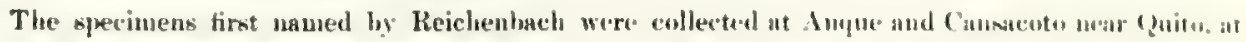

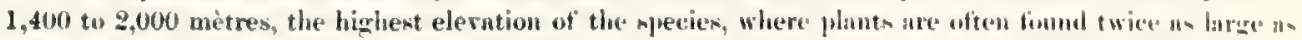

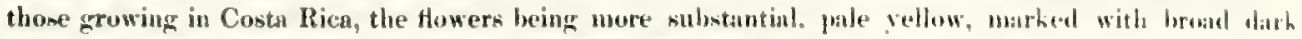

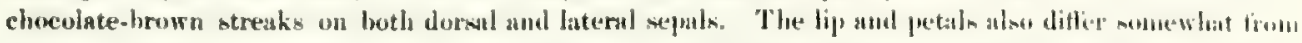

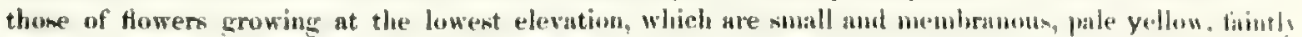

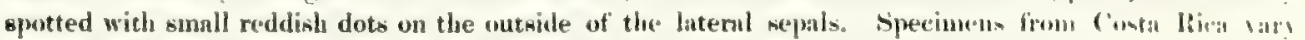
alightly from the Colombian planto, and considersibly from thome foumd in betudus.

12. nidifica zrows ou trees and also on walls of rock. The climate is always dimp, and an thre are but tew days without min during the yenr, the atmosphice is suturated with mointure. 




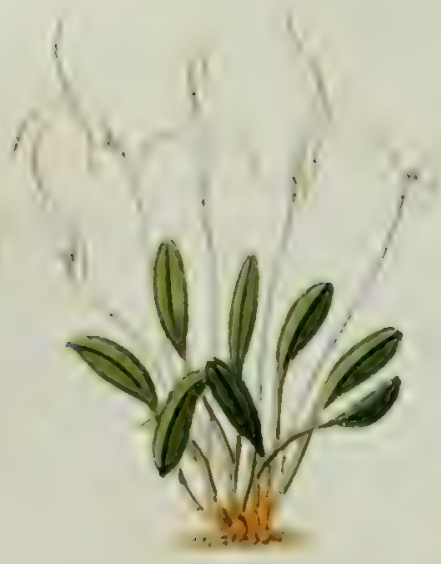




\section{MASIOEVALTIA OPHIOGLOSSA Rehb. f.}

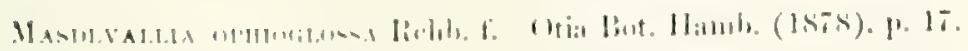

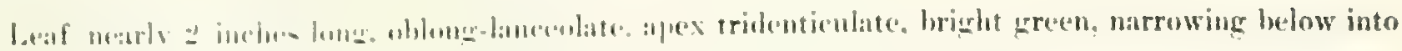

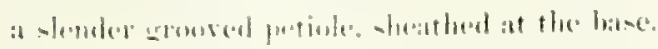

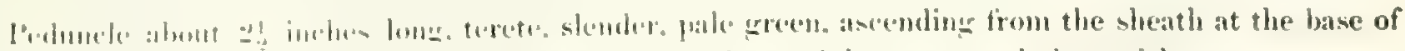

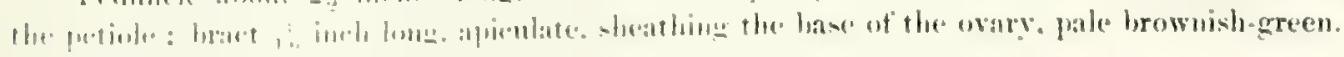

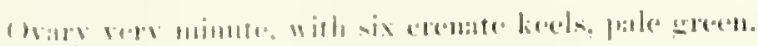

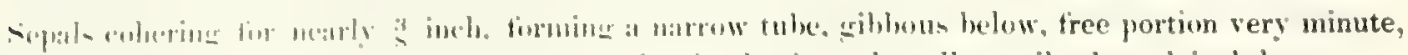

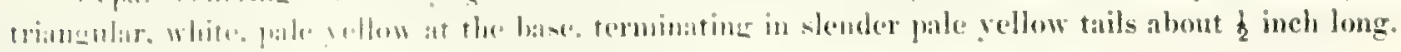

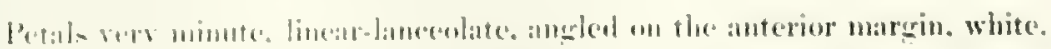

Lip a lirele longer than the pertals, united by a hinge to the curved foot of the column, cordate-oblong,

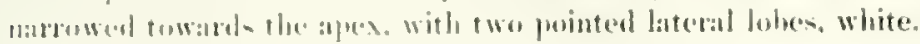

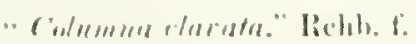

$\mathrm{M}$

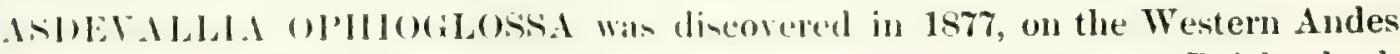
of ()uito, h ('msul Lehmam. Who sent dried specomens to Professor Reichenbach to he named and deseriled. This species has never been in cultivation, nor has any drawing of it hitherto berol published, and wo are indelsted to Mr. Lehmann for the aceompansm Plate. a well as for information respectine its habitat. He found the plant in Eonalor. Erowing on sterp walls of voleanic rock in thick damp woods near (yuto. and alon near sibunte and ('anzacoto on the western slopes of the Cerro del

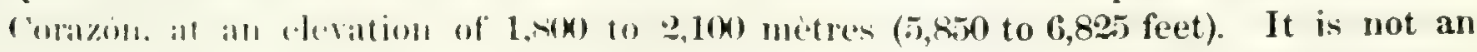
umenmmon phmt, and flowers from the middle of .January to the end of March, somefime in smat profunion. In the Buissier Iterbarium there are fine specimens found in Hor - sume locality hy (omsul Lehmann, and named by him rar. maximn.

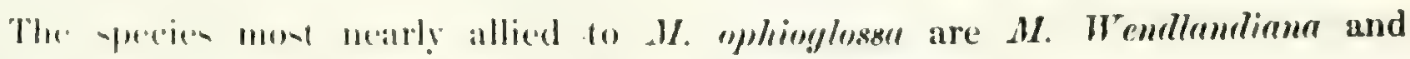
./. premile. of which the latter is uot at present in cultivation.

Evplanation of l'late, from a drawing he Comsul Jehmann:

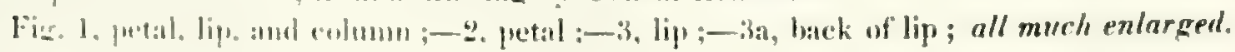






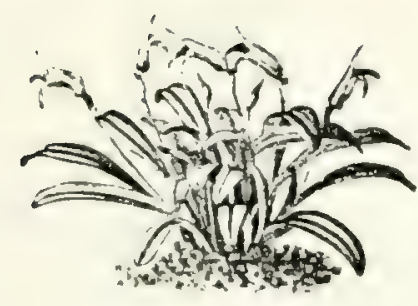

\section{MASIDETILLIA WENIILANDIANA Rchb. f.}

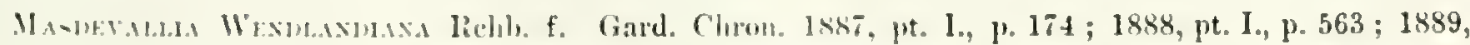

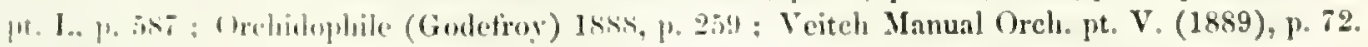

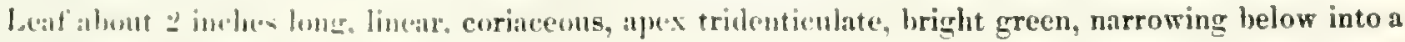

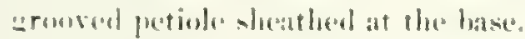

Pnduncle a litth longer than the lenves, very shomer, terete, with two sheathing bracts, very pale

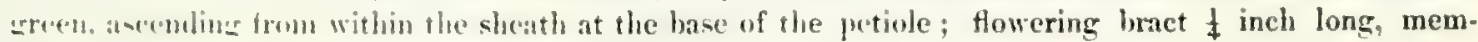
bramous, apheulate, sleatling helow, pale hrownish-green.

Wary nearly ! inch longr, with six grooves, falc sreen.

Sopals: florsal sipal united to the latersal sepals for about 1 inch, forming a narrow tube, gibbous

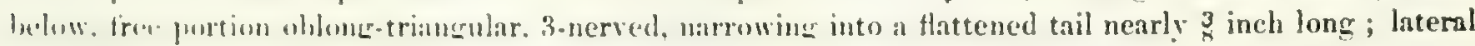

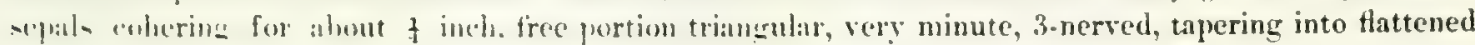

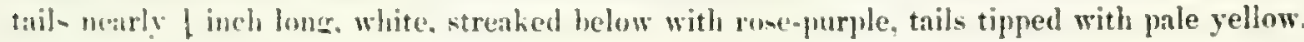

betal-a little more than ! inch fong, ohlons. alpiculate. slightly thickened and angled on the anterior martin. white.

Lif a litele longer than the petals, oblong, groosed, united to the foot of the column by a Hexible linece with iwo lonerimelinal licels near the centre, dull white. semi-transparent, with minute crimson spots, ngex yollow spested with crimson.

Colum not guite a lens an the fretals, white, mangined with crimson, apex denticulate, foot crimson.

ASIEY LLIA WESILANDIANA was imported by Mr. F. Sander from Frontimo, in Intioguia. and was fist described by Professor Reichenbach in 1887. I lave no information as to the elevation or temperature of its habitat, but in cultivation it is fommd to refpuire greater heat than most Hasdevalias, with an equal amount of moisture. It appears to be very nearly allied to $M$. pmilu, M. tubulosn, and $M$. minutn, amb mal ultimately prove to be identical with at least one of these species.

Foxplanation of l'late, drawn from a plant at Newbattle Abbey :

Fir. 1. petal, lip, and colum ; - 1a, section of ovary :-2, petal, inner side ; -3 , lip ; 4 , column ; f: spex of columm :-i, apex and section of leat, all enlarged. 



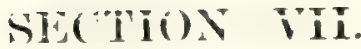

\section{MISCOSAS.}

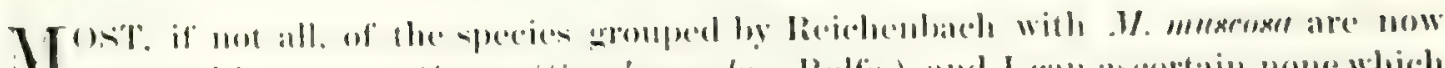

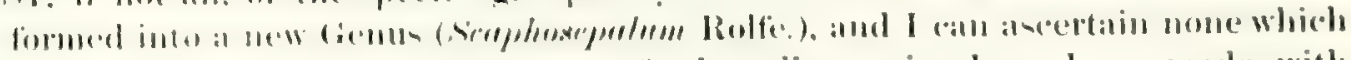

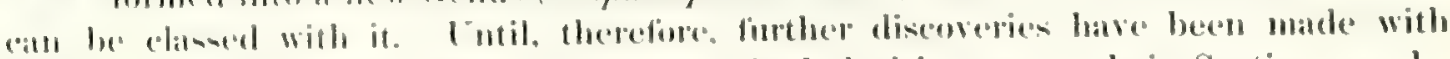
rengad to these pather obseture plants. no final decision as to their Section can be arrived att.

1 species figured:

Mindevallia muscosa Rehb. fo 




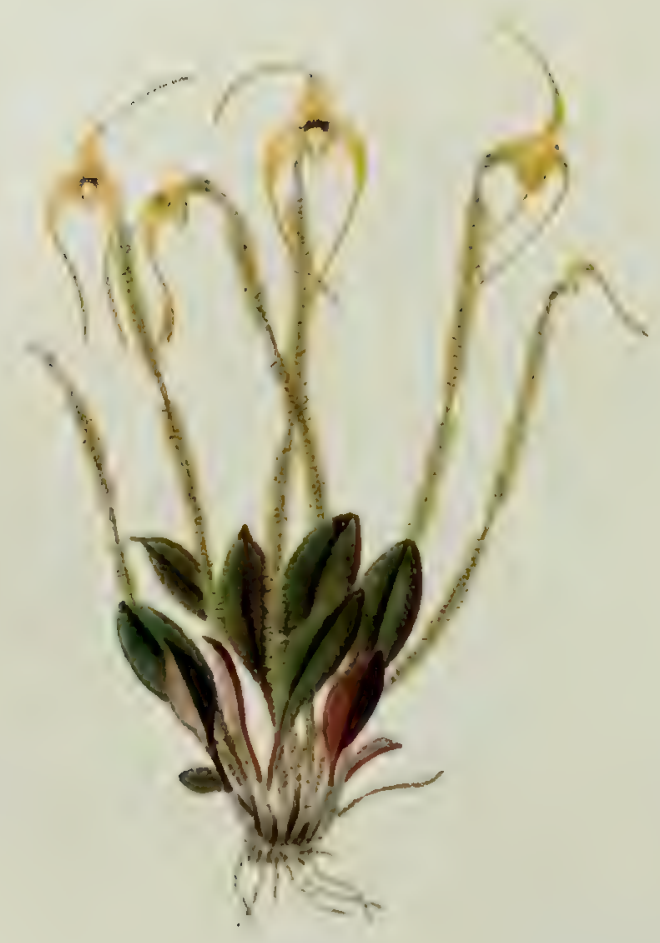

9

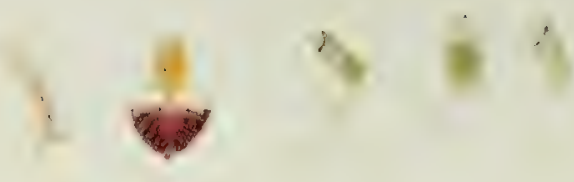


to escape from its prison, would more easily force its way out from the upper -idle, probably dislodging the anther in its struggles. The same fly, with the anthem andlering to it, alighting upon the lip of a second flower and again imprisoned. must, by it mos.. ments, bring the anthers in contact with the viscid stimmatic surfuce, to which some portion of the pollen-grains would attach themselves. The lip closes of itsclf al dunh and opens again in the morning, showing that the insect designed for the fertilisation of the flower is a diurnal one. When the lip has been made to close by a light touch upun the sensitive portion-the bright yellow central ridge-it remaims closed for twentw w thirty minutes, unless forcibly opened and held down: after that period it wently re-nem.

It should be noticed that the anthers are inserted upon the apes of the colum the

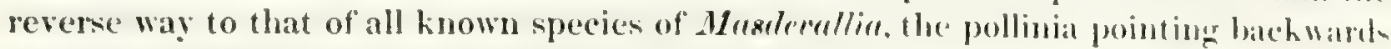
and downwards, so that the rostellum is the most prominent point of the column.

The sensitive nature of the lip was first remathed by Mr. Bean, of the Orehid department in the Royal Gardens, Kew. It is well deseribed in the " (iardeners chroniche" for June 25th, 1887, and still better by Professor Oliver-with exedlent drawing-in the "Aunals of Botany" vol. I. (1857), p. 237.

The upper surface of the leaves is covered with small rounded papillac, hut for what purpose these are intended it is difficult to say.

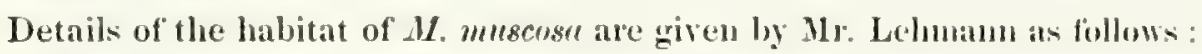

This species has a very wide and irregular greographical dintribution thonuhout bentan and Colombia, extending fully six hundred miles from north to south, and monging vertically from 1 .sm) fw

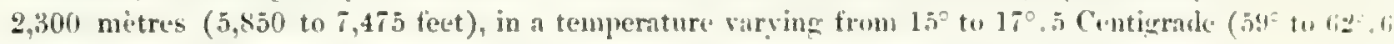
Fahrenheit). Wherever it is found the atmosphere is uniformly damp dming the whole year. It errow.

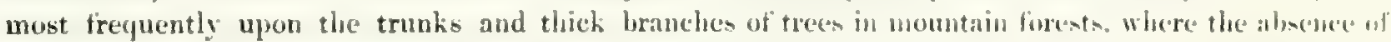
underwood allows a perpetual circulation of air. "The scarcity of such woods accoume for the rarity of the plant, for although found in so many localities it is nowhere common. In many parts of licuator it also grows upon rolcanic rocks and walls of lava, and produces the larrest and most brightly coloured flowers, the flowering seaton being in February and Marcl.

In Ecuador it is chiefly found in the Andes of Quito, on the lsank of the Rio silantes about Millicall,

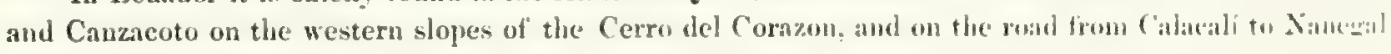
on the Cerro Pululagua.

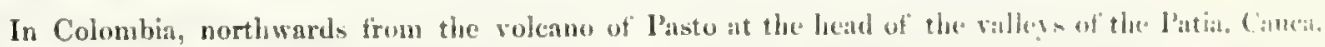
and Magdalena rivers, it occurs almost uninterruptedly as farr north as Santa lawal de (bes, the larumal. Carolina and Amalfi, in the north of Antioguia. In the west of Antioguia it is met with in a few locesliticon the western slopes of the Cordillera at Abriagui f further nouth, aroum l'opavin. it is foumel on the

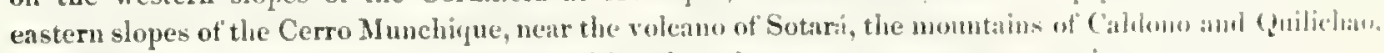
about Tacuavo in the central Cordillera, and in other places too numeroin to mention.

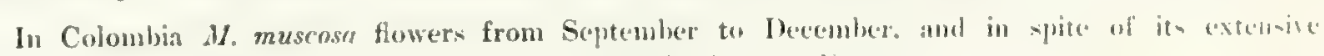
geographical distribution, shows little variation cither in size or colour. 

$M^{\text {ost of the plant included in this Section, of which the greater number are known }}$ only by name. produce more than one flower upon each stem, the flowers of some -pecene expanding at the same time, as in $M$. Schlimii, and of others in succession, as

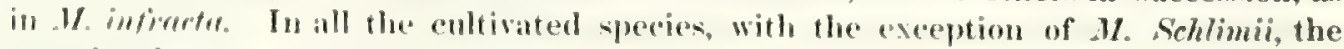
sem in tricuetrons. or tlree-ingled.

11. Forgetimmolattely deseribed by Dr. Krinzlin as at distinct species, is a beautiful vellow variety of $1 \%$. infrocte, and is found in the same habitat, the Organ Mountains, in the sontl of Brazil. not in the north, at stated in Dr. Kraznzlin's account of the plant. 1 received flowers from the Royal Botanic Gardens at Glasnevin, Dublin, in April, 1896, unfortumately too late to be included in my Plate of $\boldsymbol{M}$. infrecta.

I. melenormuther Rehb). f. Bonplandia II. (I854), p. 283; III. (1855), p. 69; Walp. Amin. VI. (1861), p. 1900: Gard. Chron. 1875, pt. II., p. 580 ; 1881, pt. II., p. 336 ; 1895, pt. I., p. 359 , fig. 4ti.- A rare species, which, although known by uame for many yean, has scldom flowered in cultivation, and in not arailable for figuring in this work. The Howrers are villow and dark brown, and are represented in a woodcut in the "(iardemers" Chronicle" for 11 areh estrd. 1895, p. 359, from a plant in Mr. Sander's collection at

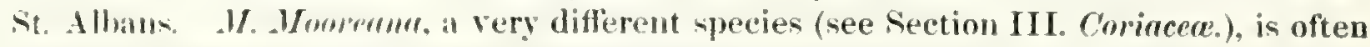
exhibited under the bame of . M. metemormthe, and there is frequent confusion between the two plants. The specimens first described by Reichenbach in 18\%, were collected Wy Lonis Schlim, at Ispasica, near Ocaña, at an elevation of 5.000 feet.

$$
9 \text { species figured: }
$$

Masdevallia aristata Rodrig. (not in crultirution.) auropurpurea Rolib. f.

curtipes Rodrig. (not in cultimation.)

Ephippimu Rehl, t: (=.1\%. Torchilus Liml. of .IT. ('olihri, hort.) Eutctulita Re(h), f.

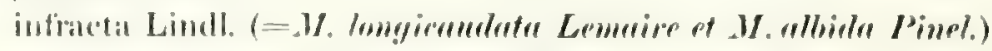

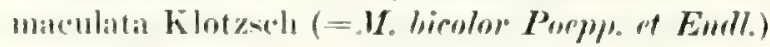

Schlimii Laml.

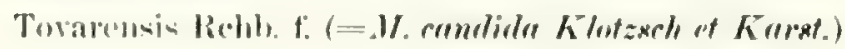

Not in rentrimation:

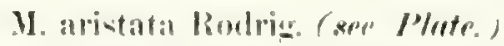

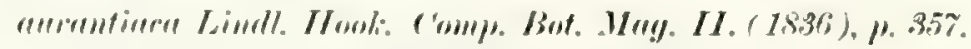

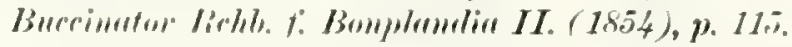

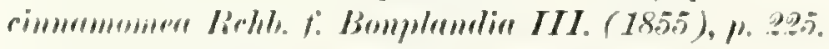

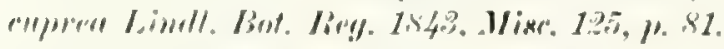

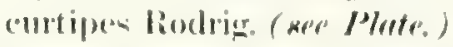
menemetorenthe Limll. Oreh. 1\%. 193.

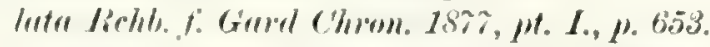

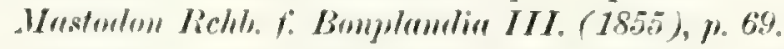

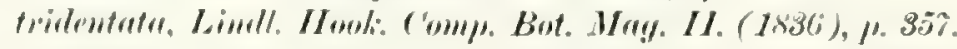

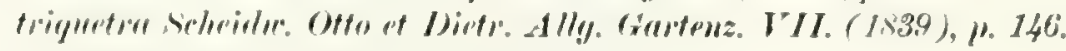

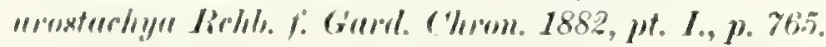

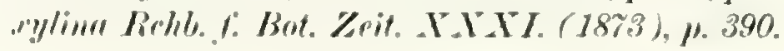





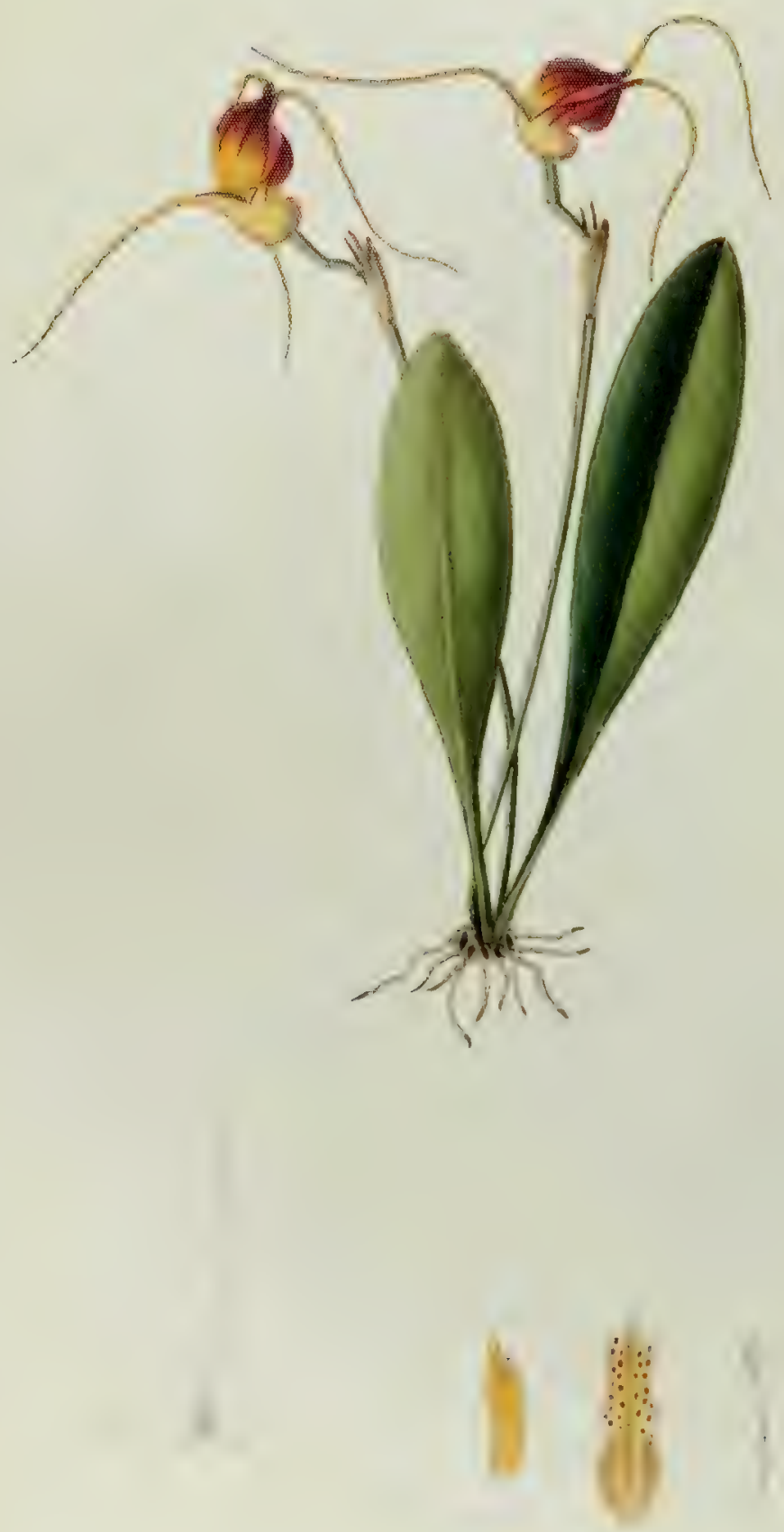


\section{MASDEVALLIA ARISTATA liodrig.}

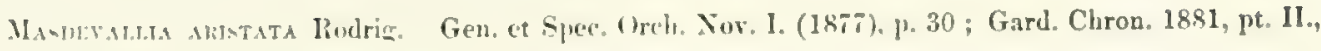
10. $236 \%$

I.cat" tor inches long. oval-lanceolate, dark green, narrowing below into a slender grooved petiole, ajex triblenticulatte.

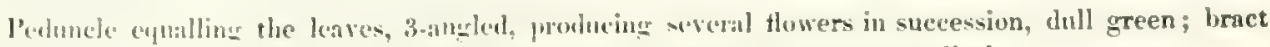
slbunt 3 inch lome. numbranous, dull brown, sheathing the base of the terete pedicel.

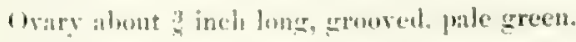

Scpuls colucring. furming a uarrow tube alyout 3 inch long, gibbous below, free portion of dorsal sepal

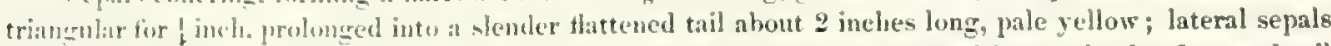
watte-trianalan for inch. 3-nerved. yellow and brownish-crimson, prolonged into a slender flattened tail nesirly inches long.

Petals oblong. apiculate. Alewr, slightly angled on the anterior margin, pale yellow, with minute crima(in) prots.

Lip oblmz. twa-lolual, the anterior lobe oval, apiculate. curved, pale yellow, with crimson spots, which are larecer on the basal halt.

Calum a linte slurter than the petals, white, apex minutely denticulate.

FOR drawing of thim and other Brazilian species, unknown in this country either as

living plants or dried specimens, we are indebted to Señor Barbosa Rodriguez, Director of the Botanic Gardens at Rio de .Taneiro. M. aristutn is allied to $M$. infracta,

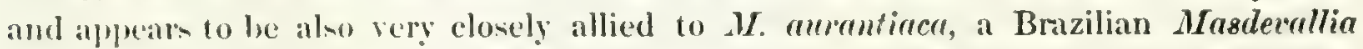
known hy dencription only. Señor Rodrigut'z discovered M. Mristatu in .Tanuary 1876, in the province of Minas (ieracs, where it grows upon mossy rocks, and sonetimes upon treen, in the darh damp recesses of the forests near Caldas. He states that the flowerstem- are feremial, poducing fresh flowers annually, and in his drawing the old flowerstalk- naty be secn appearing above the top of the bract.

The atcompanying Plate is an exact copy of Señor Rodriguez's drawing from nature, intruded hy him for publication in his "Iconographie des Orchidées du Brézil," and referred to in his "Genera et Species Orchidearum novarum" as "tab. 37\%, ined."

Is no fre-h specimens of 11 . migtrutu are available, the original deseription by Señor Rodrigue\% from living plants is here given :

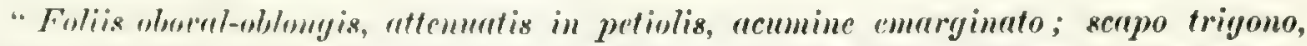
fuliosmu longiturlime; semelis infroctis, dorseli mimori junctis, longe aristatis ; petalis sub-

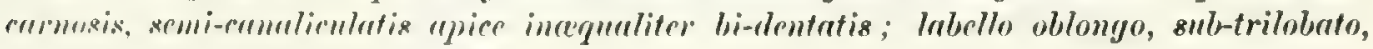
"pice acuto, centro comuliculato."

Explanation of Plate:

Fir. 1, sepals detached and spreal out, natural size ; - 2, petal, inner side ; -3 , lip, front view ;4. lipo side view :-5, coltumn; all enlarged. 



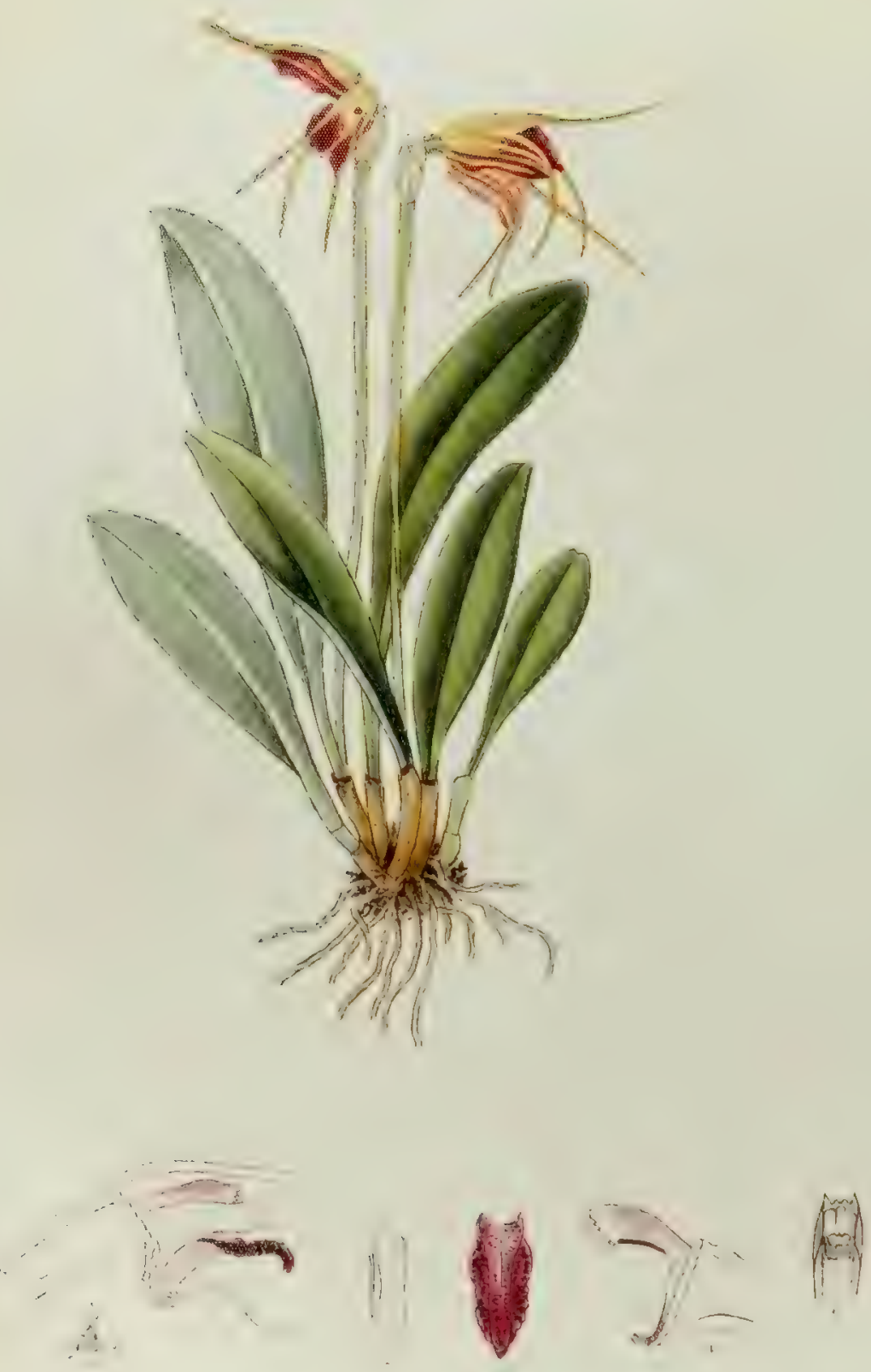


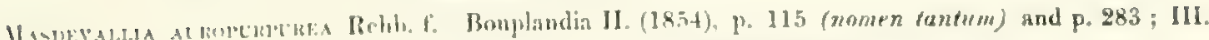
(Isis), p. tist: Walp. Ann. VI. (1861), p. 19:; ()tia Bot. Hamb. p. 17 (1878).

Lesif ahmut : inche- lout. ohlons-lanceulate, carinate, apex tridenticulate, bright freen, narrowing

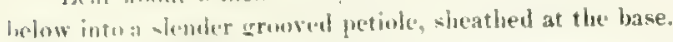

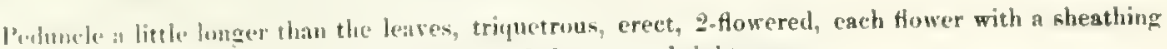
aprenlite unculatanou bract concealing the hase of the ovary, bright green.

Wiry nearly \& imcl, long. curved, with three romded angles and three acute wings, pale green.

sepals: dursal appa! united to the lateral sepals fur about d inch, forming a narrow tube, gibbous

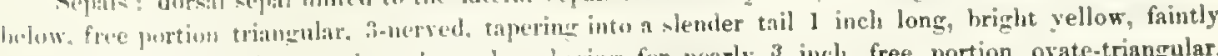
finged with chestunt brown: lateril sepals colneing for nearly 3 incl, free portion ovate-triangular, :B-newat. termintine in slender tails alust! inch loug, bright yellow, tinged with chestnut-brown and veines with green, the imer surlace dark rich brown. and covered with minute papille, the tails yellow and tree'n.

P'ctals 1 inch lome. whlong, apiculate, with a liecl on the anterior margin, white.

lip it listle boner than the petals, united to the curred foot of the column by a flexible hinge,

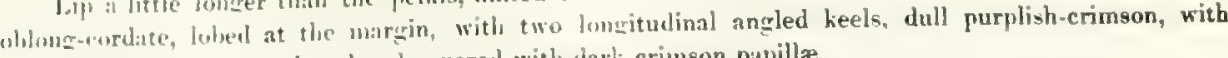
darker yutas the apex retlexpl and covered with diat crinson papilla.

('a)mun thute" that the petals, narrowly winged, white and pale purplish-crimson, apex denticulate.

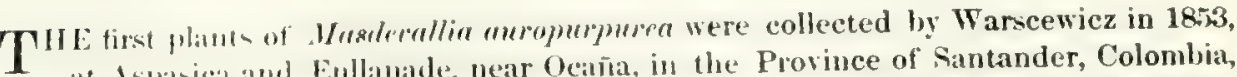
at - Ispanica and Eullauade, near Ocalla, in the Province of Santander, Colombia, at an clevation of 5,000 feet, and for nearly forty years the species was only known from Rechenhach-dencription of these dried specimens. In 1894 a plant was purchased from Mr. Sander, of St. Allans, hy Mr. F. W. Moore, through whose kindness in sending we fresh flowers I am emabled to publish a drawing of the first plant ever seen in cultivation.

The name afrombra is an unpublished name of Reichenbach's for a dark variety of this -yeceies, and the mance utropmerpered is merely a misprint in the index of Walper's Antales for the word amopurpurea.

Our knowledge of the geographical distribution of this species is considerably extended hy Mr. Sander's remark to Mr. Moore that his plant undoubtedly came from Peru-about one thoumat miles south of Ocaña, where it was originally found, and wo or three lumbled miles south of the limit given by Consul Lehmann in the following note:

Musternllia auropurpurea is widely distributed from the north of Colombia southwards into central Ecuador. and is an abundant lout extremely local speries. It grows upon trees in open woods at an eleration of 3,200 to 1,400 mitres (3,900 to 5,850 feet), and in only one locality in Ecuador I have seen it growing upon socks. I have found it on the banks of the Rio Pastaza, on the way from Baños on the Fulean Tunguragua. \& Canalos, in kcuador. In the south of Colombia it is very common all over the hirhlands of lopgyin. On the western slopes of the Central Andes, above Palmira, it grows with M. Ephimpium, and from thence northwards it occurs in an uninterrupted line as far as Pacori and Aguadas, in Intiopuia, being esprecial!y plestiful around Neira and Aranzasu. Along the eastern slopes of the Westem Andes it is to be found in sereral localities, extending as far north as Frontino and Buriticai. It erows in the erreateat alsundance on the Cordillera de Ben Alcarar, between the towns of Cartigo and Caramanti. (In the castern declivities of the Central Andes, which slope towards the basin of the Rio Magdalena, I have seen it in one locality only, in the mountains between Pensilvania and La Victuria.

'I"he mean temperature of the habitat of $M$. aurmpurpuren ranges between $18^{\circ}$ and $20^{\circ}$ Centigrade (ahut fit to $64^{\circ}$ Fahrenheit). The weather during January, February, and March, and again from ouly to September, is very dry ; while the ramfall duriug the rest of the year is extremely heavy.

Rxplanation of PJate, drawn from a plant at the loyal Botanic Gardens, Glasnevin, Dublin :

Fig. 1, petal, lip, and columu, in natural positum;-1a, section of ovary ; 2 , petal, imer side;3. lip ;-t. column ;- fa, apex of columm; all pnlarged. 

$y$ 


\section{MASDEVALLIA CTRTIIES Rodrig.}

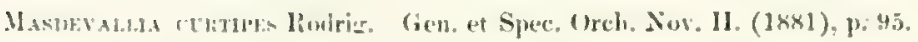

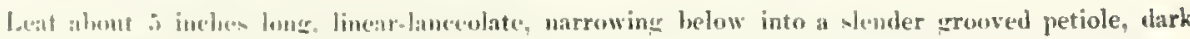
zrexen, alpes tridenticulate.

Pesluncle, including predicel, shout 1 inch lome, tercte, nscending from the base of the petiole, dark

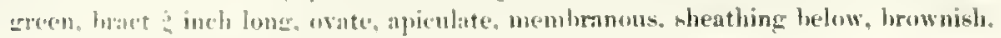

Bury I inch lourg. with six groures, whitioli-green.

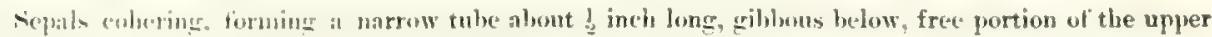
sepal very slourt trisngular. :-nerved. termimating in a slender tail nearly 1 inch long; lateral sepals

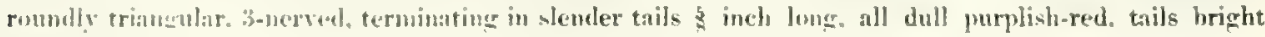
rillow:

l'ctals lincar. with an ande on the anterion margin near the base, apex looked, white spotted with crimsin.

Lip whlone. with rommled lateral lobes, aljex lincuiform, acute, recurved, with minute central piluillie. white.

('olum very thich, shorter than the pretsls, white. anjex minutely denticulate.

$\mathrm{M}^{\lambda}$

ASI)EVALLIA C'CRTIPES was diseovered in 1879 by Senhor Barbosa Rodriguez, in the damp unexploned forests of Rodeio, a few miles north of Rio de Janeiro, flowering in May and June. No drawing of this curions little plant has hitherto been published, the aceompanying late being a copy of a drawing from nature prepared by Senhor liodriguez for his great work on the Orehids of Brazil, not yet completed. 1I. crefiges is at prencut unknown in this comutry, the only Brazilian species in cultivation being 12. inforefo, from which it differs considerably in the extreme shortness of its flower-stalk and in the dull uniform colour of its flowers.

The original deseription by Senhor Rodriguez is as follows:

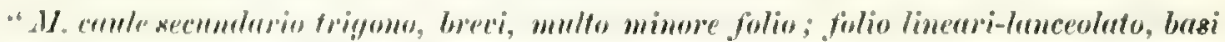

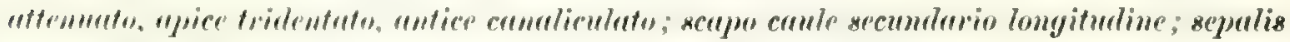

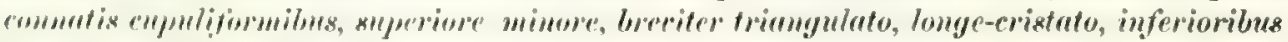

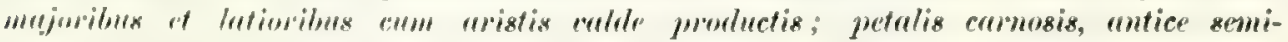

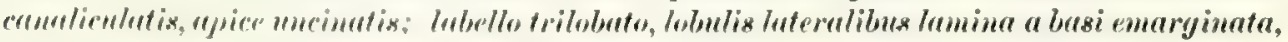

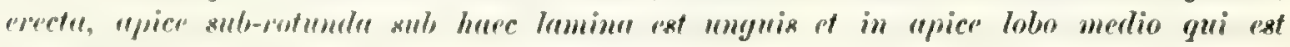

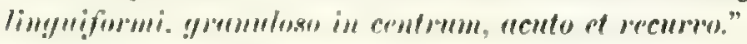

lixplanation of I'tate:

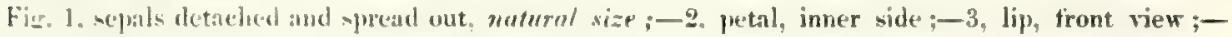

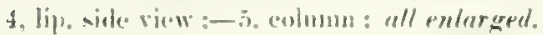






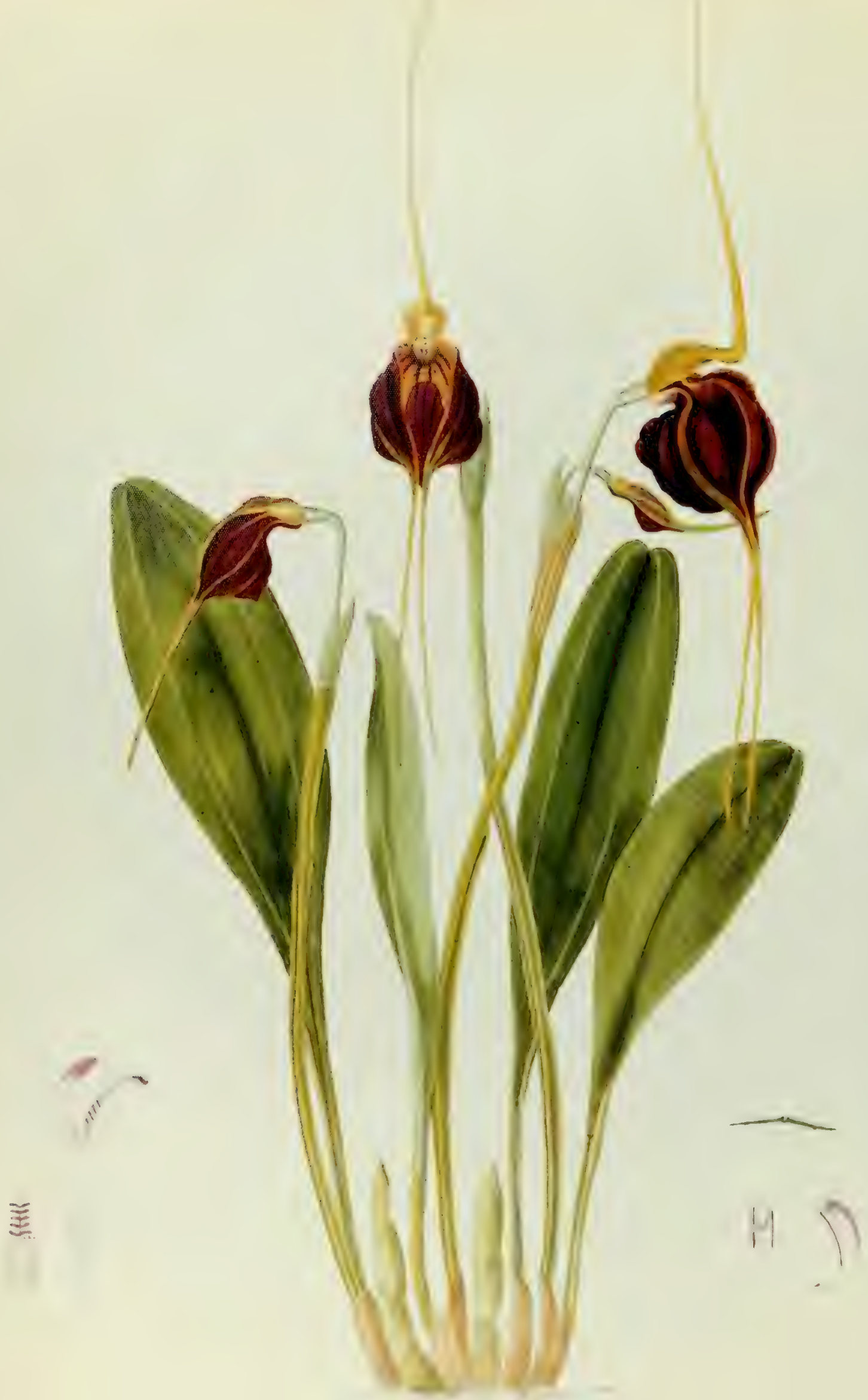




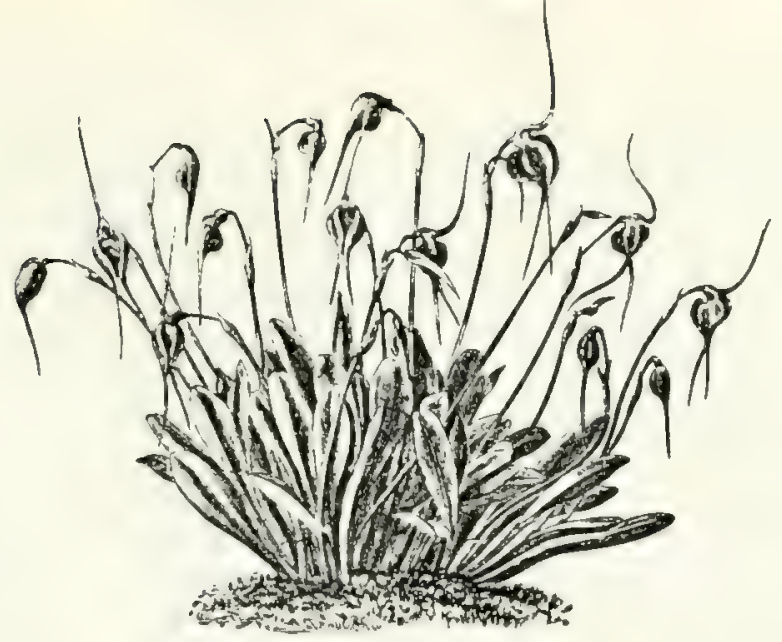

MASDEVALLIA EPHIPPIUM Rchb. f.

Masnevallia Ephippiun Relub. f. Bot. Zeit. 18i3, p. 390 ; Xenia Orch. rol. II. (1874), p. 213, t. 195; Gard. Cliron. 18it. pt. I., p. 372; 1881, pt. II., p. 236; Bot. Mag. t. 6208, (1876).

11. Treclitus Lind. Illustr. Hort. vol. XXI. (18i4), p. 136, t. 180 ; Gard. Chron. 1873, p. 711 ; 1875, pt. I., p. 504 ; 18si, pt. II., p. 110 ; Floral Mag. 1881, t. 443.

14. Colibri Hort. Burbidge Florist and Pomol. 18i33, p. 3 ; Gard. Chron. 1885, pt. I., p. 174.

Var. acrochordonin=Mastevallia acrnchordonia Rchb. f. Xenia Orch. vol. II. (18i4), p. 213; Gard. Chron. 1885, pt. I., p. 174; Orchidophile (Godefroy) 1885, p. 199.

Leaf 5 to 10 inclies longr, 1 or $1 \frac{1}{2}$ inch broad, oblanceolate, minutely tridenticulate, narrowing below into a slender grooved petiole, shenthed at the base, bright green.

Peduncle 10 or 12 inches long, many-flowered, ench flower falling off before the expansion of the next, ascending from within a sheath at the hase of the petiole, ncutely angled, angles from one to five, most freyuently three; brichit green: flowering bract l inch, or more, long, sheathing, apiculate, pale ereen.

Ovary 1 to 3 inch long, triangular, with six deep groores, bright green.

Sepals: dorsal sepal united to the lateral sepals for 3 inch, forming a narrow curved tube, ovate for about $\frac{1}{2}$ inch, cucullate, 3 -nerved, yellow, with minute brown spots, narroring into a tail 4 or 5 inches long, vellow, greenish at the back ; lateral sepals cohering for nearly two inches, much inflated, 3 -nerved, nerve depresed, witls the intervening spaces much distended, colour on the exterior crimson-brown with areenish nerves, on the interior yellow closely covered with small crimson spots, rich crimson near the tube, the nerves thickly studded with large, irregular warts; terminating abruptly in slender tails 3 or 4 inches long, meeting at the lase, diverging towards the extremity, gellow, greenish at the back.

Petals ahout 1 inch long, oblongr, apiculate, with a prominent keel on the anterior margin terminating in a small angle, and a smaller keel near the opposite margin, white.

Lip a little more than $\frac{1}{1}$ inch long, grooved at the hase, with two triangular lateral lobes, obovate towards the acute apex, white, spotted and harred with crimson.

Column about 1 inch lone, narrowly winged. apex denticulate, white, with wings and back rosecrimson.

THE discoserer of Mnselemllin Ephiphium was undoubtedly Gustav Wallis, in 186s, although the discovery is sometimes ascribed to Dr. Krause, as late us the year 1873. In the Gardencrs Chronicle, 1875 , pt. I., p. 504, an interesting account of the discovery of $\boldsymbol{U}$. Enhiphimm, under the synonym of $\boldsymbol{M}$. Trochilus, is given by Wallis, 

who is considered to be a most aceurate and trustworth observer and nambor. "This Matavallia having been discovered by me, it may be interenting if I communicate some olservations respecting it. In the gear 1868 I first met with this plant, growne in the frosty heights of the Sonson district in New Grenada. The whole of the plants which I then remitted to Europe died, and I afterwards sent others in the year Inis, to 1 ons. Linden of Brussels. M. Trochilus suffes greatly from tropical heat, and from exees of heat generally: Only a dozen out of 200 plants arrived in Europe the fimt time-I brought them under my" personal care. The name 'Colihri,' which is given to this plant in its native country, is simply an allusion to the fantastic birch-like apprearanee of the Hower-though this allusion is rather far-fetched, as are so many of the allusions in use ly the Sonth Americans, especially the Indians. . . . . . . The grencral size of the flower does not surpass that of a wahut. The winged sepals have a length of about 4 or 5 inches each. There is a peculiarity of the plant well worth mentioning, and that is its power of producing out of the same spathe several subecinent flowers. I olsserved many plants in my stores that produced flowers out of the old stalks, which I had considered as being dead. It is possible, therefore, that this Musdrerellin in its native place has two flowering seasons each gear. The stromg and companctly-formed root-balls get sometimes to a considemble size and weight. The plant, being once established, must possess an extraordinary vital power. The flower-stalks are exceedingly strong, and have in section a well-marked triangular outline; the leaves are of a bright green colour, short and strong, and of an unusual thickness-the term coriaceous will not suffice for them. M. Trochilus has the happy faculty of growing and doing well under any conditions. It grows quite as well in a loose compost as on the bark of trees, or on decomposed pices of trunk, and even in a common heary soil. The amateur Orchid-grower will also appreciate its habit of growing in highly elevated

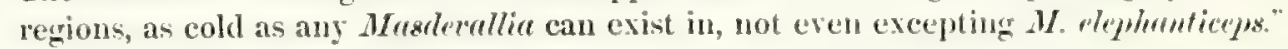

The long interval which elapsed between the discovery of Mastlemollie Eyphimpinum in 1868 and the publication of the first description in 1873 , can only be accounted for by the fact that the whole of Wallis's first importation of plants perinhed, and that, apparently, he sent home no dried specimens of the flower. The specien applears to have been known to Mons. Linden and others as M. Trochilus for some time previou to the publication of Profesisor Reichenbachs description under the name of Ephippiom in 1873; although no description of the plant under the name of Trochilins wat: published until 1874

I am informed by Cousul Lehmann that the plant found by Dr. Kauue at Loja (formerly Loxa) was the small-flowered variety covolemelomie, named and dencribed by Professor Reichenbach as a distiuct species. Consul Lehmann, howerer, considers this plant to be merely a local variety peculiar to the enstern slopes of the Andes, the type, MI. Ephippinm, being found upon the western slopes. A careful examination of the two plants reveals only very slight differences letween them, the flowers of acrocherelonien being always smaller and sometimes less globular than those of $\boldsymbol{M}$. Ephimpimm, and having the lip and petals slightly narrower and more pointed. The remarkable wartlike processes along the inuer surface of the nerves of the latcral sepals are expuall! present in both plants, although entirely overlooked by Profesor Reichenbald in hidescription of $\boldsymbol{M}$. Ephippiun.

Consul Lehmann gives the localities in which he has found the two phants in the following note :

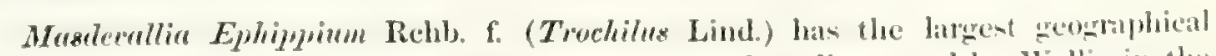
distribution of any. Mregdeculle kuown to me. It was first discovered by Walli- in the State of Antioquia in Colombia, where it grows at various places at an clevations of 1,800 to 2,200 metres above the sea $(5,850$ to 7,150 feet $)$, and in lute but not very dense woods, high on trees. From Antioquia the fist specimens were introduced into linrope. In 1877 it was olserved by myself all along the western slopes of the Centul Auden of 

the State of Cauca, as far south as the voleano of Sotari, near Popayan. In the vicinity of Popatyan it attains the largest proportions, both in masses of root and in the size of the Howers. Masses measuring 40 or 50 centimetres (16 or 20 inches) across are frequently met with. About three years ago (1886) I also found the variety acrochordonin on the castern declivities of the Eastern Andes of Cuenca, in Ecuador. The plants from that locality are much smaller, and the flowers only about half the size of those of 11. Fiphippinu in Colombia.

11. Ephippim is never found growing in great abundance over a large area. It invariably occupies small localities-perhaps a small portion of a mountain slope-and will not be met with again for a great distance.

The anmual mean temperature ranges between $15^{\circ}$ and $18^{\circ}$ Centigrade $\left(59^{\circ}\right.$ and $\left(i^{*}+\right.$ Fahrenheit), according to the region.

F. C. Lemmank.

Explanation of Plate, drawn frum a plant at Newbattle Abbey :

Fig. 1, petal, lip, and column, in naturnl position;-1a, section of ovary ; 2 , petal, inner side ; 3. lip :-4, column:-4a, npex of column; all enlurged; -5 , apex and section of leaf, natural size. 


$\forall$ 


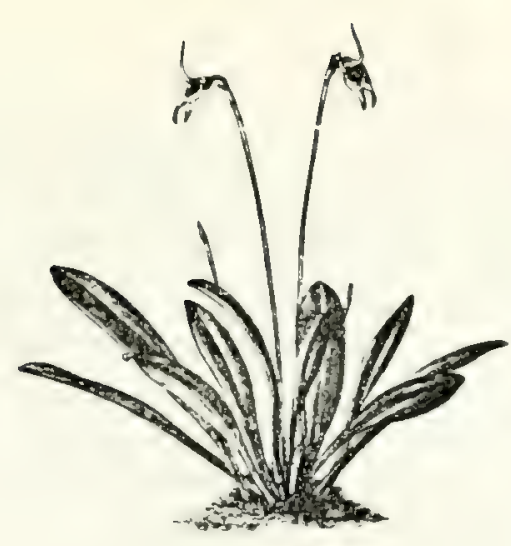

\section{MASDEVALLIA GU'TULATA Rchb. f.}

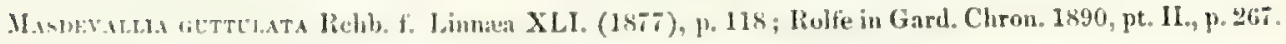

Leaf about inches long and a inch wide, oblong. apex tridenticulate, bright green, narrowing below into it sender scrooved petiole, shenthed at the base, pale green.

Pealuncle (i to lo inches longe, ereet, 3-angled, bright sreen, many-fluwered, each flower falling off before the expansion of the next; Howering bract alyout 3 inch long, slieathing below, carinate, apiculate, hruแni-h-ยret?.

Wary wearly $\frac{1}{4}$ inch hong, curved, rounded, with six grooves, pale green.

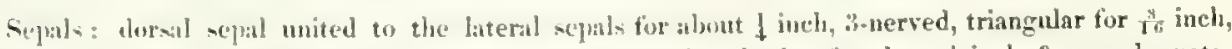

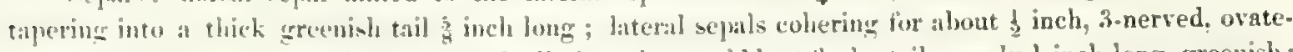
triangular for b inch. tipering very gradually inta flattened blunt theslyy tails nearly $t$ inch long, greenish; all the sepals dull white, with numerous small tufts of short crimson hairs upon the inner surface, nerves yellowish, prouninest on the anter surface.

L'etals, inch long, hincalloblong, appiculate, pale yelluw, with a crimson keel near the anterior margin.

Lip alhunt the length of the petals, grooved, fheshy and cordate at the base, and united to the foot of

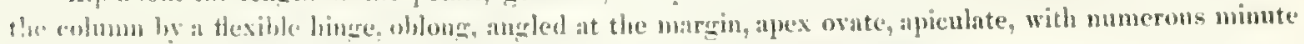

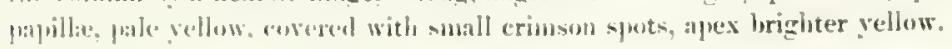

('dulum a bitcle shorter than the petals, harrowly winged, apex scarcely dentate, very pale green,

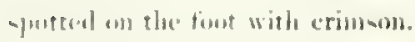

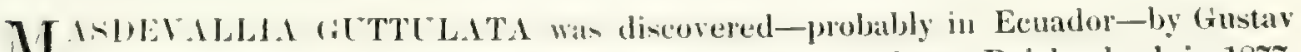
II: allis, whose dried specimens were described by Professor Reichenbach in $187 \%$. Is lattely ats 1s: it was again described by Mr. R. A. Rolfe, of the Royal Herbarium, Ken, who then comsidered it to be at new species. It is still rare and little-known, and to be foum in only a few collections in this country, perhaps owing to its being extremely focal in its native hathitat. I have received several specimens from Mr. F. W. Moore, of fibanevin, Duldin, whone phut furnished the photograph for the accompanying woodent. Iesirs. Sexurer and Tropp, alno, with rare generosity, forwarded to me a living plant in full flower, a most valuable assistance in the completion of my drawings.

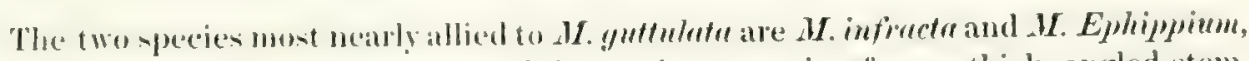
which it rescublen in proflucing seretal flowers in suceession from a thick, angled stem. I curvour feature, hitherto umoticed in any botanical description of this plant, is the

Easplanation of l'bate:

lFis. 1. petal, lip. and column, in natural position;-la, section of urary ;-ž, petal, inner side ;

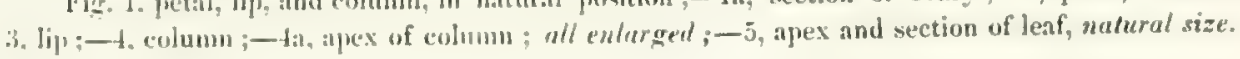




$$
\text { . }
$$


presence of little tufts of stiff hais scattered over the immer surfine of the sephl. and

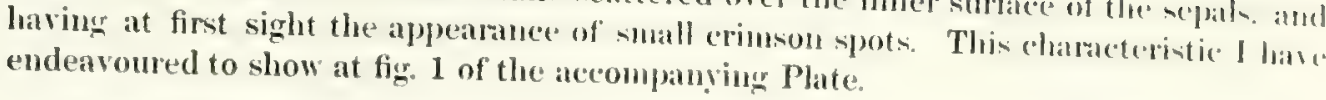

Consul Lehmann, who appear to be almost the only collecen of this specien since its discovery by Wallis, gives the following information:

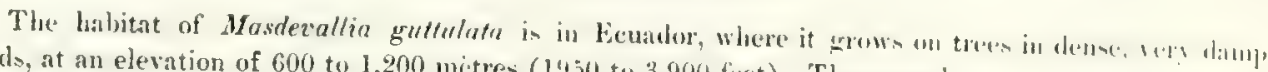

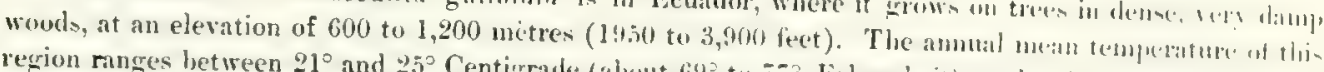

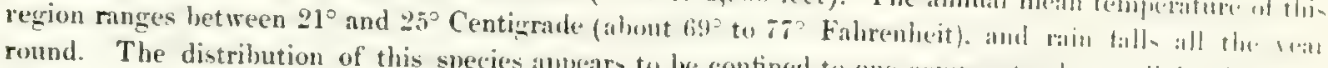

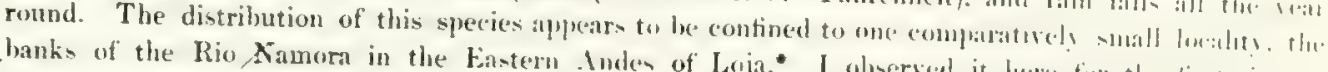

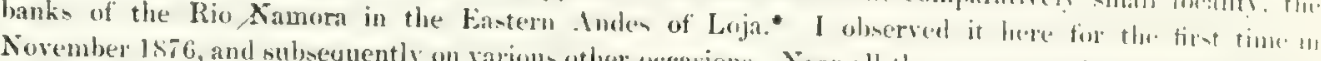

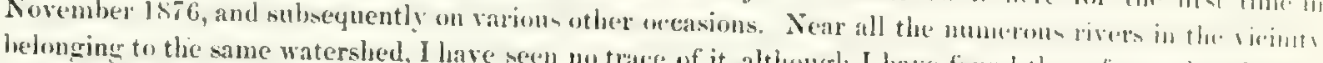

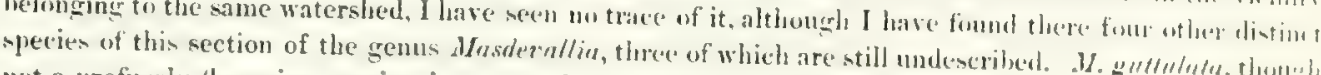

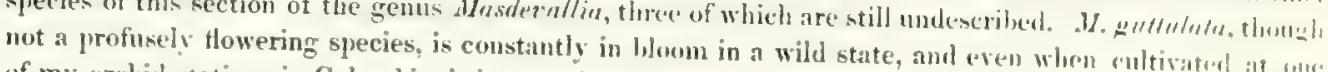

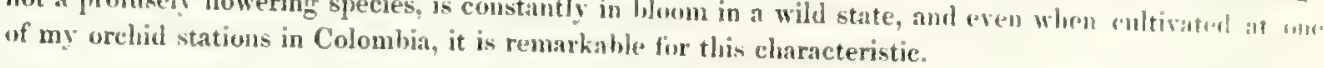

- I am infurmed by $\mathbf{M r}$. William Bull that he has received this species "fiom the ocania diatrict"more than nine hundred miles north-east of Loja.-F. H. W. 

. 

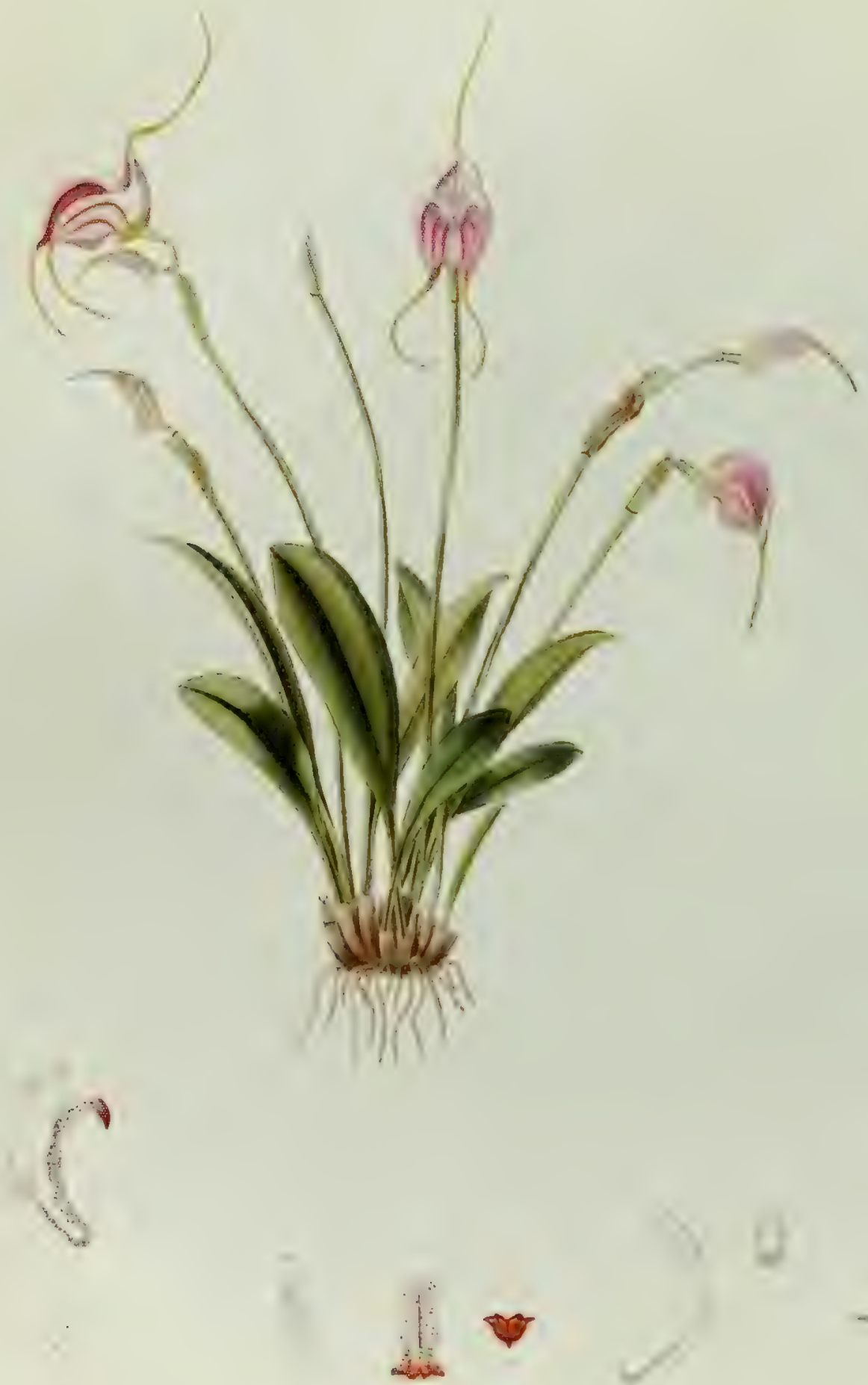


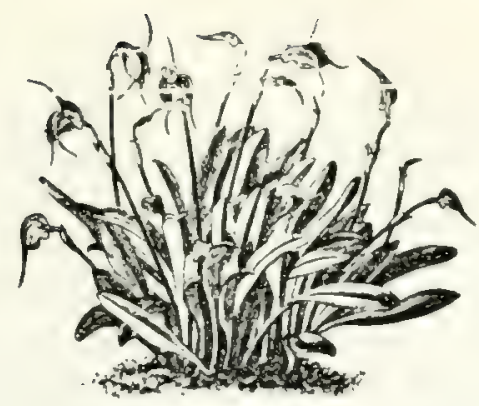

\section{MASDEVALLIA INFRACTA Lindl.}

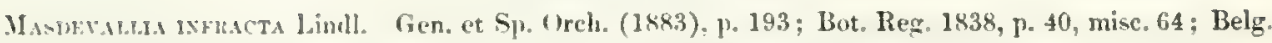
Hort. XXIII. (1873), p. 35\%. t. XXII; Flore des Serres, vol. XXIII. (1880), p. 43, t. 2389; Gard.

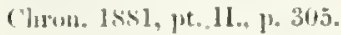

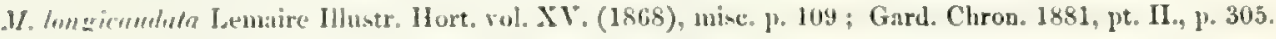
W. alliell Yinc] MSS. file Lemaire Illustr. Hort. rol. XV. (1868), misc. p. 109.

Tru, purpurm Rchl. f. Gard. Chron. Iks3, pt. II., 1. 460 ; (Orchidophile (Godefroy) rol I. (1883), p.761.

Lent 4 ur 5 inches loner. about $\$$ inch wide, oblong-lanceolate, fleshy, apex tridenticulate, bright green, vary shining. narrowing into a slender grooved petiole, palte green.

Polumcle 6 ; or $s$ inches long, erect, somctimes terete, more often angled, briglt green, many-flowered, each Hower falling off hefore the expansion of the next; hracts about $\frac{Z}{1}$ inch long, carinate, apiculate, lieathine below, orate abuve, bright green or brownish.

Orary abut 1 incli long, with three broad and three narrow rounded angles, whitish or pale green.

Sepals: dorsal seyal united to the lateral sopals for about 1 inch, forming a wide tube, free portion triangular-ovate for about 3 inch, 3-nerved, cucullate, purplish-pink, terminating in a slender tail $1 \frac{1}{2}$ inch

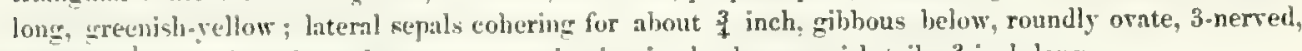
purplish-pink. darker along the nerves, terminating in slender greenish tails. 3 inch long.

L'tuls alout $\frac{1}{4}$ inch long, linear, apiculate, anterior margin slightly keeled, inner surface viscid below the kecel. white, with pale piuk sprots, apex pale vellow.

Lij alwut $\frac{1}{1}$ inch long. oblong-pandmate. angled and keeled, margins and apex reflexed, dull pink with muncrum crima(m) spots. apex dull orange and crimson.

Columm nc:arly + inch long, narrowly whinged, white and pale green, apex crenate.

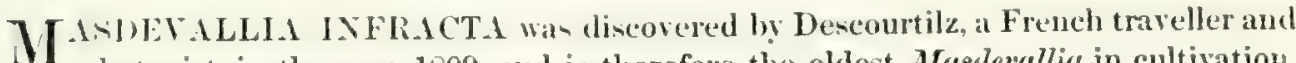
botanist, in the rear 1809 , and is therefore the oldest Mroslevellin in cultivation. the only vereien discovered at an earlier date being the Peruvian $M$. miffora, upon which the gentw was founded in 1798 by Ruiz and Pavon. This species is now of uncertain identity. and was never introduced into cultivation.

The tirst imported plants of $\boldsymbol{M}$. infreta were probably those sent to Paris in 1828 by Jons. Pinel, a resident near Rio de .Janeiro. These plants were supplied to him by Inol, who, during his evplomtions in the surrounding country, collected them at Peuna war Canta Gallo. I druwing of the plant was made in $183+b y$ a daughter of Mons. Pinel, and published thirty years afterwards in "L'Illustration Horticole," by the Editor, Mons. Lemaire, who thourht fit to subntitute the specific name longicaudutu for that of albida, nnder which the drawing was sent to him. The first description of $M$. infracta was published by Dr: Lindley in Mareh, 18:3.

Explanation of" I'late, drawn trom a l'Jant at Newbattle Nbbey:

Fig. 1, petsl. lip, and columu. in matural position;-13, section of ovary ; - 2, petal, inner side ; 3. lij :-4. columu:- - ta. apex of column; nll enlarged:-5, apex and section of leaf, nafural size. 

In 1836 the plant was found by Dr. Gardner, who sent home numerous dried specimens, some of which are preserved in the Britisls Museum of Natural llintory, and others-together with a drawing by the collector-in the Royal Herlarim, Kew. The

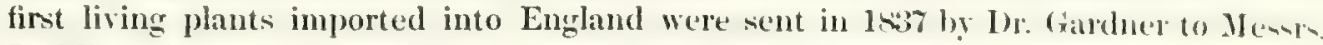
Loddiges, in whose establishment at Hackney they flowered the following year.

Tariations occasionally occur in the colour of the flowers, and onc variety, introduced by Mr. Bull, was named by Professor Reichenbach ror. purpurer. It has large flower of an uniform shade of violet-purple. In some plants the winged or angled stem. chancteristic of most species allied to $M$. infrecte, is replaced by a slender rounded stent

The only known habitat of $\boldsymbol{M}$. infrect is Brazil, where it is found in the mountain. called bythe Portuguese Serra dos Orginos, or Organ Mountains, from a fancied resenblance. of their granite peaks to the pipes of an organ. These peaks form part of a momutin range situated about sixty miles to the north of Rio de Janeiro, branching out in variou directions, and stretching from near Bahia in lat. $12^{\circ} \mathrm{S}$., to S. Catharina in lat. 29 $\mathrm{S}$ Many small rivers take their rise in the Organ Mountains, spreading into wide clear poes. and traversing valleys of deep rich alluvial soil before falling into the Bay of Rio. The sides of the mountains are clothed with forest trees of large size, and upon the mons stems and branches, as well as on the sides of banks, $\boldsymbol{M}$. infrectu was found in alundance by Dr. Gardner, flowering from November to January. All the steeper declivities are overspread with beatiful flowering shrubs, the summits of the smaller peakis loing composed of enormous loose blocks of granite covered with lichens and small Orchids. The summit of the highest peak, about 7,500 feet above the level of the seat, is formed of one broad flat surface of granite of considerable extent, bare for the most part, but here and there covered with small stunted shrubs, and showing many little excavations in the surface, filled with excellent water.

The temperature duriug the cool months of May and June is sometimes as low as 32 ' just before daybreak, but in the hot and raing months of Junuary and Felmany it rises to 81 at noon. Violent thunder-storms occur almost daily, coming on recrulan! at 4 p.m., and leaving the evening atmosphere fresh and cool.

The above description of the Organ Mountains is taken from Dr. Gardner's "Travels in Brazil," published in 1849. 




$$
v
$$




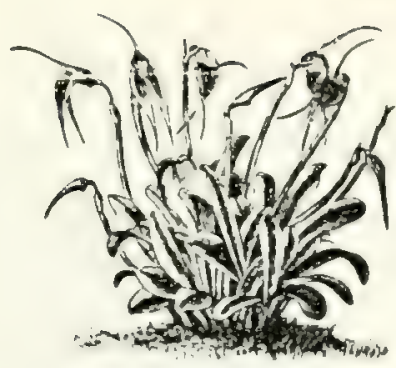

\section{MASDEVALLIA MACULATA Klotzsch.}

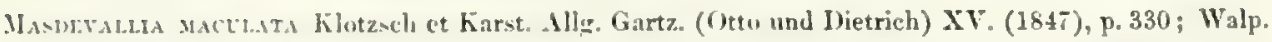
Inn. I. (1\$49), 1).7.t; VI. (1\$61), p. 190; Bunplandia II. (1854), p. 23; Belg. Hort. XXIII. (1873), 1). 35!! : Flure des Serres t. 2150 (1875) ; Gard. Chron. 1848, p. 103; 1881, pt. II., p. 336 ; Veiteh Ianual (Preh. pt. V. (18\$i), p. 51 .

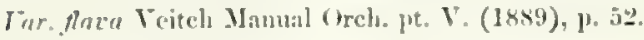

Leaf 6 or 7 inches long, linear-lanceolate, slightly carinate. ajex tridenticulate, bright greed, narrowing Inelow into a errored periole, sheathed at the base.

Peduncle s' or 10 inches lone, sharply angled (angles two, three, or four), producing several flowers, "mch Hower fulling oft" before the expausion of the next, bright green; flowering bract about 1 inch long, carinate. apiculate, fable grecen, sheathing the numerous buds and the base of the terete reddish pedicel.

() )ars" allout $\frac{1}{4}$ inch long, with three rounded angles and three wings, pale green.

Sepals: dorsil mepal united to the lateral sepals for alout 5 inch, forming a narrow tube, free portion wntc-triangular for 1 inch, 3-nerved, yellow, shaded and spotted with red, tapering into a fleshy flattened tail about 3 inclicw long, bright orange, grecnish at the back; lateral sepals cohering for it inch, oblong ovate, 3.nerved, reddislbvellow at the mirins, crimson in the centre, with dark nerres and spots, tapering into sender pale lemon-coloured trils, 2 inches long.

Petals about I inch long, oblong, apiculate, anterior margin slightly keeled, white and very pale yellow

Lip about $\frac{1}{4}$ inch loug, pandurate, witl two angles, dull purple, spotted with dark crim $\rightarrow$ on, apex rough with dark criman papillax.

Column \& inch long, white, very namowly winet with crimson, apex crenate.

$\mathrm{M}$

ASDEY_LLIA MACTLATA Was discovered by Wagener at La Silla near Caracas,

at an altitude of 8.000 fcet, yrowing in woods on the branches of trees, and flowering

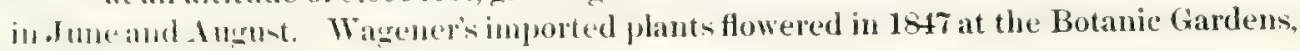
Berlin. for the first time in cultivation.

I well-known variety of $M$. muculalu, cur. flum (of which a flower is represented in the accompanving Plate), has small bright lemon-yellow flowers, tinged inside with reddinlthrown. "The petals, etc, are identical in structure with those of the type, but the colum has none of the purjele shating, and the lip is paler in colour. This variety was imported from Caracas lỵ Jesurs. Sander of St. Albans in 1881.

A nearly allied species-or posibly a form of the same-is $\mathbf{M}$. bicolor, described and figured in lisso hy Poeppig and Endler (Nov. Gen. et sipec. II., p. 6), and found growing on trees in the wook of ('uchero, in the eastern mountains of Peru, flowering in January. It has the angled stem ustal to species of the same section, and flowers of the same colouring as those of $\boldsymbol{M}$. muculutu, but it is a much smaller plant, both leaves and stem being scatrecly four inches in height. Living specimens of $\boldsymbol{M}$. bicolor have never been imported, and until the plant has been re-discovered and carefully examined, its identity with H. meculefe must remain mectain.

Explanation of Plate, drawn from a plant at Sewbattle Abbey :

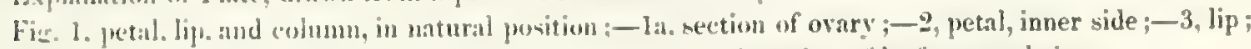

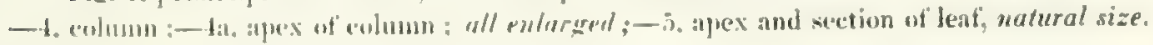



Consul Lehmann gives much additional information as to the climate and focalities in which $M$. maculato is found:

The habitat of Masterallia maculato is in Venezuelat and colombia, at an elevation of 1,400 to 1,700 metres $(4,550$ to 5,525 feet $)$. It flower from A ugust to December, and in cultivation at Popayan it is never without flowers. In Venczuela it grows in the colons of Tovar near Caracas, and in the mountainous parts of the Estado de Carabolyo, a name given by the Spaniards to the tract of comtry between the Atlantic Ocean and the Lake of Valencia, bounded on the west and south-west by the State of Yancuy and the Llanos de San Carlos and Calabozo.

In Colombia it occurs, although very rarely, in the extensive highlands of L'opitgitu. from the Rio Orejas to the Rio Hondo, in woods of a remarkably open and park-like asjeet. These woods consist chiefly of trees and shrubs of the following gremera: Mrimmmmin.

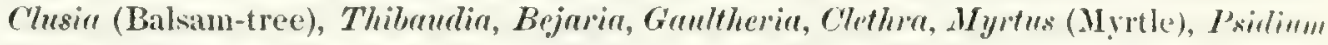
(Guava), Frezieru, Cinchonu, Inga (Soldier-wood), Ficus (Fig), Qunerns (Oah), A mmu (Custard-apple), Meriunin (Jamaica-rose), Leomlion, Micmin, etc. The trunks of the treen are covered with small lichens and a few mosses, and more rarely with ferms and Bromeliads. Orchids of the following genera are to be found in these woods: P/ommothollix,

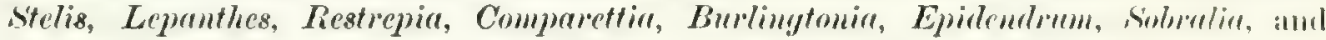

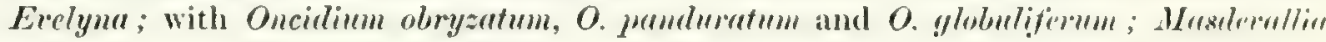
auropurpurea, M. maculata, M. Ephippim, M. muremle, and a few others.

The climate of this region is remarkable for dense fogs and heary rans, with frequent and very violent thunder-storms. During the winy season the nights are generally cleal. but towards daybreak dense fogs gather, and lie close above the woods, rescmbling. if observed from the higher regions of the Cordilleras, inmense loose masses of cotton wool. At about 8 o'elock these fogs begin to rise and to form large cumulus clouds, which, from 2 o'clock p.m. condense and fall in heavy showers, accompanied by severe thunder-storm, lasting as a rule until night. The dry season in Venezuela is from . Junuary to the cud of March, and in Cauca from July to September.

The annual mean temperature is between $18^{\circ}$ and $19^{\circ}$ Centigrade (about $6^{\circ}$ to $66^{\circ}$ Fahrenheit), and the extremes are $15^{\circ}$ and $25^{3}$ Centigrade (59 and $77^{3}$ Fuhrenheit).

F. C. LenMax: 




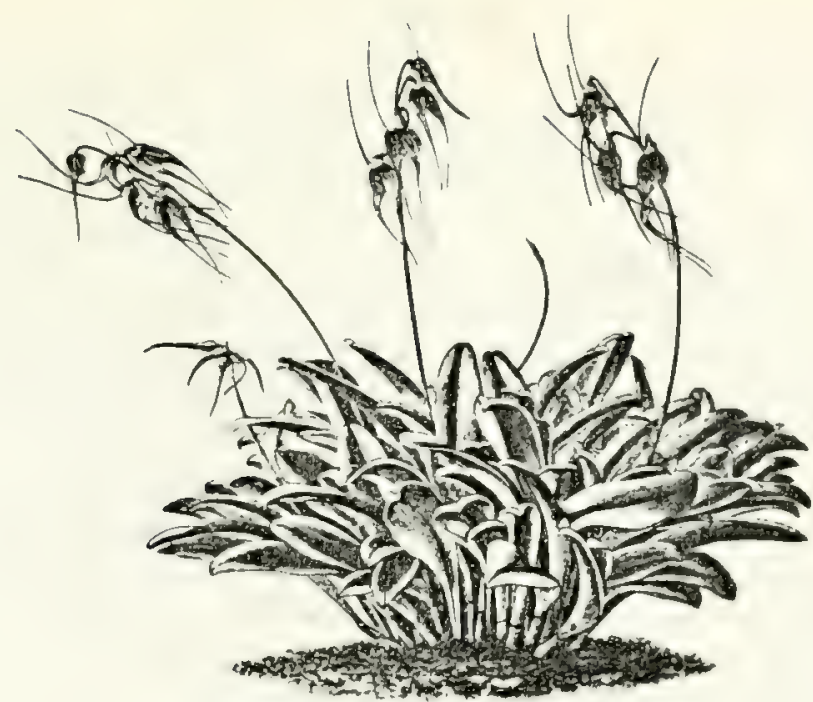

\section{MASDEVALLIA SCHLIMII Lind.}

Mantivilia Sculmu Lind. MSS. I.indl. Orch. I.ind. (1846), p. 5 ; Monplandia II. (1854), pp. 23 and 2ي3; Walp. Ann. VI. (1861), p. 194; Belg. Hort. XXIII. (1873), p. 360 ; Gard. Chron. 1883, pt. I. p. 532, fig. s0 ; Orchidophile (Godcfroy) 1883, p. 662; Bot. Mag. t. 6740 (1884) ; Die Natiirl. Pltanzenfam. (Engler und Prantl) pt. 23 (1888), p. 137, fig. 135; Veitch Manual Orch. pt. V. (1869), p.61.

I'nт. Steptrum=.Mestevallia Sceptrum Rehb. f. 13unplandia II. (1854), p. 283; Walp. Ann. VI. (1861), P. 194: Belet. Hort. XXIII. (1873), p. 360.

I'ar. polyantha=dJasdevalliu polyantha Lindl. Orch. Lind. (1846), p. 6; Bomplandia U. (1854), p. 283 ; HI. (1855), p. 69; Walp. Anu. VI. (1861), p. 193; Helge. Hort. XXIII. (1873), 1. 360.

Leaf 10 or 12 inches lone, ubovate, carinate, suex tridenticulate, very bright green, the principal nerves paler, marrowing below into a very pale green frooved petiole, sheathed at the base.

l'eluncle $1 \frac{1}{2}$ or 15 inches long, with two or three sheathing hracts, terete, ascending from within a sheath at the lase of the petiole, ricemose, producing six or eight flowers, each on an erect pedicel 1 or 1\$ inch longr. at intervals of 3 or $\frac{1}{2}$ inch, pade green dotted with dull red; Howering bracts about $\frac{1}{2}$ inch long, apiculate, suenthing below, brownish.

(Wary 1 inch lon: triangular, with six deep grooves, slightly winged, green.

Sejals: dorsal sepal united to the lateral sepals for 1 inch, forming a narrow tube, free portion triangular for albut $\frac{1}{1}$ inch, B̈-nerved, nerves carinte without, bright yellow, with minute reddish-brown spots, terminatine in a slender vellow tail about 2 inches long ; lateral sepals cohering for $\$$ inch, gibbous at the lase, 3-ncrved, ubosate for 3 inch, vellow, closely spotted with velvety, dull crimson spots, over which is a purplish lustre, tupering into slender vellow tails $1 \frac{1}{z}$ inch long.

letals + inch long, linear-oblong, acutely angled on both margins, with a Heshy keel on the anterior marcin. white, apex rery pale vellow.

Lip nearly 1 inch fong, whloug, curved, with two curved keels on the anterior portion, base tleshy, crooved. Whitibl, mottled witl transverse crimson spots, apex much retlexed, yellow spotted with crimson.

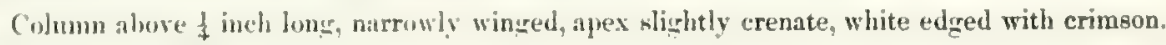

M

ASI)EVALLIA SCILLAII was discovered in 1843 by Louis Schlim, growing on trees at Valle, near Merida in Venezuela, at an elevation of 7,500 feet, and was first deseribed hy. Dr. Lindley in 1\%4, muder the name proposed for it by Linden in

Explanation of l'ate, drawn from a plant at Newbattle Abbey :

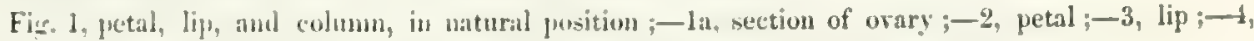
column :- 



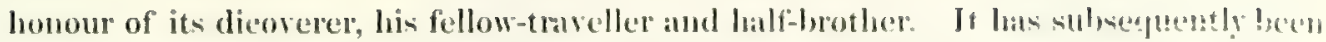
found in various localities of the Eastern Cordilleras of Colombia, and the first living plants were imported by Messis. Sander, of St. Allhans, in 1603.

Varieties of M. Schlimii have from time to time been found, and have in some instances received specific names. The variation seems to be chicfly in size and in the depth of colouring of the flowers, and may possibly be aceounted for by the great diflerence of elevation and climate, and the more or less exposed situations in which the plants grow, a difference quite sufticient-expecially in the case of the variety polynufluto cause even greater varion than has yet been met with.

The best-known variety, polyenthe, which has smaller and morecompactly armened flowers, was found by schlim at Ocaña, in Colombia, ahout the same date as Jl. shlimii. and was described by Dr. Lindley as a distinct species. The locality is eriven in the field-note of the collector, as follows: "An epiphyte at the entrance of the Parmo of" Portachueh, in the Province of Merida, at the height of 11 , ino feet, hetween bailatoren and La Grita; "Tune to September." The mean temperature of this elesated region is $4 i^{\circ}$ Filhrenheit.

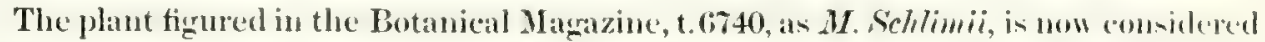
to be the variety molymthe. This specinen, taken from the collection of sir 'Trevon Lawrence, is preserved in the Royal Herbarim at Kew. The leaves are more rounded than those of $M$. Schlimi, and the flowers are smaller and less closely spotted, with the margins of the lateral sepals much refiexed.

Another probable variety, named as a distinct species $M$. Secptrom by l'rofexor Reicheubach, was collected by Schlim at La Baja and Pamplona, at an elevation of \&-9,000 feet, flowering in .January. It appeas to difler from $\boldsymbol{K}$. Sellimii only in having smaller and darker flowers. In Professor Reichenbachis description both of $2 M$. Serptimm and 1. polyenthe (Bomplandia II. p. 283), he mentions that the stem is angled or winged. a character not noticed by Dr. Lindley in his original description of $\nu$. polyunthu. No plant under the name of $M$. Sceptrm has ever been in cultivation, althongh dried specimens have occasionally been sent home under this name by rarious collectors. To the courtesy of Mr. F. Sander, of St. Albans, I am indelsted for an opportunity of examining one of these specimens, found at Ocana in 1s86, of which the chief chanacterintic agree in all respects with those of $\boldsymbol{M}$. Schlimii, the tails being perhaps a little thicker, flatter and shorter.

Consul Lehmann sends the following note:

The habitat of $\boldsymbol{M}$. Sclelimii is in Colombia and Venezuela, at an elevation of $1,80($ ) to 2,500 metres $(5,850$ to 8,125 feet). The region over which this species is distributed begins on the western slopes of the Eastern Cordilleras of Colombia near fiommono, continuing northward as far as the bifurcation of the Cordillera at the Pirmo de sinturban, and from thence north-eastward as far as Merida in Venezuch. In its halpit of growth it greatly resembles Masderellia Epliphinm, growing abundantly on trees in damp, but open and park-like woods, and limited to small localities, hage districtintervening without a trace of the plant to be seen.

The mean temperature of this region is between $14^{\prime}$ and $17^{2}$ Centignade (abont if to $\left(3^{\circ}\right.$ Falırenheit).

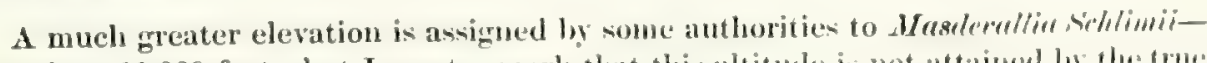
as much as 11,000 feet-but I must rematk that this altitude is not attained ly the true M. Schlimii, nor by any allied species or variety with wheh 1 an acepuanted, with the

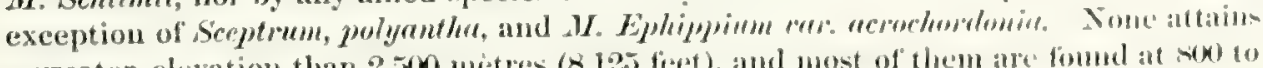
a greater elevation than 2,500 unetres $(8,125$ feet), and most of them atre foumd ant son 10

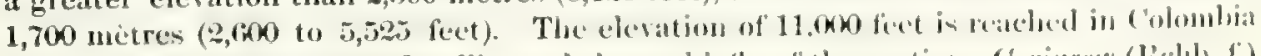

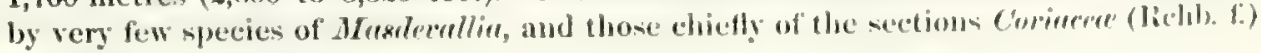
and Cuculletce (Relıb. fo). 




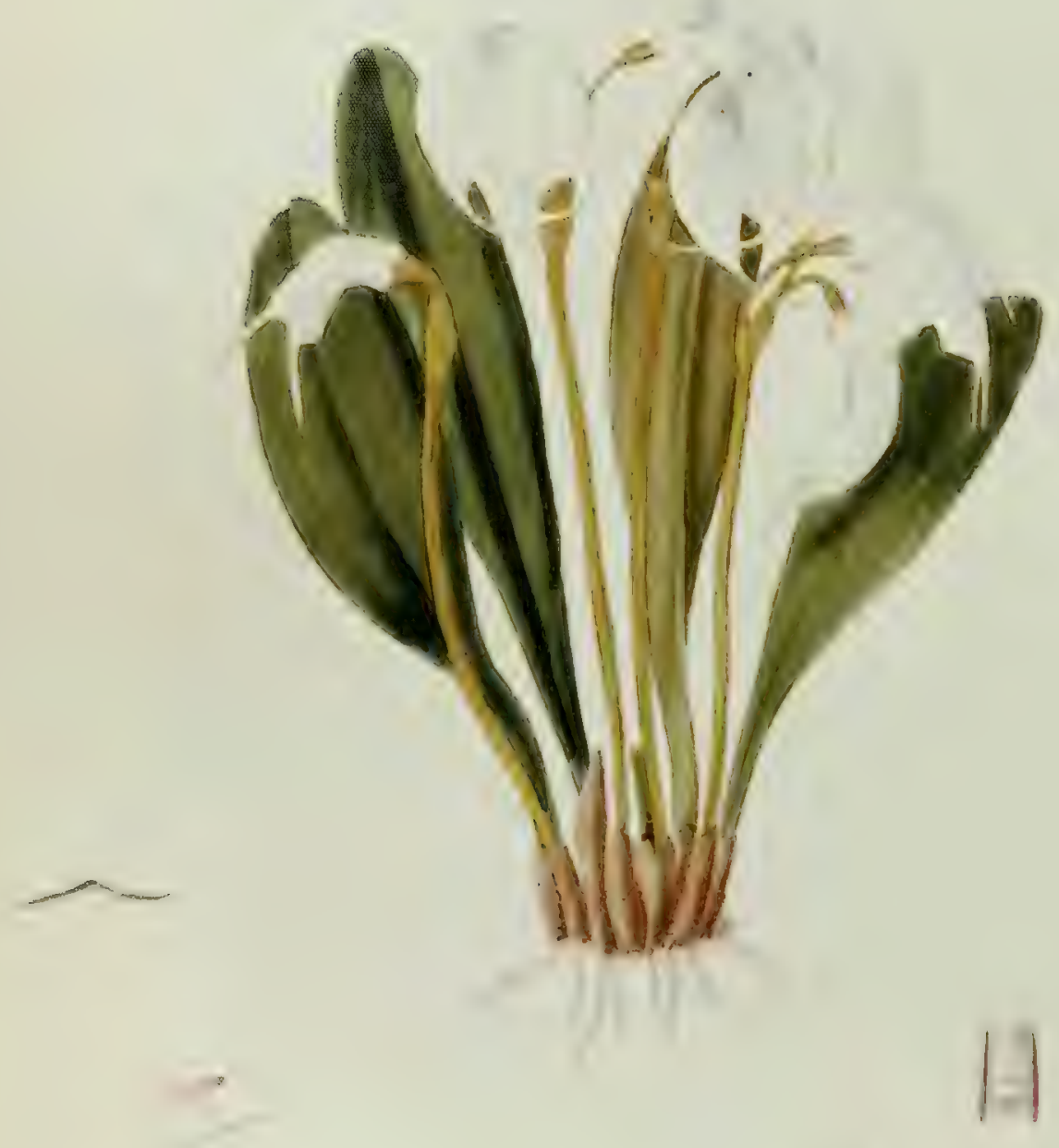




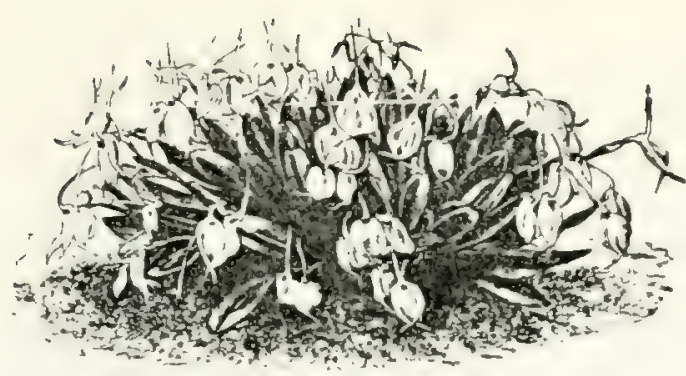

MASDEVALLIA TOVARENSIS Rchb. f.

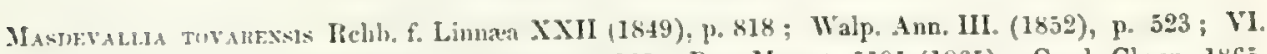
(1א61), p. 192; Bonplandia III. (1855/, p. 225 ; Bot. Mag. t. 5505 (1865) ; Gard. Chron. 1865, 1. 614. fig. B; $18 \% 1$, p. 1121, fig. 310, B, and p. 1486; 1874, pt. II., p. $715 ; 1881$, pt. II., p. 409, fie. 1;: Fl. and Pomol. 1873, p. 169, fig. 5 ; IBelg. Hort. XXIII. (1873), p. 360; Illustr. Hort. XXVI. (1879), 1, 169, t. 363 ; De l'uydt, Les Orch. (1880), p. 287, pl. XXIV.

M. condidu Klotzsch et Karst. Bonplandia II. (1854), p. 23; Walp. Ann. VI. (1861), p. 192; Gard. Chron. [87], p. 1121; Belg. Hort. XXIII. (1873), p. 355.

Lat' about 6 inches long, oblong-nvate, tridenticulate, narrowing below into a grooved petiole sbeathed at the lase, dark green.

l'eduncle 5 or 6 inches lung, sharply angled, angles two to five, unany-flowered, ascending from within "s shentl at the base of the petiole, bright green; bracts ahout $\frac{1}{2}$ inch long, sheathing, apiculate, bright green.

():ary nearly 1 inch long, with three acute angles, bright pale green.

Sepals: iloral sepal united to the lateral mepals for about 1 inch, forming a narrow tube, free portion trimgular, 3-served, tapering into a slender tail shout 13 inch long; lateral sepals colsering for nearly 1 incl. trec portions hroadly oval, 3-nerved, terminating in slender tiils about s inch long; all pure white, with pale vellowisl-green tails.

l'etals $f$ inch lons, lincar, apriculate, angled on the anterior margin, white.

Lip ahme 1 inch long, slightly arrowed at the base, united to the foot of the column by a flexible hinge'. prudurate, with two bongitulinal heels. apex retiexed, white.

('olum saredy 1 inch lone, narrowly winged, alvex denticulate, white, tinged and winged witl। purple-crimsun.

THIs -yecies wats discovered in 1422 by Linden, at an elevation of 2,000 metres $(6,500$

feet). near Tovar. a small (ferman colong in Venezuela, and named-in manuscript

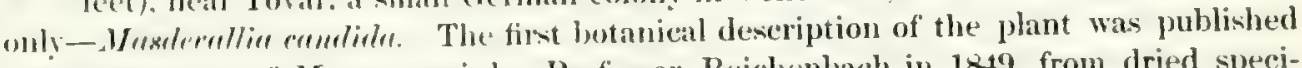

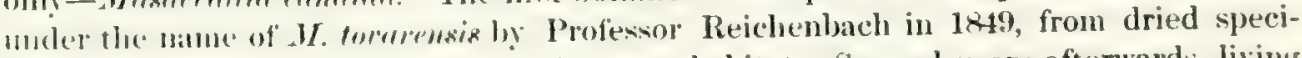

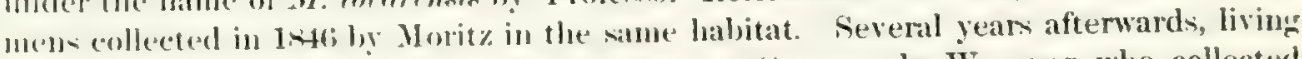
plant- under the name of $2 /$. roudidn were sent to Germany by Wagener, who collected them neall (atracas at all elevation of 6,000 feet. One of these plants, sold to the late

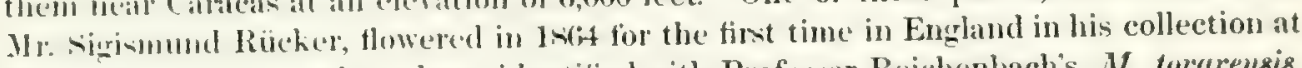
Went Hill. Wandworth, and was identitied with Profesion Reichenbach"s M. Morurensis.

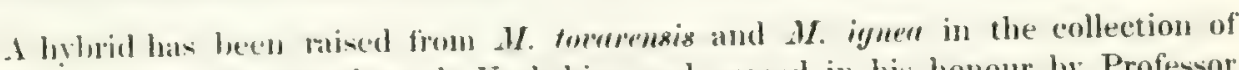
Caphanin Hinckio, of Brechenbrough, Yorkthire, and named in his honour by Professor

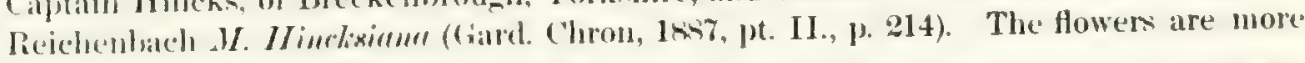

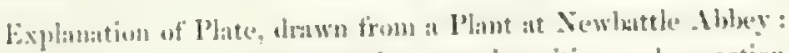

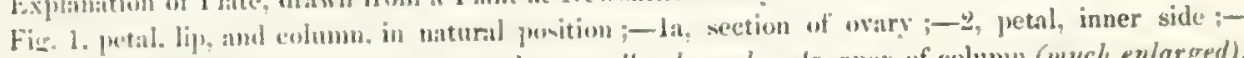

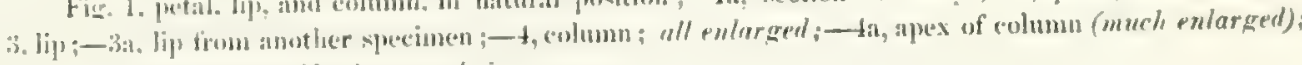

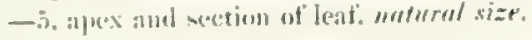



slender than those of $M$. formensis, and ate of a delicitte golden-yellow colont. It is curious to note that the terete fower-stems usually produce more than one flower, the plant in this respect resembling the many-flowered 12 . formermas, the pollen-plant $M$. ignere having solitary flowers.

Two other hybrids have been mised, both by Messis. Sander, of st. Allaths: M. Mensuresinue (Gard. Chron. 1890, pt. II., p. 3759), white, bordered and nersed with

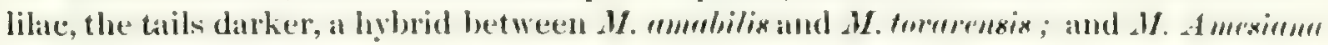
(Gard. Chrom. 1891, pt. I. p. 335, and pt. II. p. 197), apricot colour-naised from $1 /$. Teitchirun and M. formernsis.

Comsul Lehmann sends the following note:

Up to this date, Magderollon formensig appeas to have been found only in the suall colony of Tovar, near Caracas in Venezuela, at $\mathrm{an}$ elevation of 1,500 to 1, 400 metres $(4,875$ to 5,850 feet). It grows on trees in open, park-like woods, under exactly the sams. conditions as $M$. muculata.

F. C. Leminas. 



\section{SECIION IX.}

\section{RACEMOSA.}

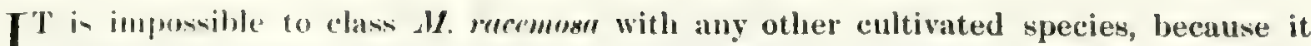
differs so essentially from them all. By the advice of Consul Lehmann I place in the sime section M. Edumbli, which, although very much smaller, has atso creeping rhizones, producing leaves at intervals, and bearing two or three scarlet flowers upon one stem.

1 species figured:

Masdevallia racemosa Lindl.

Not in enltivation:

.1. Edhurdi Jichb. t: Gurd. C'hron. 1880, pt. II., p. 798. 





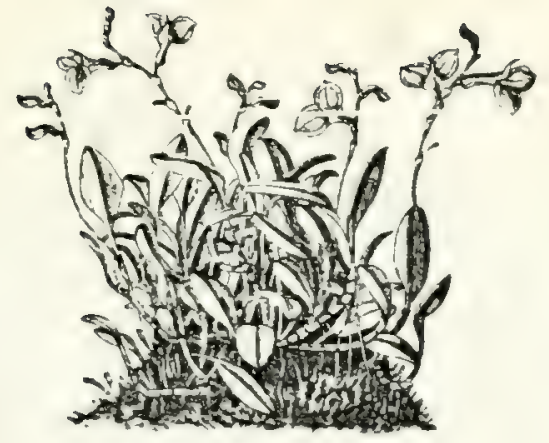

\section{MASDEVALLIA RACEMIOSA Lindl.}

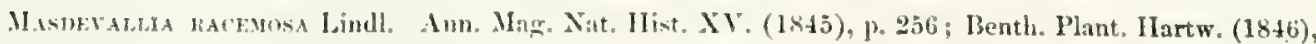

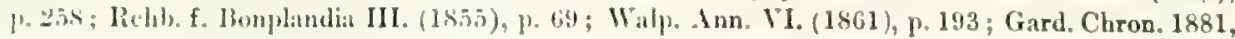

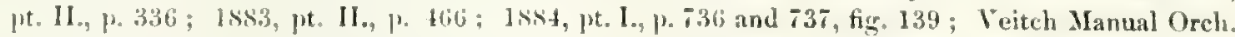
1t. I. $(1 \times 89)$, 1. 58.

lonf 4 ur 5 inclues long and ahout 3 inch wide, oblong-ovate, apex tridenticulate, margins recurved, dull revinl-green, narrowing below into a slender grooved petiole, sheathed at the base and produced froul a crepping rhizonte at intervals of 1 or $1 \frac{1}{2}$ inch.

Pealuncle s to 15 binclies long, erect, slender, terete, dull reddish-green, many-Howered, the flowers developing in wecession, two or three only being expanded at the same time, the pedicel of each baving a sheathing brown membranous bract at the bane, 3 incli long. embracing the peduncle and the pedicel.

()ary nearly 4 inch long, with six rumed angles, bright crimson.

Sepals: dorsil sepal united to the lateral sepals for about anch, forming a straight narrow tube, free purtion wate-trintular for $\frac{1}{1}$ inch, 3-nerved, termintiner in a tail about $\frac{1}{4}$ inch long; lateral sepals colsering for 1 inch or a little more, broadly cordate, 3-nerved, terminating in a small blunt point; all the sefuls orange-scarlet with the nerves and margias vermilion, tube yellowish-scarlet.

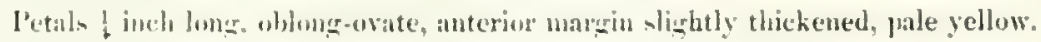

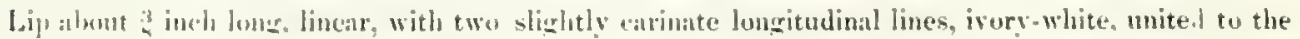
fent of the colum lw a Hexilse hinese

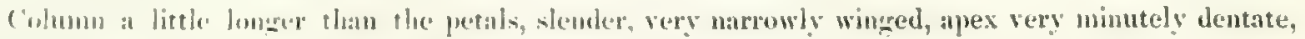
palfe vellow and pink. with a fow suall pink spots. and one deej purple spot on each side of the foot.

$\mathrm{M}$

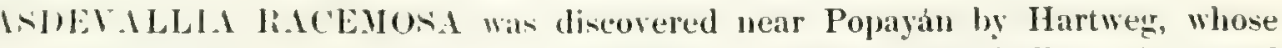
dried specimens were named and deseribed in 1845 by Dr. Lindley. A second dencriptions. al-o written hy I)r. Lindley, appeared in May, 1846, in Bentham's " Plantas

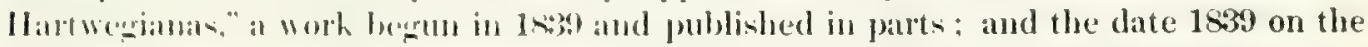
title-paige has canced the erroneous impression that the plant was first described in that rear: Hartwey states that he discovered the plant in woods at Pitayo and also on the Hopes of Purace near Popayin, at an elevation of 10,000 to 14,500 feet. It was subsefuently foumd by other eolleceron in the same part of the Central Cordillen of Popayan. So living plants, however, were sent to this country until 1883, when Messrs. Shuttleworth and cirder vecereded in innorting a small number. The difficultien of importing

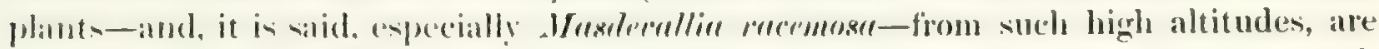
numerous. owing chicfly to the great difference of temperature between the cool fresh

Explanation of l'late, drawn from at plant at Xewlattle dbbeg:

Fig. 1. petal. lip) and colum, in natural ponition;-1a, section of wary ;-2, petal, imner side ;-

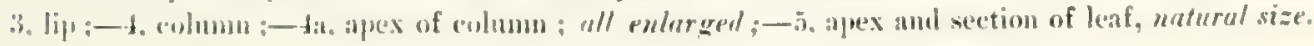





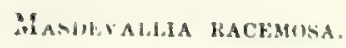

air of their native habitat and the hot steaming atmosphere of the lowlands near the coast or the navigable rivers. Delays in the tropical heat of varous ports have aloo to be encountered-four days at Colon, two days at . Tamaica, etc-before the ewelve days voyage across the Atlantic is even beerum. Pathetic accounts are given by collectors of the injury sustained by their treasures fermenting rapidly in the intense beat of the ship's hold, daily examination revealing the damage done, and necessitating the lhrowing overboard of rare plants which would have realised a fortune if brought alive to Europe.

The first drawing of $M$. racemora was one by Consul Lehmanu, published in th. Gardeners' Chronicle in 1884. He found his specimens growing on the frround, rarely on trees, in moderately thick woods on the western slopes of the Paramo de Moms, de las: Delicias, and del Guanaca, at an elevation of 2,900 to 3,800 metres (about 9,416-12,350) feet).

The mistaken idea that ench flower-stem of $\boldsymbol{M}$. racemosn produces numcrous fowers expanded at the same time, seems to have originated in the fact that some dried specimens with ten to fourteen flowers carefully arranged upon the dead stalks were exhibited at the first sale of living planto in 1883 . The number of flowers developed at the silme. time never exceeds four and mrely exceeds two; among many specimens, both dried and living, I have never seen a stem with more than two open flowers. In Consul Lehmann: descriptions of wild specimens collected hy him, he mentions that the flowers appear in succession, sometimes as many as eightecn upon one stem.

The structure of $\boldsymbol{M}$. racemosa, and the curious growth of the leaves at intervak along the creeping rhizomes, distinguish it so clearly from all other known species that it cannot be classed in any of the sections originated by Professor Reichenbach. 


\section{SECTION $\mathrm{X}$.}

\section{IIIICHENBACHIANAE.}

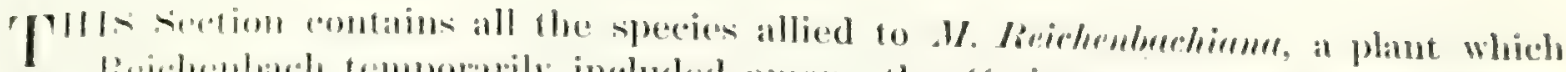

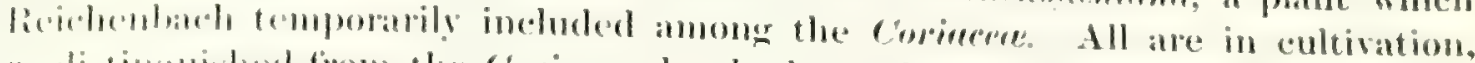

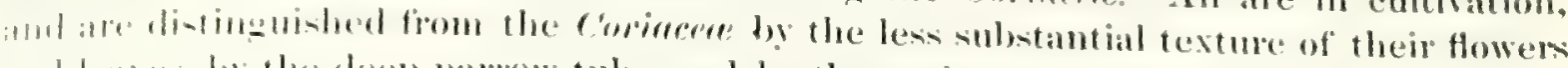

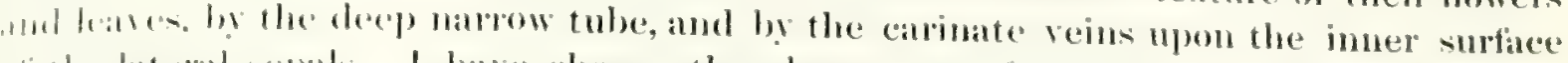
ul the lateral sepals. I hare chosen the above name for this section, partly becanse

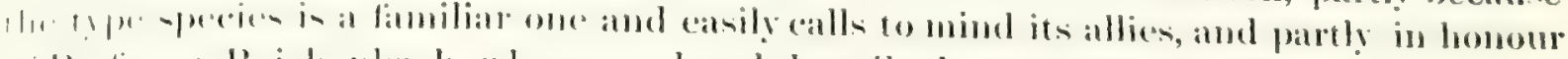

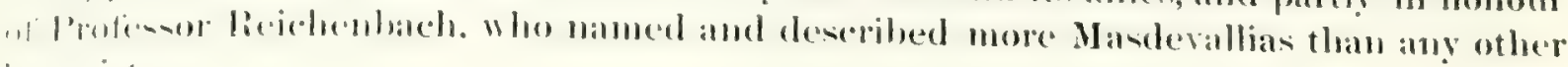
lustanise.

7 species figured :

Mardevallia (alura Rechb) fo

demissa Rehlof:

finlvescens Rolfe.

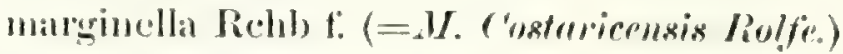

Reichenbachima Endres.

Rolfeana Krinzl.

Seluroederiana hort. Sander. 




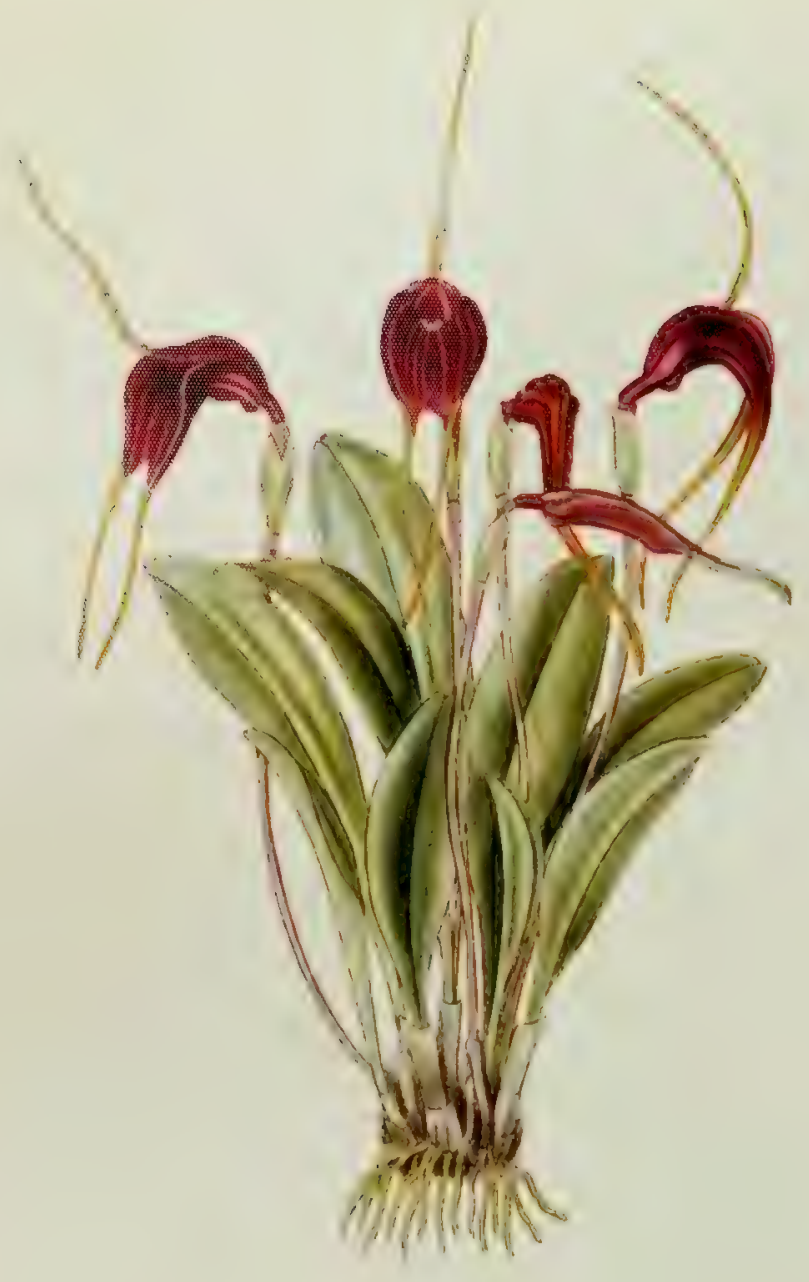

4

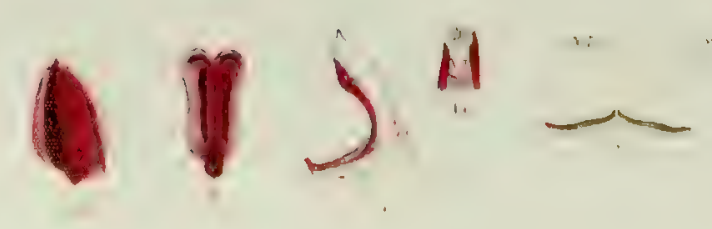




\section{MASDEVALIİa C̃ÁLURA Rchb. f.}

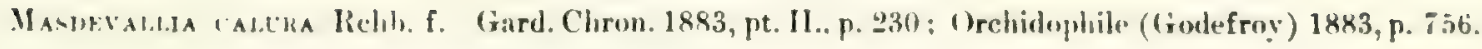

La:af about 4 inches lomg, whlong-lanceolate, carinate at the back, apex tridenticulate, margins slightly recurred. bright areen, narrowing below into a slender grooved petiole, wheathed at the base.

l'edumele a little longer than the leaves, terete, with two or three shenthing hracts, ascending from the base of the petiole, clull real: Howering bract about $\frac{1}{2}$ inch long, apiculate, sheathing below, pale treen.

Wary a inch Jomg, with three large and three small rounded angles, shining, dark crimson.

Sipals: dorsal sepal united to the latemal sepals for about 5 inch, forming a narrow tube, gibbous lscluw, fiee purtion very short, triangular-ovate, 3-nerved, tapering into a slemder tail nearly $\mathbf{2}$ inches

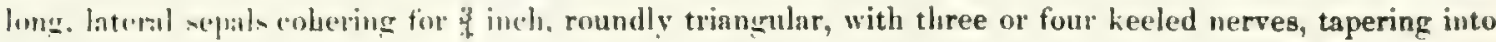
sender Hattemed tails nearly I! inch long; all dark shining crimson, tails yellow, tipped with orange, and greenish at the back.

P'etals about fo inch lomer, Henhy, oval, with a triangular apex, and a small angle a little below, anterior margin roumled and much thichened, rich crimson, with a white apex and margin.

Lip scarcely as long as the petals, fleshy, united to the foot of the column by a flexible hinge, panluratc, with two longitudinal keels, apex rounded and reflexed, dark crimson.

Column expalling the petals, white, bruadly edged with crimson, foot rich crimson.

MASDEVALLIA CALURA was discovered and introduced into cultivation by Consul Lelımann, who sent plants to Messis. Sander in 1882. It grows with $\boldsymbol{M}$. Jirichenbuchimur on the western slopes of the Vulcan Irazu, near San Isidro, in Costa Rica, at an elevation of $1 .(600$ to 2,000 metres $(5,200$ to 6,500 feet.)

Lixplamation of Plate drawn from a plant at Newbattle Abhey:

Fig. 1. peral. lip. and columm, in natural position;-1a, section of wrary ; -2 , petal, inner side ;3, lip :-4. colıun :-4a, apex of colımn; all enlarged;-5, apex and section of leaf, natural size. 





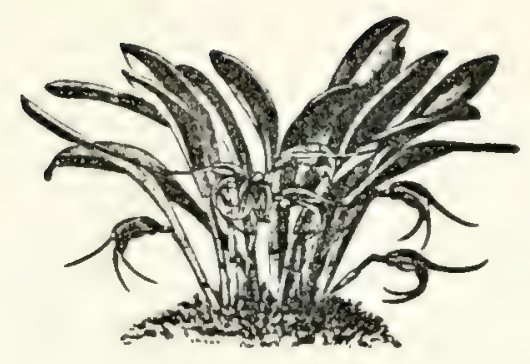

\section{MASDEVALLIA IEMISSA Rehb. f.}

Masmivatia nkmissa Relıh.f. Gard. Chron. 185T, pt. II., p. 9 ; (trchidophile (Godefrov) 1888, p. 168; Veitch Manual Oreh. pt. V. (1889), p. 39.

Lenf 5 or 6 inches lonw, oblong-spatluate, carinate at the back, leathery, apex tridenticulate, bright green. narrowing below into " pale green grooved petiole, sheathed at the base.

Peduncle, including pedicel, ahout 2 inches long, terete, ascending from within the sheath at the base of the petiole, with two sheathing bracts, pale green; flowering bract about 3 inch long, oblong-orate, apiculate, sheathing below, pale brownish green.

Orary 1 inch long, with six grooves, shining green.

Sepals: dorsal sepal united to the lateral sepals for nearly $\frac{3}{4}$ inch, forning a narrow curved tube, free portion very short, triangular. 3-nerved, terminating in slender tail about 1 inch long, bright yellow shaded with chestnut-hrown: latersl sepals cohering for inch, triangular-ovate. 3-nerved, terminating in slender recurved tails nearly 3 inch homg, l,right chestunt-brown witl orange veins, all the tails orange, greenish at the bact.

Potal, abunt f incl, lome, ohlong, with a rounded angle on the anterior margin, thick and fleshy, dull crimsm-purple. paler at the margin.

L.ip a litrle longer than the petals, ohlong-jandurate, with two longitudinal angled keels, hase thick, grewerl. united to the curved foot of the column by a flexible hinge, apex recurred, dull crimson-brown, the keels paler.

(', (umm ne:arly an fonc as the petals. curved, very narrowly winged, white, foot crimson, apex rery minutely erenate.

\section{TMP(ORTEI) from the mountains of Costa Rica by Messrs. Shuttleworth and Carder, of ('lipham, ahout the year 1886, with no record of its exact habitat.}

Explanation of Plate, drawn from a plant at Newbattle Abbey:

Fig. 1, petal, lip, and column, in natural position ; - la, section of orary ; - 2, petal, inner side ;3. lip:-4. column :- - tu. spex of column; all en/arged; -5 , npex and rection of lesf, natural size. 




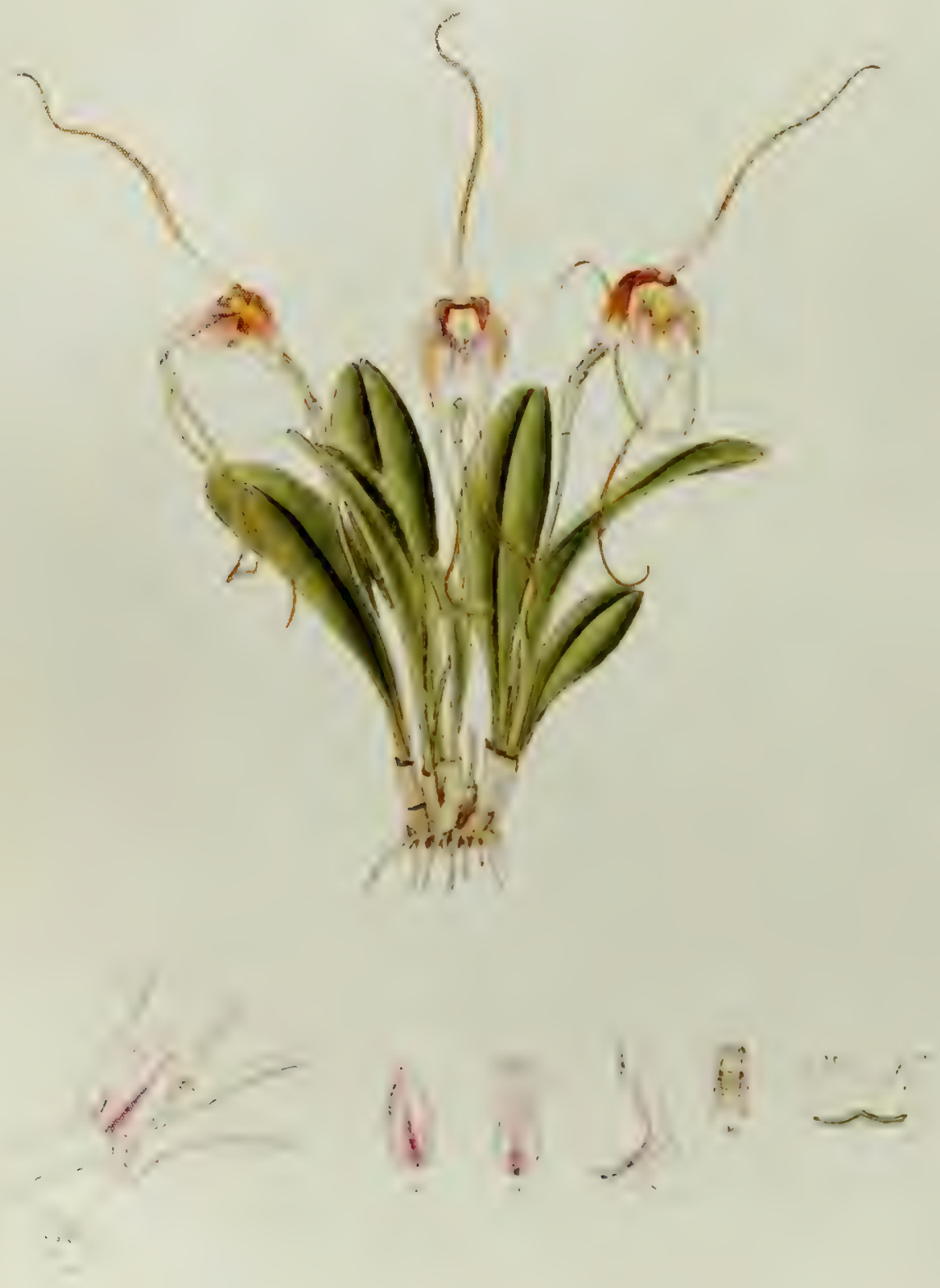




\section{MASDEVALLIA FULVESCENS Rolfe.}

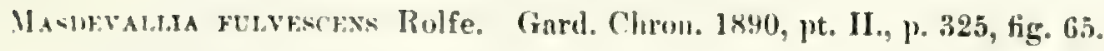

L.eaf about 4 inches long. oblong-lanceolote, carinate at the back, apex tridenticulate, narrowing below into a slender grooved petiole, shenthed at the base, bright green.

Peduncle 3 inches long, terete, slender, erect from within the sheath at the base of the petiole, pale groen: bact ! inch lomg, mombranous. wate, apiculate, sheathing below, with a minute rudimentary bud within at the base, pale green.

Gary I inch long, with six rounded angles, pale green.

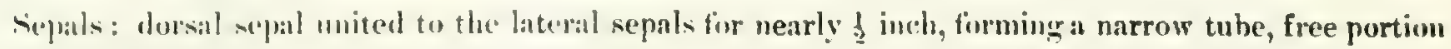
hroad! trimerular for nealy | inch, cucullate, 3-nerved, dull orange-yellow shaded with reddisls-crimson, reminating in al slender. Waved. Hattened tail $2 !$ or 3 inches long, bright orange. pale greenish-yellow at the hase : lateral sepals cohering for about 1 inch, oblong-triangular, with three prominent nerves. the spaces hetwern hollowed inwards, white, shaded with pale rose-pink and rellow, tapering into slender, waved. Hattened tails about 2 inches Jong, bright orange, pale greenish-yellow at the base.

Petaks scarcely $\frac{1}{4}$ inch long. ublong, very thick and fleshy, margins waved, anterior margin much thickened, pale pink, with a few small rose-pink spots and a darker central stripe.

Jip a little longer than the petals. Heshy at the base and united by a hinge to the foot of the column, oblong, with two small hongitndinal hech near the centre, apex recurved, very pale pink, with a darker stripe and a few spots near the apex.

('ulum it little shorter than the petals, narrowly winged, apex denticulate, white, with rose-pink spots.

MASDEVAlala FULVESCENS was imported from Colombia, iu 1890, by Messrs. F. Horsman and Co., of Colchester, and there is no further record of its habitat. It is closely allied to, if not identical witl, $M$. Schroederiann, which is, however, so much more heautiful that 1 have figured it in a sepante Plate, treating it-until some more competent botanist shall decide the question-as a distinct species.

Lixplanation of l'bute, drawn from a plant at Newbattle Abbey :

Figr. 1. pretal. lip. anul colum, in natuml position;-1n, section of ovary ;-2, petal, inner side ;3. lip :-4. culumn :- 4iı, apex uf column; all enlarged; -5 , spex and section of leaf, natural size. 





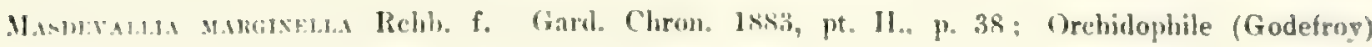
$1,8,3.1 \% .095$.

1\%. Cinsturivensis liolfe, (iard. Chrom. $18 ! 10$, pt. II., p. 183.

I.eaf anent + inches lone, ohovate-spathulate, tridenticulate, narowing below into a slender grooved petiole. westhed at the base. bright green.

ledumele 3 or 1 inches long, terete, slender, attenute helow, 1 or 2 -Howered, ascending from the

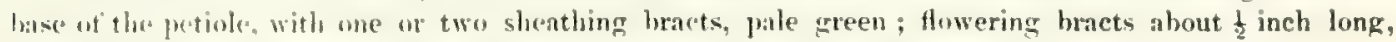

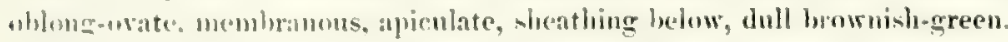

Worr 1 imeh lome, with six rounded amgles, shining green.

Sholal: : dolsit -cpall united to the biteml sepals for 1 inch, forming a narrow conpressed tube,

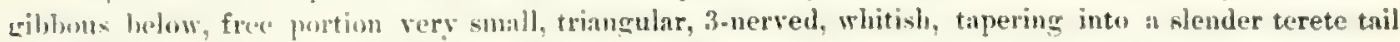
alwut 1! inch long, ercen at the base and back, brilliant orange-scarlet in the frout; lateral sepals

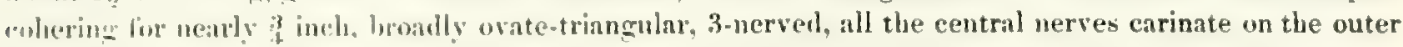
mfince. whish, with a short central streat of pale vellow, and terminating in slender terete tails about 1) inch lons. pille green at the lase, front oranguellow, nerres green.

l'etals I inch long, oblongeosate, thichened on the anterior margin, with a suall rounded projection mi the opposite side. white.

I.ip a little Inomes than the petals, wide at the base and united by a hinge to the curved foot of the colmm. marrins renred. with wo angled longitudinal kexk near the centre, white, apex much recurved, pink and vellow. marems dentate.

Colnum copulling the petals, winged, apex acutely denticulate, white, foot pale yellow.

MASDEVALLIA MAR(TINELLA was imported by Messis. Sander, of St. Albans, about the rear 1882. from the Momitains of Costa Rica. It grows with $\boldsymbol{M}$. lifichembrhimm and 11 . colmor, to both of which plants it is closely allied. In $1890 \mathrm{it}$ Was anilin described, as a new species, by Mr. R. A. Rolfe, of the Royal Herbarium, Kew, under the mume M. ('oxtmricensis, from specimens in the collection of Mr. Sydney Courtauld.

In separating .1. morginellu fiom the ('orincee, with which Reichenbach classed it, I :m not diffiring altogether from his opinion, for, in his account of $M$. Reichenbachiam, (iard. ('hon. 15\%. pt. I1., p. 25., he say's of that species: "This interesting Masdevallia one might introduce as helonging to the Coriacese group, provided one does not think it betrer to malic of it a new yronp, on accomnt of its fumel-shaped tube, narrowed at the hase, rery slender tails, and thin texture."

There (an be no doubt of the atfinity between $\boldsymbol{M}$. marginelle and $\boldsymbol{M}$. Reichenbachiana, and they must therefore be classed together, with others also closely allied, such as

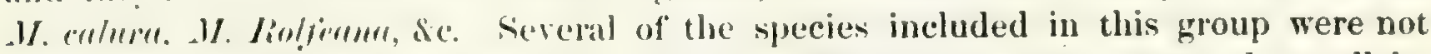
introduced mutil after Reichenbach's deith, in 1889, and had he known them all he would probably have classed them in " new section. His words, quoted above, well describe the differences hetween flower of this section and those of the Coriacere. The leares differ chicfly in being more slender in the petiole, less rigid, and wider in proportion to their length. These chancteristics will be well seen by comparing the leaves of $\boldsymbol{M}$. lommoglossa with those of $\boldsymbol{M}$. marginella.

\section{Explanation of l'late:}

Fig. 1, petal, lip, and column, in natural position; - la, section of orary ; - 2, petal, inner side ;-

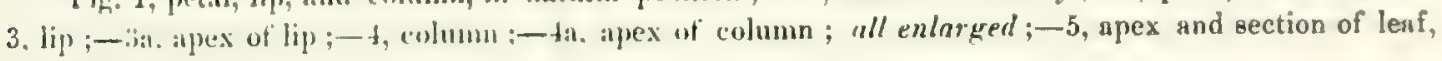
notural size. 




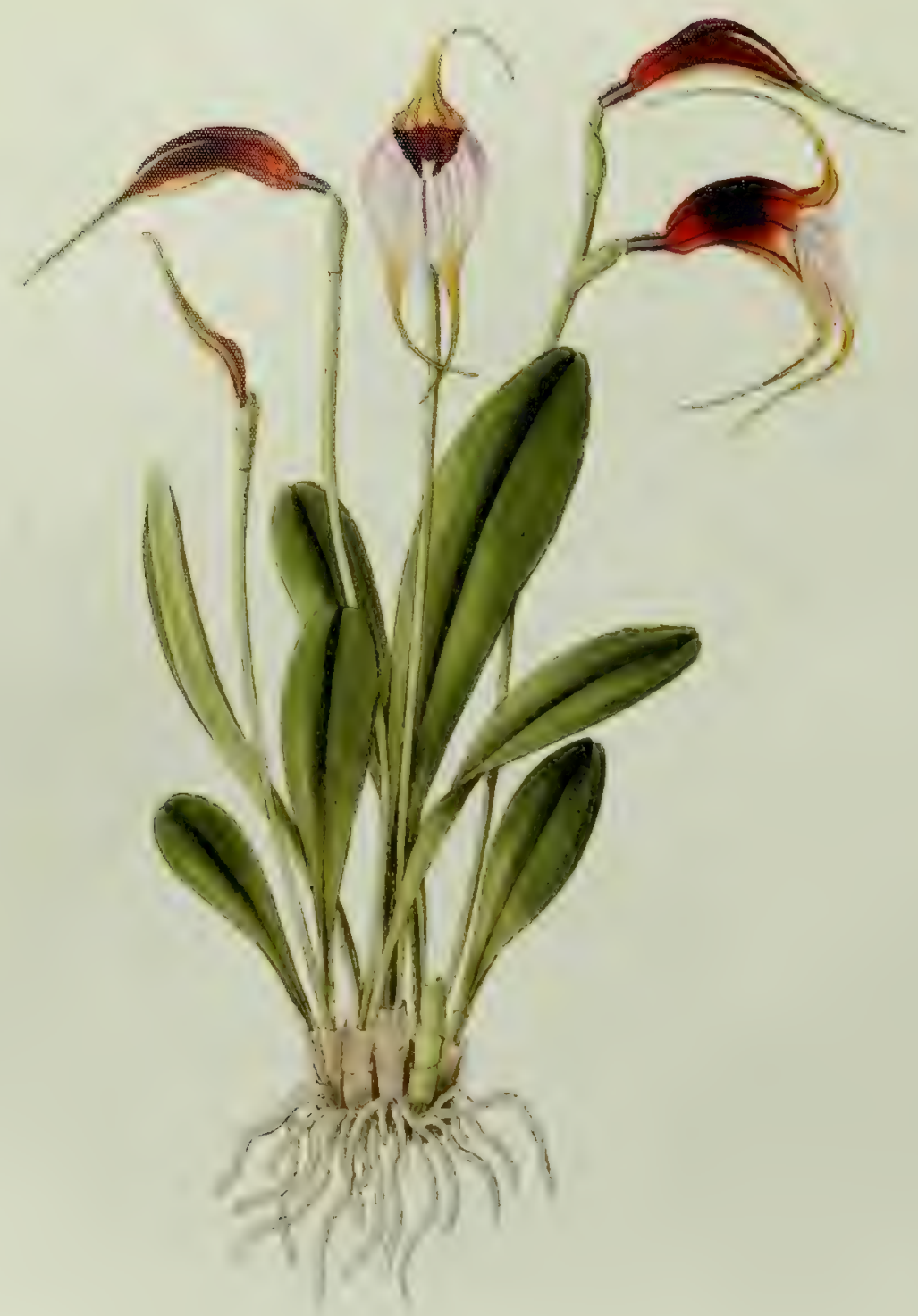




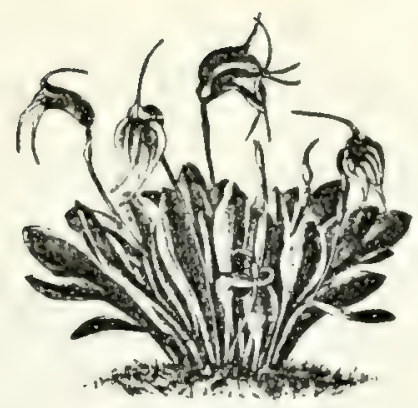

\section{MASDEVALLIA REICHENBACHLANA Endres.}

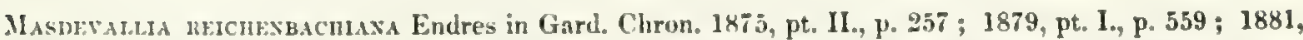
pt. II. p. 336; 1883. pt. II., p. 360 (var. aurautinca Rehb. f.); Orchidophile (Godefroy), vol. I. (1881), p. 97 ; Veitch Manual Orch. pt. V. (18s9), 1. 60 ; Lindenia rol. VI. (1890), p. 23, pl. CCL.

.1. Normami hort., syn. fide Rehb. fُ. Gard. Chron. 1881, pt. II., p. 230.

Leaf 4 or 5 inches long, 3 or 1 inch wide, ohlanceolate, carinate, tridenticulate, narrowing below into a grooved petiole, sheathed at the base, bright green, the two principal aerves paler.

I'eduncle 6 or $\bar{i}$ inches long, terete, ascending from within a sheath st the base of the petiole, 1 to 3. flowered, bright green; bract about $\frac{1}{2}$ inch long, shenthing below, orate-apiculate above, bright green.

(Nary about $\frac{1}{4}$ inch long, with six rounded angles, dark brown or greenish.

Sepals : dorsal sepal united to the lateral sepals for about 1 inch, forming a wide tube, free portion triangnlar for about $\frac{Z}{8}$ inch, 3 -nerved, inner kurface pale yellow with red nerves, outer surface rich dark red or claret-crimson, almost scarlet at the base, tapering into $\Omega$ slender recurved tail about 2 inches long, greenish-yellow; lateral sepals cohering for $1 \frac{1}{4}$ inch, triangular-ovate, 3 -nerved, nerves bifurcating and strongly carinate, inner surface pale lemon-yellow or pearly pink, tinged with red near the outer margin, outer surface pale yellow, crimson, and red, tails $1 \frac{1}{2}$ inch long, slender, pale green.

Petals $\frac{1}{\downarrow}$ inch long, oblong-ovate, anterior margin much thickened, ivory-white.

Lij) $\neq$ inch long, oblong-pandurate, with two short longitudinal keels, ivory-white, apex narrow, recurved, pale yellow.

Column f inch long, winged, ivory-white, apex denticulate, pale yellow.

$\mathrm{M}^{\mathrm{A}}$

ASI)EVALLIA REICHENBACHIANA was discovered in 1873 in the mountains of Costa Rica, by Endres, who named it in honour of Professor Reichenbach. Imported plants first flowered at Little Stanmore, Middlesex, in 1875, in the collection of the Rer. .T. B. Nomnan, who, under the impression that the plant was a new species, named it $M$. Normomni.

The flowers vary greatly in colour, the outer surface being sometimes of so dark a shade of red as to appeat almost black, and sometimes of every shade of crimson or purplisli-red. The inner surface of the flowers is of an extremely delicate shade of pearly pink, the effect of the deep colour of the outer surface seen through the semi-transparent tissues of the sepals. The flowers last a long time in perfection, a second and even a third flower expauding before the first fades.

In the variety named aurmtincr by Professor Reichenbach, the dark red is replaced by rich orange.

Explanation of Plate, drawn from a Plant at Newhattle Abbey :

Fig. 1, petal, lip, and column, in natural position ; - 1a, section of orary ; - 2, petal, inner side ;3 , lip :-4, column; $-4 a$, apex of colums; all enlarged; -5 , apes and section of leaf; natural size. 

Of the habitat of this species Consul Lehmam gives more detailed information than any hitherto published :

M. Reichenbuchiana is distributed over the Central Cordillera of Costa Rica, between the Vulcan de Barba and the Pico Blanco, at an elevation of 1,600 to 2,200 ) mitres (5, $2(x)$ to 7,150 feet). It grows on trees in dense and damp woods, in an avelayge smmment temperature of $17^{\circ}$ to $19^{\circ}$ Centigrade (about $132^{\circ}$ to $66^{\circ}$ Fahrenheit), and an arelane winter temperature of $15^{\circ} .5$ to $17^{\circ} .5$ Centigrade (about $60^{\circ}$ to (in Fahrenheit).

I first observed it in 1878, on the western slopes of the Vulcan Frazu near sim Isidro also on the mountain range between Cartago and San Pedro; on the mountains between Desamparados and San Cristolsal ; and in the Montaña Dota. From these localities I sent a few living plants to Messis. Hugh Low \& Co., of Clapton. The tirst lanpe consignment of living plants was sent by me to Messrs. Sander, of St. Allans, in 1.x.? with plants of $M$. calure and $M$. erythrochete, from the same localities.

F. C. Lenmax. 



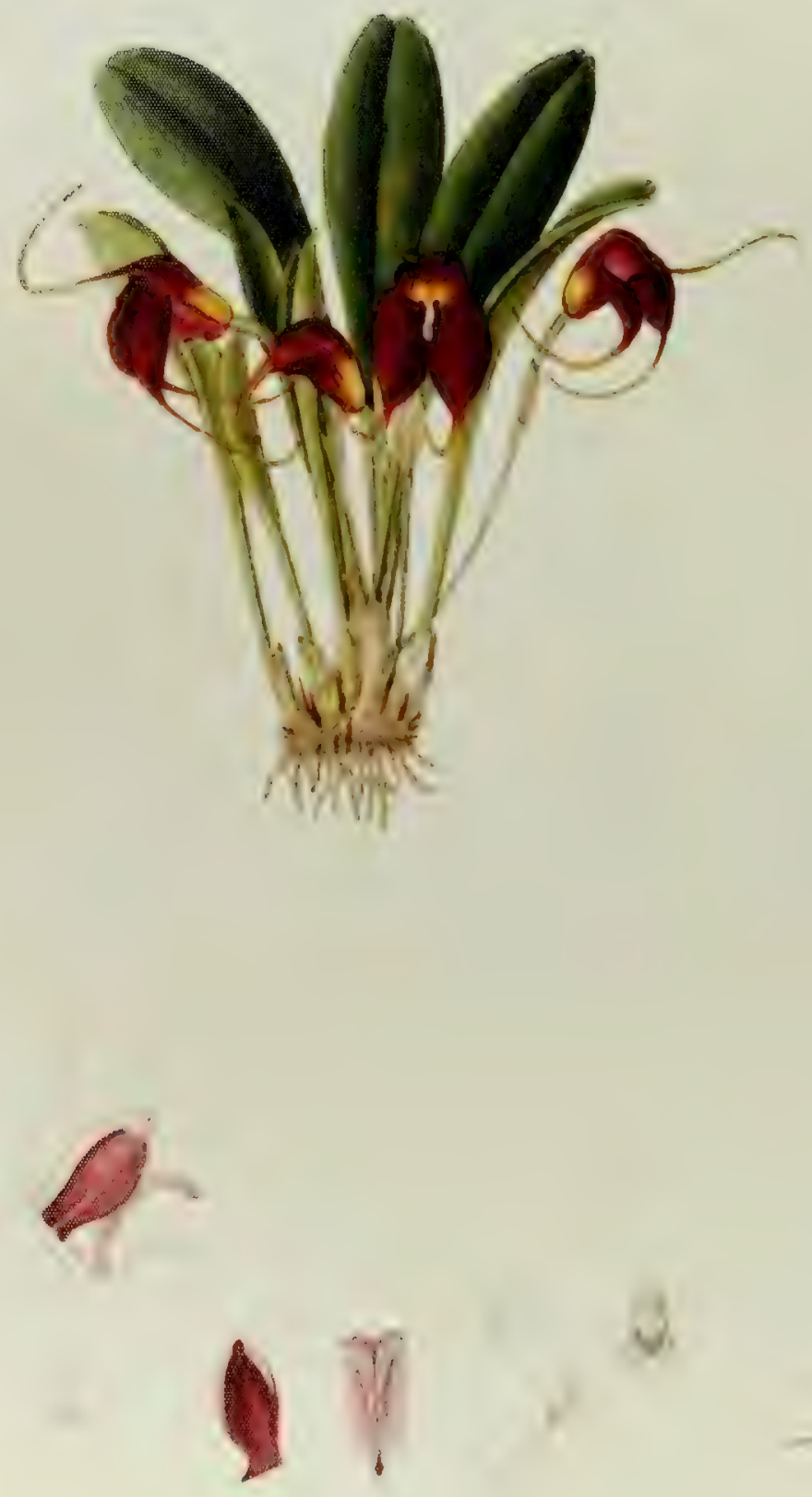


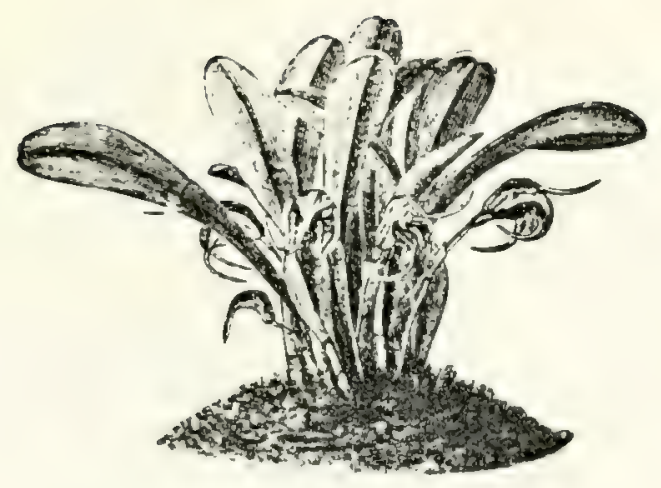

\section{MASDEVALLIA ROIFEANA Kräz.}

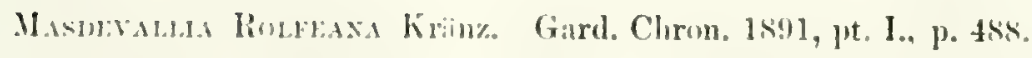

Leat" about is inches long and iz inch wide, obovate, thick and fleshy, carinate at the back, apex whtuse? tridenticulate. dark shining green, narrowing below into a slender grooved pale green petiole, sheathed at the hase.

Peduncle, including pedicel, ahout 3 inches long, terete, slender, ascending from witbin a shenth at the base of the fetiole, lrielit sreen; bract $\frac{1}{2}$ incls loms, wate, apiculate. brownish, sheathing below, with a minute mdinentary bud within at the base.

(Wary ! inch lone. with six rounded anerles, pale green.

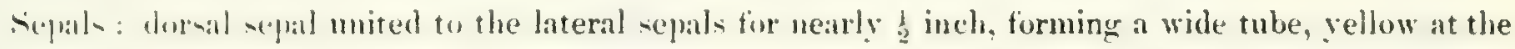

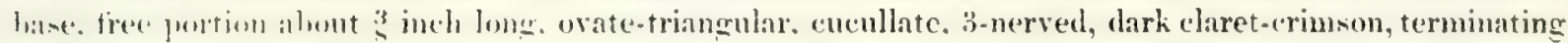

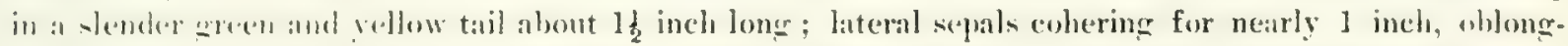

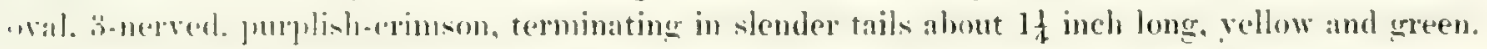

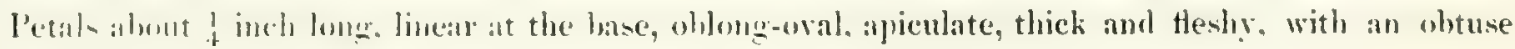
kees on the anterion matrin. dark purplish-crimson, galer towards the apex.

Lij, a litgle bonger than the petals. oblong, apiculate, Heshy at the base and united to the curved foot uf the volum hy a flexihle hinere. witls two lateral lemeitudinal keels, pinkish, with brighter spots, apex tleshy. recourvod. crimsom.

Colmm at little lomer than the petals, narrowly winged, white, apex denticulate.

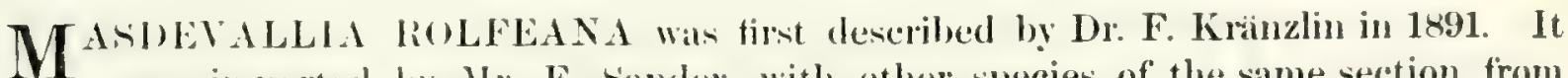
Was imported hy Mr. F. Sander, with other species of the same section, from the Central Cordillera of Costa Rica.

Explanation of I'late, Irawn from a plant at Sewhattle dbiser:

Fig. 1. petal. lip. and columm, in matural position ;-1:, section of ovary ; -2, petal, inner side ;-

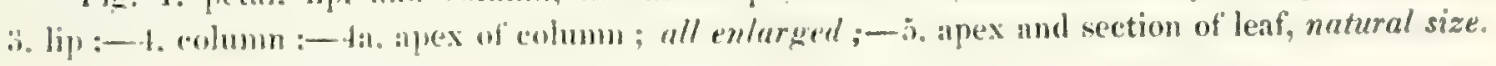






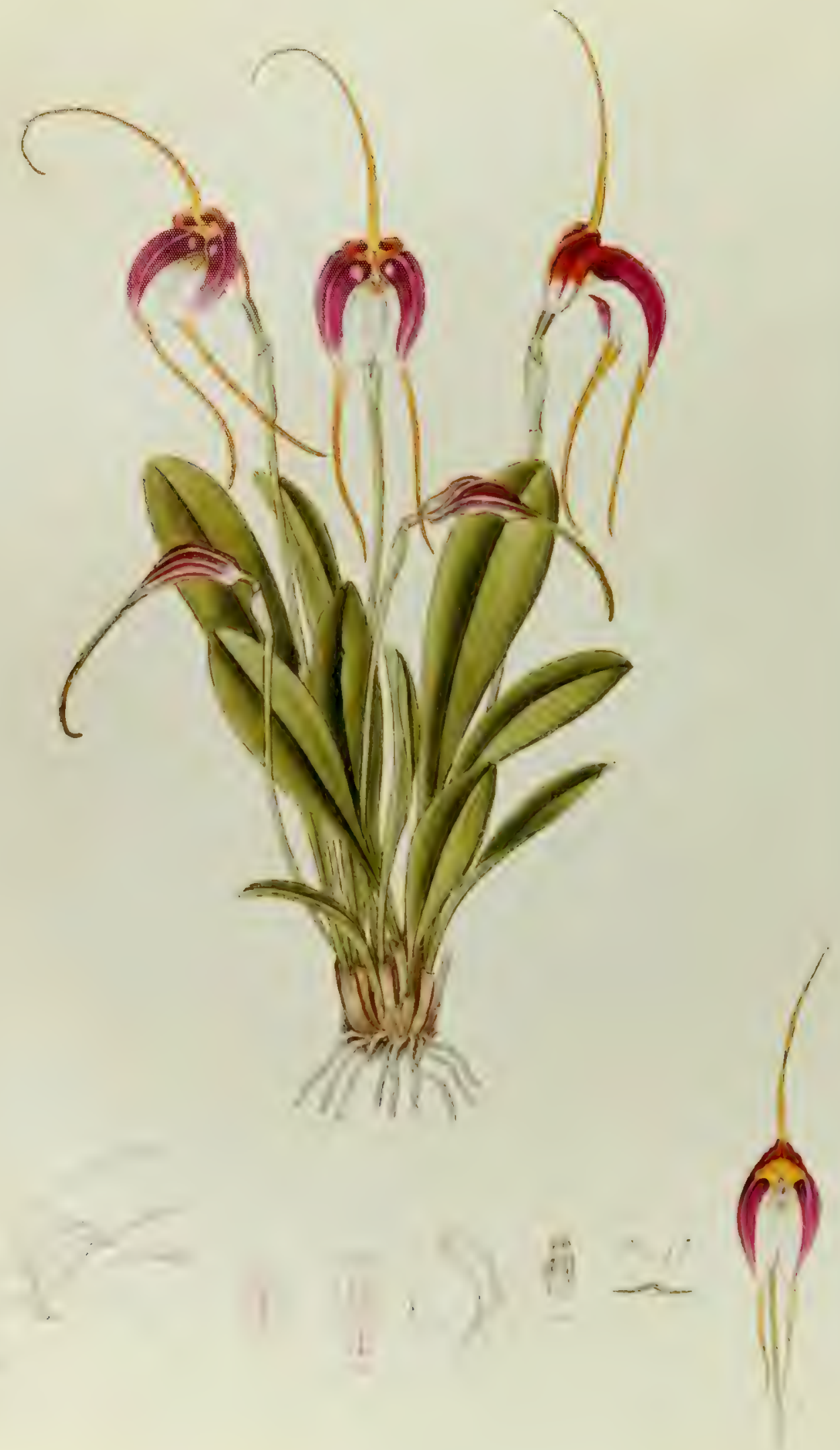




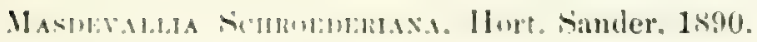

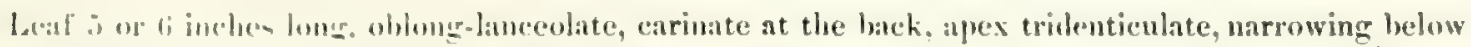

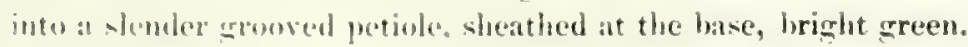

Pedumele 7 on inches lomp, terete, slender, erect from within the sheath at the base of the petiole, frale stent bract about 8 inch long, membranous, wate, apioulate, sheathing below, with a minute molimentare but within at the base, pale green.

Wirre 3 ind lone, with six rounded angles, pale green.

Sepals: dorsal sopal mited to the lateral sepals for is inch, forming a marow tube, free portion

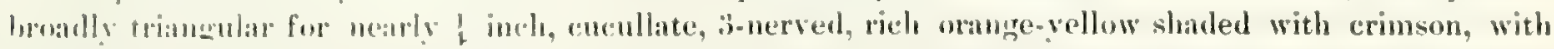

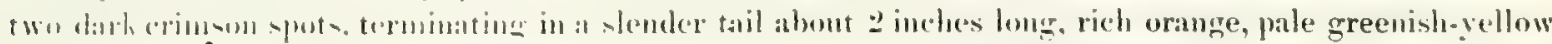
at the bas": lateral whils collering for more thin 1 inch, oblong-triangular, 3-nerved, the nerves

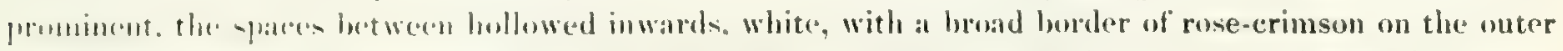

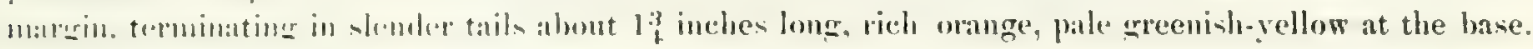

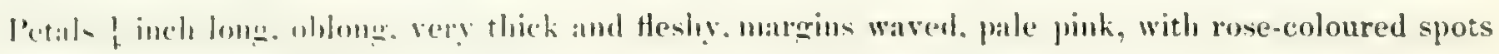
and it darker" "entral stripes.

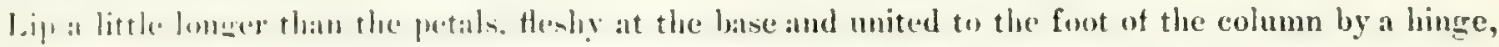
uhbun.- with wo -mall lomeritudinal beels mar the centre, apex recurved, pale pink, with a few darker Glots and a central line near the apex.

('olumn a little shorter than the petak, narrowly winged, atpex denticnlate, white, with pink spots.

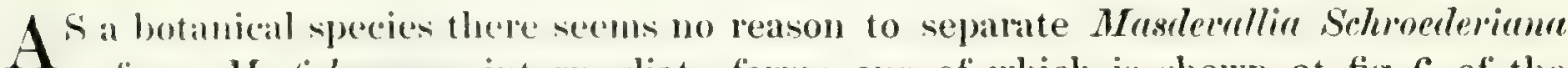
firom . 1\%. finlerserns. intermediate forms, one of which is shown at fig. 6 of the aceompanying Plate, connectiner the wo very closely. The structure of the two plants is rematially alike, and a description of one would apply equally well to the other, diflerences ocemoring only in size and in richness of colomring. Unfortunately, no

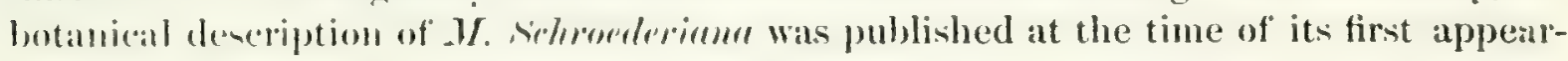
:11ner in Mr. Silnderve collection, although it was, and still is, adrertised in his catalogue muder this name. The Orelhid committee of the Royal Horticultural Society awaded a Firt-class ('ertificate. July sth, 18,0, to a plant then shown in flower by Baron sichoceler. whose name it hars, but it was not until September of the same year that

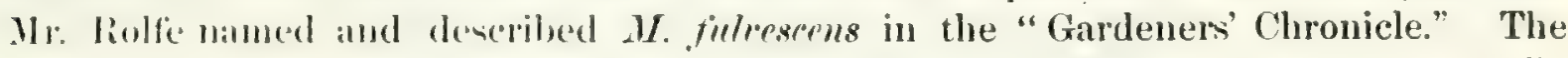

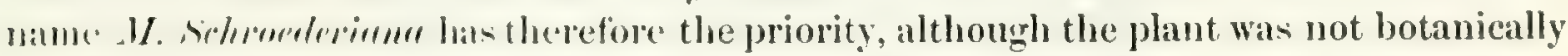
described, and it is to be respetted that this, the first introduced and finest form of the frecies, shombl not he comsidered the type. I have therefore decided to give a sepallate Plate of estreme forms of this plant, leaving it for future decision whether lhey should he comsidered distinct, or merely varieties of one species. Its habitat and discoscrere arro unknown.

Explanation of I'late, drawn fion a plant at Newbattle Abluey:

Figr. 1. petal, lip. and columm, in natural position;-1a, section of ovary ; - 2, petal, inner side ; -

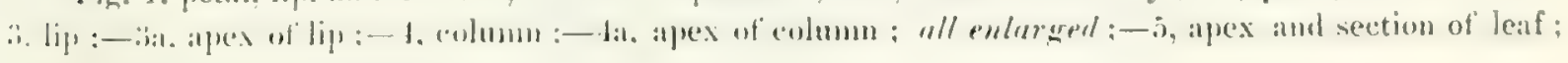
- li. variut! : mulural size. 



\section{SACCOLABLATAE Rchb. f.}

1 MOST distinct section, differing so essentially from the type of Marderallia, that Reichenhach would have been justified in forming it into another Genus, a course which he appears to have at one time contemplated. Many of the plants included in it are so entremely variable, and have in consequence received so many names, that it is difficult to decide which are species and which varieties.

12 species and two varieties figured :

Masdevallia bella Rehb. f:

Carderi Rehb. f.

Chestertonii Rehb. f. (=M. mucrochila Regel. $)$

Chimata Rehl). $f$.

Chimera var. Backhousimm.

Chimarat val. Roezlii.

erythrochate Rehb. f. (= M. astuta Rchl. t. et M. Gaskelliaun Rchb. f.)

Houttenua Rchb. f. (=M. Benedicti Rehb. to of M. prittacina Rchb. f.)

nycterina Rehb f.

pusilla Rolfe.

moliosa Rehb. f.

trinema Rchb. f. (=M. Lomii Rolfe.)

Trorlodytes Rehb. f.

Vespertilio Rehb. f:

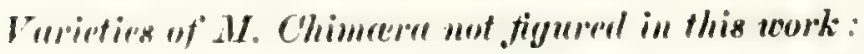

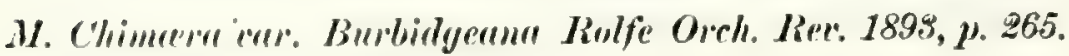

lolosen líchls. t: MS.

Goryourl Linel. C'ret. 1573.

suilis Jicht. t. Gard. Chrun. 1885, pt. II., p. 489.

secerel lichls. is Gurd. Chrom. 18\%5, jt. I., 1\%. 170.

splenelielor, horrt.

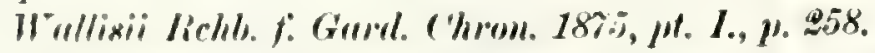

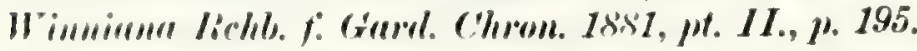

Vut in rultimtion:

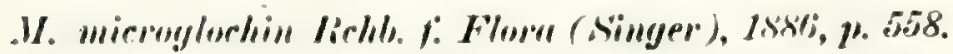

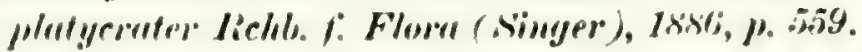

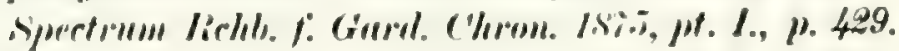

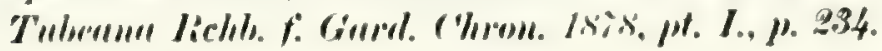







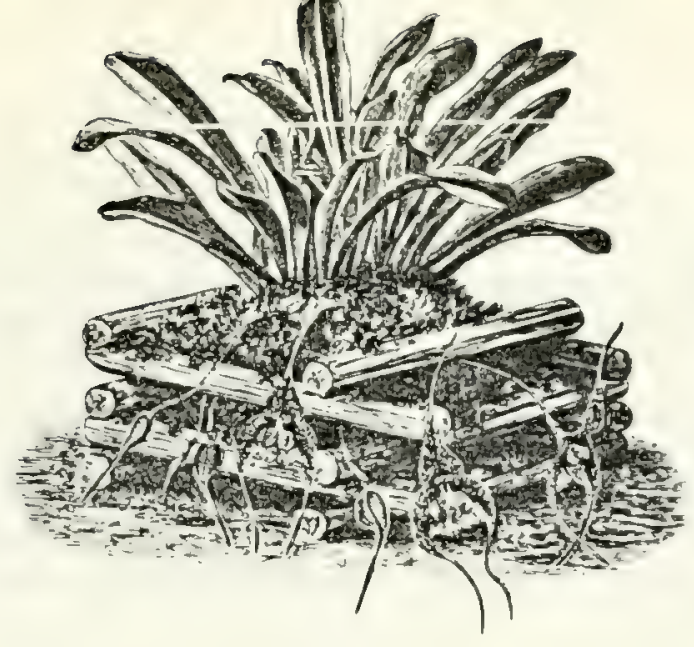

MASDEVALLIA BELLA Rehb. f.

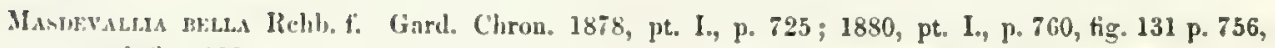
and fig. 132 p. 757 ; 1881 , pt. II., p. 236, fig. 50, and p. 846 ; Floral Mag. 1881, n. ser. t. 433; Belgique Horticole, 1884, vol. XXXIV. p. 57, t. 3.

Leaf 6 or 8 inches long, and about 1 incl, broad, oblong-lanceolate, sbarply tridenticulate, carinate, lright green, narrowing into a slender, deeply-grooved, pale-green petiole, sheathed at the base.

Peduncle 6 or 7 inclies long, attenunte towards the base, terete, jointed, with a sheathing bract at each joint, dark purple, or dull green shaled with purple, descending from the base of the petiole: Howering bract about ! inch long, with neveral nerves, carinate, apiculate, pale green shaded with purple or crimsm.

(Nary alout $f$ inch long, attenuste near the base, with six crenate kings, green and purple.

Scpals: clorsal mepal united to the lateral sepals for nearly 1 inch, 7 -nerved, triangular for 1 inch or more, tapering into a slonder tail $3 !$ inches long; lateral sepals cohering for about 1 inch, 7 .nerved, ovate. taprering into slender trils 3 inches Inng, sometimes curved inwards so as to cross each other; all sepals pale vellow, hordered and spotted with crimson, and covered with short thick hairs, inner balf of the lateral aepals scarcely sputted ; tails all jurple-crimson.

l'etals $\frac{1}{+}$ inch long, linear at the lane, angled on both margins, cleft at the apex, outwardly broadly winged, inwardly trinngular and denticulate, bright gellow spotted with rust-red, outer wing with uumcrous rodiating lines of minute payillee.

Lipl ahout ! inch loner, and 1 incl, brond, with a slender, fleshy, deeply-grooved claw, united by a deliente hinge to the base of the colmmn, reniform and concrve, with numerous radiating and bifurcating keels, white with pale pink spots upon the claw.

Colum ahout binch lung, thick, curved, rust-red, pink at the base, apex minutely denticulate.

M

ASDEVALLIA BELLA is one of the most curious of the genus, and may be distinguished from all other species by the delicate whiteness of the shell-like lip, and the romeled, wide-spreading yellow wings of the petals Unlike most species allied to it, $M$. belli apparently produces only one flower from each stem. It was discovered in 1873 by Gustar Willis, in the mountains of Antioquia, and his dried Apecincus were sent to Profenor Reichenbach, who, however, published his first deseription of the species from other specinens, collected in 1878 by Boxall. The first living flowess secn in Europe were in the collection of Herr Wendland, at Hamburgh. 

We are indebted to Consul Lehmann for the following information:

Masdevallir bella has but a limited geographical distribution, having been hitherto observed only in the vicinity of Frontino and Urao, on the Western declivities of Une Western Cordilleras of Antioquia. It grows on trees, and also on the rround, in dinup, and shady woods, at an elevation of 1,600 to 2,200 metres $(5,200$ to 7,150 feet), 111 d flowers in October and November. The ammul average temperature of the whole rengin ranges from $15^{\circ} \cdot 9$ to $19^{\circ} 4$ Centigrade (about $60^{\circ}$ to $\left(i 7^{\circ}\right.$ Falurenheit). The atmosphere in the entire region is highly saturated with mointure nearly the whole year round. The driest months of the year are January to March, and July and August, during which the average humidity is $75^{\circ}$ per cent. ; while for the rest of the year the average is st: per cent.

F. C. LeHmans.

Explanation of Plate, drawn from a plant at Newbattle Abbey:

Fig. 1, petal, lip, and column, in natural position;-1a, front of lip, both slighlly enlarged; -2, sectim of ovary ; -3 , petal, inner side:-4, column; $-4 n$, apex of column, all much enlarged; -5 , apex and section of leaf, natural size. 



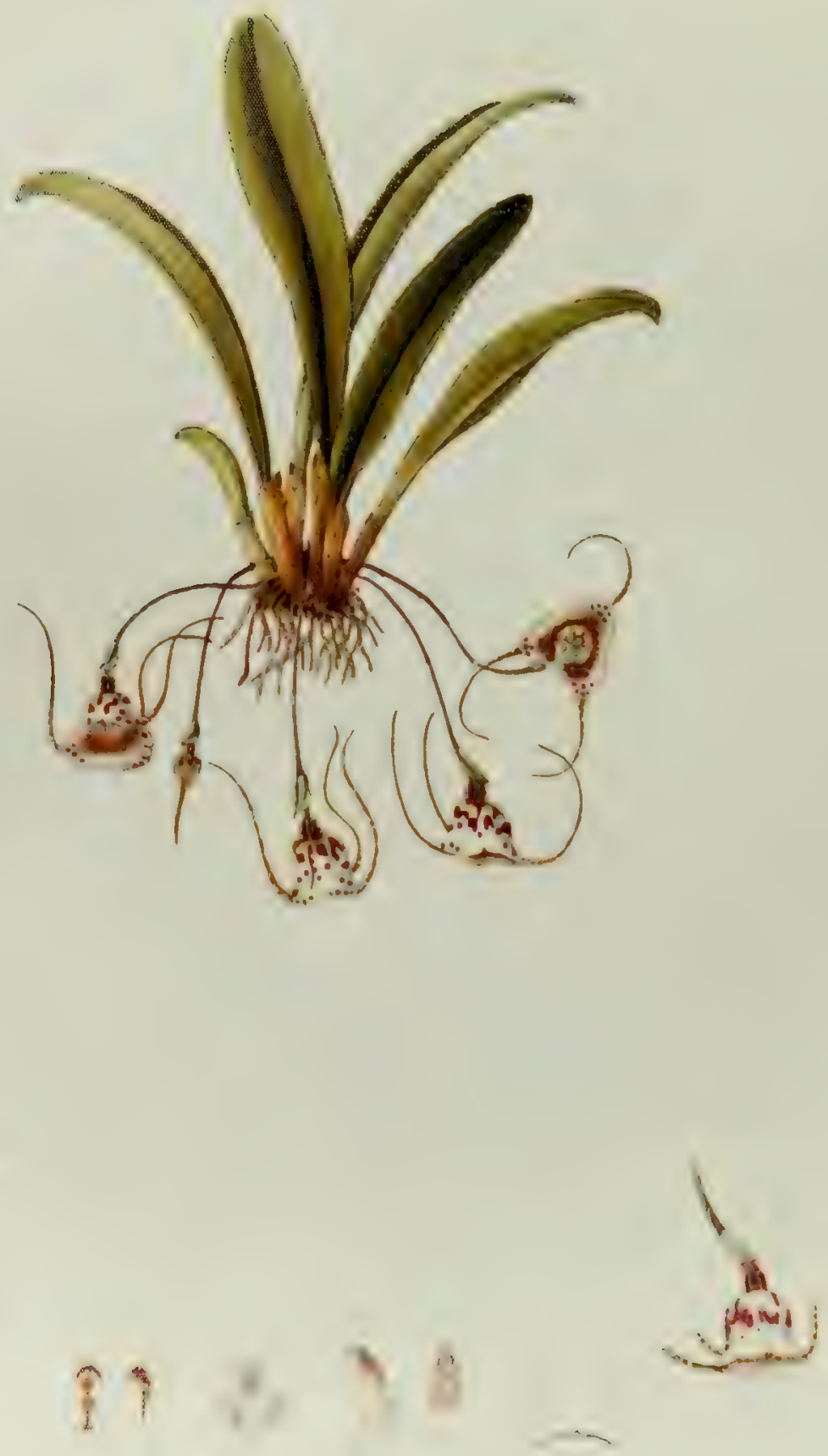


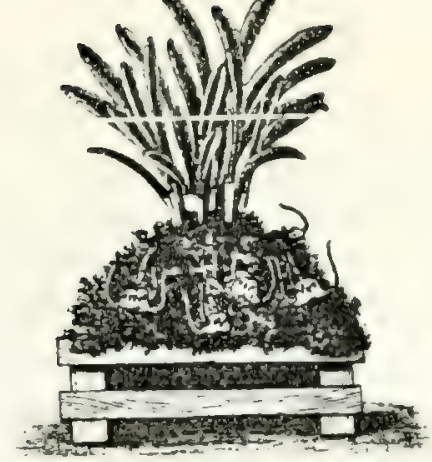

\section{MASDEVALLIA CARDERI Rehb. f.}

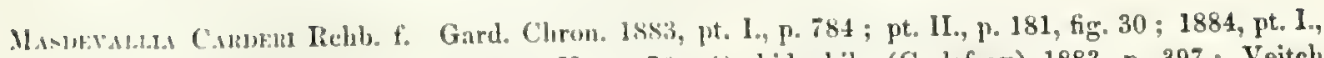
1. 741. in groul, fig. 141 ; 1890, jt. II., p. it; (Grchidophile (Godefroy) 1883, p. 397 ; Veitch

Mannal (Irch. pt. V. (1889), p. 27 ; 13ot. Ma!e. t. 7125 (1890).

Latol or 5 inclues lone. blong-lanceulate, carinate at the back, apex tridenticulate, bright green, naruwing heluw into a slender grouved petiole, sheathed at the base.

P'odumcle $=3$ inches long, descending or lateral from the base of the petiole, terete, slender, with munerum antall she:thing apiculate bracts, dark green and crimson; flowering bract about 3 inch long, ohlong-urate, carinate, apiculate, 3-nerved, sheathing, pale green.

(Wary nearly i inch long, crimson, with six crentte green wings.

Sepals cohcring equally for about inch, campanulate, free portion triangular-ovate for nearly 3 inch, the principal nerve carinate, white tinged with pale vellow, spotted externally with purplish-crimson, the interual - mface clonely covered with short red-hrown hair, and having a few small purple spots, each ofpal teruinating in very slender tails about 1 inch lone, yellow with small crimson spots.

l'ctals about binch Jong, oblong-ovate, cleft at the apex, with minute papilla within the cleft, vellowinh. with red-lyrown spots and papilla.

Lijpabout 1 inch hone, theshy at the base and deeply cleft, united to the foot of the column by a fiexilsle linge, anterior prortion concave, shell-like, with a fleshy central keel, pure white.

Colum ! inch hung, winged, apex denticulate, white, tinged with reddish-brown.

$\mathrm{M}^{-1}$

INIEVALLIA CARDERI was first deseribed by Professor Reichenbach in 1883, from specimens found by Carder near Frontino, in the Western Cordillera of Colombia, and his plants were the first to flower in cultivation, in the establishment of Messis Shutteworth and Carder, at Clapham.

Protesor Reichenbach had previously received dried flowers of this species from Comsul F. C. Lelomann, who discovered it in Yovember, 1877, and it is impossible to sity why he published no description of these, the first specimens ever sent to Europe.

The plant represented in the accompanying Plate is the variety with long slender tails. most common in cultivation. Fig. (6 of the same Plate represents the rarer variety with short blunt trils, and was drawn from a flower sent to me in June, 1889, by Mr. F. W. Moore, Director of the Royal Botanic Gardens, Glasnevin, Dublin.

I am informed by Consul Lelomamn that the leaves of the wild plants having thick and short-tailed flowers, differ from those of the slender long-tailed variety in being

Explanation of Plate, drawn from it plant at Newbattle Abbey:

Fig. 1. pretal, lip, and columu, in satural position; - la, section of ovary :-2, petal, inner side ; 22 , peral, wide view: -3 , lip :-t, colum ; - ti, spex of column; all enlarged; -5 , spex and section of leaf, uatural size; - - fo. Hower of short-tailed variety, naheral size. 

longer, thicker, and more acuminate, while the flowers are of thicker texture and more tubular. These chancteristics I find to be also present in cultisated plants. The two forms can only be regarded as local varieties, their variation probably accounted for by the different elevation and temperature of the localities in which they grow.

\section{I have received the following note from Consul Lehmanu:}

The rariety of Masdevallin Carderi with long slender tails comes from the neighbourhood of the Rio Dagua, in tbe Western Andes of Cali, in the State of Canca, Colombia, where it crows on trees in dense, very damp woods at an elevation of 400 to 800 metres (1,300 to 2,600 feet), in a temproture of $24^{\circ}$ and $25^{\circ}$ Centigrade (ahout $75^{\circ}$ to $77^{\circ}$ Fahrenheit).

The short-tailed variety is found in Antioquia, where it grows on treen in dense shrubly wouds ons the Iracál and Musinga mountains hetween Dabeiba and Frontino, at a greater elevation, 800 to 1, fou mitres $\left(2,600\right.$ to 4,550 feet); and in a lower temperature, only $21^{\circ}$ to $22^{\circ}$ Centigrade (about wito to il Fahrenheit).

The climate of hoth localities is very damp, and the rainfall is profuse and constant. There in In! really dry season in these regions, but during the months of July and August, and of January ami February, the rains are not so loeary and frequent as during the other months of the yenr.

In a wild state $M$. Carderi Howers from Octoher until December, and during May and June. 




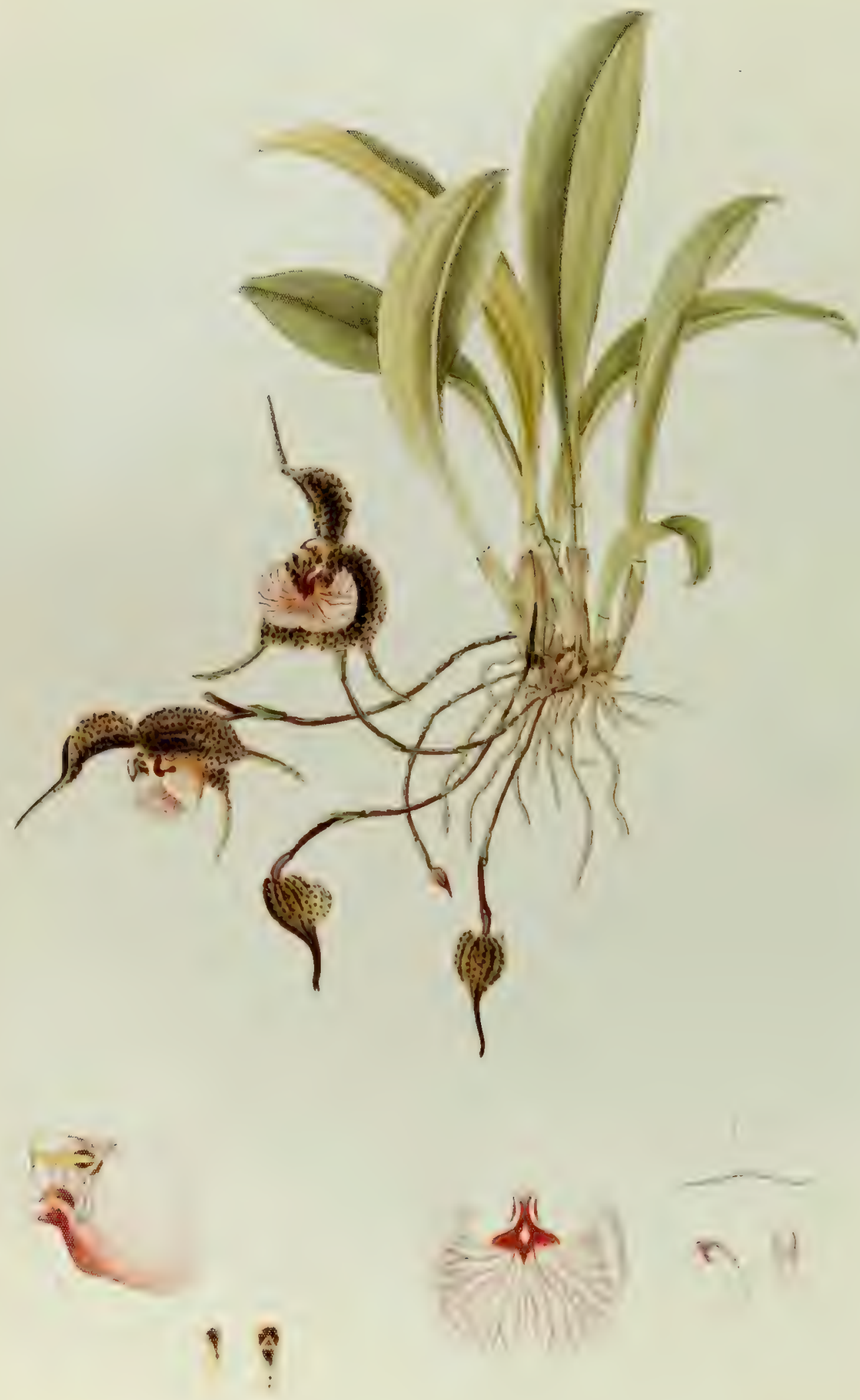




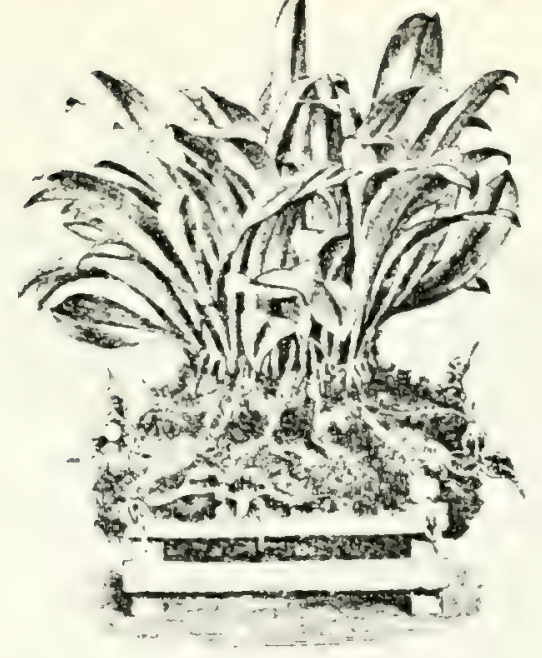

MASDEVALLIA CHESTERTONII Rchb. f.

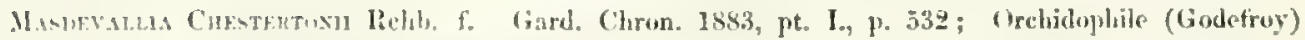

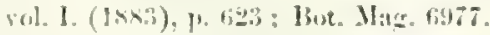

Lest $j$ or $f$ inches long. 1 or 1 i ibroh whle, oblong, earinate, acutely tridenticulite. bright green. narrowing into a slender, sromed, pale crecen jetiole, with wide membranous sheatlis at the bane.

Peducle 3 or 4 inche lony, horizontal, ur descending from the base of the protiole, tarete, witb muncruss sluathins bricts, lull areen sometines suarked with purple; producing two or three flowers, and flower falling off lefore the expmusion of the next; Howering bract about 1 inch lone, 3 -nerved. apiculate, corinate, light green.

"bary 1 inch long, terete, with six groeves, curved, dull green or pungle.

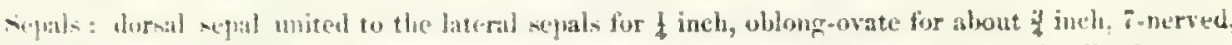

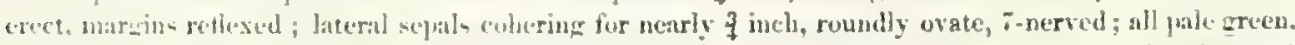

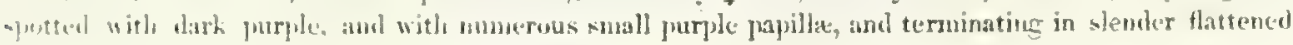
raik abut inch long, dark purplo ur zreenish.

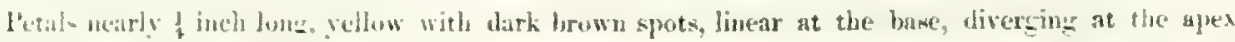

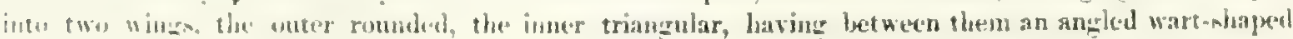
frocens. darth bruwn and shining.

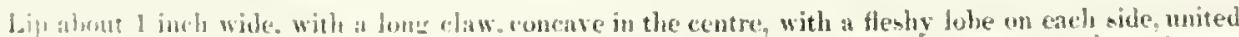
ly is hinge to the fues af the colum, anterior portien reniform, with a prominent reddish central heel and

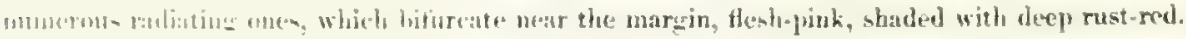

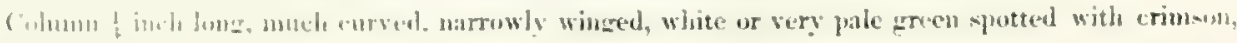

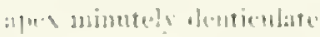

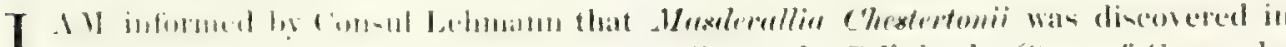

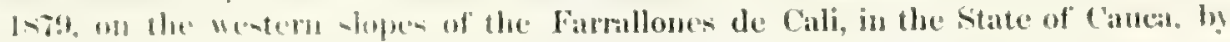

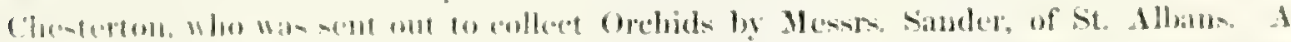

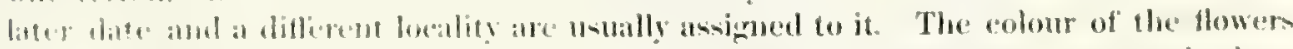

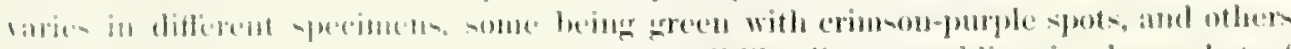

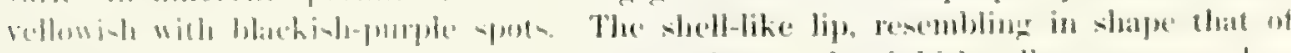

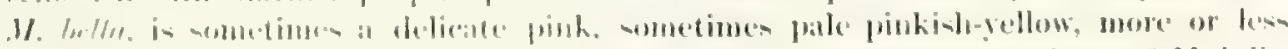

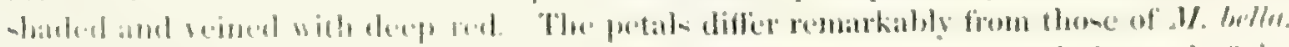

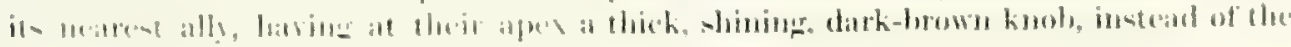

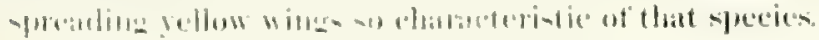





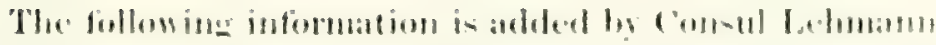

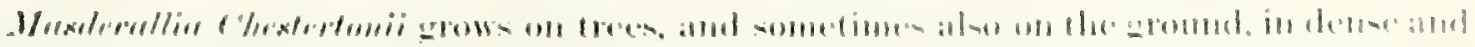

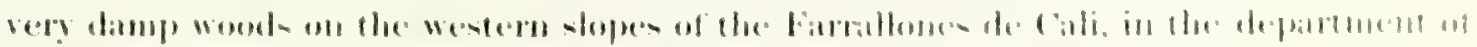

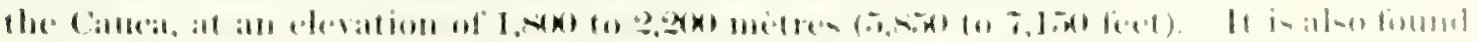

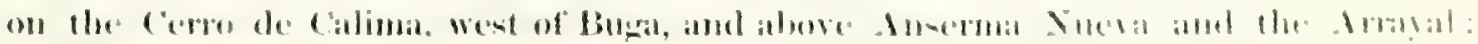

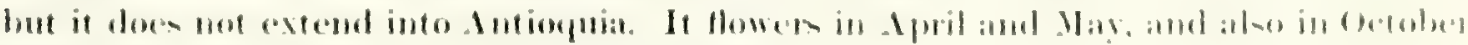

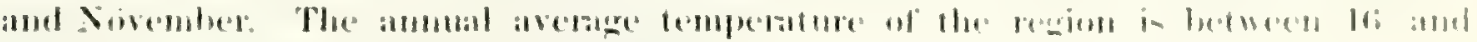

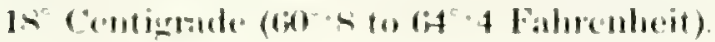

$$
\text { I. 1. 1.111112 }
$$

Explanstion of Plate. elrawn from a plant at Xiewbattle dhley:

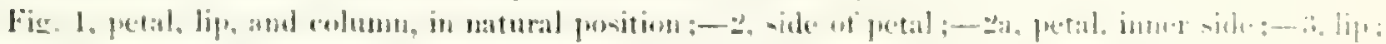

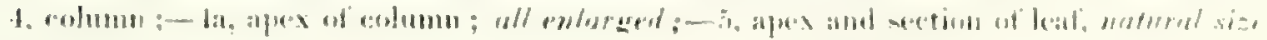







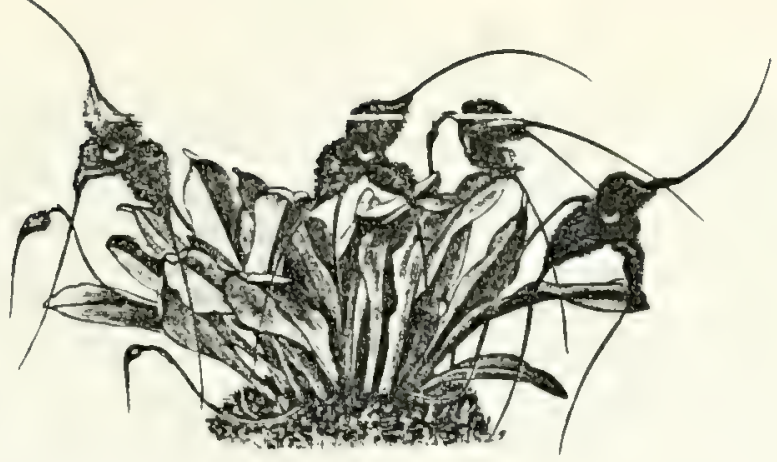

\section{MASIEVALILA CHIMARA Rehb. f.}

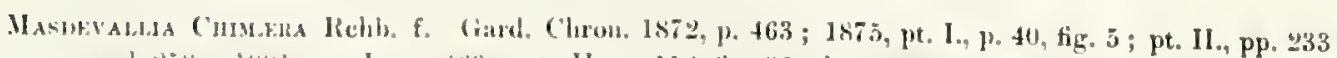

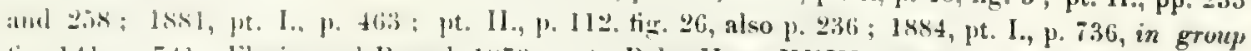
fic. 141, 1. 741 : lilorint and l'omol. 1873, p. 2 ; Beler. Hort. XXIII. (1873), p. $355 ;$ XXV. (1875),

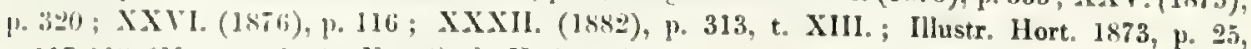

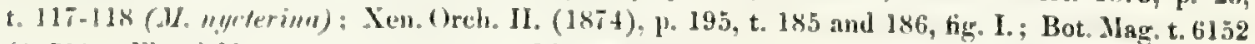
(165i) : Floral Mat. 11. \&. 1875, t. 149; Limaxa XLI. (1875), p. \&; De Puydt, Les Orch. (1880), 1. 20.5. pl. XXIII. (.1\%. "y.terinu); Revue Hort. 1881, p. 130, with fig.; Orchidophile (Godefroy),

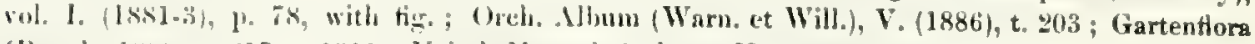

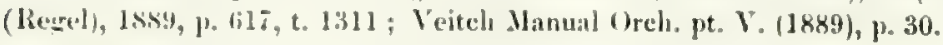

l.coff $x$ or 10 inches lonir and 11 to 2 inches wirle, oblanceolate, sometimes plicate, carinate at the back. apux acutely tridenticulate, bright green. narrowing helow into a pale green petiole with brown membliranous sheaths at the liase.

I'edumele "s to 18 inches lome, terete, wiry, crest. Interal, or descending from the base of the petiole, dark green or tull purple, with many appressed bracts, flowers two to six, opening in succession, each falling off hefore the expamsion of the next, the peduncle lengthening as each bud developes, flowering bracts ublome-ovite, acutely apicnlate, shenthing below, bright green.

Wary abont 3 inch long, with six romed angles, dull green or purplish.

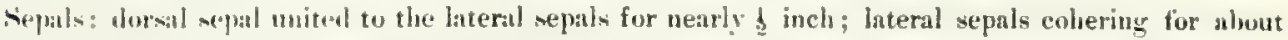
1! inch. deeply curved at the back; all wate for 2 or $2 \frac{1}{2}$ inches and terminating in slender tapering dark

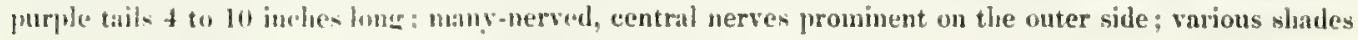
uf prinruse. cream, of ochure yellow; staned and spotted with crinson-purple, more or less bright, and thichly atudided with course tapering hairs, the spots and hairs hecoming very small near the centre.

l'etals in inch lonw, spathulate. the apex divided into two rounded lobes, between which is a unass of alimine papillite, white and crimson or purple.

Lif almut inch lome, the basal part Hesliv, errowed, slining, united to the foot of the columu by a Hexiblo hines. the anteriug part siccate, with one or three central longitudinal heels, more or less frominem, with numcoms ray, diverering towards the margin, where they terminate in strong incurved

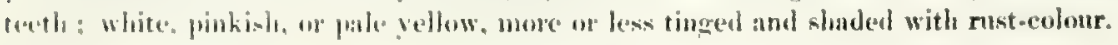

Cohum meher longer than the petals. pale vellow or whitish, apex minutely denticulate, foot pale pink.

$\mathrm{M}$

ISIIENALLIA ('IIII.ERA was diseovered in Matrch 1870, by Roezl, at Choco, in the: Western Andes of Colombia, 7,400 feet above the level of the sea, and from onte bally dried flower and a coloumed steteh sent by him, Professor Reichenhach named the plant. Xo living specimens were introduced until some time afterwards, the first which flowered in coltivation being appatrently those sent to Rejchenbach hy Mr. Bull

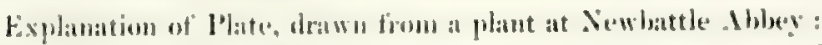

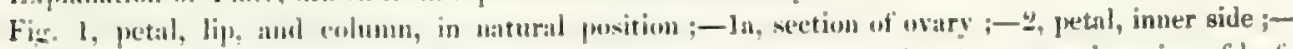

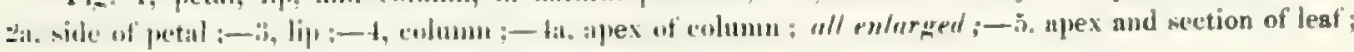

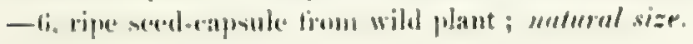



in 1875. Both Roezl and Wallis, while collectiner M. Chimero, olmerved its extrense variability, but although several varieties sent bome by them recersed specific names from Reichenbach, he seems never to have quite decided whether to treat the'm an distinet species, or as forms of the original $\mathbf{N}$. Chimeere of Roez. The varieties now in cultivation are so numerous that they form a tolembly consecutive series, and it is well known that throughout the vast geographical mage of the speceies mant other variedie exist, a fact which sets at rest all doubt as to the polymorphous chameter of the phan.

In order to realise the wonderful variation of $M$. ('himeren, anyone interested in the subject could not do better than visit the rich eollection bronght together att Glasnevin, Dublin, by $\mathbf{M r}$. F. W. Moore, to whom I an indehted for many heantiful and curious varieties. It is proposed to figure in the present work a few of those hest known in cultivation, and by dealing with each one separately, the numbere can be anderl 10 an ayy time. The plant here represented was imported by Mr. Bull, and was onc of the fist to flower in this country. The seed-capsule, figr. 6, wats drawn from a speciuncu at the Satural History Museum, South Kensiugton, dried after the edges lated split operu and allowed the seeds to escape, thus showing the hair-like threads b! which the seds were attached to the inner surface of the capsule. The structure of every part of the flower presents interesting and peculiar characteristics, the uses of which in the lifehistory of the plaut can only be sumised. The aloundance of ripe seeds prodeced ln

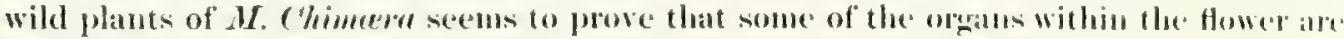
eflective in attracting insects, although there is no honey or ofleer tempting flud to ane as a lure. The suceessive development of the flowers may possibly be designed as an additional means to ensure the production of seed; if onc flower fails, another can lec mpidty exponded, until all the buds have been doreloped, and ererg opportunity las been given for the appeannes of the insect necessary to fertilise the seed. In a cultivated state, when the flowers have but a sumall chance of fertilisation by insects and therefore rarely produce seed, the stem goes on developing flower after flower in uninterrupted succession, each one fading and falling off' before the expansion of the suceeding bud. This is shown in the acempanying Plate by the stem bearing one hul and four small stalks, from each of which both flower and sece-calpsule hare fallen. Lu the wild specimen shown at fig. 6 , the second bud may be seen in quite an elementary statge of growth, the first flower having probably been fertibined ly some insed, and the effort required by the plant to ripen the seed having temponsils arrested the weowth of the next bud.

The following note is contributed by Consul Lelmanu, whose botanical reneanchen during a long residence anong the mountains of ('olombiat entitle him to be combiflered the greatest authority upon the fion of thit region.

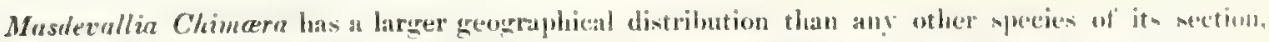
extending in an uninterrupted line from $0^{\circ} 30^{\circ}$ to $8^{\circ} \mathrm{N}$. Lat., or about 400 milen, alome the western decelivities of the Western Andes of Colomibia. It is chietly contined to the wentern slopess but at the mont merthern

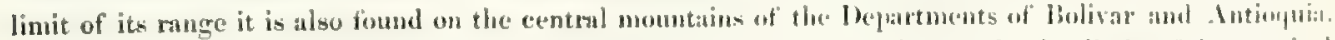
From 1,700 to 2,200 metres $(5,525$ to 7,150 feet) above the level of the sea is the limit of ito rerrieal

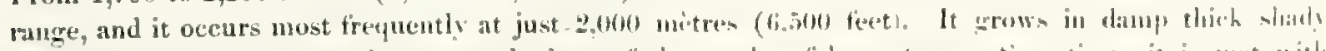
woods, chiefly on the ground, or upon the base of the trunh of larpe trees. Sumetimes it is met wirli upon damp shady walls of rock, if they are not muth covered with firms or ather veretation. Whint

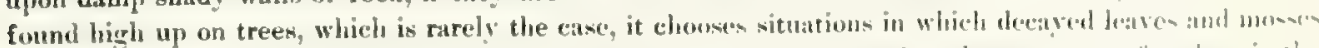

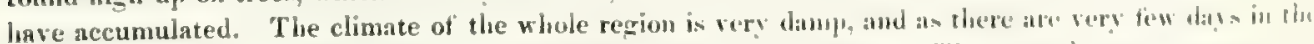

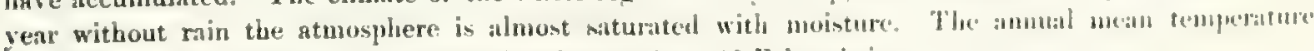
rangen between $16^{\circ}$ and $18^{\circ} .5$ ('entigrade ubout $60^{2}$ to $60^{\circ}$ Filhenheit).

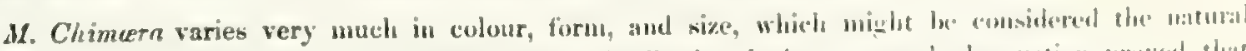

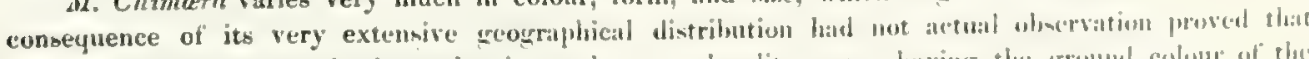

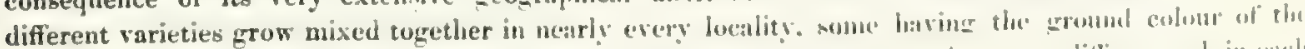

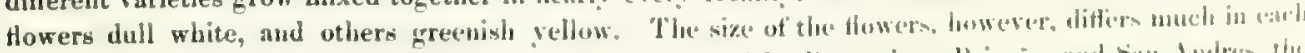

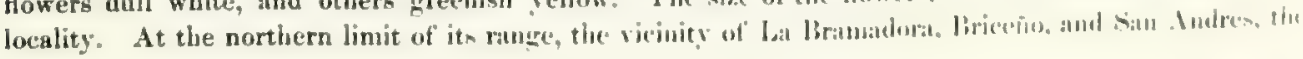





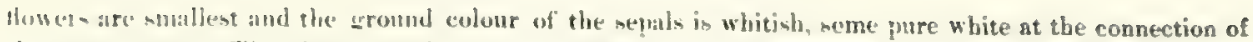
the latcral sejalm. The plants growing on the waterslied of the Cordillera between Toyo and Cañagordas, (a) the -henes of the Morrogatein and the Alto de las Alegrias near Alriaqui, and on the Cerro Plateado near Frontino, produes flowers of a groml medimn nize. Their colour is here most rariable. At Toyo Phere is a variety with thwer of a peculiar reddish colour stinined with copper-brown and borne on stifl 11pright stalks. In the plants growing on the Cerro Plateado near Frontino, the flowers are tiger-like, thickly riveckled (not blotched) rith blackish-brown on a light yellow ground. From the Cerro de ('aramanta, authwards ly the Altus de Talmani, and the Cerro de Calima as far as the Farallones de

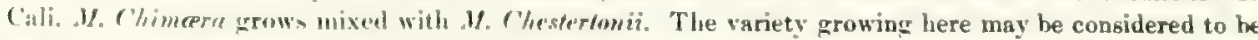

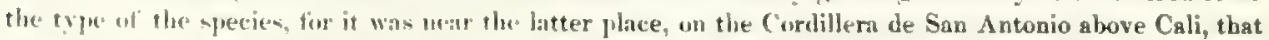
IReepl tirst wet with it. lboth the yellow and the whitish variety grow intermixed here. The latter as a rule prominces the larsent Howers, while the rellow form is more substantial and decidedly prettier. The larcest Howered variety grows at a placu called Bellavista, on a narrow rocky range of mountains projecting from the Curro Ifunchigue, in the Western Indes of Popayin, and running north-west towards Menchergue and Vicay un the l'acific. The plants here grow chietly on rockis among sphagnium moss, and hear upricht thower-atalix, which often attain the length of 25 to 35 centimètres (about 10 to 14 inches), thus misitug the flowers up above the leaves. Roezl's statement, that he found plants with Howerstalks wo teet long, is an exagueration. Near the frontier of Fcuador on the road from Tuquerres to Barbacoas, near the little village of Punmwuer, there growe a rariety urth flowers streaked ratber than Monthed with blackish-hrown, but the characteristic lip of the species remains unmodified. The plant lure represented is found in the Western Andes of Cali, in Cauca. 



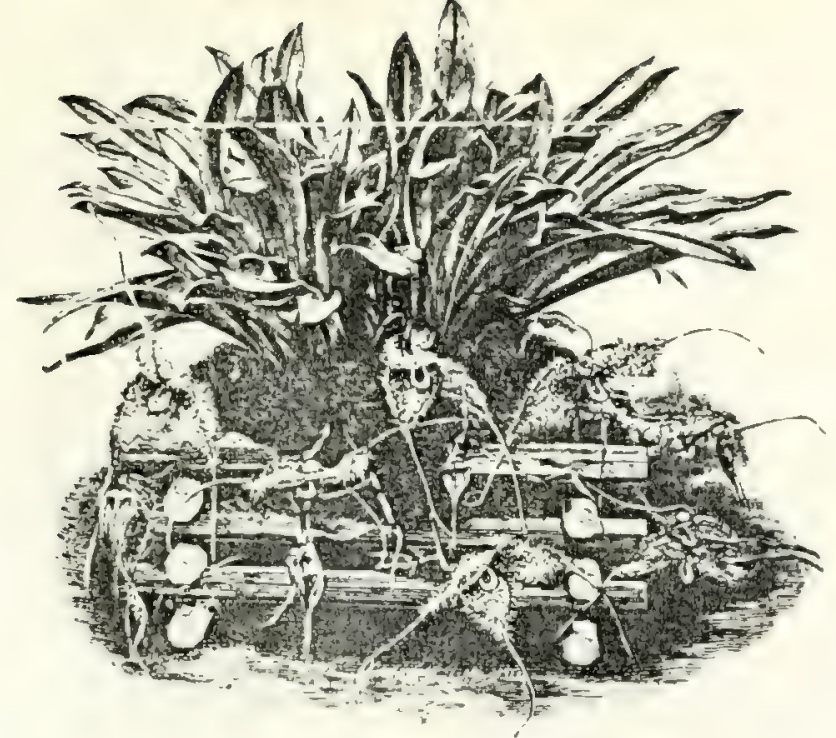

\section{MASINEVALLIA ('HIMAZRA Rehb. f. var. BACKHOCSIANA.}

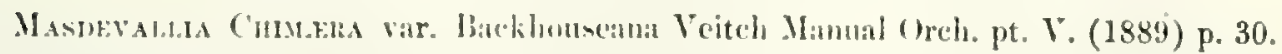

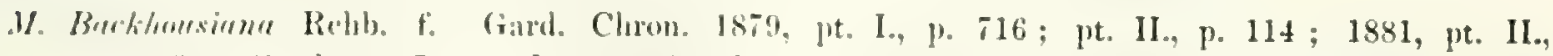

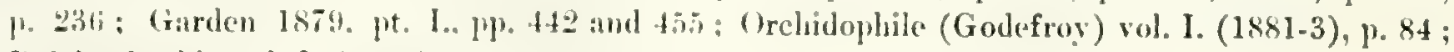
lieichenbachia rol. I. (INSs). p. 4i. t. 19.

Tllis handsome rariety of $M$. ('himeren was discorered in 1871, near Frontino in Antiofuia. by Butler. a collector for Mesrs. Backhouse of York, and it has also been found further south, m the Western Andes of Popayan. It was provisionally named hy l'rofesion Rejehembach ats a distinct species, with the renurk that if "commerting linkis" slomkl appenr between this and other forms of M. Chimerre, the plant must be regamded as merely a variely. Connecting links have indeced appeared in the shape of numerous forms and varieties of this most variable plant subse(puently imported from many localitices in the Western Colelillems of Colombia.

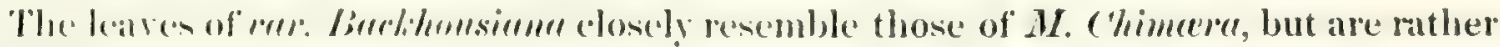

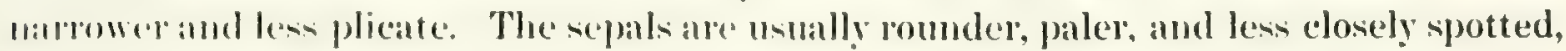
and the taik are comparatively short, the stems also being short and never erect. The ta! - within the hip-Which. in this varicty, is almost white-also show slight differences, but this chatracteristic does not appeat to be constant, even in flowers from the same phat. and is mot therefore of much value in distingushing onc variety from another. I an informed he comsul I dehmam that the plant here figured is found at Bramadom and Bricenio. in Antioguia, and that it is often much paler in colour.

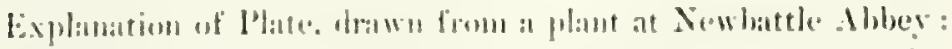

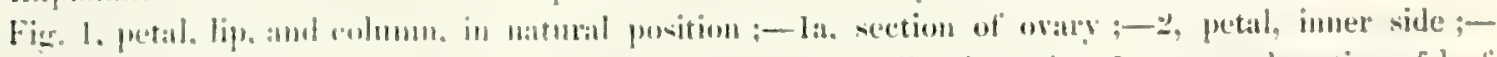

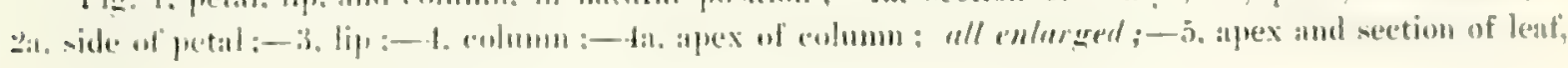
mulurul sizen. 




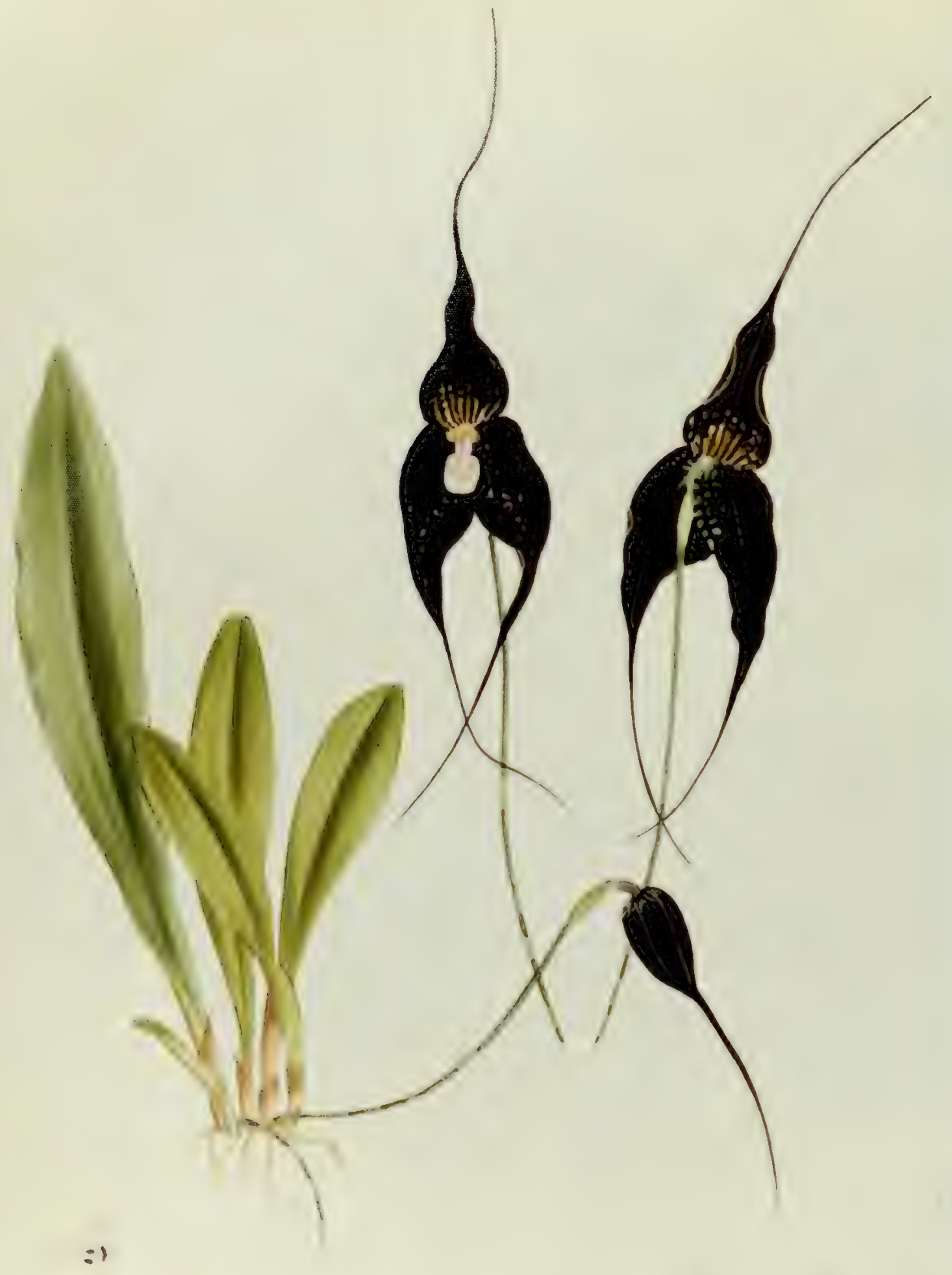




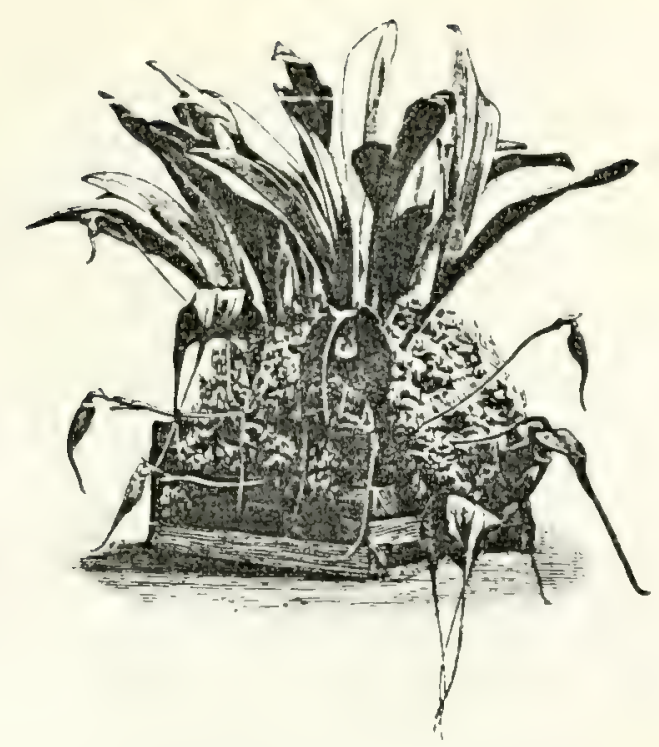

\section{MASIDEVALIA CHIMAERA Rchb. f. var. ROEZLII.}

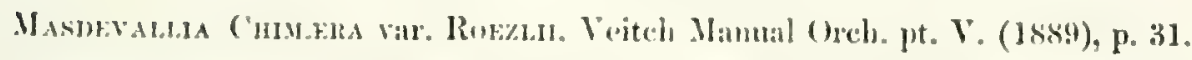

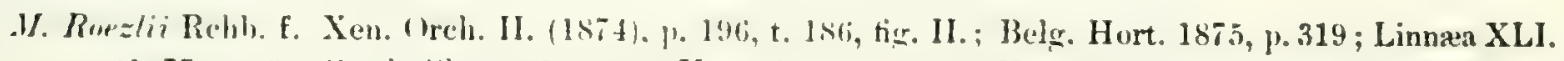

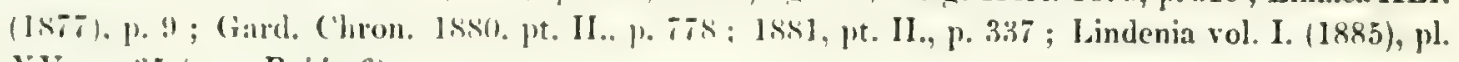
IV.. 1. 3.

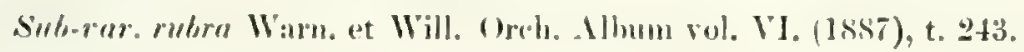

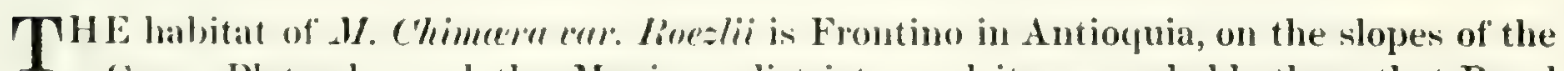
('erro Plateado. and the Mucinga districts, and it was probably there that Roezl discovered it. althomels no exact locality is given by Professor Reichenbach in his tirst dencription from Roegl's specincms in 1874. It is the darkest in colour of all the varieties of .H. r'himmer. the hack-purple spots being suffused orer almost the whole surface of the sepals. The most remarkable variation in ro. Ropalii from the type is the absence of Iong hairs upon the sepals, these bejug rephaced by numerous short warts or asperities. 'The lip is wider and shallower than in 21. ('himare, and pale pink with no tinge of yellow. It was probably these marted chancteristics which led Professor Reichenbach io comsider M. Konslii a distinct species, while he admitted that his $M$. Bachhmeirma might ultimately prove to be only a variety. Sub-varieties of mor. Ronzlii are numerous, less spotted or baler in colour. the brightest being sub-ror. mbru, in which the spots are chocolate-(')imson insteat of hack.

Explanation of l'ate. draws from a plant at Newbattle Abbey:

Fir. 1. putal, lip. and cohmm. in natural pusition ; 18. section of ovary ;-2, petal, side view :-

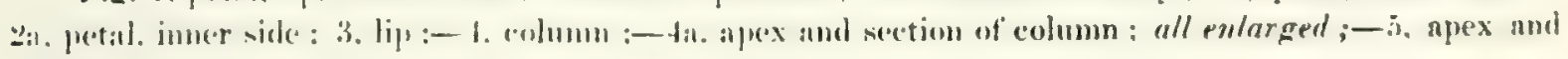
enertion of leatio molurul size. 




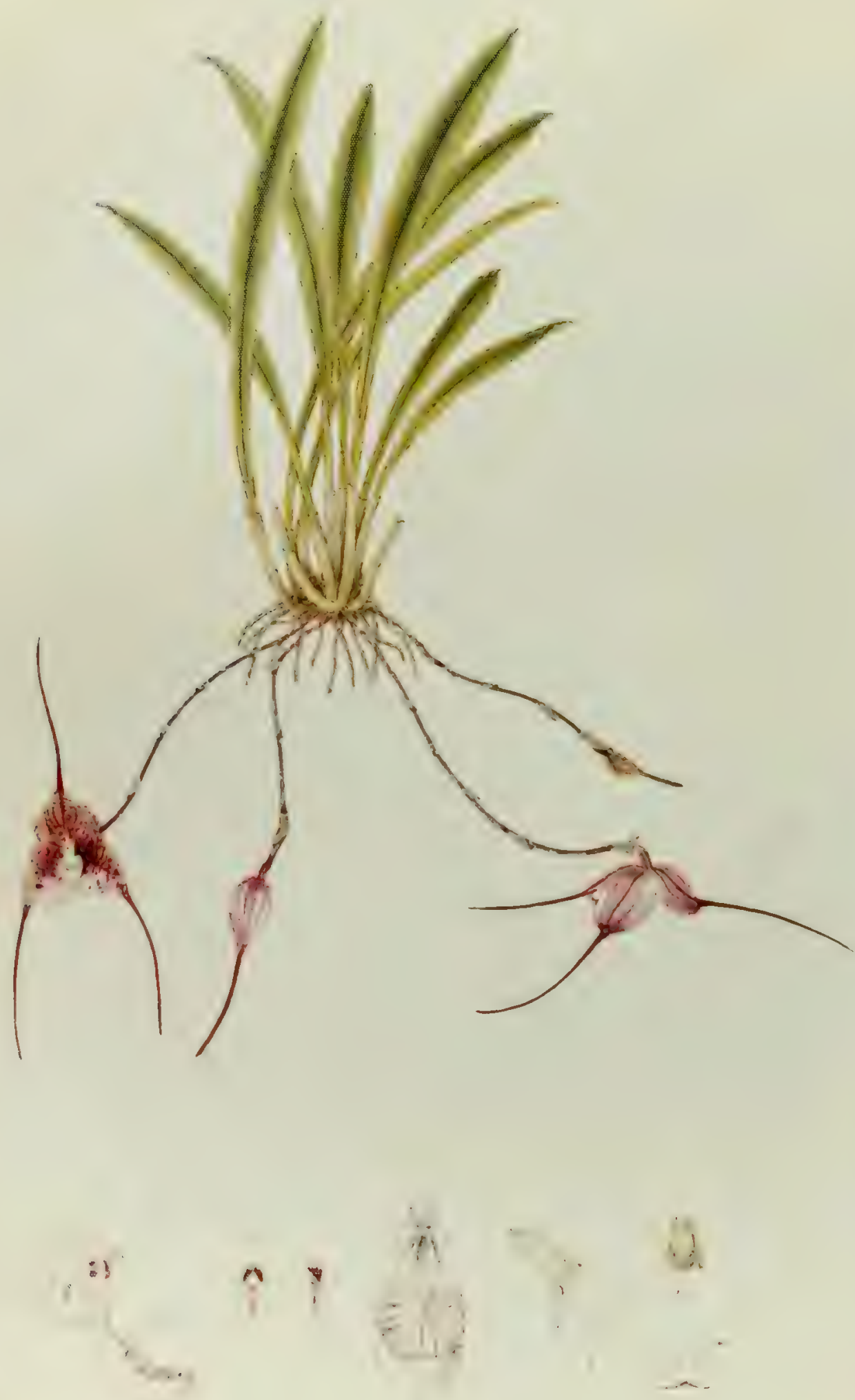



Plants of $M$, erythrochete with very long narrow leaves have been fouml in Costat Rica lsy Consul Lebmanu, growing on the Candelaria Momtaius, and very closely allied specimens have also been found by him in Antioquia. It is propably a species of wide geographical distribution, extending in varying forms from costa Rica southwards into the Corlilleras of South America. 



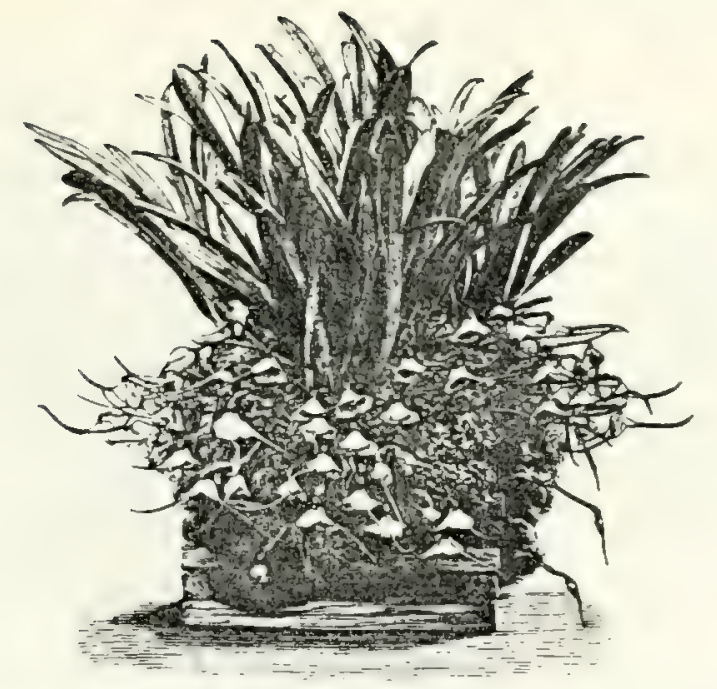

\section{MASDEVALILIA HOUTTEANA Rchb. f.}

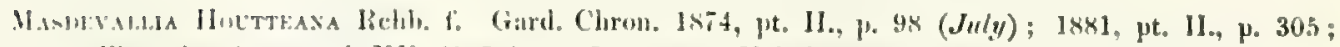
FFlone den Sirres vol. XX. (1אit), 1. s7, t. 2160; Veiteh Manual Oreh. pt. V. (1889), p. 45.

11. Bemelicti lichb. 6. Xen. Oruh. II. (1sit), 1. 197, t. 1s6, figs. III. and IV, (Derember); Linnata

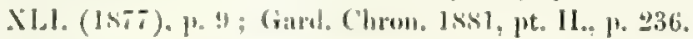

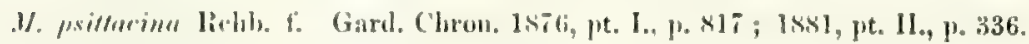

Lail ti of $\mathrm{K}$ inches long and ghout ! inch wide, linear, carinate at the lack, apex tridenticulate, bright wren. the peting very. little narrower than the hade. palc green, sheathed at the base.

l'aburele, including pedicel, $f$ or in inches long. terete. slender, descending or lateril from the base of the pertolu, with mumerous short apiculate shenthing bracts, dull green marked with dark purple;

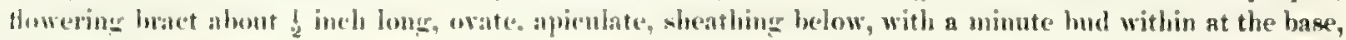
erreeroliah.

(1)ary abut inch lone, with six roumled angles, dull crimson.

Sipuls: dorsil sepal united to the lateral sepals for about $\frac{1}{2}$ inch, forming a wide tube, free portion alunt b inch long. ovatestriangular, s-nerved: lateral sepals cohering for nearly 1 inch, free portions roumdly srimerular : all cream-colonr tinered with vellow, with numerous small crimson spots and short thich hair or pappillax, and ferminating in dull crimson tails abut 13 or 2 inches long.

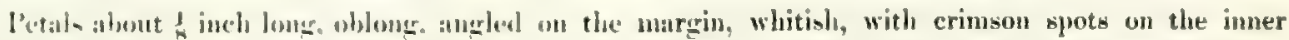
arfaces apex bilohed. with a mass of minute paynillat between the lobes, outer lobe yellow, inner white.

Lip alome is incla long. curved and fleslys at the lase, with a deep oval hollow in the centre, united to

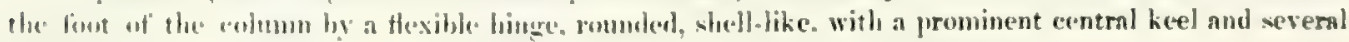

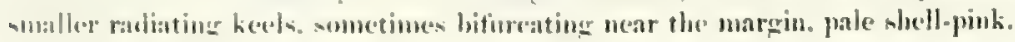

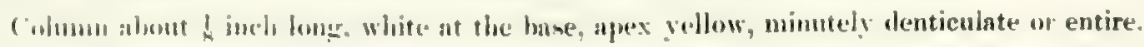

MASIDLALLLA HOLTTEANA was disorered ly Roezl near Frontino in the Western Cordillems of Antioguia, at an elevition of 8,000 feet, snd his dried

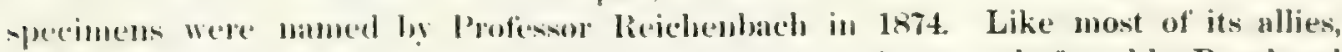

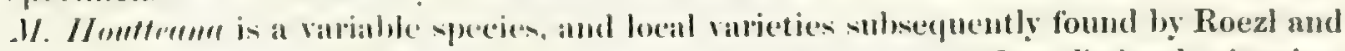

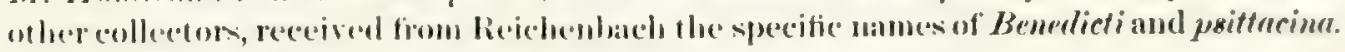

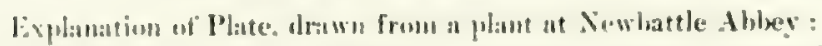

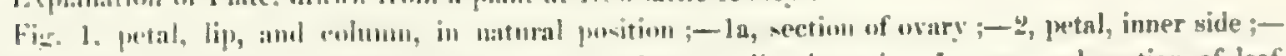

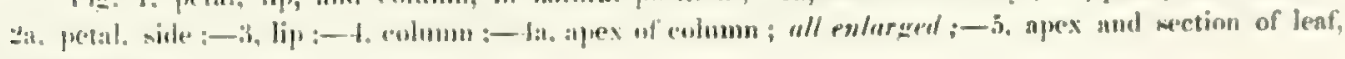
unfural size. 

They differ slighty from the type in the size and colouring of the flowers, and atre nes longer considered to be specifically distinct.

I am informed by Consul Lehmann that he has found this species near El Retiro, and also in damp woods between Itagni and Eliconia, in Antiopuia, at an elevation of 1,800 to 2,300 metres $(5,850$ to 7,475 feet $)$. In a wild state it flowess twice in the year, during April and May, and again in October and November. It grows anong coppse or brush-wond, generally on the gromd, but sometimes also on the mosy trumtis of treen. the long narrow leaves forming very dense masses, fiom among which the flowe as apear in great abundance, like a thick fringe upon the outer edge of the planto, a characteristic retained in cultiration and well shown in the nceompanying wood-cut. 




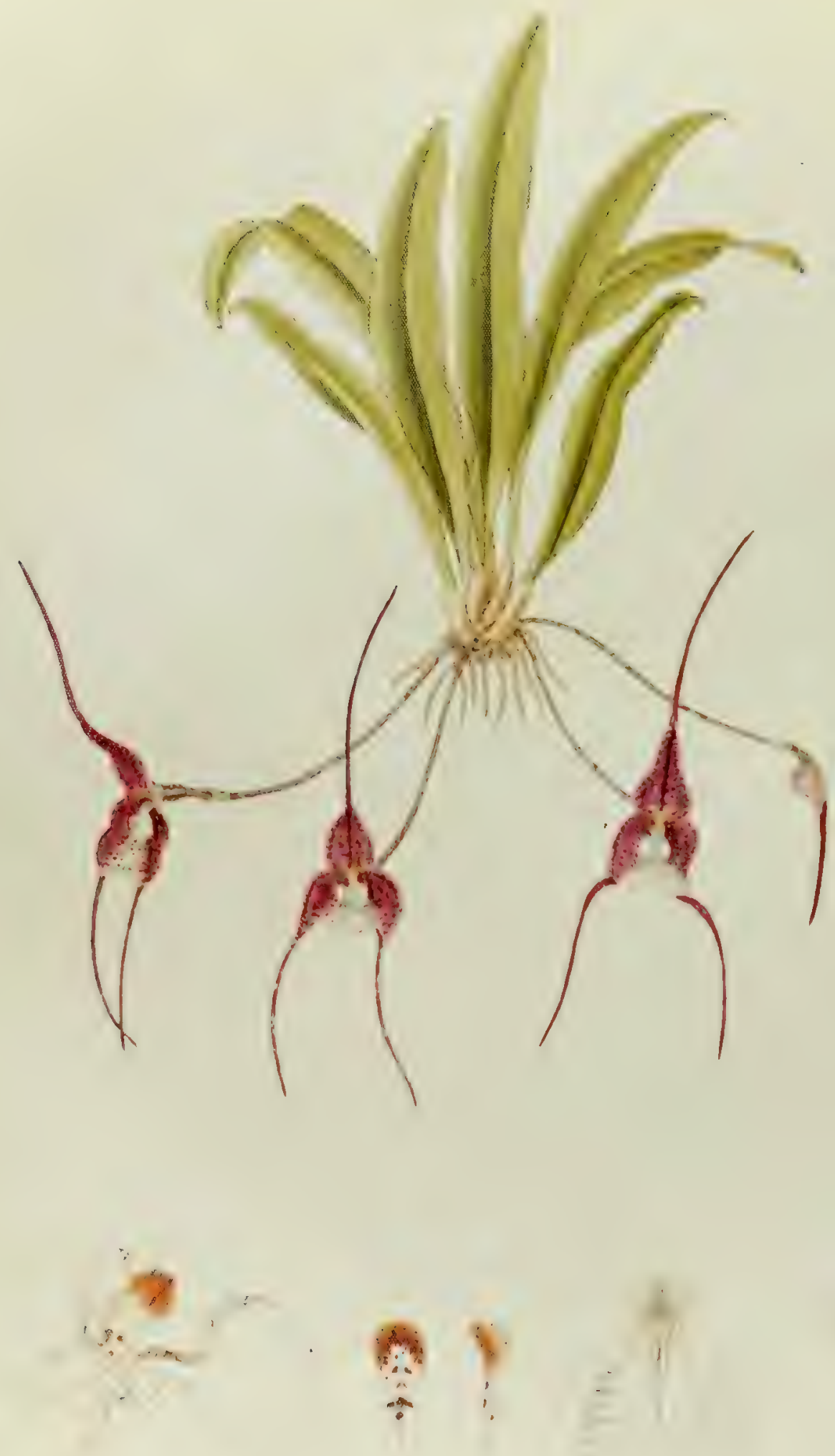




\section{MASIEVALLIA NYCTERINA Rehb. f.}

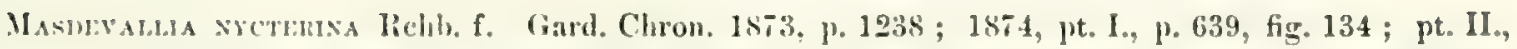
p. 75 ; 1875. pt. I., Pl. 40 and 106 ; 1\$s1, pt. II., Pp. 336 and 337, fig. 64; Hlustr. Hort. 1573, p. 25, t. $118.11 \mathrm{~s}$ (1s, 11. Chimarn); Floral Mng. 1875, t. 150; De Puydt, Les Orch.

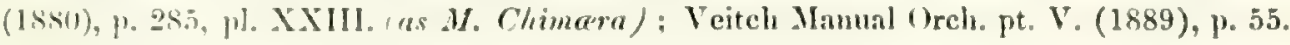

Leaf fi or i inches lomg, oblong-lanceolate, carinate at the back, margins waved, apex acutely tridenticulate, nurowing below in a slender grooved petiole, sheathed at the base, bright green.

Pofluncle $3 \mathrm{ol}^{\circ}+$ inches long, tercte, slender, lateral or descending from the base of the petiole, juinted. with a sheathing luact at each joint, dull reddish-green; flowering bract nearly $\frac{1}{2}$ inch long, aphulate. shenthing below, pale green, with one or two buds within at the base.

(W:ary abut $\neq$ inclı long, with six crenate wings, crimson and green.

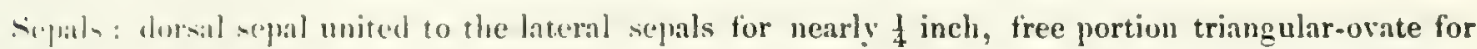
14 inch: latcral selals cohering for about s inch, trianular ovate, rounded beneath; all pale yellow, "overed with crimon spots and short stiff" hairs, the inner half of the lateral sepals nearly white, all with

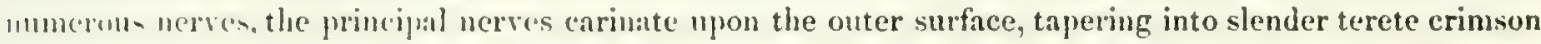
rails about 2 inches long.

l'etak abut f inch loug, oblong below, margins angled, apex bi-lobed, the outer lobe large and rombled, with mmerous small papillae in the centre, pale yellow spotted with rust-red.

Lip - arrely ! inch long, Heshy and deeply arooved at the base, and united to the foot of the column by a rery flexil)le hinge, anterior portion shell-like, spreading, margins converging, pure white tinged with pale vellow, with numerous raliating keels within.

('olum shorter than the petals. narrowly winged, apex denticulate, pale yellow tinged with red.

MASIELALAA NYCTERINA was discovered in 1872, by Gustar Wallis, near Frontino, in the Western Cordillen of Antioquia, at an elevation of $5-6,000$ feet. This region is also the habitat of M. ('himerere, MY. Carderi, and M. bella, as well as of

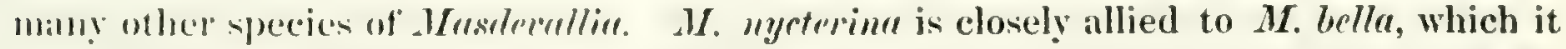
"-pecially resembles in the moed, shell-like lip, but it was at first mistaken for $\boldsymbol{M}$. r'himrorn by Hous. Linden, Who named and distributed Wallis's specimens as that -pecies. The coloured Plates published as $M$. ugcterinu more nearly resemble .\%. Traprefilio. showing in anch case the unrayed lip peculiar to that plant.

Explanation of l'bate. drawn from a plant at Newbattle Ibbey:

Fi.r. 1. petal, lip. and (a)lunn, in natural position ; - 1a, section of ovary ; - 2, petal, inner side ;2a. petal. sile :-3, lip ;-1. colum ; -4:1, apex of column; all enlarged. 


W 


\section{MASIDEVLLIA PUSILLA Rolfe.}

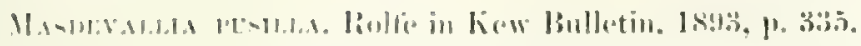

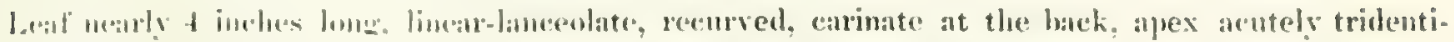

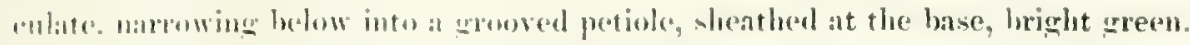

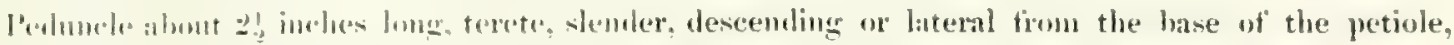
jointed. with a suall clowely sheathing bract at each juint, dull reddish-erreen; Howering bract $\frac{1}{2}$ inch

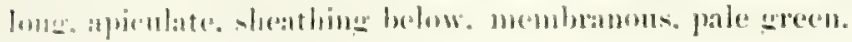

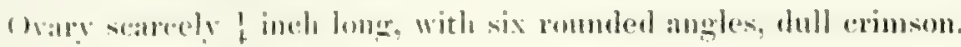

sepals: dorsal sepal anited to the lateral sepals for is inch, forming a narrow eup. free portions watc-trangular for about + inch, j-melved, the central nerve carinate; bateral sepals cohering for nearly I inth. rommled below, whome-ovate: all the sepals dull yellowish-white spotted with crimson,

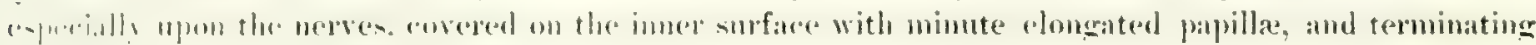

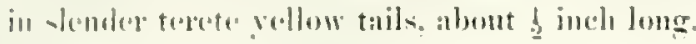

l'etals verg minute. oblong. with small angles upon the margins, apex bi-bobed and romded, with minute papillar hetweon the lobes, pale vellow spottod with rust-red.

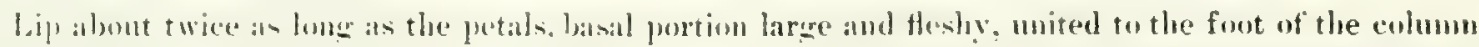
hy a theshle hinge. deeply hollowed in the centre. the anterior portion shell-like, with three central keels, very minute. palc yollow, with pink spots.

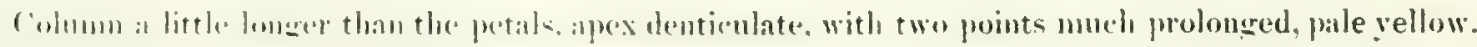

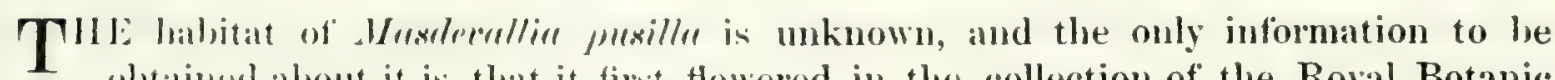
obsaind about it is, that it first fowered in the collection of the Royal Botanic Gardens at Dublin, in 1s91, and was sent ly Mr. F. W. Moore to Kew, where it was named and denclibed ly Mr. R. A. Rolfe. It is chiefy interesting as the smallest known yeeies of the surenlobiute, the tiny lip), petals, and other organs, showing in miniatme all the curious structural peculiarites of its larger allies.

Explanaton of l'lte. drawn from a plant in the Royal Botanic Garlens, (ilasnevin, I)ublin :

fig. 1. petal. lip. snd columm, in natural position ; - la, section of ovary ;-2, petal, imer side ;-

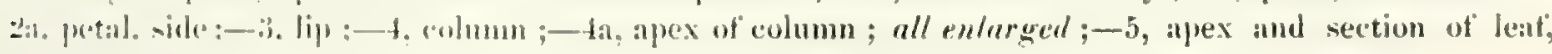
melumal size? 




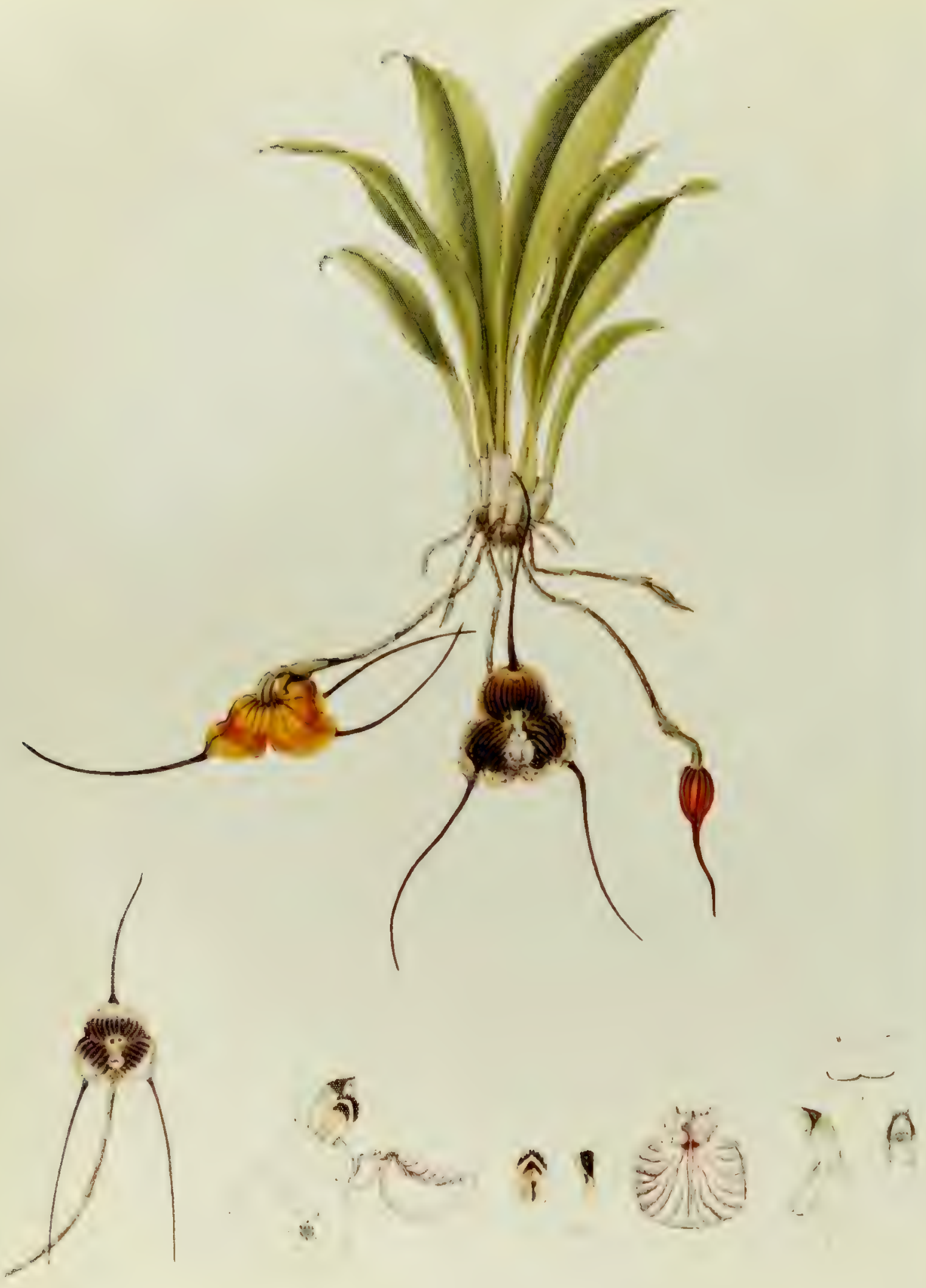




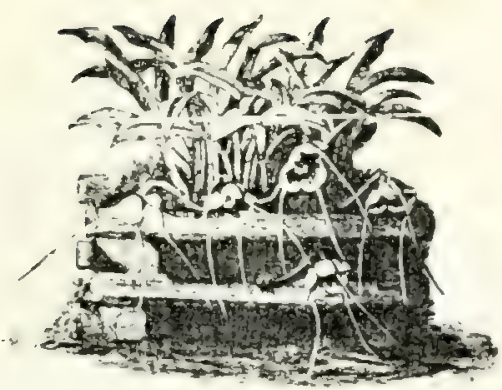

\section{MASDEVALLIA RADIOSA Rchb. f.}

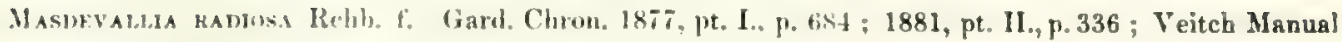
Orch.pt. V. (]xist), p. 59.

Leaf 5 or 6 inches long and about 3 inch broad, oblong-lanceolate, margins waved, apex acutely tridenticulate, narrowing helow into a slender petiole, sheatled at the base, bright green.

l'oduncle whont 4 inches long, terete, lateral or descending from the base of the petiole, with mumerous shesthing bracts, dull purplisl-green, 2 or 3-flowered, the flowers expanding in succession; flow'ring laract s inch long, owate-oblong, apiculate, sheathing below, dull green.

War: I inch loner, with six rounded angles, pale green.

Seprals all colsering for about buch, forming a wide slallow cup, gibbous below, free portions broadly wnl. cuncave, with numerous nerves, the central nerves carinate at the back, inner surface ochrevellow dorfed and streaked with dark purple and covered with small purple papilla, outer surface smooth, t: wи or apricot yellow, all terminating in slender tapering dark purple tails two inches long.

l'etals about i, inch long, oblong, angled at the margin, apex cleft into two wings, with numerous dark purple papillae within the cleft, ochre-vellow, with one or two dark purple spots.

Lip grooved and fleshy at the hase and united to the foot of the column by a flexible hinge, dilated into a broad shell.like lohe. white tingred with pate pink, with mumerous radiating keels within the shell.

Colum ahort and stout, very narrowly winged, pale pink below, green or paje yellow abore, with a liroad band of purple. aljex denticulate.

TMll: only hnown habitat of $M$. molioge is near Frontino, in Antioquia, where it was discovered hy Gustav Wallis in 1873, at an elevation of 8,000 feet. Living plants were sout ly him to Jesis. Veitch, in whose collection Professor Reichenbach first saw the flowers in 1876 .

I small and less attractive varicty, apparently commoner in cultivation, is represented at Fig. 6 of the accompanying Plate. $M$. maliosa is closely allied to $M$. bella, M. ('matrumii and M. mycterim, which it resembles in the wide and shell-like, rather than sirecuite, lip.

Comsul Iselmam ads the following information :

1). rmbiusu iv unc of the rarest species known to me. In fitct. I bave only found it in one locality, viz.. in the ncighbourhuod of Frontino, in Intiuguia. It grows on trees, always on the trunks, not far from the eround, in very damp dense woods, at an elevation of 1,600 to 2,100 mètres $(5,200$ to' 6,835 feet). The ammal me:th temperature of this region ranges from $16^{\circ}$ to $18^{\circ} .5$ Centigrade (about $60^{\circ}$ to $70^{\circ}$ Fahrenheit), and there is a heave and constant minfill throughout almost the whole year. Only in Fobruary, March. and Ausust there is a surt interval of finer weather, but even during these months Phere are lut few diys entively without rim. In a wild state $M$, radiosa flowers in October and Siventier.

Explanation of Plate, drawn from a plant at Newhattle Sbbey:

Fiz. 1, pral. lip. and colmm, in natural proition;-1:1, nection of ovary;-2, petal, inner side ; -

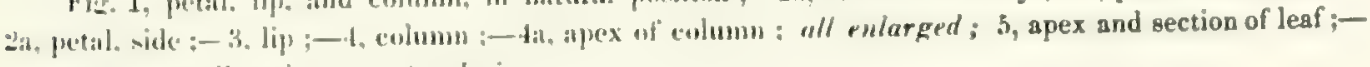
li, Howrer of mall variety : natural size. 




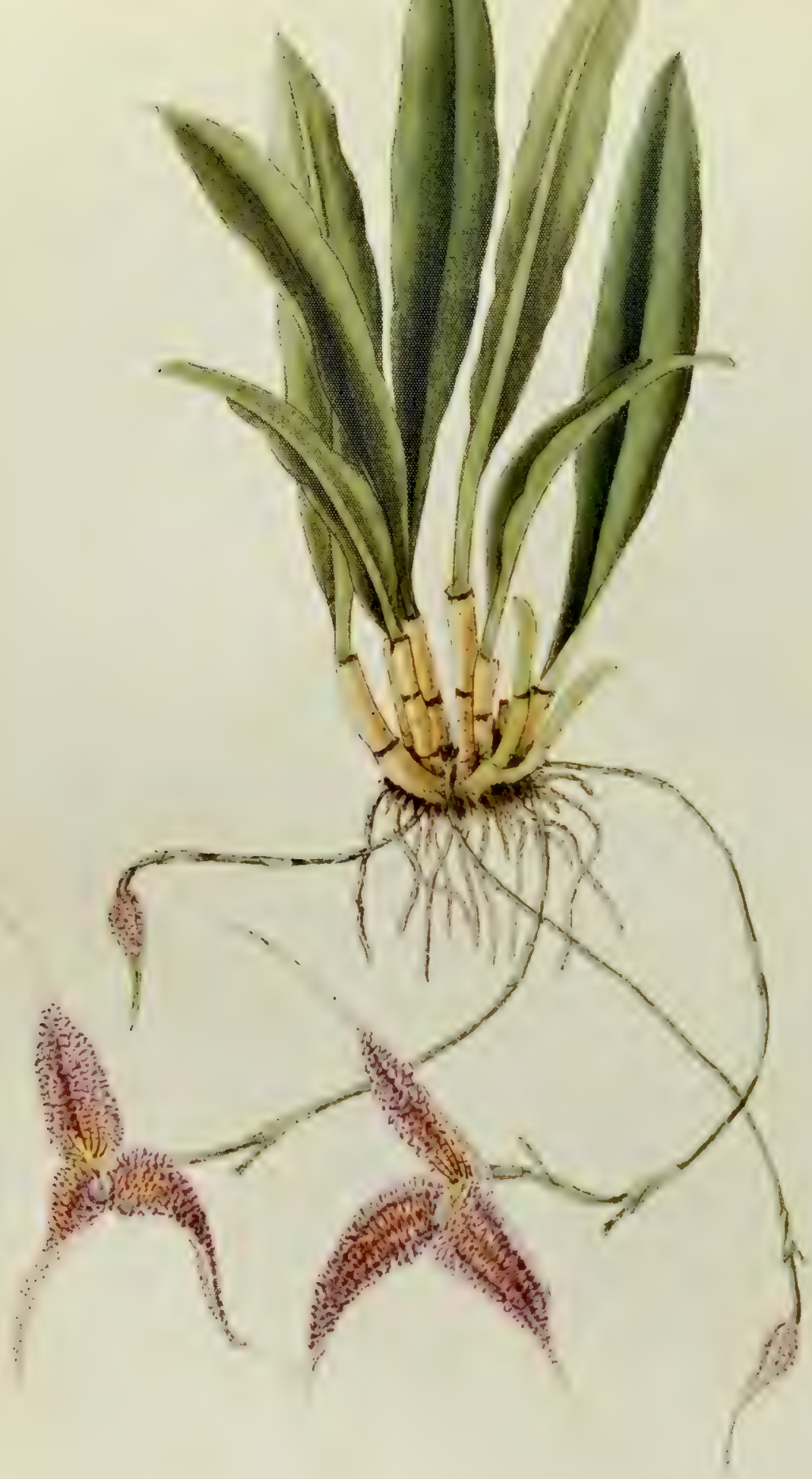

$$
\text { \& } \hat{i}^{*}
$$$$
=x
$$ 


\section{MASIOETALLIA TRINEMA Rchb. f.}

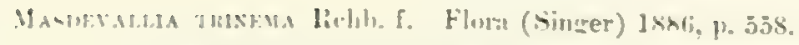

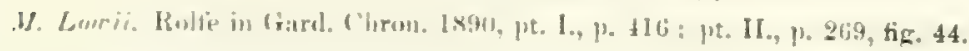

Leat if or F innles long, ollung-Lanceulate, carinate, acutely tridenticulate, margins waved, narrowing

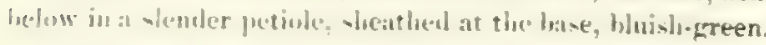

P'uluncle. 5 or 1 inches luns. terete, slemker, lateral or descending from the base of the petiole (rarely crect). 2 ur 3.Huwered. the Howers expandiug in succession, with numcrous sheathing bracts, pale

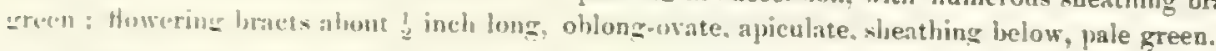

Wary tinch long, with sis rounderl angles, purplish-green.

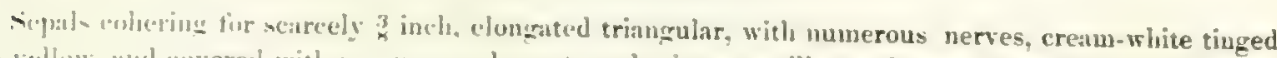
wiph vellow, ald covered with mave-purple spots and minute papille, each sepal tapering into a slender

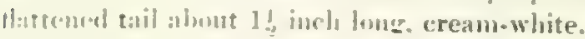

betal-almut I imels lung, thlong, the apex cleft into two lobes, with numerous minute dark purple fripillate brotween the holses, pale vellow, with a central streak and blotch of dark purple.

bip Jomer than the petith, erouved at the base and united to the foot of the column by a flexihle hims: flo.hy. with prominent central keels and uinute radiating lateral ones, flattened, scarcely hollow, manve-purple: with darker rayss and a few spots.

('uhmu a little Junger than the pretals, terete, urrowly winged, apex denticulate, pale yellow.

I'J in an the anthority of Comsul Lehmann-who has had the advantage of examining

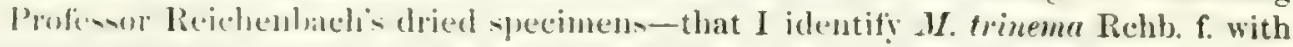
11. Lam if of Rolfe. The name of the original dincoverer of this species is unknown, and un indication of its habiat, beyond the words "Nor" Gran." is given in Reichenbachis deseription, written in 1886 ;

The phat is still very ne, the three or four specinens in cultivation having all bern divided from one small piece imported from Catea among a number of Orchids,

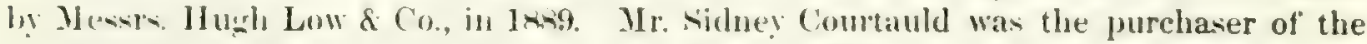
ne"w plant, and it first fowered in his collection in 18.0 . In a wild state the slender flower-stalks are sometimes ujright, hut more usually they are latteral, or descending in graceful curves through the moss which covers the roots of the plant.

fomsul Lehmam has found this species in the following locality:

Mresternllin trinema vecupies a very small range of the western mountains in the north of the ("auca aud of 11 intern Antioyuia, in ("olumbia. I first found it in 1883 on the Cordillera de Belalcazar, hetwern the tums of Cartagu and supin in the Cauca, and afterwards at Frontino and Ell Yarumal in the west and morth-west of Autioguia. It arows on trees in thick damp woous at an elevation of 1,500 to

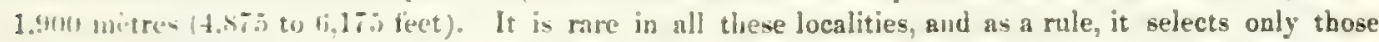

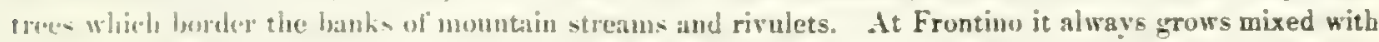
flants ul .U. Peris/erin, M. milificn, and M. Curleri. The climate of its habitat is similar to that in which .1. Chimcers thrives, the temperature being about $1^{\circ}$ Centigrade higher.

Plere is a marked variation in tlu colour of the flowers. At Frontino and El Yarumal the sepals are dull velluwiali-whitu. dor-cely cross-blotched witl an opapue brown. In the plants found on the mountains of liclaleazar the fluwers are larger, and the sepals are creany-white, marked with lilac-brown to only iwo-thirds of their length, the puints renaining pure white.

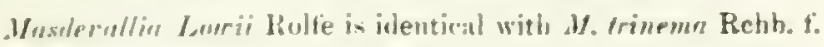

Fixplanatiun of Pllafe:

Fis. 1, petal, lip̣, and columu, in matural pusition ;-1a, section of ovary ; - 2, petal, inner side ;-

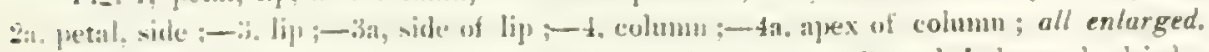

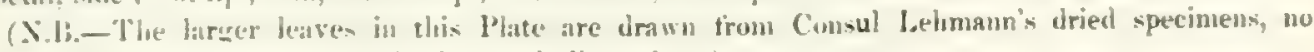
enlivated flatut having as yet attained to such diunsojuns.) 




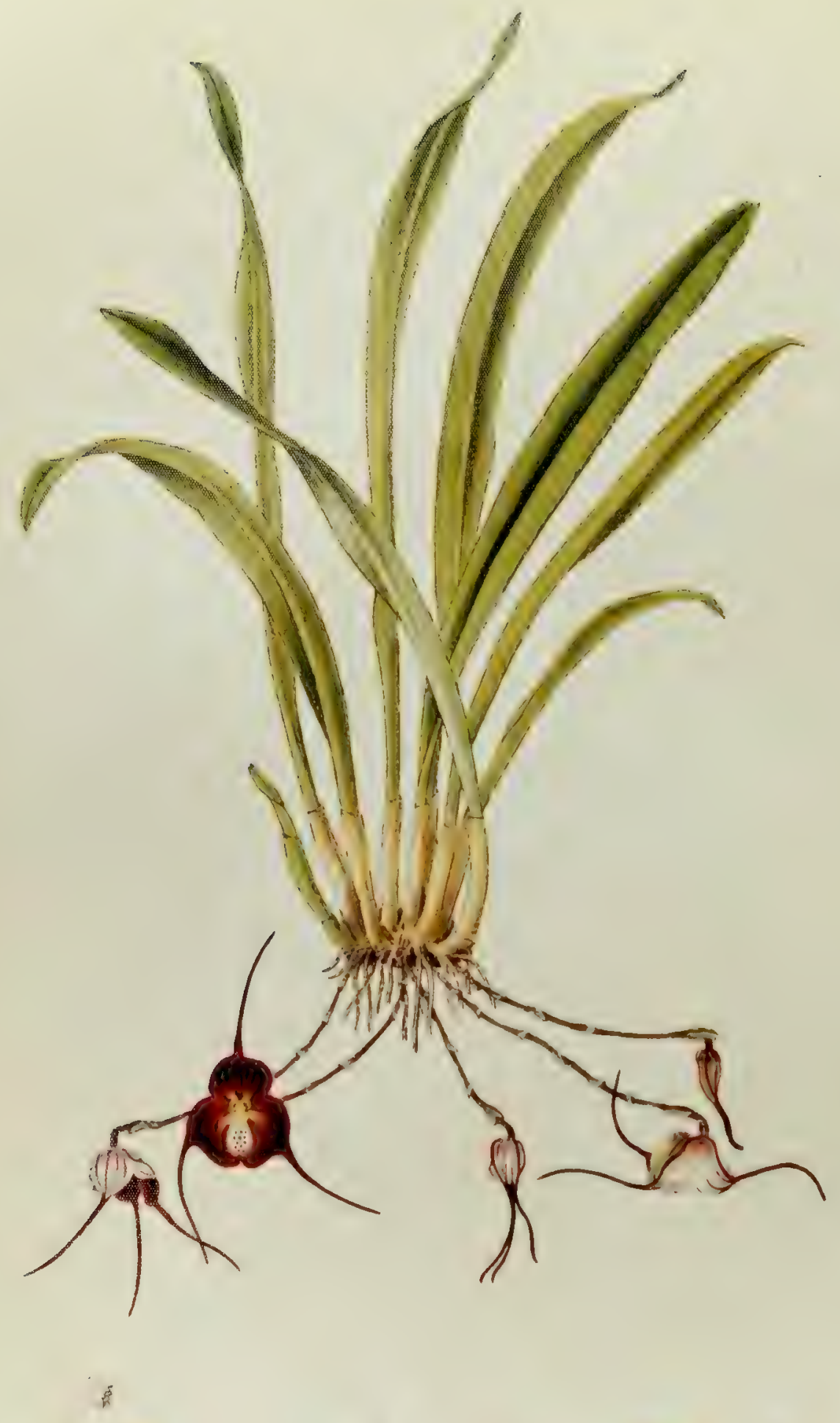

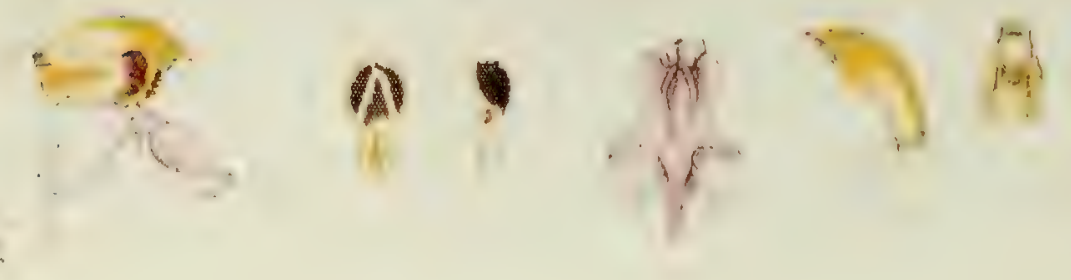




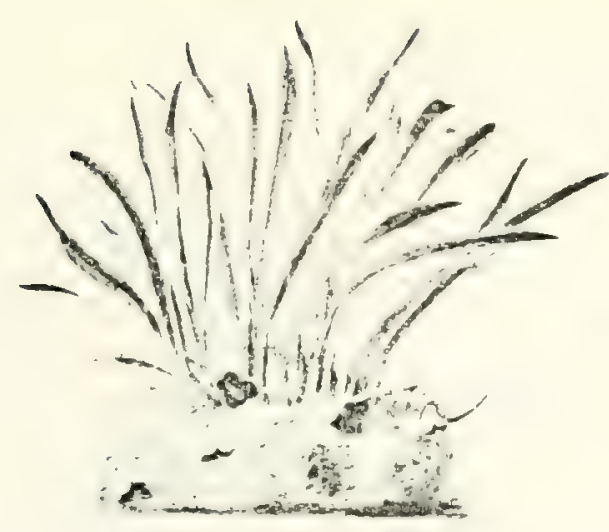

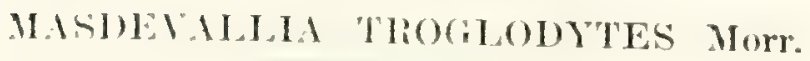

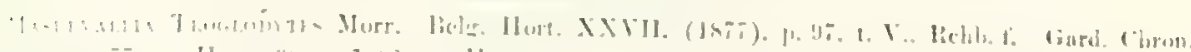

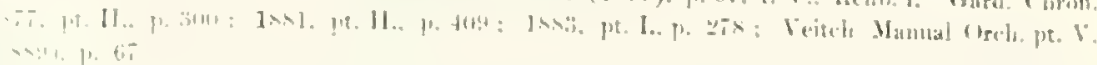

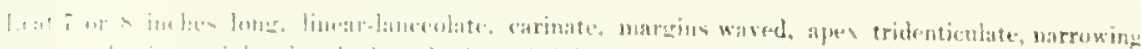

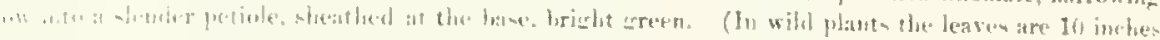
1 lowe ines

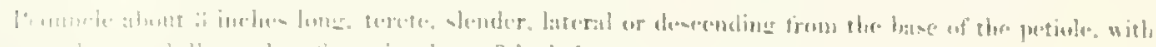

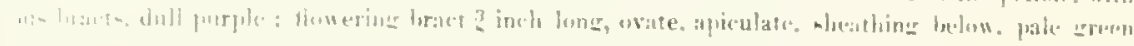

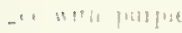

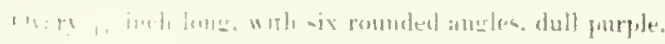

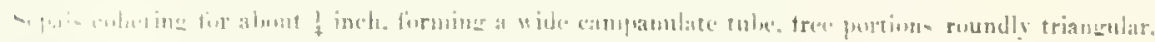

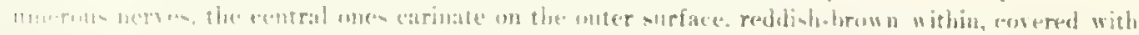

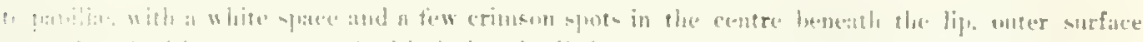

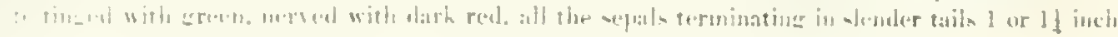
- . e.t: rent

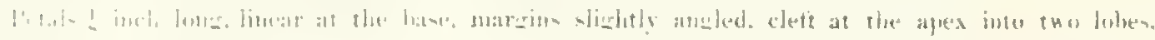

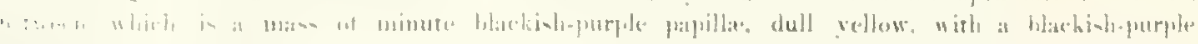

- 1 - 018 - -10.

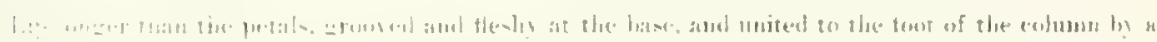

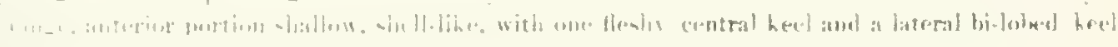

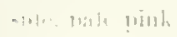

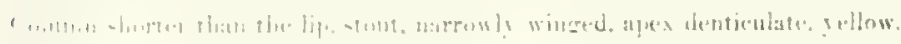

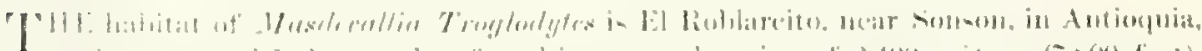

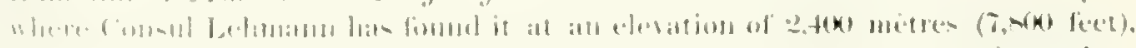

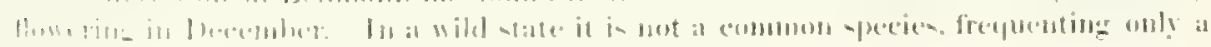

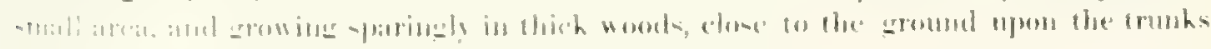
(1) $11, \ldots$

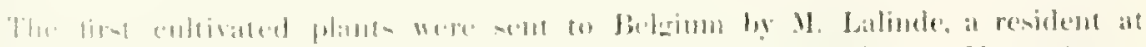

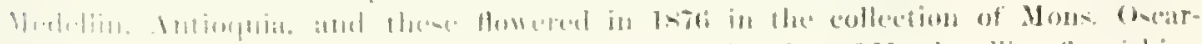

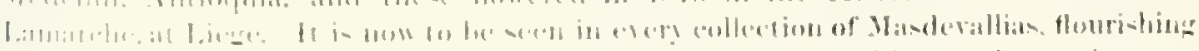

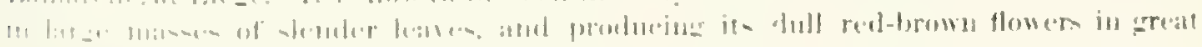
$1+1,1,1$,

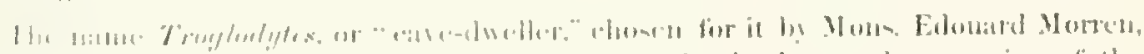

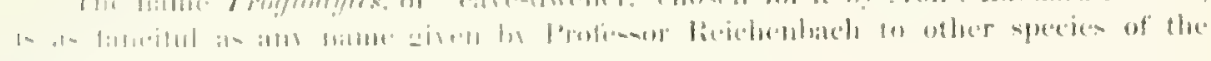

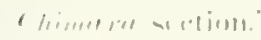

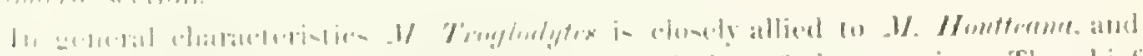

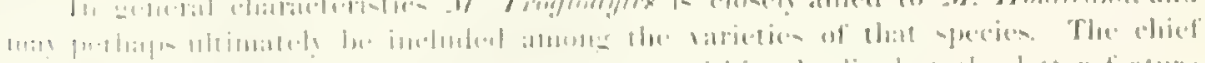

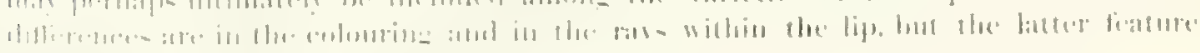

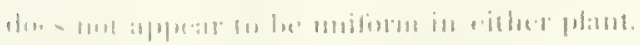

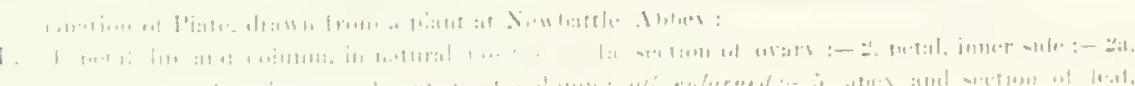






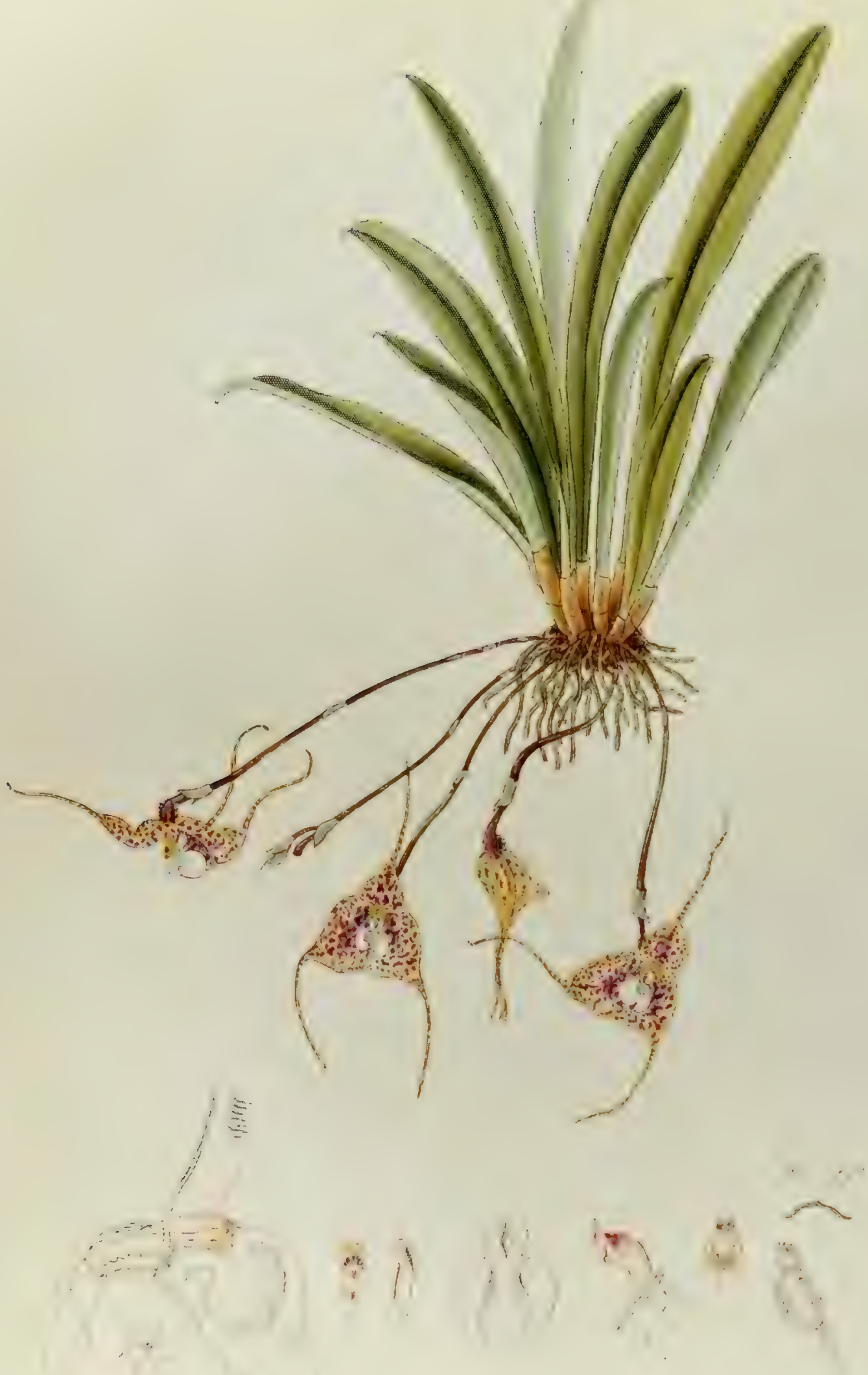




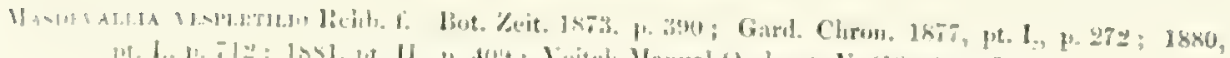

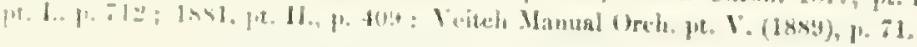

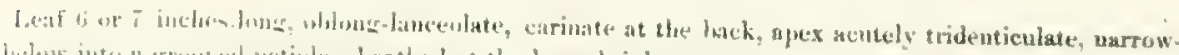

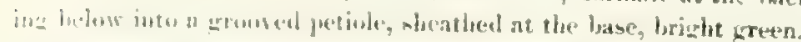

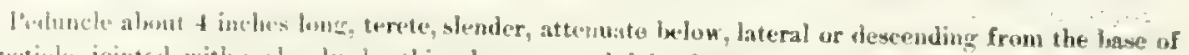

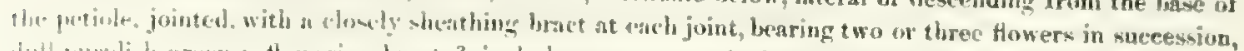

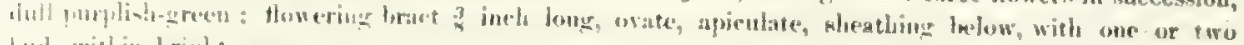

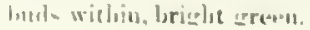

Wary I iucls fung, with six crentate wingw, preen and crimsm.

Sepale: durail sepal united to the lateral sepals for alout inch, forming an open cup, free portion

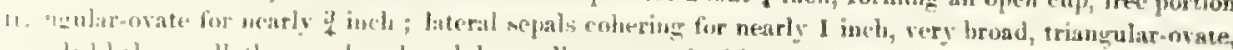

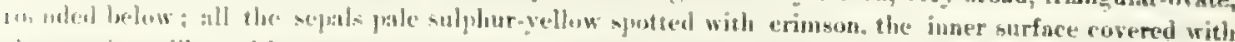

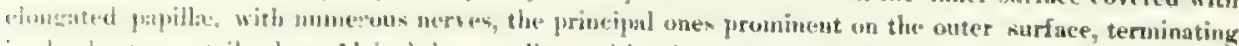

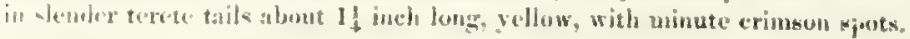

l'etals sourcely I inch long, bhinng, algex bilobed, with a mass of miunte reddish papulla between the

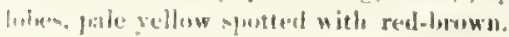

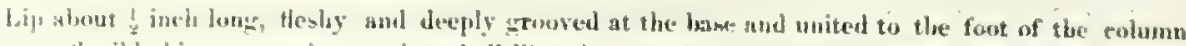

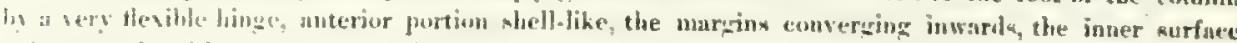
'plite-mastl. without rays, jure white.

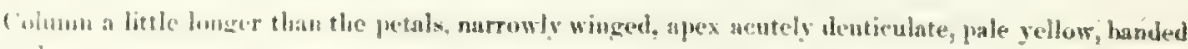
with reil

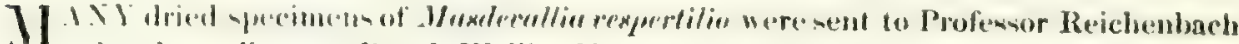
ly the collector labegl, Wallis, Chestertm and Patin, from the Valley of the

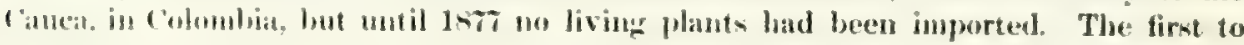
Hower were in the collection of Sir Trevor Lawrence.

The general chanceteristico of the flower are constant and distince, and the structure of the lip alome woukl attice to identify the species. This organ is remarkable for the

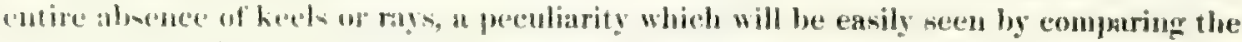

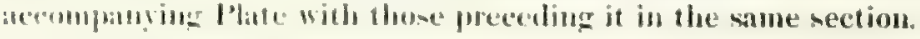

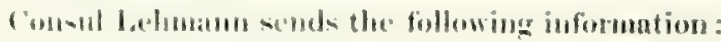

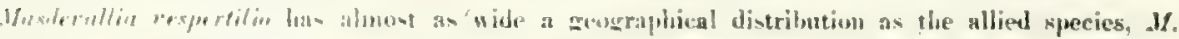

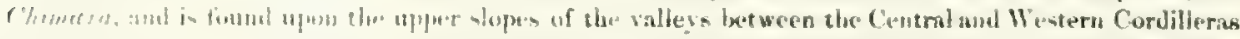

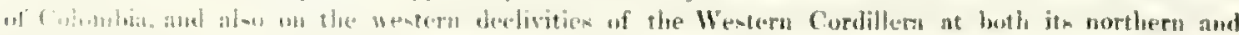

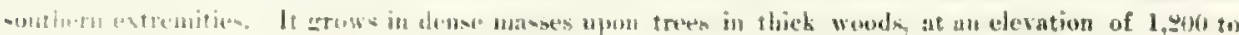
1.

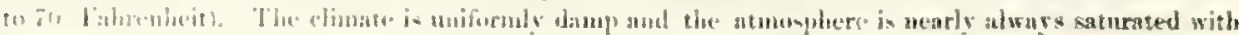
111., e+111,

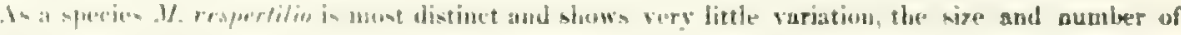

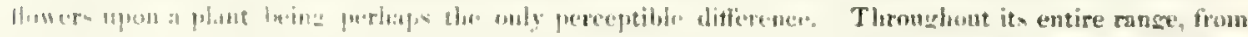

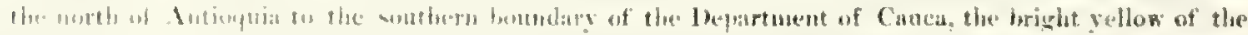

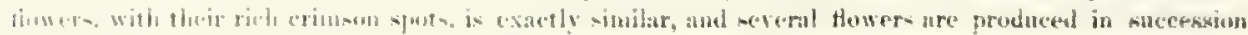

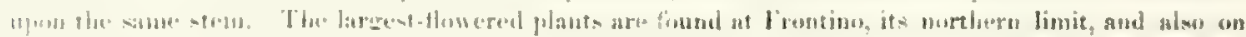

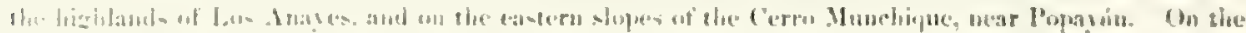

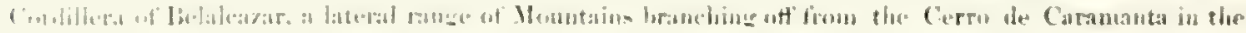

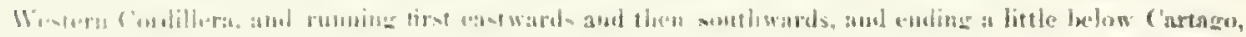

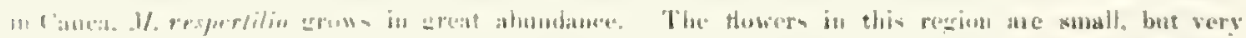

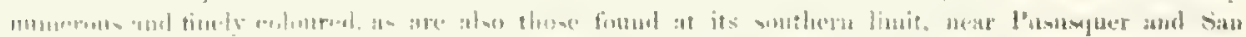

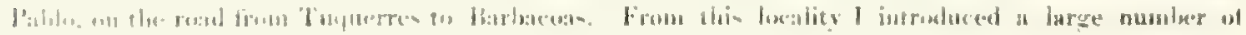

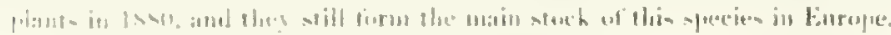

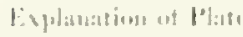

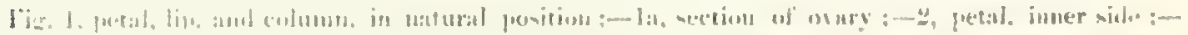

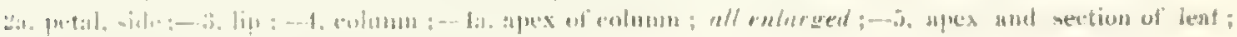

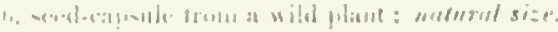





\section{SEC"TION XII.}

\section{SAITATRI'TS Rohb.}

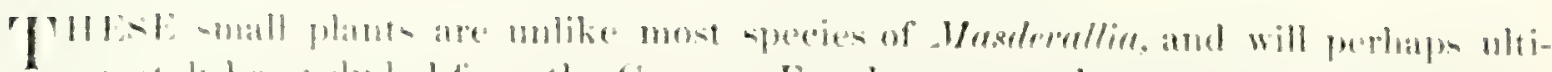

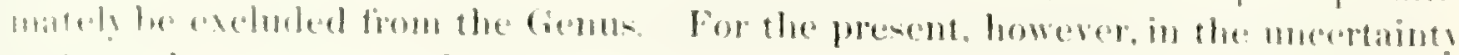

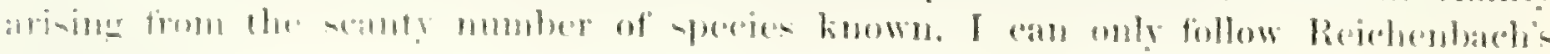
relan-ifications.

$\because$ specien figureal:

Masdeallia obrieniatua Rolfe.

-imula licelw. t:

Sint in coultivertion:

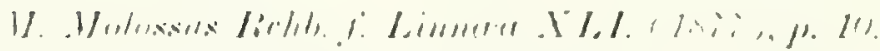

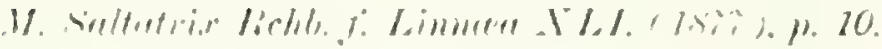





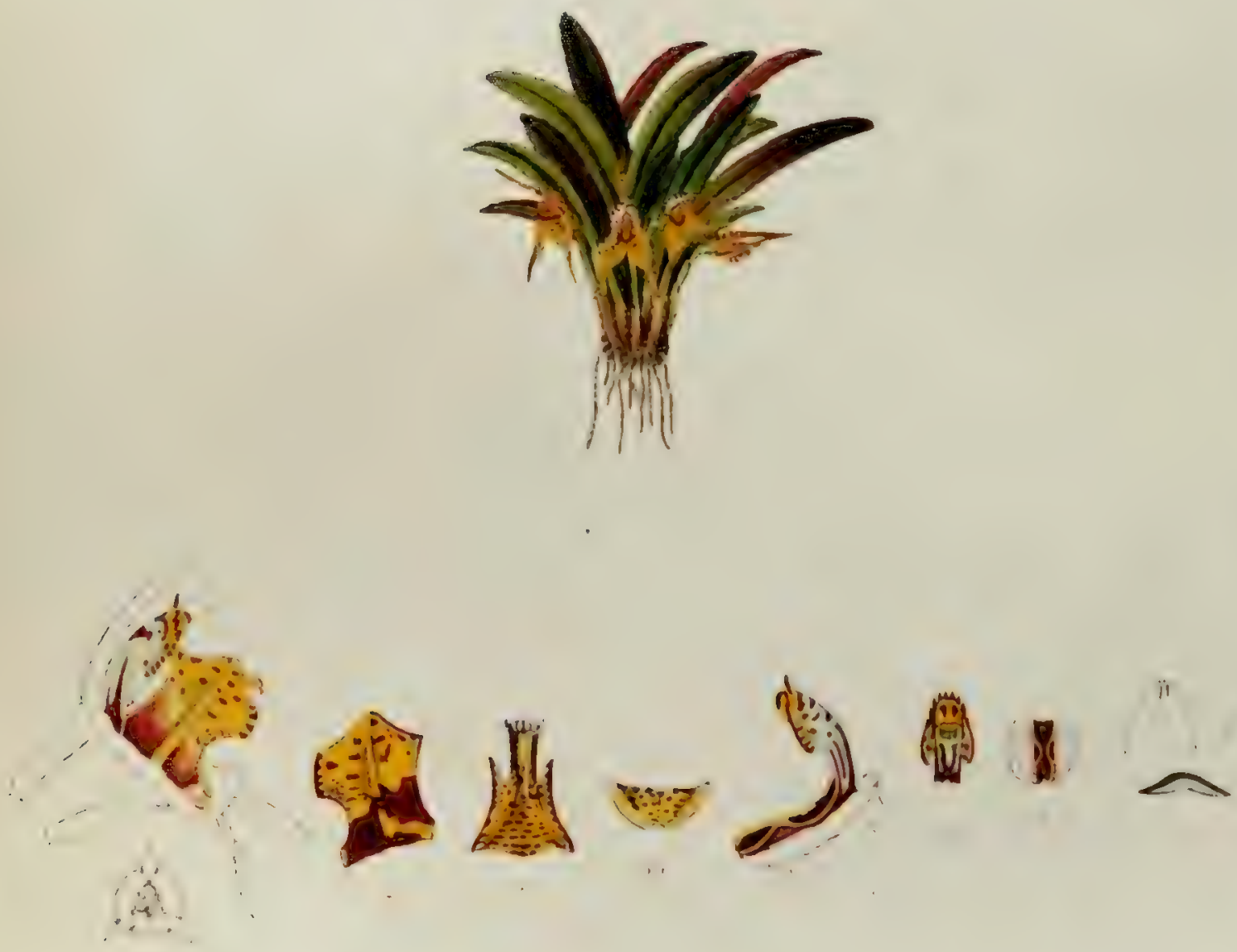


\section{MASIEVALIA O'BRIEXIANA Rolfe.}

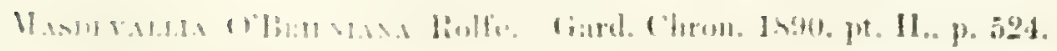

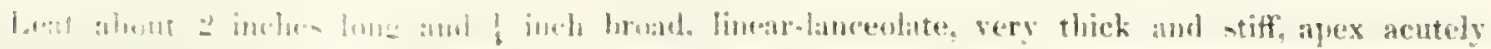

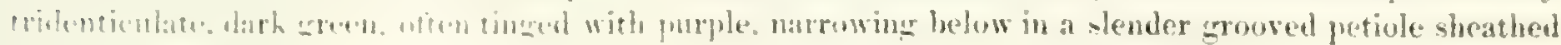
sit the lians.

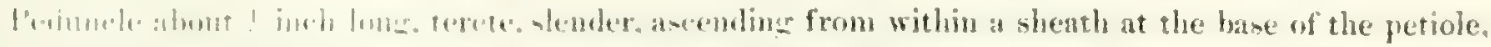

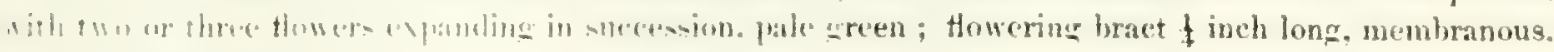
apromiate. rlull hrown.

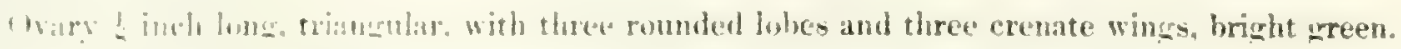

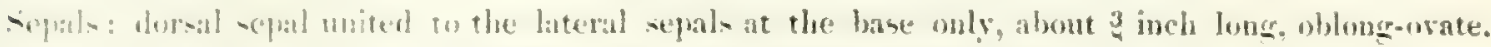

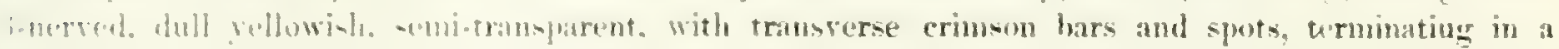
- lender pubted tail f inde lone orallec-vellow, with minute crimson spots; lateral sepals colering for

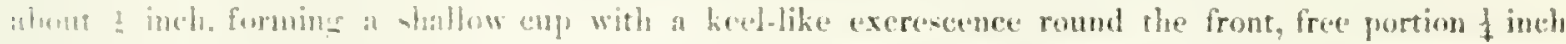

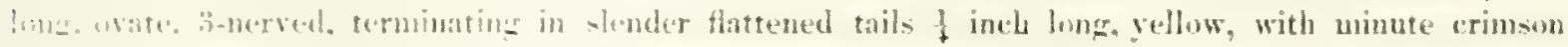

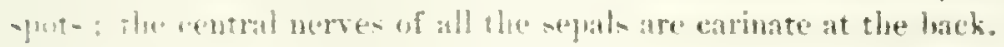

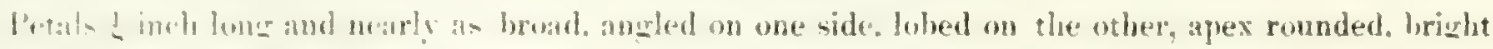

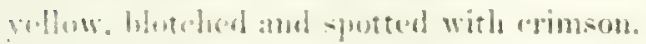

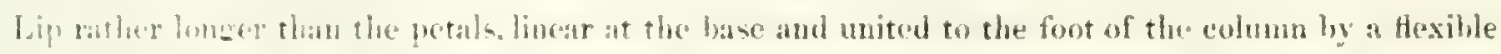
linse. anterior purion rers brond. with two horn-like prejections and two prominent angular lobes, apex rettered, brich yollow. with sumerums crimson spots.

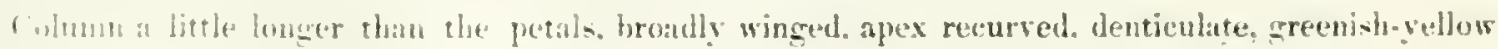
inofent with rimson, the font rich crimson, whth two curved lomgitudinal hright vellow keels.

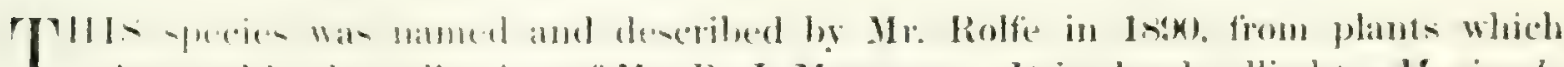

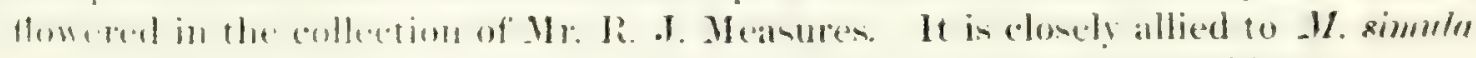

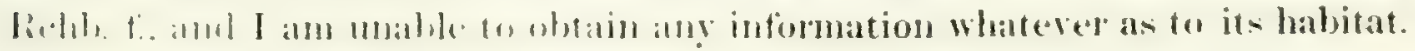

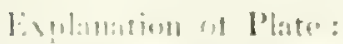

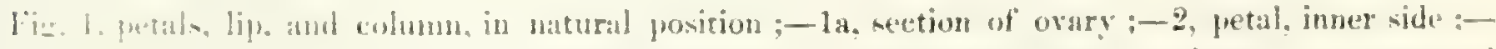

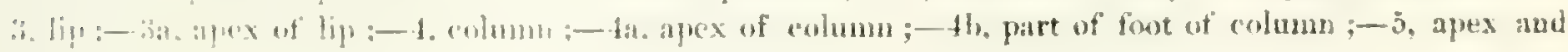
-reption of hath: all enluresed. 



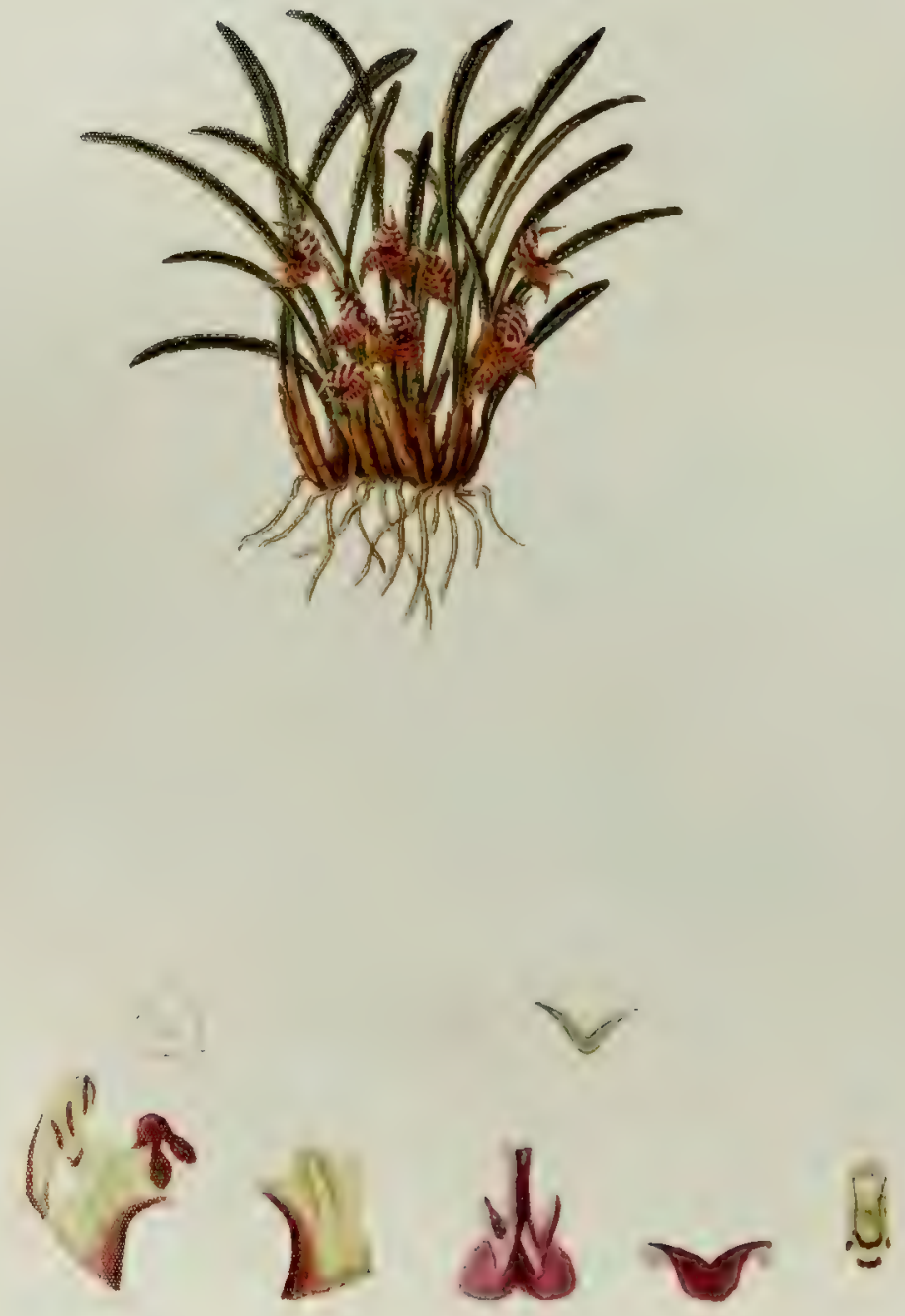


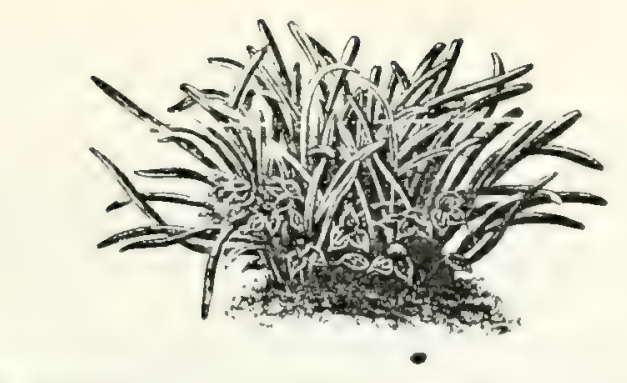

MASDEVALLIA SIMULA Rchb. f.

Masnevalzia stmela Rchb. f. Gard. Chron. 1875 , pt. I., p. $8 ; 1881$, pt. II., p. 409.

Leaf 1 to $2 \frac{3}{2}$ inches lons, and $\frac{1}{n}$ inch broad, linear, fleshy, curved, tridenticulate, dull green tinged with jurple and covered with minute excrescences, narrowing below into a slender petiole, dark green,
shenthed at the base.

Peduncle about 3 inch long, terete, 2 or 3 -flowered, each flower fading befure the expansion of the next, ancending from near the base of the petiole, witls minute apiculate bracts.

(Wary it inch long, triangular, with six grooves.

Sepals: dorsal sepal united to the lateral sepals very little beyond the base, about 1 inch long, aronety keeled without. 3-nerved, cucullate, ovate-lanceolate, terminating in a blunt joint, semi-traneparent, greenish, barred with small tmasverse crimson spots; lateral sepals cohering for nearly f inch, gibbous below; with a dark crimson excrescence within beneath the lip, 3-nerved, orate-lanceolate, terminating in marrow points, yellowish green, with suall transwerse crimson spots.

Petals scarcely $\frac{1}{3}$ incli long, and about half as broad, triangular at the apex, strongly angled on the anterior margin, green and crimson.

Lij rather more than $\frac{1}{5}$ inch long, linear at the base, then with two proninent angular lobes, anterior fortion corrate, with two horn-like projections, margin minutely crenate, apex much reflexed, dark crimson-purple.

Column ${ }_{n}^{1}$ inch long, with triangular wings, apex minutely denticulate, green edged and spotted with erimson.

$\mathrm{M}$

ASUEVALLIA SIMULA was discovered in 1874, by Chesterton, while collecting in Colombia for Messis. Veitch. Its small size and the inconspicuous colour of its flowers, wrowing half hidden in moss at the base of the leaves, make it of little interest cscept to botanists, but the curious and unusual structure of the petals and lip will be fouml to repay careful examination. In cultivation the time of flowering is from April (0) July, during which time several flowers appear in succession from the same stem. The carce locillities in which this little plant is to be found have not hitherto been made generally known, and are given as follows by Consul Lehmann:

This peculiar and very variable species, in my opinion more a Pleurothallis than a Menselerellin, has an extensive distribution over the Andes of Colombia and Ecuador. In the north it extends as far as the northern parts of Antioquia, growing abundantly on the highlands of Santa Rosil and Carolina, at an elevation of $2,000-2,600$ metres $(6,500-8,450$ fect $)$. In the south it has been met with as far as the central and eastern districts of the province of Azuay or Cuenca, at the same elevation as in Antioquia. In the vicinity of Poparán it grows abundantly at an eleration of 1,800 mètres ( 5,850 feet), while on the Nlto del Mojanda, between Otabalo and Malchingui, it is equally common af $: 3,000)$ mitres $(9,750$ feet). It occurs on the western declivities of the central and Western Ancles, expecially on those of the Andes of Quito, and extends from 7 . $\mathrm{X}$. lat. to $3 \mathrm{~s}$. lat. The temperature in which this plant thrives varies greatly according to the clevation of the locality, the lowest being $9^{\circ}$ and the highest $17^{\circ} .5$ Centigrade $\left(48^{\circ}\right.$ to (63 Filırenheit). 

There appears to be some doubt as to whether all the different varieties betong to the same species. Up to this moment $I$ have not been able to detect any structural difference,-merely a larger or smaller development in any plant from the different localities. The form represented in the accompanying plate is a good medium development of the species, as it is found in the vicinity of Aguadas and Sonson, and other parts of Antioquia. The smallest form is met with near Poparán and on the Alto del Mojanda, near Quito, the leaves seldom exceeding 3 centimitres (about $1 /$ inch) in length. The largest form, the leaves of which attain a length of 16 or 18 centimetren (6:1 or 7 inches), grows on rocks and trees in the damp and shady woods on the western slopes of the Corazon mountains, near Quito, at an elevation of 2,000 to 2,400 metren (6,500 to 7,800 feet).

\section{F. C. Lemmaxx.}

Explanation of Plate, drawn from a plant at Newbattle Abbey:

Fig. 1, petal, lip, and column, in natural position;-1a, sectiou of ovary ; - 2, petal, inuer side ;3, lip ; -3a, apex of lip;-4, apex of column; -5, apex and section of leaf; all much enlarged. 



\title{
TRIANGULARES Rehb. f.
}

\author{
(ALAI) CALLF.J) ("ALUATH.)
}

THIs section includes numerous species allied to M. triangularis. Their chief chameteristics are, slender growth, the delicate membranous texture of the flowers, and in most cases, the shallowness of the tube and the great length of the tails.

\section{0 species figured:}

Masclevallia Arminii Rehb. f.

caudata Lindl. (=M. Shutfleworthii Rehl. fo)

Estriclie Relil). f.

Horibunda Lindl. (=M. Gulenttiuna Rich. et Gal., M. myriostigma Morren., et M. Limentuma Rich. et Gal.

hieroglyphica Rehl). f.

ionocharis Relıb. f:

triangularis Lindl.

uniffora Ruiz et Pav. (not in cultivations.)

Wayneriaua Rchb. f.

xanthina Rchb. f.

Not in cultiration:

M. expenns Rehb.j. Otia Bot. Hamb. (1878), p. 16.

hymenumthre líchb. f. Bomplanelia III. (1855), p. 225.

incequelis lichb. fi. Gurel. Chrm. 18\%4, pt. I., p. 3\%.

tricolur lichl. f. Gurd. Chron. 1882, pt. II., p. 102.

uniflora, (sep l'/ate.)

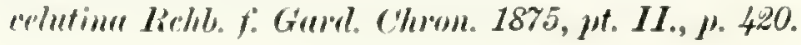





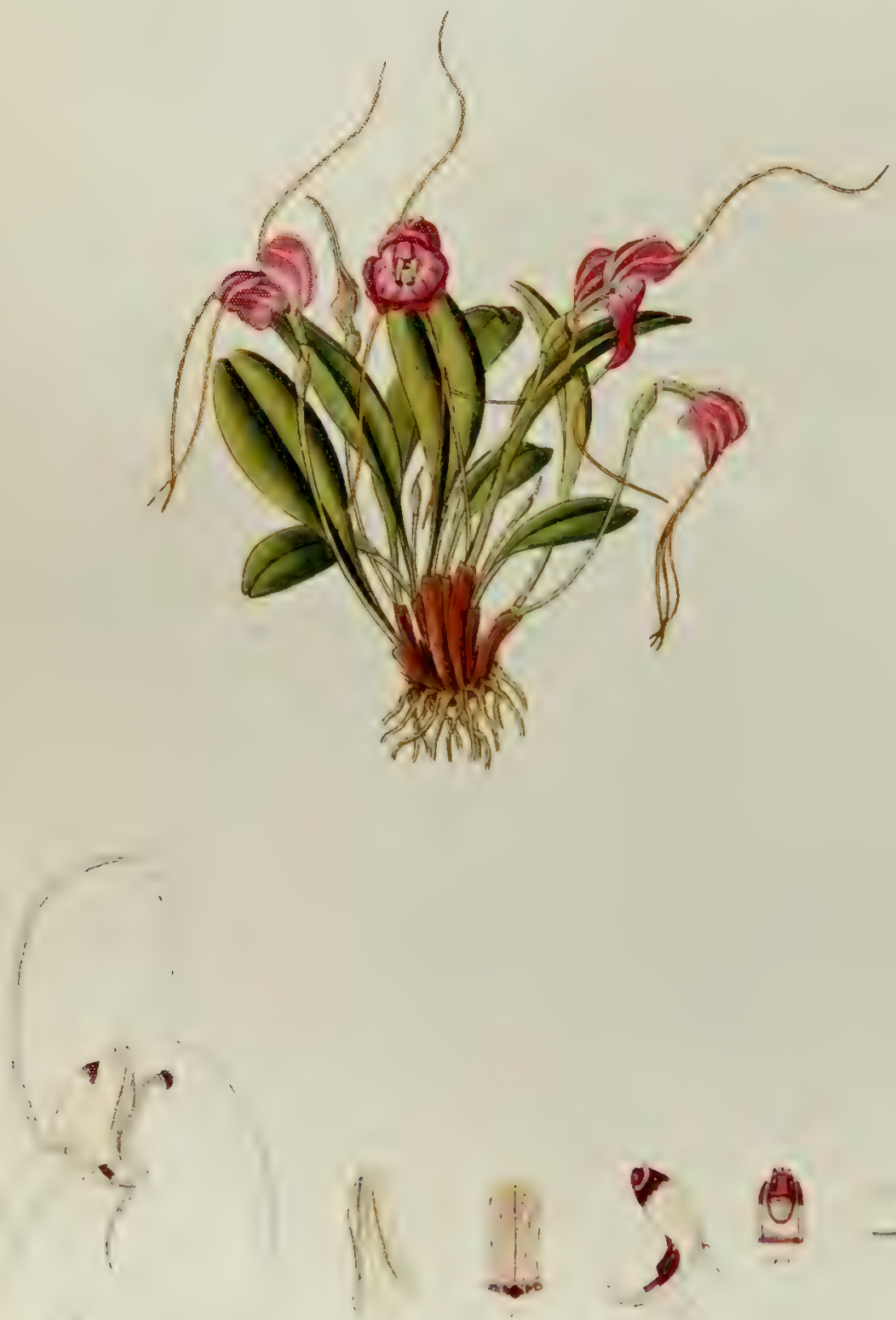


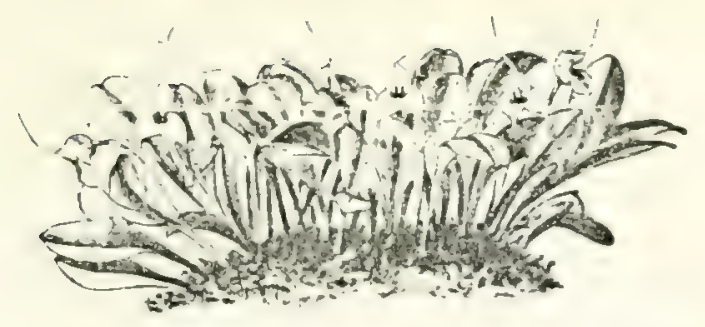

\section{IASDEVALLIA ARMINII Rchb. f.}

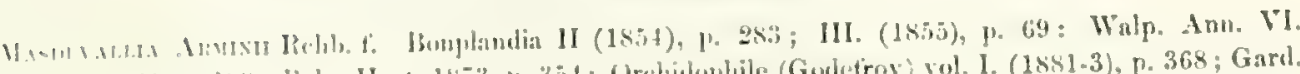

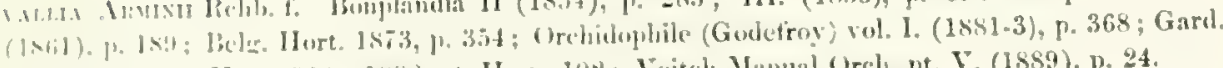

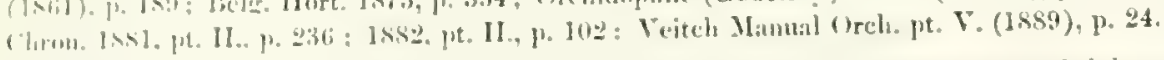

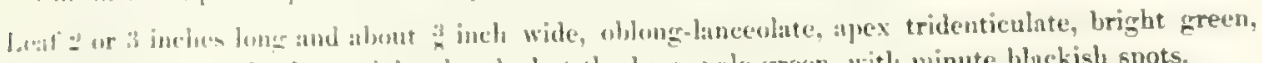

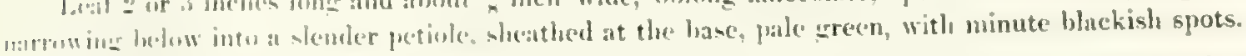

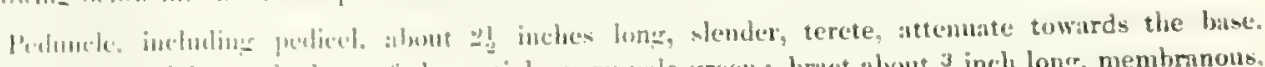

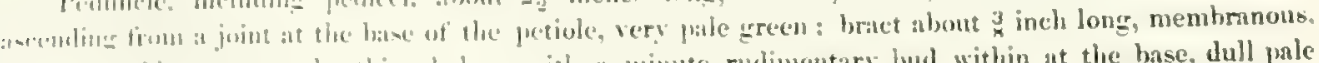

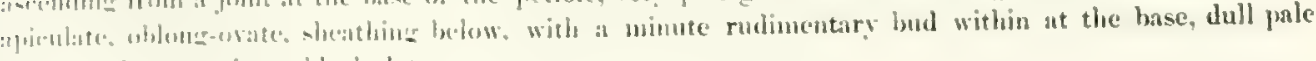

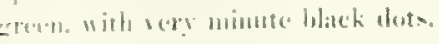
Alita.

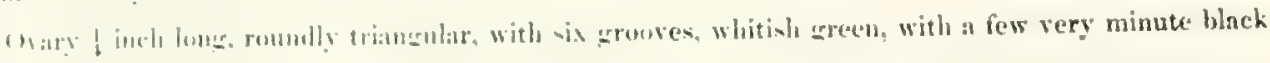

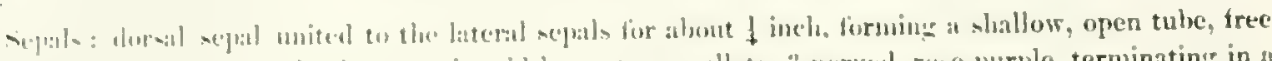

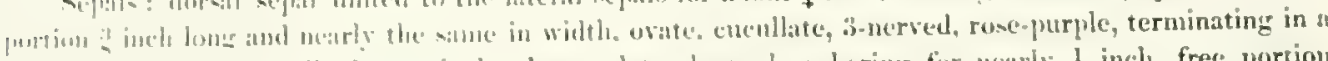

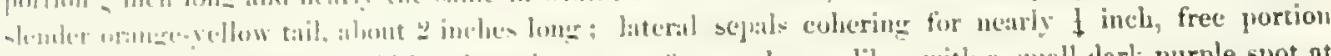

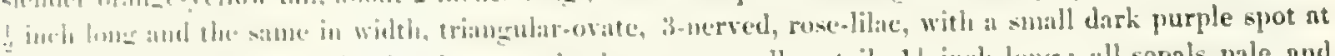

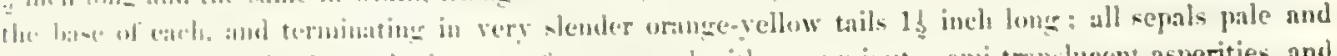

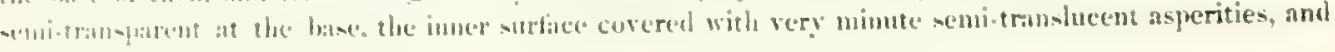

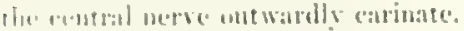

betal- wearly | incl, lome oblones narrowing towards the apes, with a brond keed and amgle on the

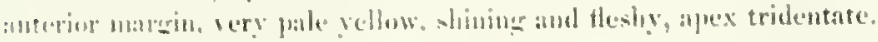

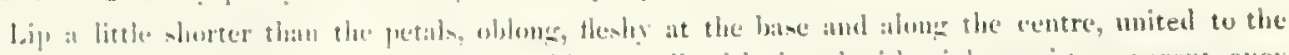

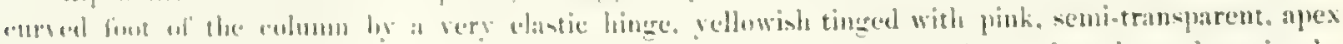

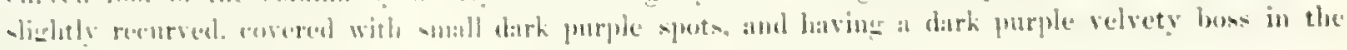
mentre

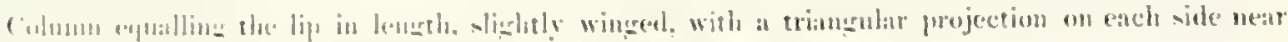

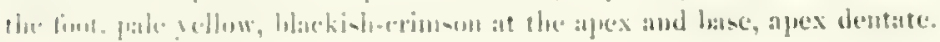

II

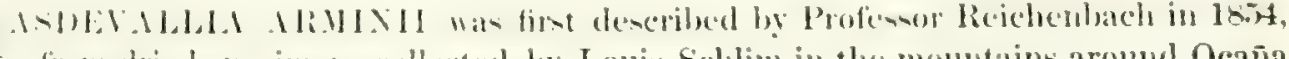

from dricel specincus colleded hy Lours Sehlim in the mountans around Ocaña and l'amploni, in the Province of Santander, Colombia. So date is assigned to his

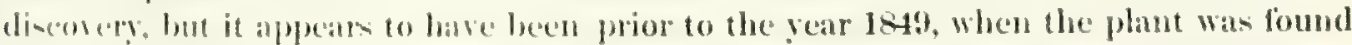

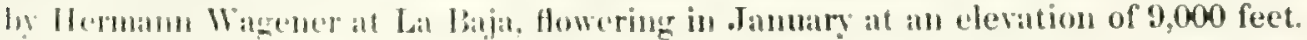

"l'he internal stucture of .M. Ammin difles from that of other species in the renathable projection upon cate side of the base of the column, shown at fig. 4 of the aceompanying l'ate. In the living flower this projection is closely surrounded, or emblaced, log the comed angle of the petal, and must be designed to serve some pur-

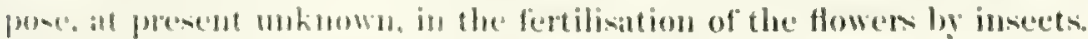

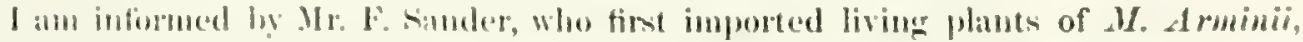

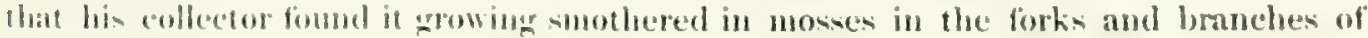
trees. on the wemern sopes of the Audes of Ecuador, the habitat of M. rosen.

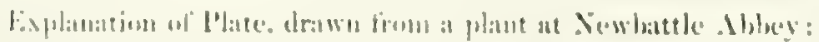

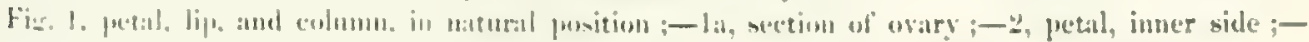

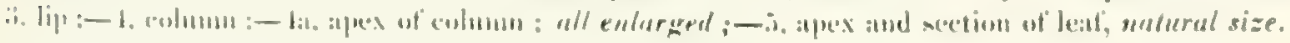






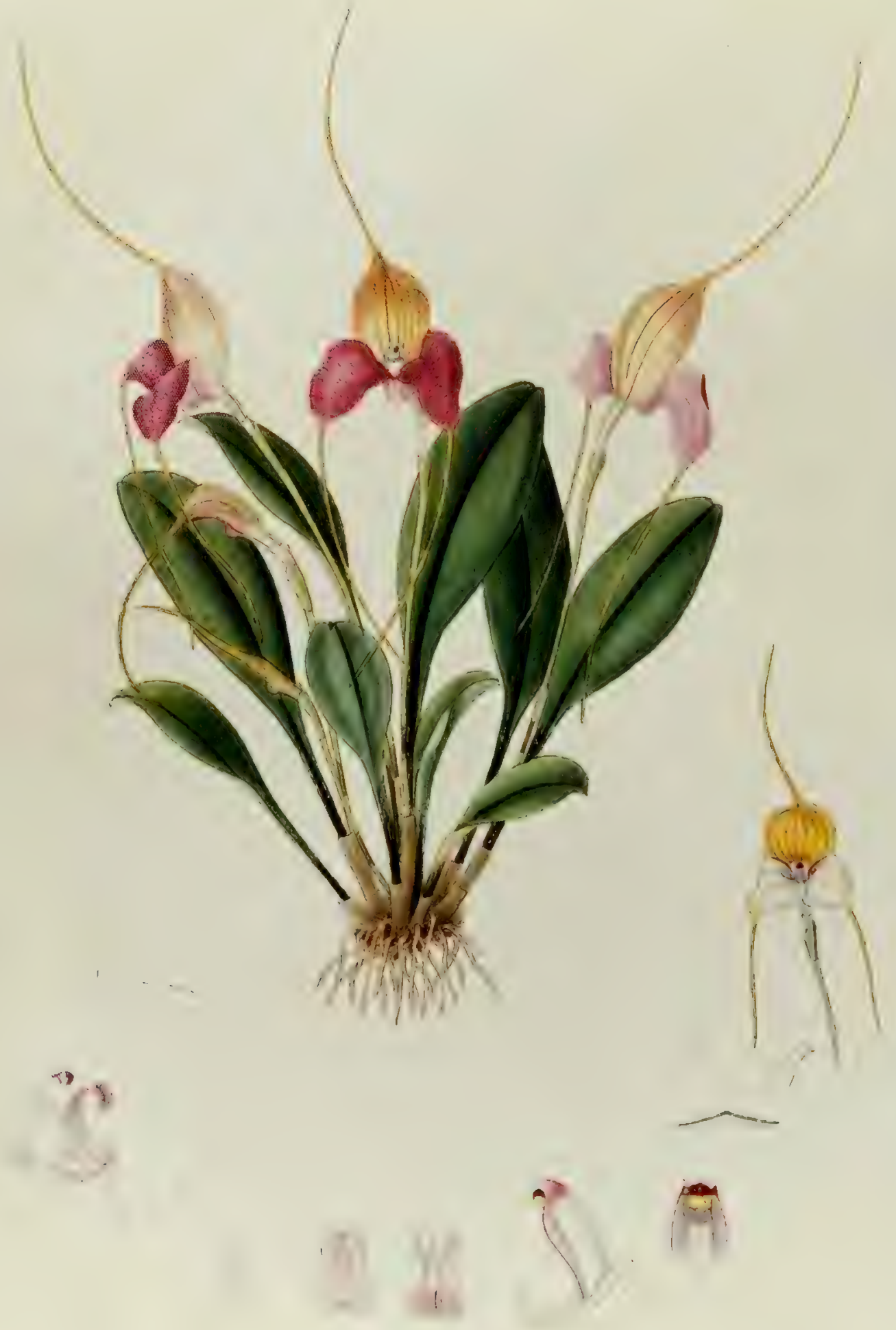



one by Dr. H. Kumten. of Berlin, drawn, he informs me, in its matre landitat-the mountains of Bograti-from freshly gathered flowers, and published in his splendis work

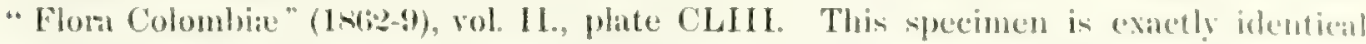

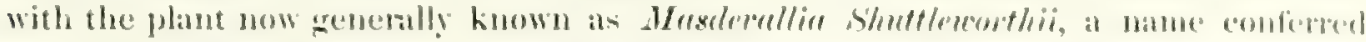

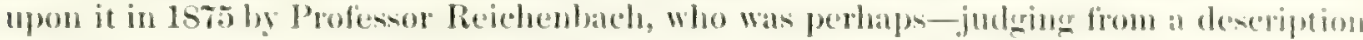

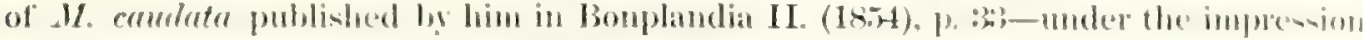
that the two were distinct species. He here deseribes the colour of the sepals as green and that of the tails volet, stating the habitat to be Caracas, a locality in which dhe true

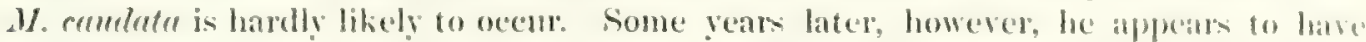

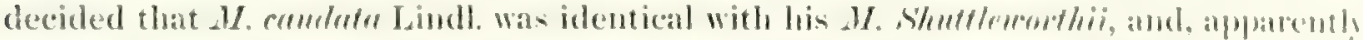

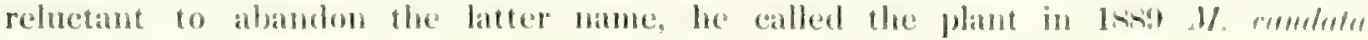
shuttlenerthii.

Wild plants frequently attain a greater size than those flowering in cultivation. specimens larger than that here represented having been found by Comsul Ledmann on

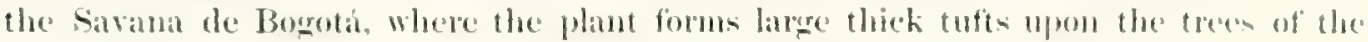
western slopes.

A variation ocem in individual phants in the number of the crinson stripes of the

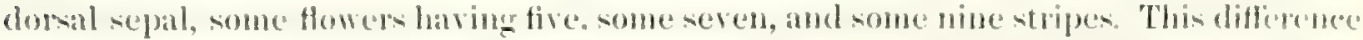
in not due to any varation in the number of the nerves, but to the bifureation or monhifureation, arencrally near the bated, of one of both of the two hateral nerves.

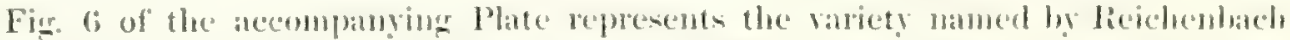
menthocorys-ychow-helmet-which appeared in $18 \mathrm{~s} 2$ in the collection of sir Trevor Isiwrence.

several hybrids have been raised between $M$. comblete and other species, of which

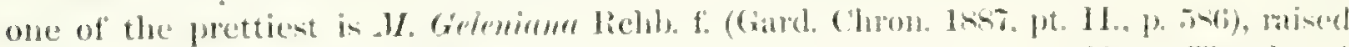

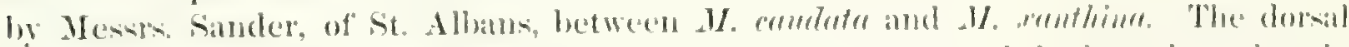
sepal is orange-yellow, with numerous small crimson spots, and the lateral sepbils palle? pink timged with yellow, and having some of the small trumberse -pots so romatsible in M. crembere. The tails are slender, about 3 inches bong, and bright orange-pellem.

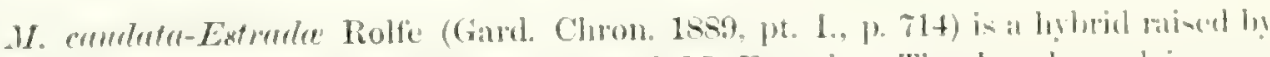

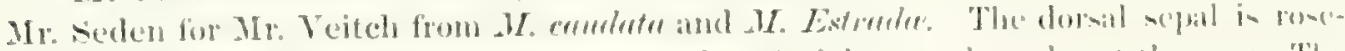
purple, yellowish at the base, the lateral sepals soft violet-purple, palce at the alded. The taiks are about 2 inches long, orange-yellow.

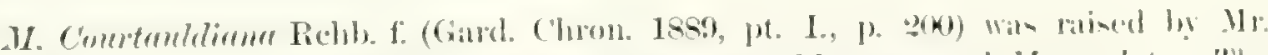

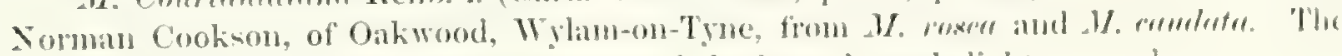

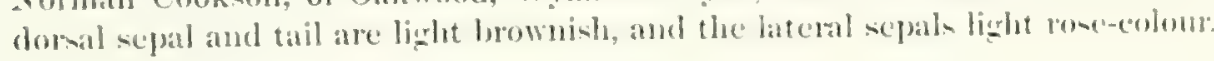

foncul Lelmann contrilutes the following information:

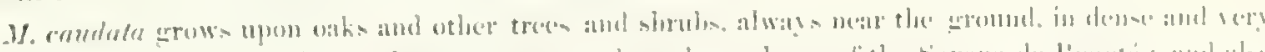

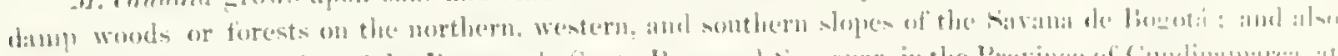

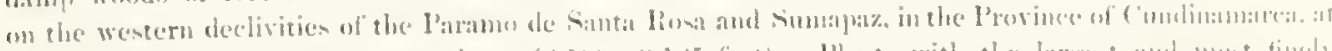

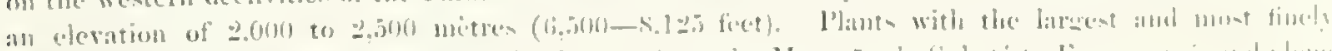

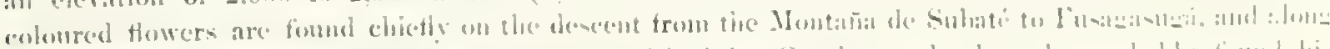

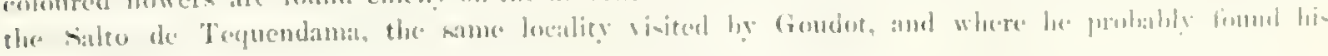
ynexintus.

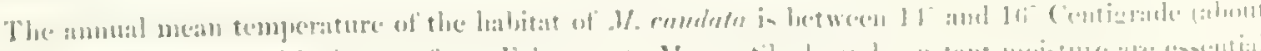

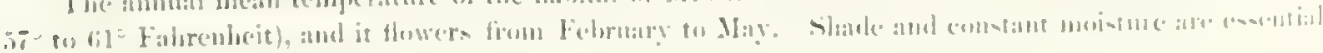
to the derelopment of this mpecies.

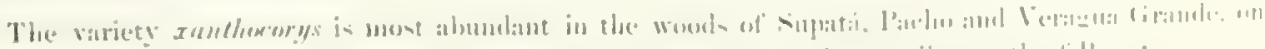

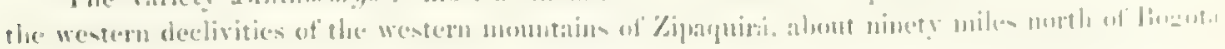





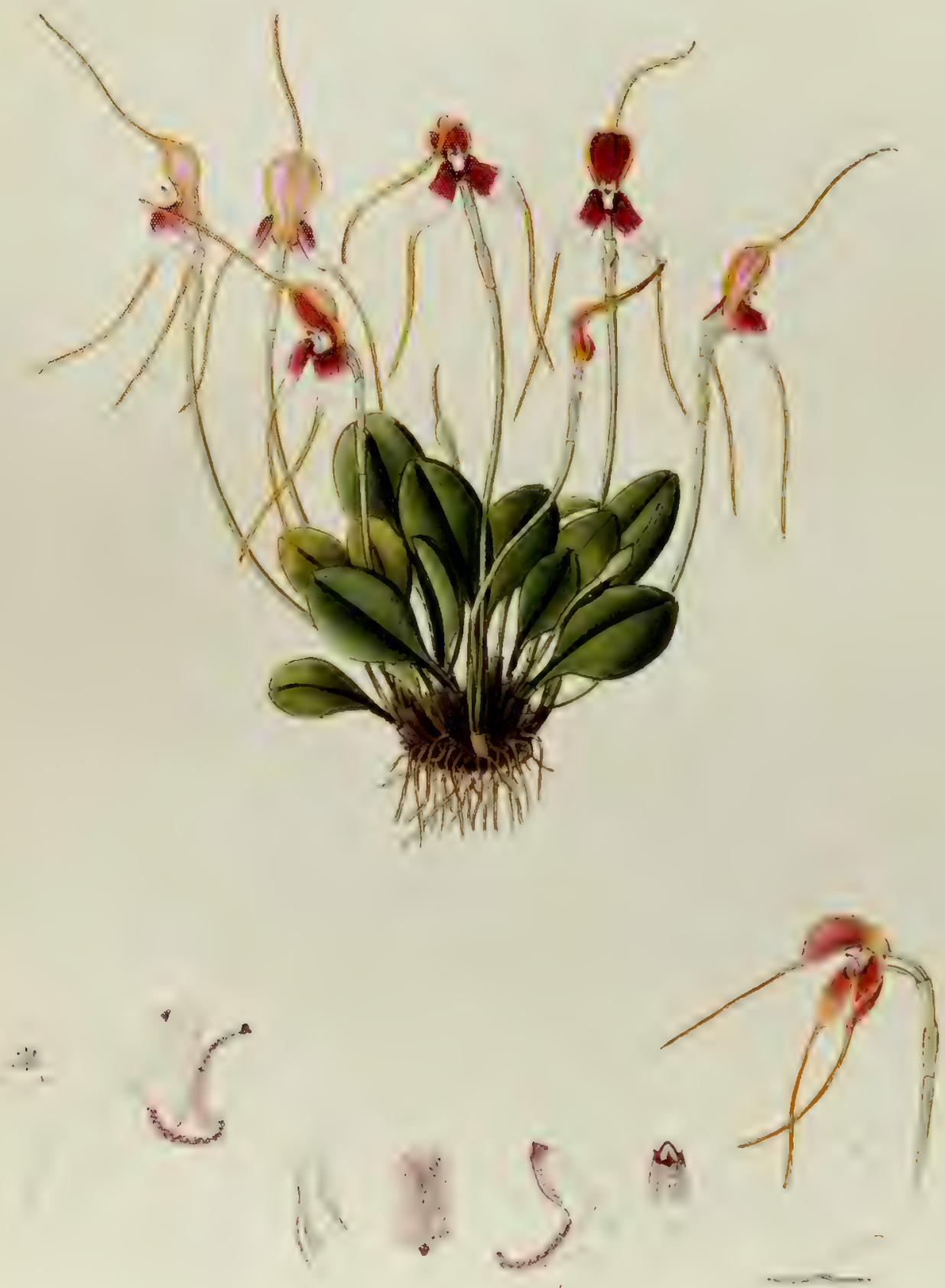


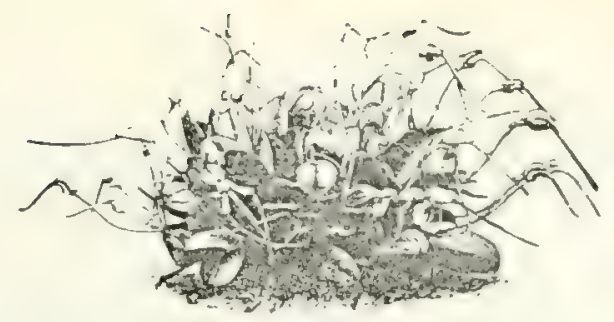

\section{MASDEVALLIA ESTRADAE Rchb. f.}

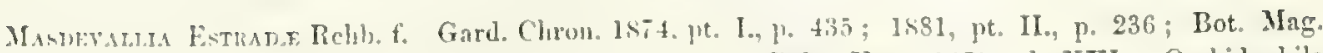
t. 6171 (1875) : Crartenflora (Regel) 1575. p. 37t: Belg. Hort. 1875, pl. XXI.; Orchidopbile

(Godefroy) rol. I. (1SS1), p. 345 with hige; Veiteh Manual Orch. pt. V. (1889), p. 42.

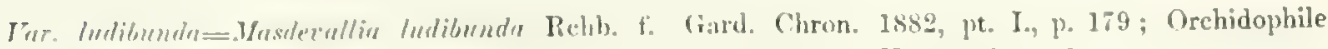
(Crockefrey) vol. I. (18S1-3), p. 27); Veitch M:anual Orch. pt. V. (1889), p. 50.

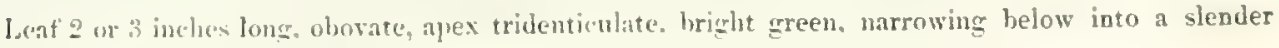
crooted pretiole. shenthed at the base.

I'eduncle, including pelicel, 3 or 4 inches long, terete, slender, with two brownish shenthing bracts, ascending from a joint near the base of the petiole, sonsetimes two or three from the same petiole, pale Ereen: Howering hract nearly inch long, ohlong-ovate, acuminate, sheathing below, with a minute rudimentary but within at the hase. brownish-green.

(Gary alout inch long, with six rounded angles, whitish.

Sepals collering for nearly 1 inch, forming an upen shallow tube, dorsal sepal oborate, cuculhate, 5-nerred. ricl macenta-crimeon, with rellow at the base and mareins; lateral sepals oblong for about sinch. 3-nerved, whiti-l, with rich migenta-crimson at the base; all terminating in slender orange-yellow tails, 1!, inch long.

Petals alout $\frac{1}{4}$ inch long, linenr-ublons, apiculate, with a strong keel on the anterior margin, inner surfice riocil heneath tho kee!, which terminaten in al curred auricle, whitish.

Lip nearly $\frac{1}{4}$ incl lons, whong-omate, flenty and frooved at the base, united to the curved foot of the columm be a vers flexible hinge, pale pink, with numerous small crimson spots, apex a velvety dark crimson bous.

Colum about \& inch long. hroadly winged, white, with magenta font. spex dentate, dark crimson, winge eulged and syotted with erimson.

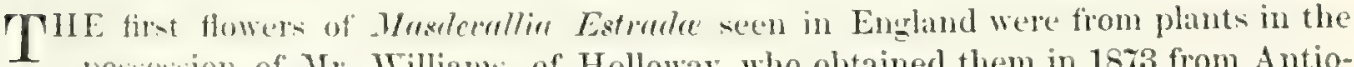
possession of Mr. Willians, of Holloway, who obtained them in 1873 from Antioguia, through a Belgian collector named Patin. Dried specimens had been previously sent to Profenor Reichenbach by Gustar Wallis, from the garden of Señora Estrada, a Spanish lady resdent in Kew Granada. Wallic, howerer, supplied no information as to the luabitat of the plant.

In 1882 a very dosely allied plant was imported by Messrs. Sander, of St. Albans, and named 11. Indibumb by Professor Reichenbach as a distinct species. Careful comparison of hoth plants has, however, convinced me that 1 . Indibunde can only be considered a variety of . W. Eatmole. The flowes of the variety are rather larger and the coloum paler than in those of the type the chief differences being that the dorsal sepal of the varicty is less ercet and more concave, and the wings of the column straighter and natrower:

Explamation of Plate, drawn from a plant at Newbatle dbley:

Fig. 1, petil, lip, and colum, in natural position :- la, section of orary ; - 2, petal, inner side ; 3, lip :-4, column ; - tal, ajox of column; ull enlarged; -5, apex and section of leaf, natural size. 

Consul Lehmann agrees with me in considering M. Ludibunda Rchb. fo to be only a variety of M. Estrado, and supplies, as follows, information concerning their habitat, hitherto unknown:

Masdevallia Estrada grows on trees in thick damp woodo in Antioyuia and Cundinamarca, at an elevation of 2,000 to 2,500 metres $(6,500$ to 8125 feet). It is abundant on the Altu de Alegrias and Cerro Horqueta on the Western Andes of Antiocuua; about Carolina on the Highlands of Santa Rosa ; near La Palma and on the Alto de San Miguel near Medellin; and about the Rohlareito and the Encimada near Sonson and Aguadas. In Antioquia $M$. Estruda grows mixed witb $M$. xanthina, but the two species are easily to be distinguished even when out of flower. The climate of these Jocalities is extremely damp, few days in the year passing without rain, and the average temperature is hetween $14^{\circ}$ and $18^{\circ}$ Centigrade (about $57^{\circ}$ to $64^{\circ}$ Fabrenheit).

The variety ludilunda (M. Ludibunda Rehb. fo) grows in a similar climate in great abundance on the western slopes of the Paramo de Guerrero, the Alto Chaquira and the Phiramo de Pabon in the vicinity of Pacho, Cundinamarca, and also near Zipaquira. 



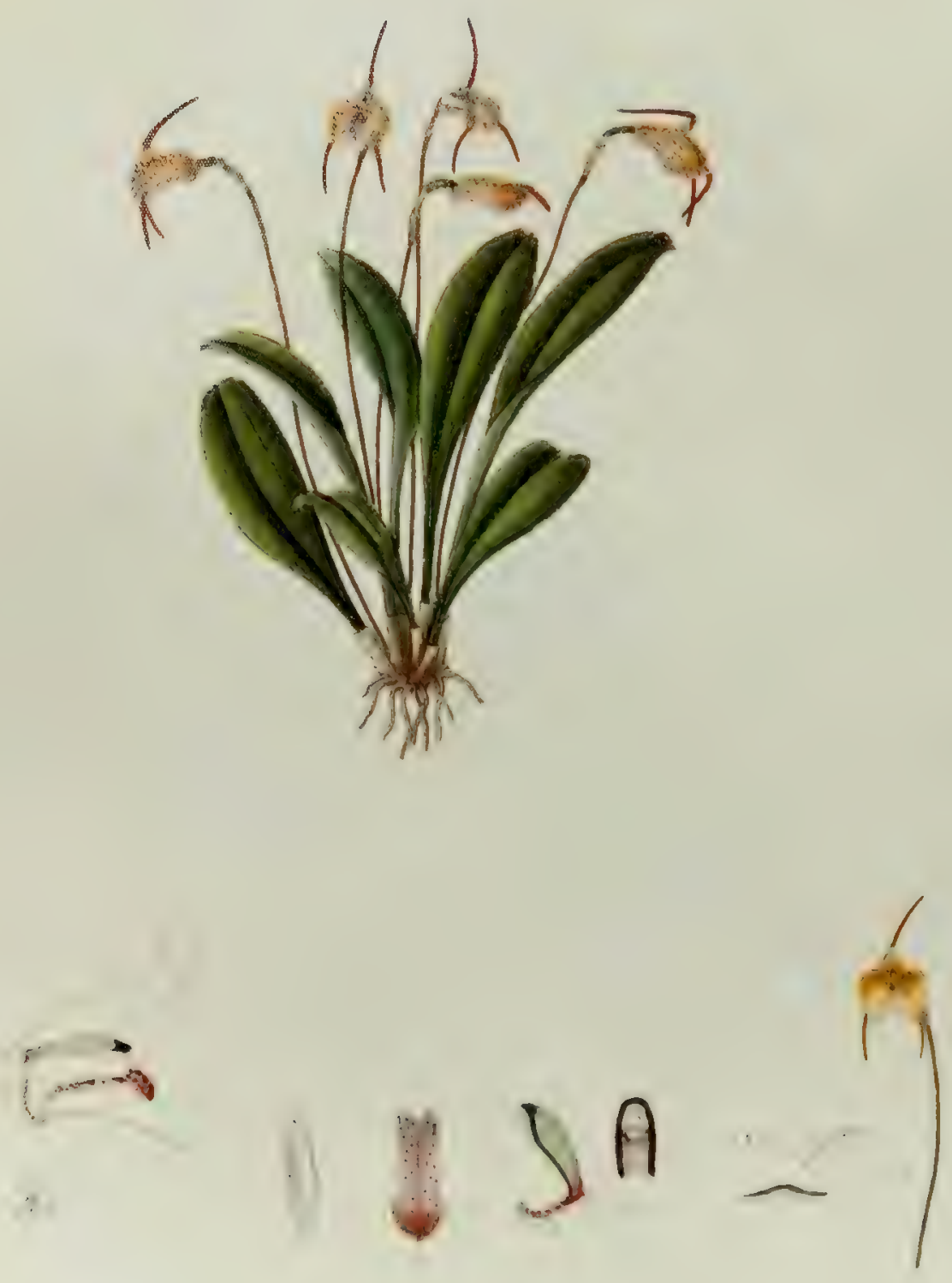


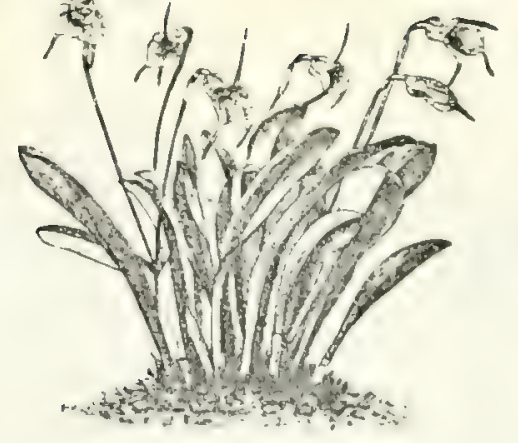

\section{MASDEVALLIA FLORIBUNDA Lindl.}

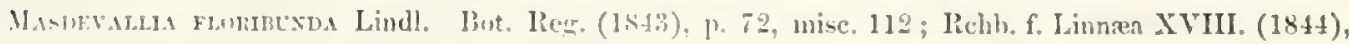

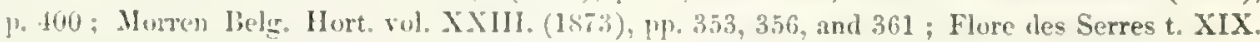
(1873), 1. 132 ; Garl. Chrom. 1877, 11t. II., 1. 610; 1879, pt. I., p. 559 ; 1881, pt. II., p. 305; Godm. et Sals. IBologia Centr. Amer. Bot. Hemsley, vol. III. (1852.1886), p. 207; Veitch Manual (reh. pt. $\mathrm{V} .(1 \mathrm{~s} s 9), \mathrm{r}, 43$.

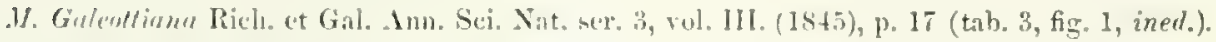

1\%. murinsigme (errme muriosigma) Morren, Beles. Hort. vol. XXIII. (1873), p. 361, pl. XXIII.; Flore

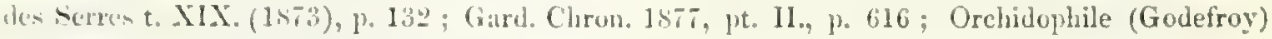

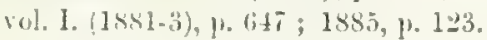

Leat ahout 3 inches long, oblong-lanceolnte, fleshy; ajex tridenticulate, bright shining green, narrowing below into a flexhy groosed petiole, shenthed at the base.

l'etunche abunt 4 inches long, very slender, furete, wiry, with two sheathing bracts, dull green streaked with crimson, ascending from within a shenth at the las of the petiole; flowering loract $\frac{3}{5}$ inch long, memiramens, apiculate, slesthing helow, brownish. with a minute rudimentary bud within at the base.

() wary + inch lomer. hexngonal, curved, with six deep grooves, dull green.

Sepals: dorsal sepal unitud to the lateral scipals for 1 inch, forming a narrow tube, gribbous beneath,

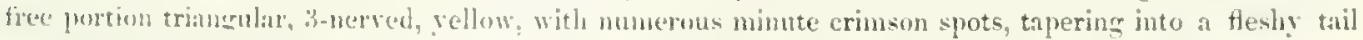

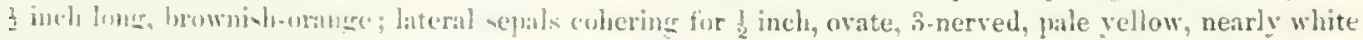

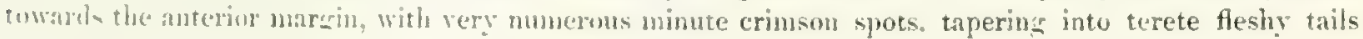

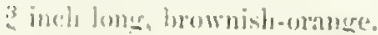

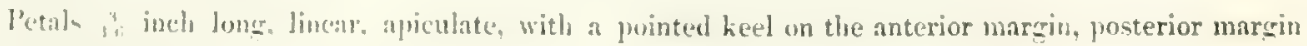
thickencel. white.

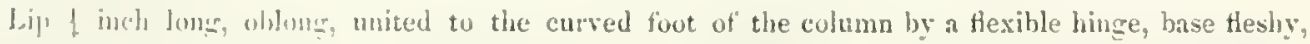
cordate, white, with muneroms minute crimson spots, apex retlexed, dull vellow, with a brown central mark.

Cofum is inch lomer. winged, green, apex and wing blackish-purple, base crimson, foot yellow, apex (n)tires.

THE date of the discovery of $M$. foribuntu is anparently 1840 , when it was found by several botmists in nearly the same locality in the Cordillera of Vera Cruz, South Mexico. Henri Galeotti, a French botmist, who explored and collected in Mexico from 1835 to 140, found it growing on oak trees near Vern Cruz, and Howering in profusion during the greater part of the year. His plants, sent alive to Europe, were probaluly

Exylatation of Plate, draw from a platut at Newhattle Abbey :

Fïr. 1, petal, lip, and column, in natural pusition ;- la, section of orary ;-2, petal, inner side;-

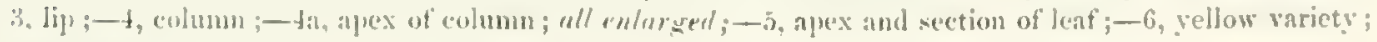
mulur) size. 

those described as $\boldsymbol{M}$. floribunde by Dr. Lindley, who received livine flowers from the garden of Mr. J. Rogers, of Sevenoats. Leibold and Harris also found the plant in 1810, neat Jalapa, at an elevation of 3,000 to 4,000 feet, and from Leibold's specinens Protessor Reichenbach wrote his description in "Linnat," 1sH. Specimens were described in 1815 under the name of $M$. Geflettenn by Achille Richard and (ialeotti, and a drawing of the plant was made by the latter, but was, unfortunately, never published. The second synonym, myriostigme, was given to the plant in 18 sa ly Mons. Morren, editor of the Belgique Horticole, under the impression that it was specificalts distinet from 12. floribumle. The plants thus named were hought hy Mons. Oner de Malzaine from Cordova, about fifty miles w.s.w. of Vera Cruz, and were cultivated in the gardens of Messrs. Jacoly and Makoy, at Liege.

At the present time the name $M$. myriostigma is applied by foreign horticulturisth to varieties of $M$. floribude more or less differing from the type. The unspotted getlon variety represented at fig. 6 of the accompanying Plate was sent to me by Mensto. Secerer and Tropp, of Dulwich, who purchased it in Belgium as M. myriosfigmer. So far as $1 \mathrm{~mm}$ aware, the closely spotted form most common in this country, and the palc yellow. almost spotless variety, represent the wo extremes of varion, between which numerous gradations are to be met with, the internal structure and colouring being in all cance identical. Professor Reichenbach states that the little brown dots scattered over the sepals ranish as the flower fades, when it appears simply gellowish. I have never found this to be the case. In spotted flowers the spots are visible, thomgh periaps not quite so dark, after the flower has faded; and in freshly-gathered Howers of the yellow varicty the only spots present are few in number and very minute. 




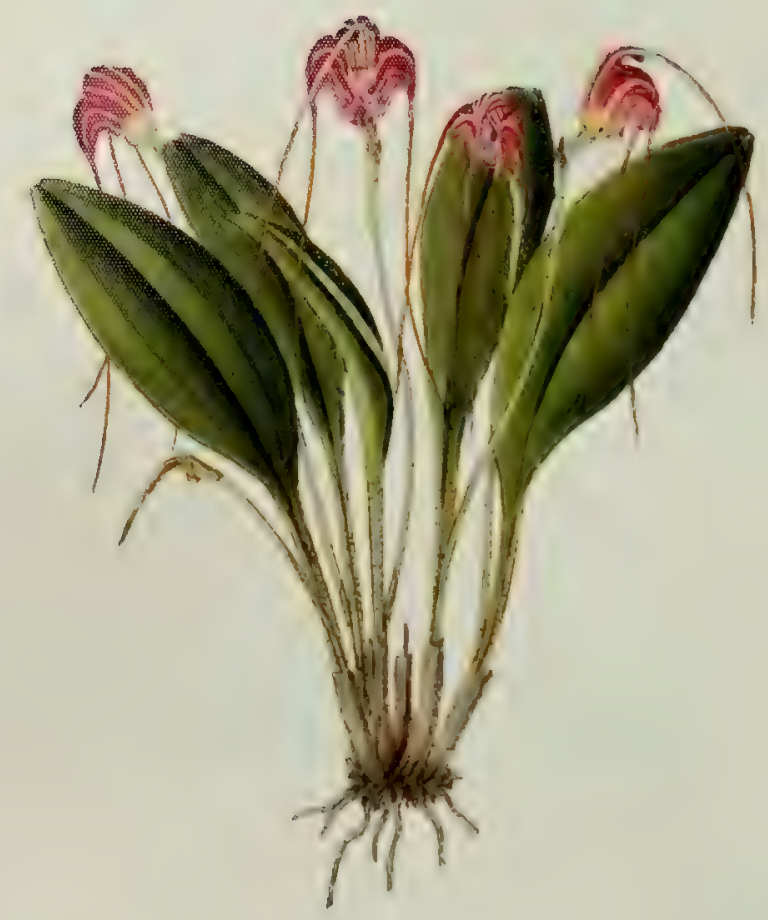

9

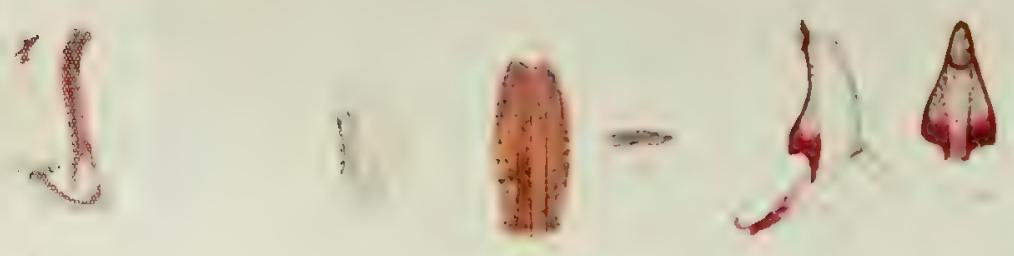

$\therefore$ 





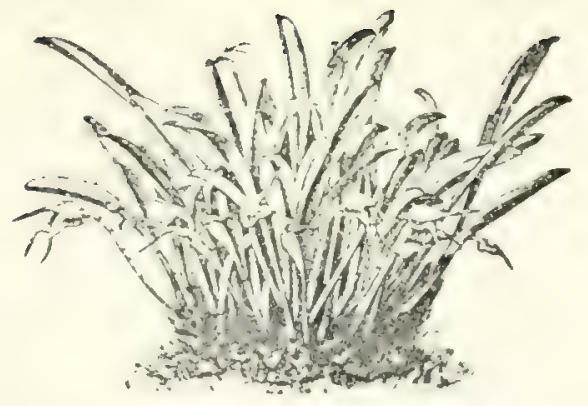

\section{MASDEVALLIA IONOCHARIS Rehb. f.}

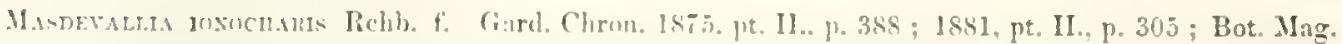

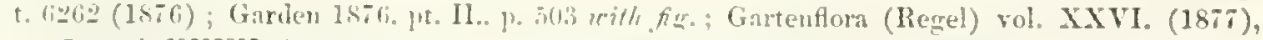

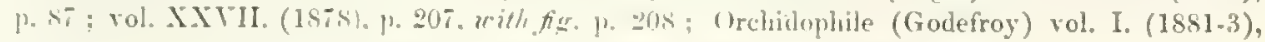
1. 666. with.fig. as in Gartenfora; Veitch Itanual (Breh. pt. V. (1859), p. 48.

Thr. "ppurotints hort.

Leaf 4 or 5 inches Jone and about inch wide. ovate-lanceolate, cariuate, apex acutely tridenticulate, bricht green. narrowing helow into a slender sronved petiole. sheathed at the base.

Peduncles or 4 inches long, witl two shenthing bracts, terete, slender, ascending from within a sheath at the base of the petiole, pale sreen: Hewering bract $\frac{b}{a}$ inch boner, carinate, apiculate, 3-nerred, with a rudiusntary bud withu at the base, brownish-erreen.

(Wary $\frac{1}{y}$ incli long, with six grooves, pale grecn.

Soplals cuhering for ahout $\frac{1}{2}$ inch, forming a widc wiblous tube, greenish-white, spotted with rosepurple: free portion trimerular-orate fol alsout inch. "Benerved, the neries strongly carinate on the outer white, white, covered on the inner suface with minute relvety lairs, and terminating in slender greenishrellow tails 3 inch loner.

l'ctals about ${ }_{4}$ inch bug, oblong. apiculatc, curved. broadly heeled and angled on the anterior margin. the inner sturface viacid beneatla the angle of the kerl. jalle transprarent irory-yellow.

Lip abont 3 inch bong. finly and deeply groved at the base, unitrd to the curved foot of the column hy is very thexible linge. pandurate, white, with rose-purple spots near the hase, and two lontritudinal

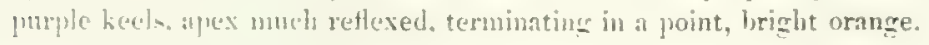

Colunm about + inch lone, brondly winged, whitish-green, spotted on the foot with rose-purple, apex minutelv denticulate.

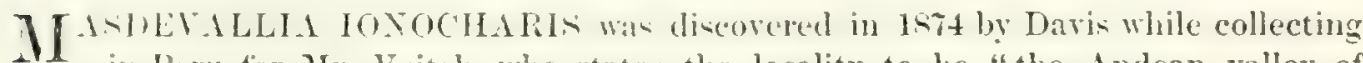
in Pert for $\mathrm{Ir}$. Veiteh, who states the locality to be "the Andean valley of Sandia, in the province of Caravaya." at an elevation of 9,000 to 10,000 feet.

A variety of this species exists in more than one collection under the name of Merstemllin "ipmmrintu, the flowers of which itre whiter, more slender, and less spotted; the column also is entirely white and the lip more briglatly mathed with rose-purple. The leaf is darker sreen, and the denticulation of the apex is sharper than in the type. I ean olstan no information as to the history of this variety, except that it was sold at Steresn' Rooms ly Vexsm. Protheroe and Morris in February 1857 under the above nane, which does not appear to have ever been published or attached to any distinet species. The plant is probably merely a local variety of $M$. ionochrois.

Explanation of Plate, drawn froun a plant at Newhattle Dhbey :

Fig. 1, petal, lip, and column, in natural position;-la, section of oray ; -2, petal, inner side; -

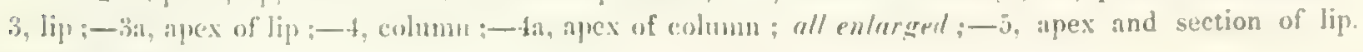
natural size. 




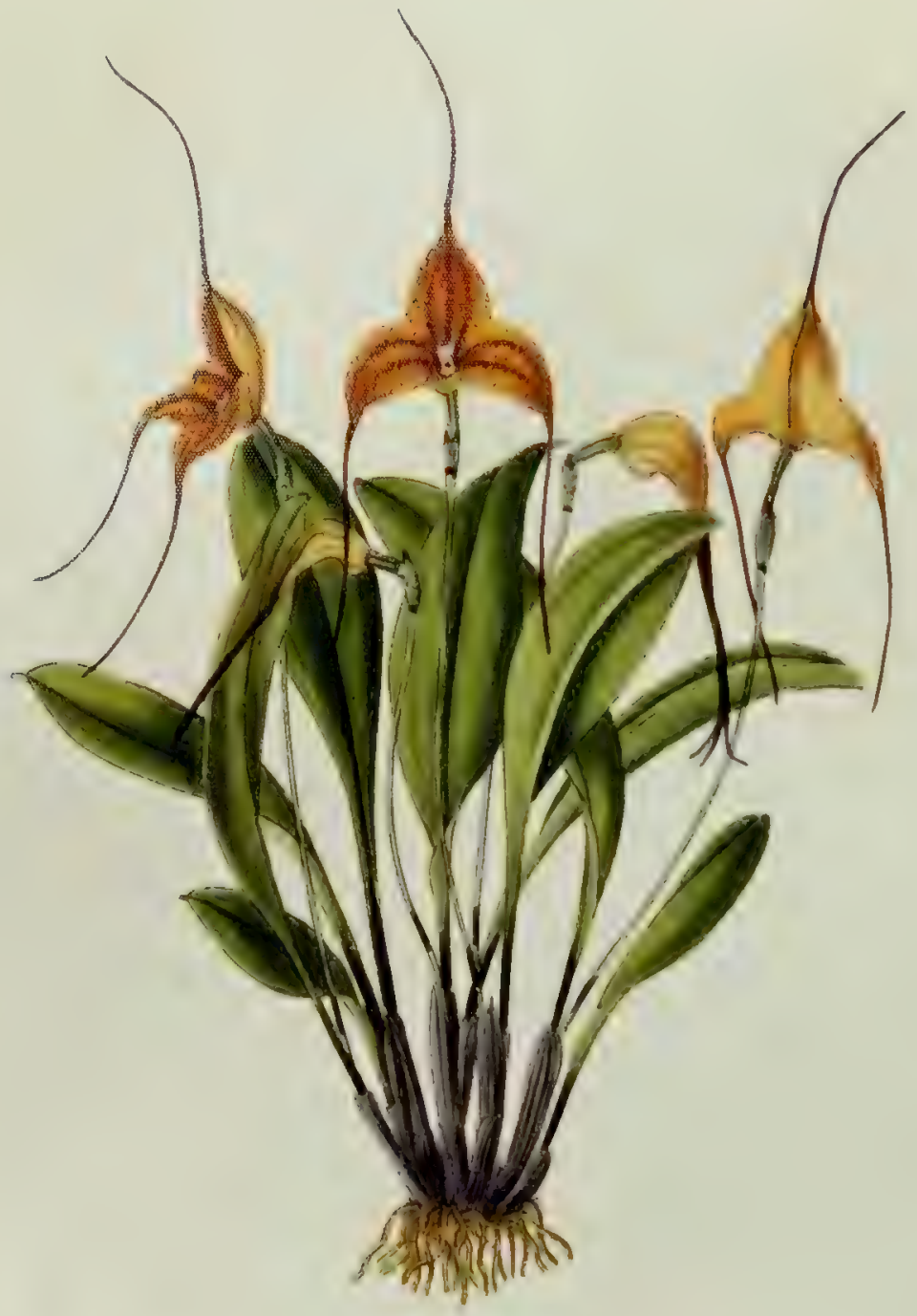

2

(.

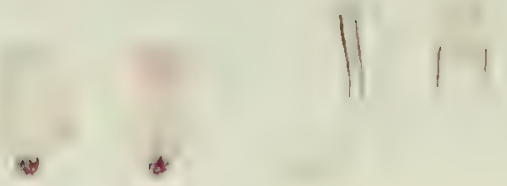




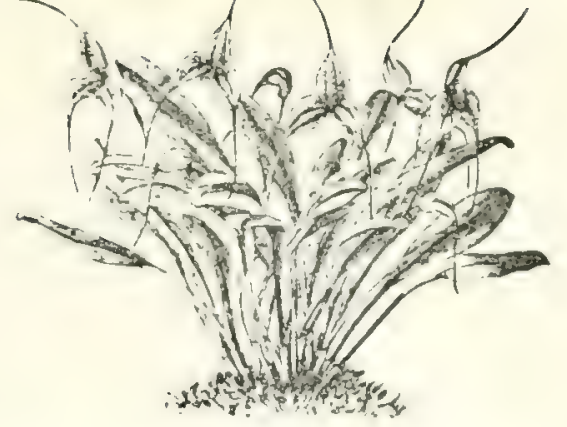

\section{MASDEVALLIA TRIANGULARIS Lindl.}

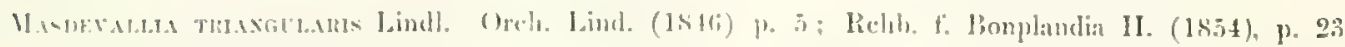

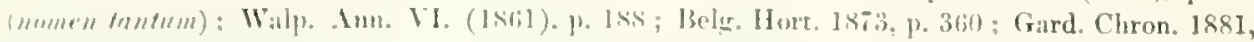

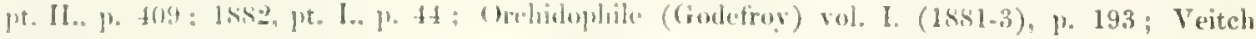

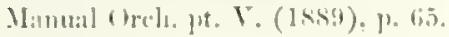

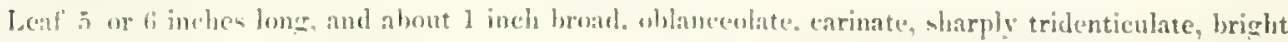

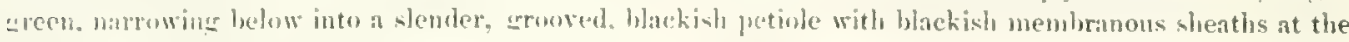
lisse.

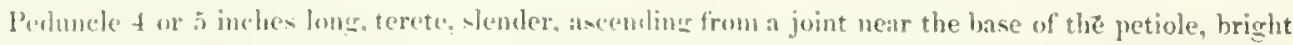
errech, with a few minute black dots and ane or two hlachish bracts; fowering bract $\frac{3}{8}$ inch long, oblong.

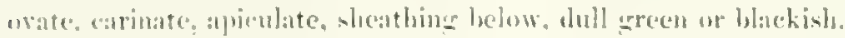

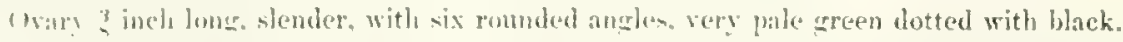

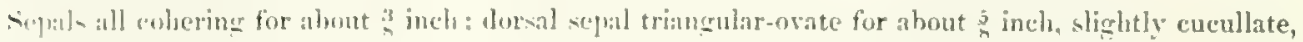

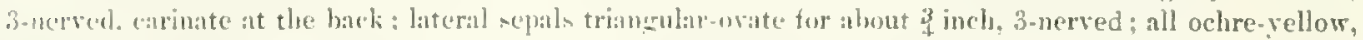

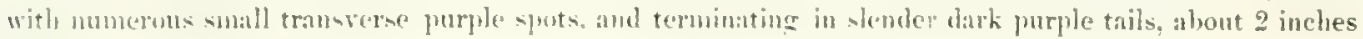
$\operatorname{long}$.

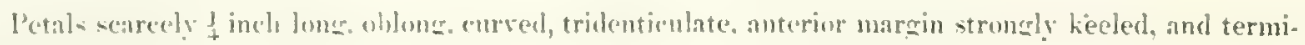
mating in a lone curving ancle, white.

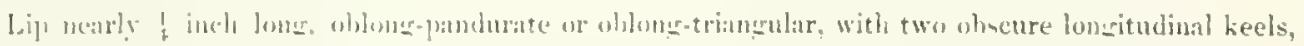

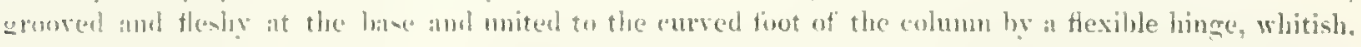

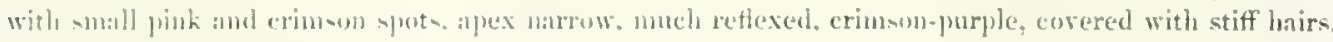

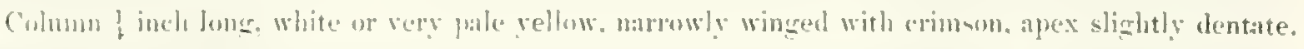

$\lambda I^{1+1}$

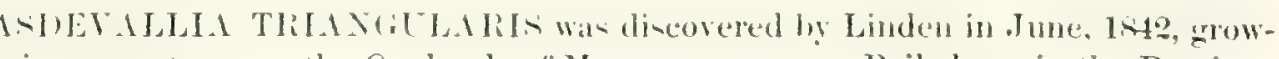
ing upon trees on the Quebradat of Mumuquem, near Bailadores in the Province of Mcridi, Venezuch, at an altitude of 4.800 feet in a temperature of $6 S^{\circ}$ Fahrenheit. It was atoo found near Caracas by Watener and in Tovar hy Moritz. The first living plants were imported in $1881 \mathrm{by}$ Mr. F. Sander, of St. Albans, and the richly-coloured form represcuted in the aceompanying Plate is probably a plant from his original importation, my first drawimg of the species having been made in 1883 , at Newbattle - Hoser This variety appears to be mare, for the flowers of most plants now in cultivation are more sreen than yellow, only slightly spotted, and with greenish-purple tails.

Consul Lehmimn sende the following note:

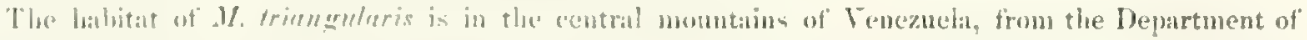

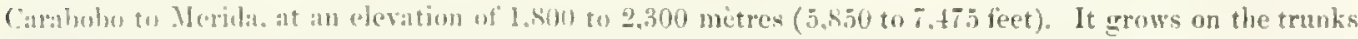

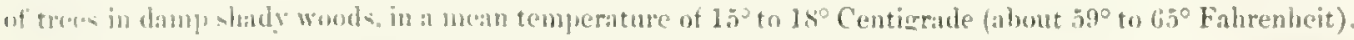

Exylanation of llate, draw from at plant at Newbattle dhey :

Fig. 1. petal, lip. and colnmm, in natural position;-1a, section of ovary ;-2, petal, inner side ; -

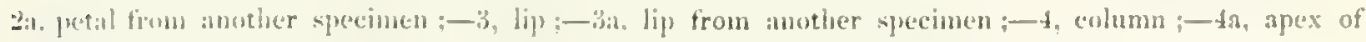

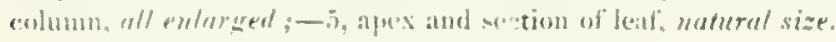






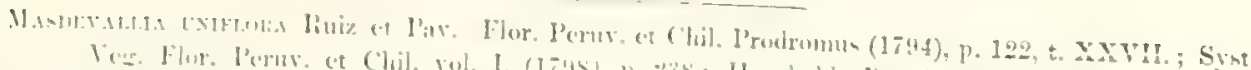

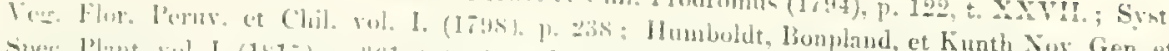

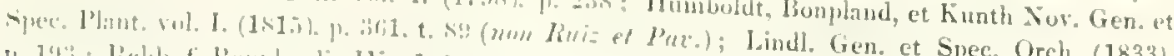

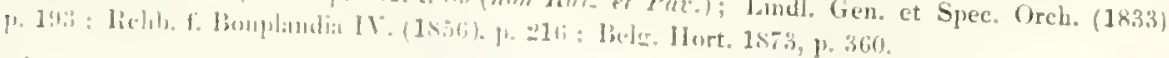

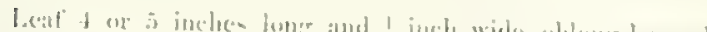

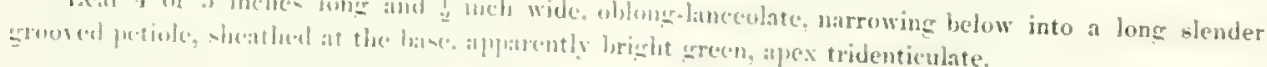

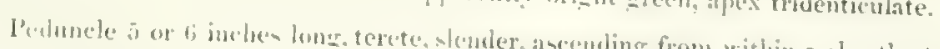

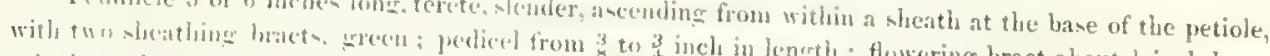

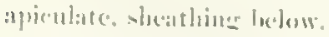

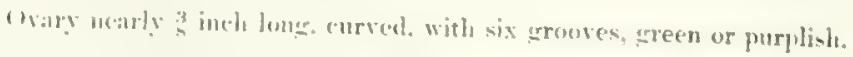

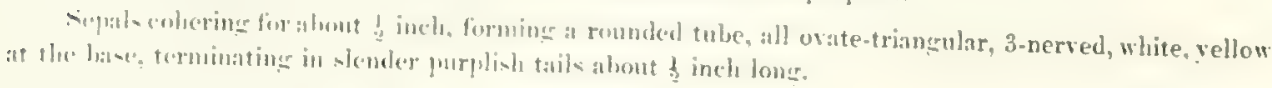

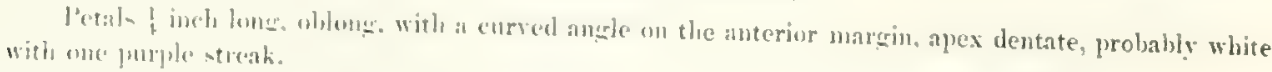

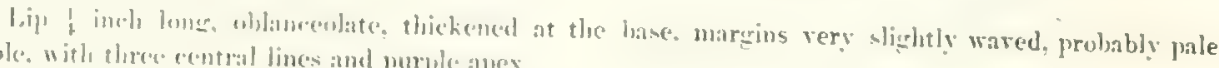

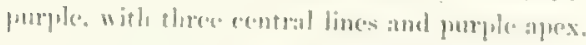

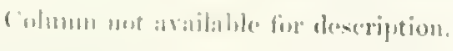

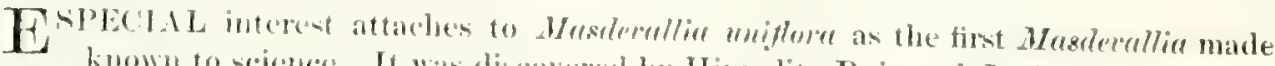
known to science. It was diecovered by Hippolito Ruiz and José Pavon, Spanish botanisto who tratedled in Pert and Chili hetween the gears 1777 and 1793 , to explore

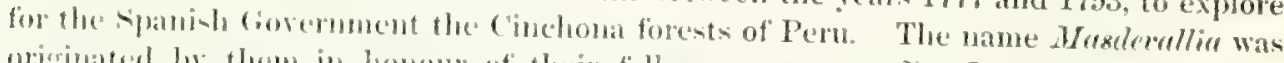
originated he them in honom of their fellow-comutryan Dr. Josepho Masdevall, a celdurted botanis and physichn of the cightecuth century. The only locality known

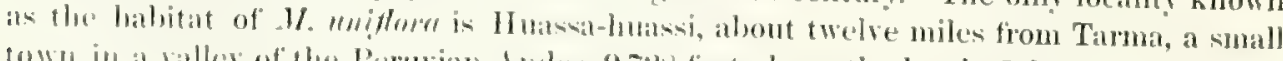

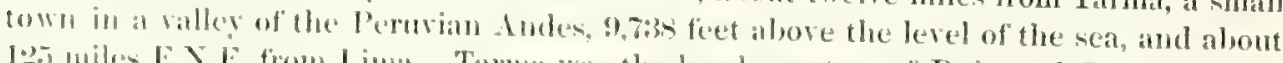

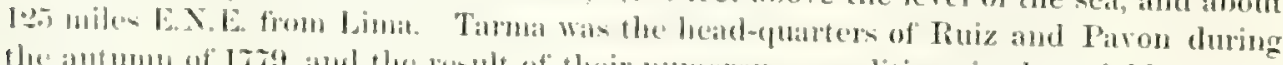
the antums of 1829 and the renult of their numerous expeditions in the neighbourhood of this town was the diecosery of mang new and rave plants. At the date of their visit to Huane-bum-if. it Was a small village of about forty inhabitants, and is described by

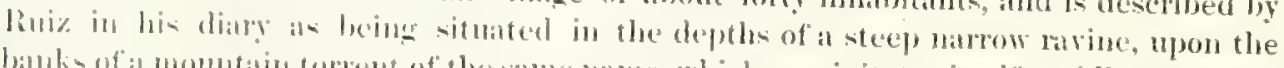

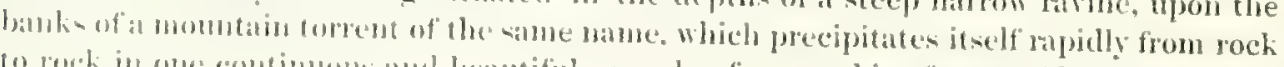

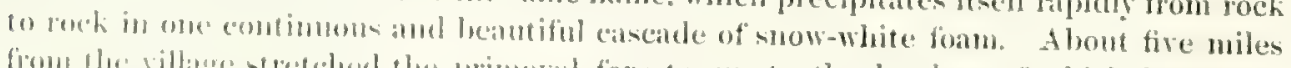

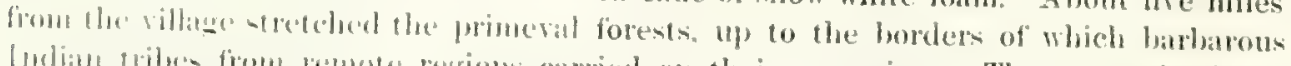

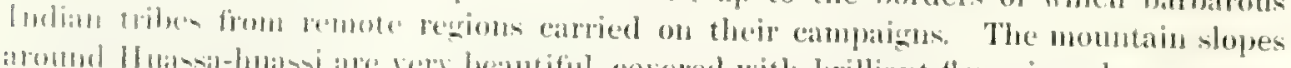

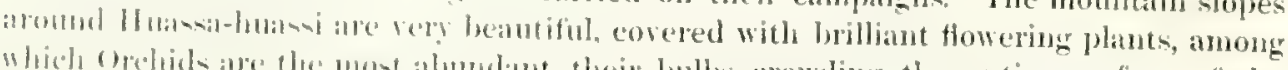

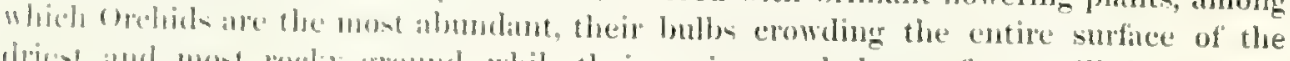
dricel and mont rocky eround, while their curious and cleagnt flowers fill the air with frateriallece.

In Ihe Quichua hanghage-the hanguge of the Ineas of Pern-the name Huassa-

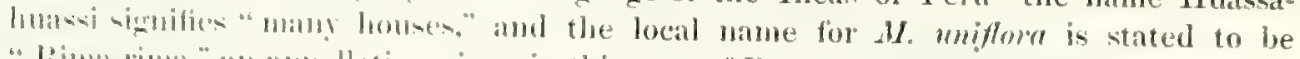

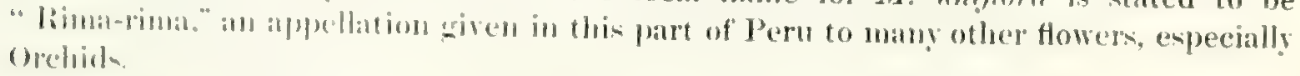

Sillec it dineovery, more than one humbed gears ago, M. miflom has never agrain heent met with. and there is mes record that its habitat has since been visited by any

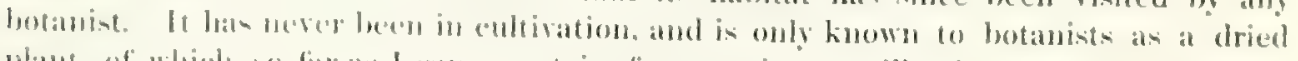

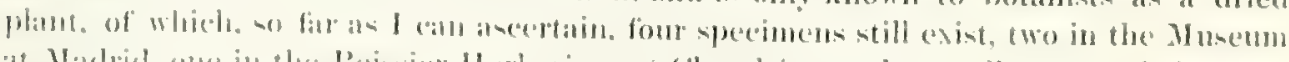

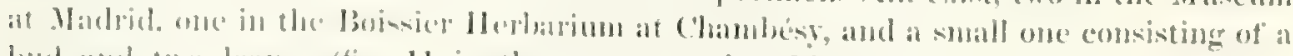

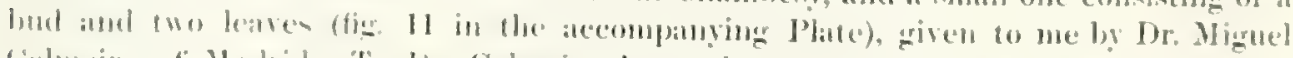

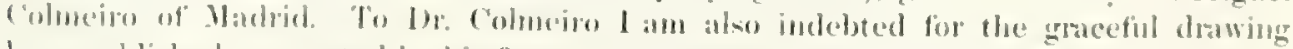

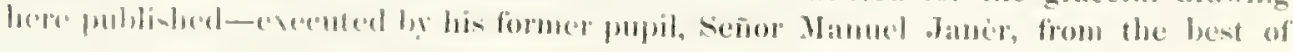

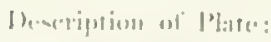

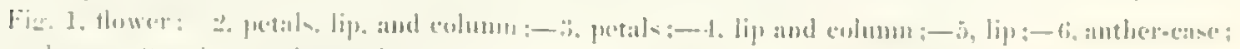

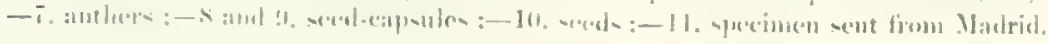



Ruiz and Paronis speerimens-ans well as for an exact dencription of the colouring of the flowers, taken from umpublished notes by the two botanists. This dalualbe material has

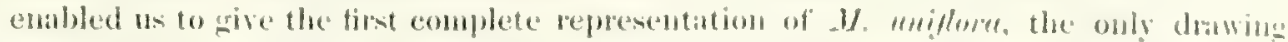
made by Ruis and Pavon being a wood-cut of at single detached flower, with hotantical detaik, publistred in the Prodromus of their magniticent book upon the Flonat of Peru and Chili. It was evidenty their intention to prepare a more complete drawing of the plant, for, in their "Sistema Vegetabilium" a sevesth volume of their great worh is referred to; only four volumes, however, were published. Fo fresh flowern of HL. Uniftore heing avalable for dissection, it has been thought advisable to cops the botanical details from the wood-cut given by Ruiz and Pavon, as shomn in the aceompanying Plate at tigso (i to 10.

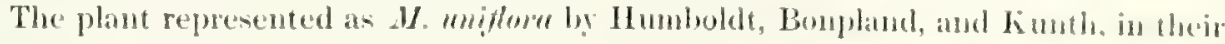
"Nova Genera et species Plantarum," is undoubtedly not the original yeecies so batmed

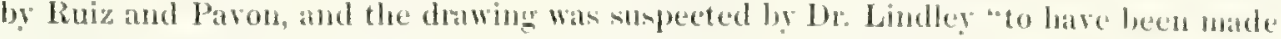

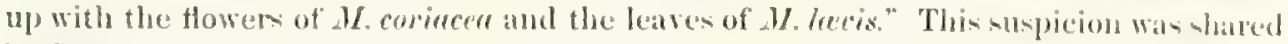

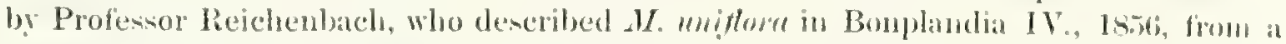
specimen which lat formed part of a rery vahable collection of dried planto betongibe to Paron, and after his death discovered by Mons. Renter lidelen away in an wat in Matrid. Mons. Reuter purchased the collection for the Boissier Herbarium, of which he was then Curator, and the Orehids were submitted to Profesor Reichoubach for exannation and deseription. The present C'untor of the Boivier Herbarims. Hons. Eurene Lutru, hats most hindly allowed me to examine this specinen, which combists of four leaves and two flowers, with one petal and lip detached. the apparent colouring of the sepals agreenge exactly with the colour-elescription quoted helow from Ruizin manuscript at Madrid. A drawing of this specimen, together with the smatl drifed piece and the drawing sent to me from Madrid by Dr. Colmeiro, mal le secn in the Natural History Huseum at South Kensington, to which I have prenented them in order to preserve a record of every known example of this interesting and minterioun plant.

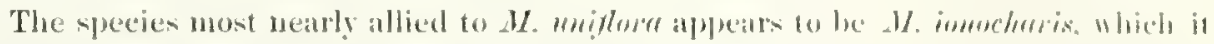

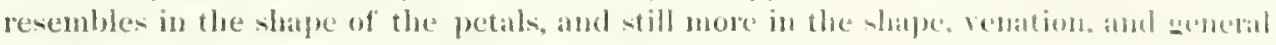
appearance of the sepals, ats well ats in the onthe of the leasen. with their bome sender petioles.

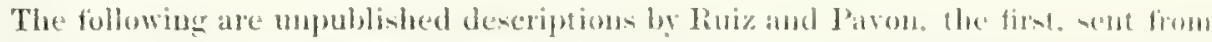

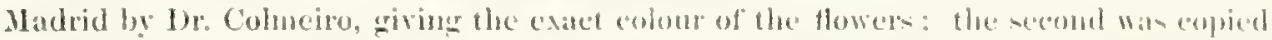

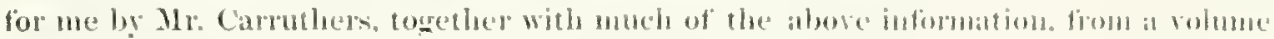
of manuseript notes by Ruiz is the Botanical Libmary of the Sotumal Histury Mancum, from which atso Consul Lehmann kindly trandated for me kuxs atecomut in spanials of the neighbourhood of Huassit-luassi :

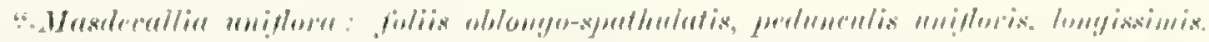

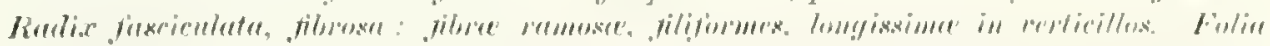

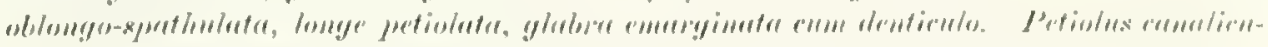

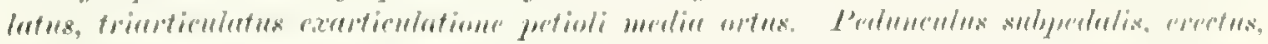

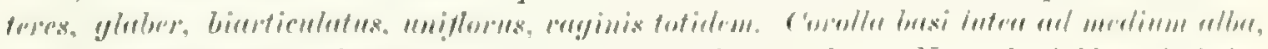

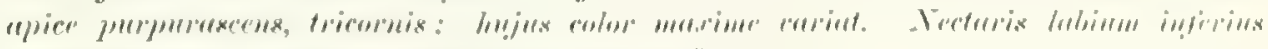

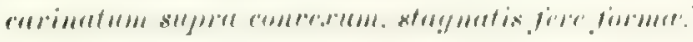

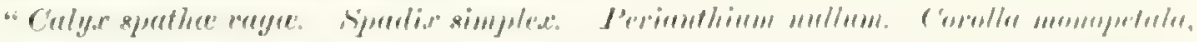

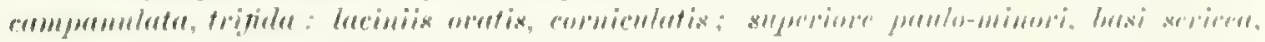

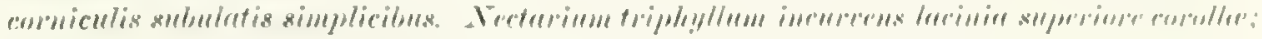

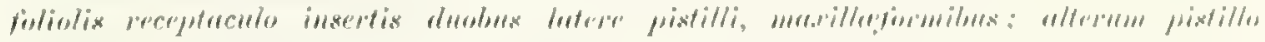

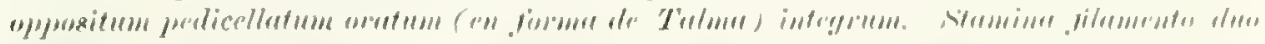

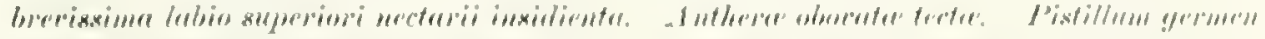

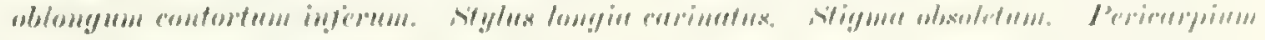

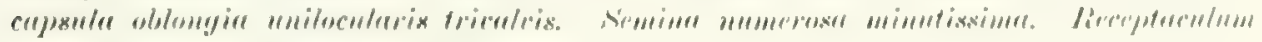

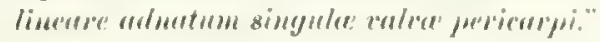




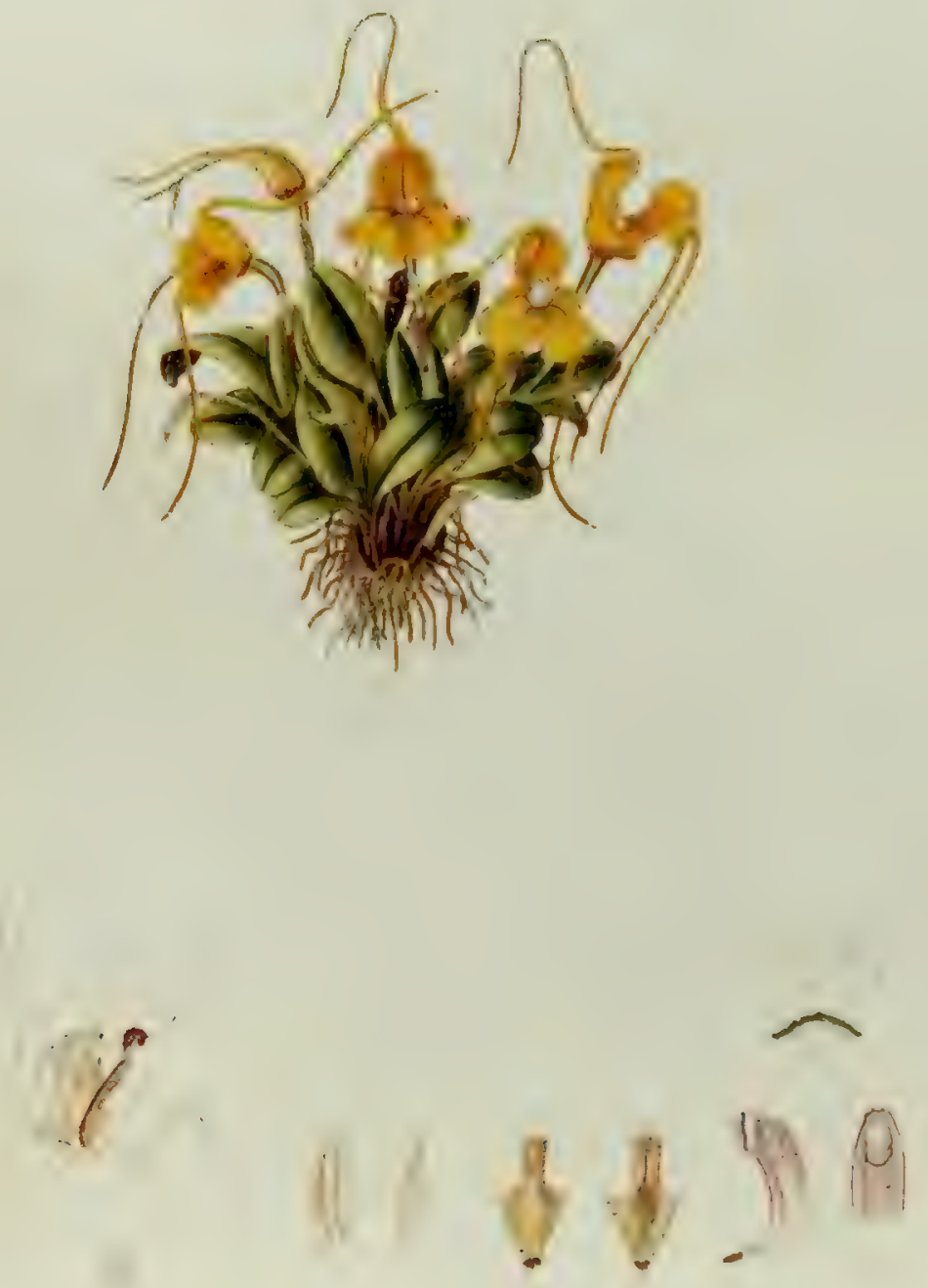


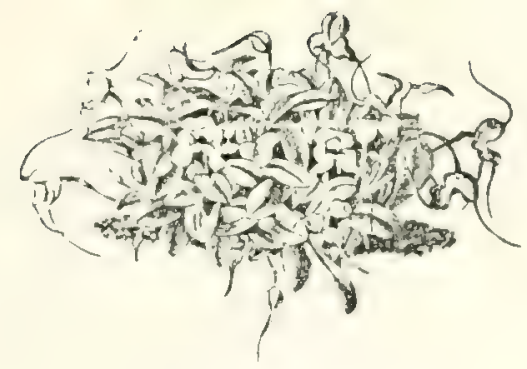

\section{MASDEVALIIA WAGENERIANA LINdl.}

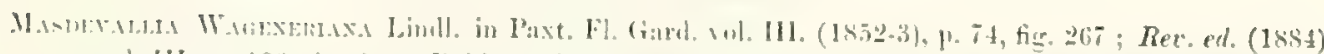

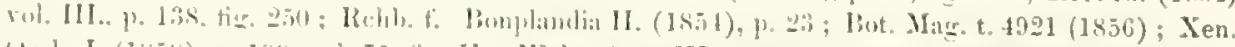

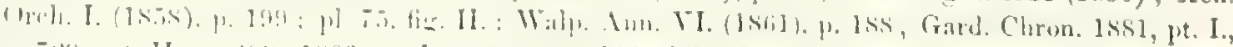

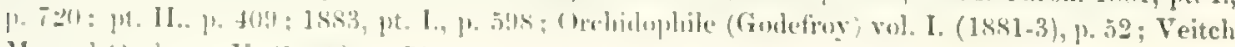

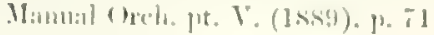

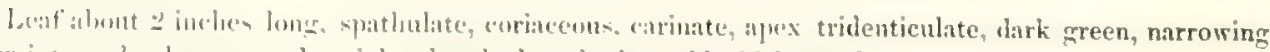

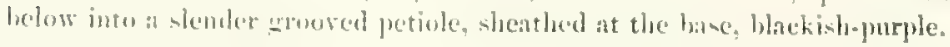

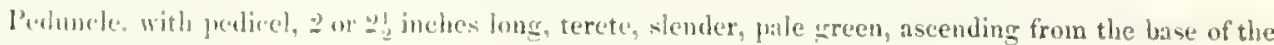
petiole, with two pale green or bhoki-h sheathing hracts; Howering bract about o inch long, carinate, apiculate. slesthine, with a minte rudimentary but within at the base.

Wary ! inch long. witls six rounded angles. areen. with minnte biack dots.

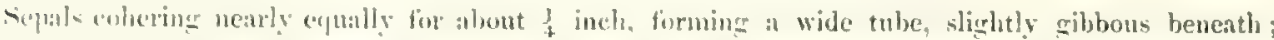
dorsil s"pal ovite for about ! inch, s-nerved. cneullate: lateral sephals cordate, 3-nerved, margins reflexed ; all bright "lear vellow, with umocrus uninte cromson spots and crimson nerves, and terminating in

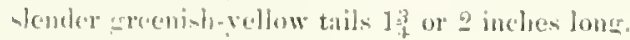

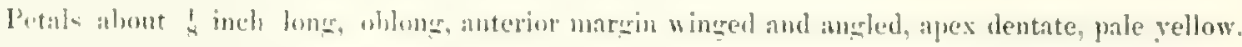

Lipnearly : iach long, mited to the fout of the colum by an extremely flexible hinge, margins of

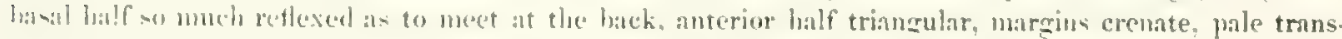

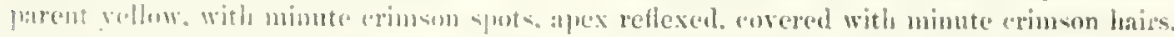

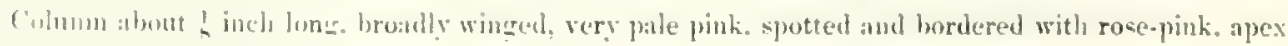
ilentite:

Thl: only localities recorded as the habitat of $M$. Wagencrimu are in Venezuela, Where it wat discovered by Horit\% in February, 1849, growing on trees in the Cicmun Colony of Towar. In fuly of the following year it was found by Wagener at an clevation of 6,000 feet near Cambobo, a village about nine miles south-west of Valencia, in Venczuch. Wagener's imported plants flowered at Brussels in 1851 under the care of Yons. Linden, for the first time in cultivation. From these specimens a drawing was published ly. Profexor Reichenbach in $155 \mathrm{sin}$ "Xenia Orchidacea." The woodeut in Pintonis "Flower Garden" represents a flower with the sepals tightly closed together, and is evidently drawn from a faded specimen.

Explanation of l'late, dran wron a plant at Sewbattle Abley:

Fir. 1. petal. lip, and colum, in matural perition;-1a, section of oviry ;-2, petal, inner side :-2a,

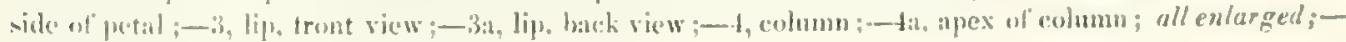

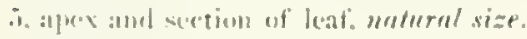




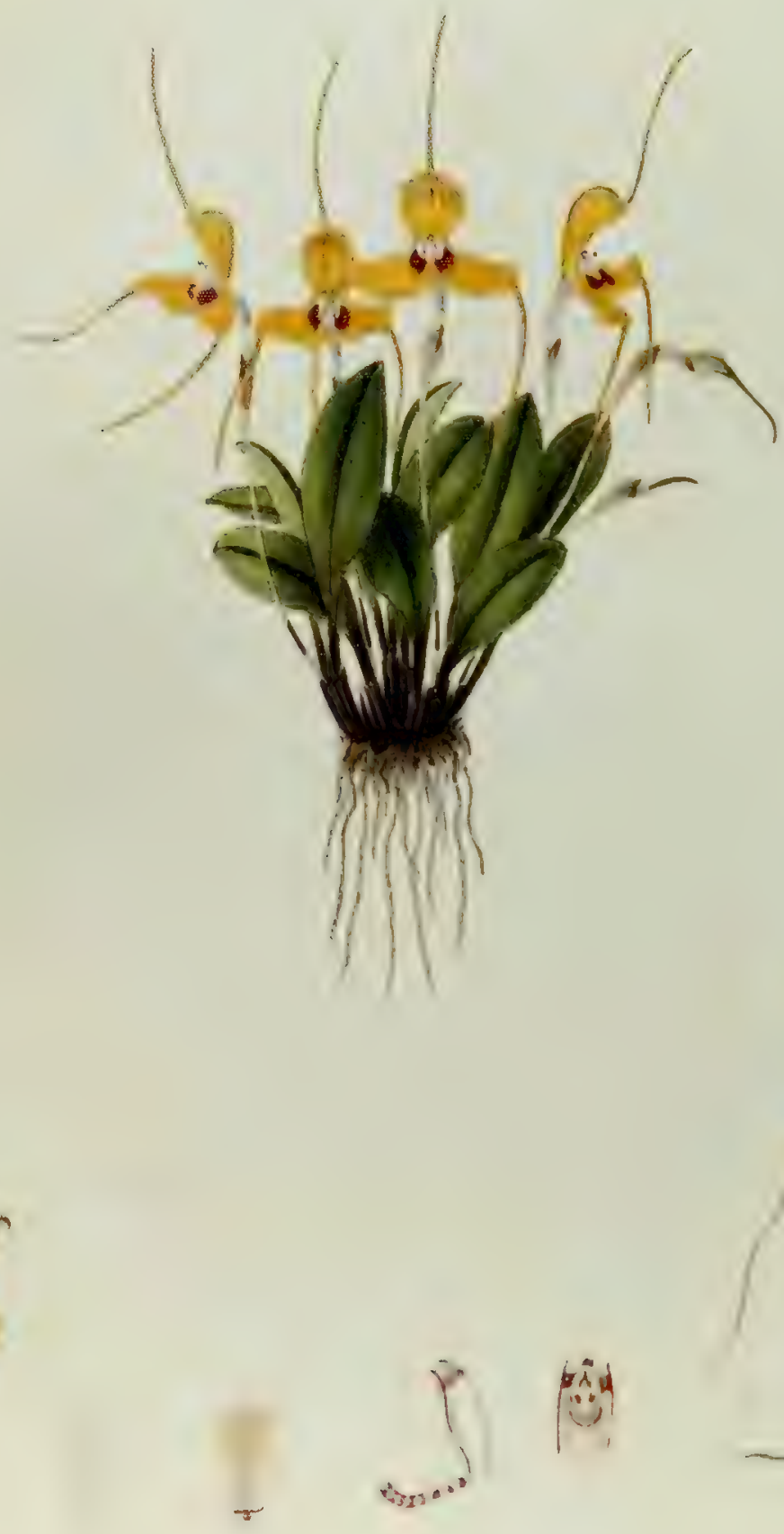


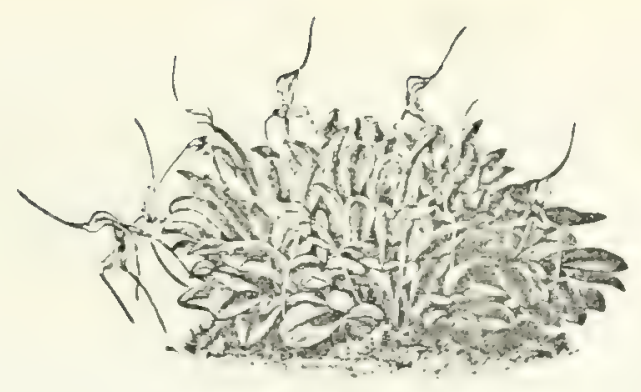

\section{MASDEVALLIA XANTHINA Rchb. f.}

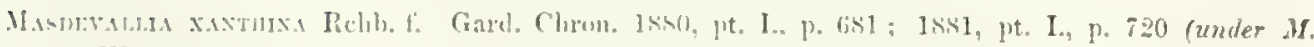

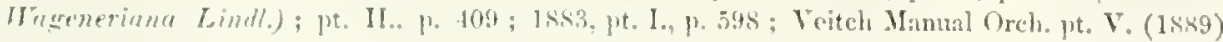
1). 4 (as. H. Estrade zar. ramblima).

Iar. pullide, rar. nov.

L.ent 2 or 3 inches long. and alsout 3 inch wide, ohlong-ovate, enrinate, apex sharply tridenticulate, dull ercen, narrowing below into a slender wrooved petiole, sheathed at the base and stained with black.

I'uhuele ucarly 3 inches lone, slender, erect, terete, with one or two shenthing bracts, very pale gecell : thwering bract 3 incl lone, 3-nerved, sheathing below, apheulate, brown or blackish-green, with a minute rudimentary loud within at the base.

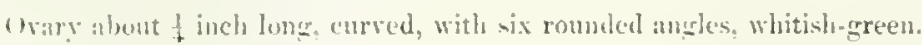

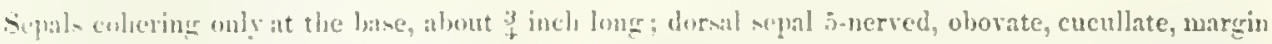
recurved at the bane, brilliant yellow, the werves artenish at the back, tapering into a slender tail $1 \frac{1}{4}$ or 1! inch long, crange at the apes, sreenish at the hase; lateral segals ol, Jong, 3-nerved, brilliant yellow, with a darli crimson blotels at the base of each, terminating in slender tails 1 inch or $1 \frac{1}{4}$ inch long, orange at the apex, greenish at the base.

Petals abut ! inch lone, vblone, with an incurved lieel on the anterior marrin, apex tridentate, ivery-white. acmi-trams marent.

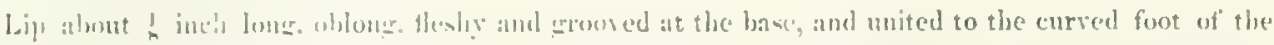

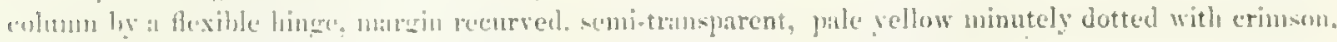

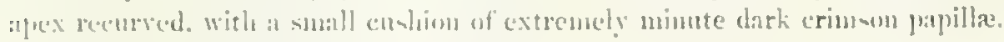

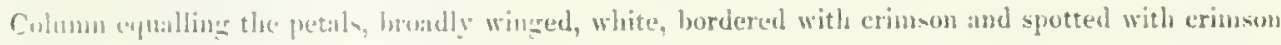
an the wings aljex and furt, spex asentely trilentate.

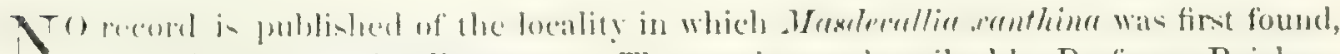

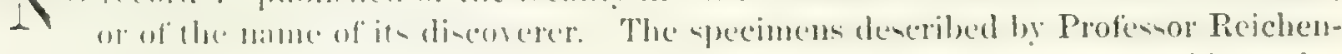

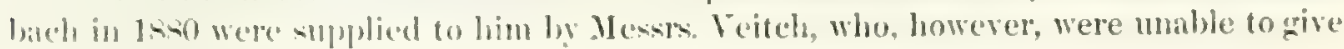
any information ats to its origrin.

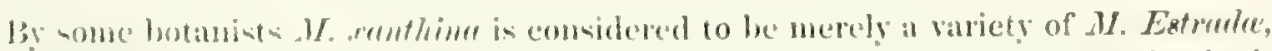

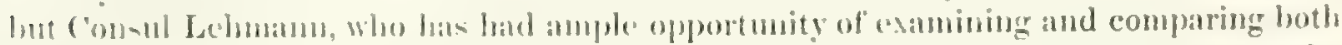
phanc in their native habitat, is strongly opposed to this theory, and dechres them to be specifically distinct, M. ormthime lecing in itself a very variable species, ranging over a

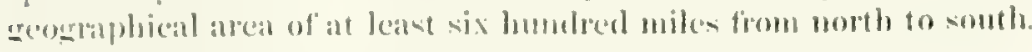

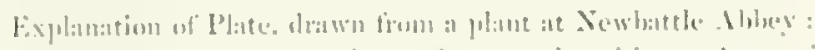

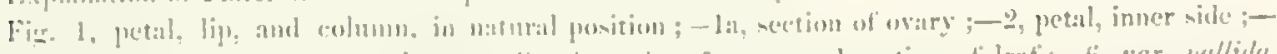

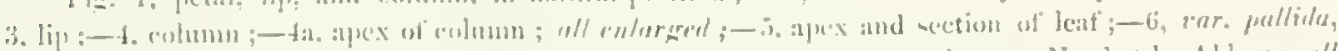

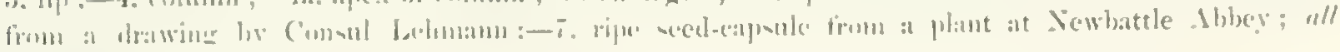
Iulurul sizer. 

The numerous names of localities mentioned belon by Consul Lelmam, most of them not being marked in any map yet published, will probably convey lut litte information to any person unacquainted with the district. It in hoped, howerer, that with his assistance all these names will be indicated in the map interbed for publication with the final chapters of the present work.

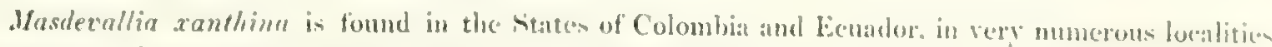
It grows near the ground upon the trunks of ontis and other trees, in deme and rery damp woods. at an

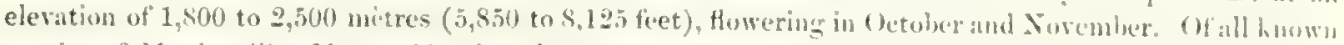

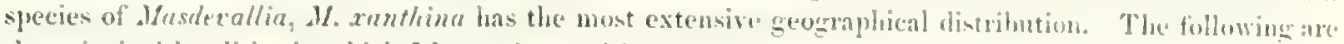
the principal localities in which I have observed it:

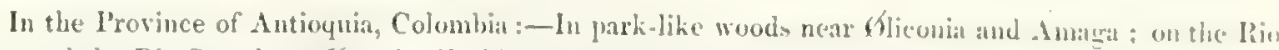

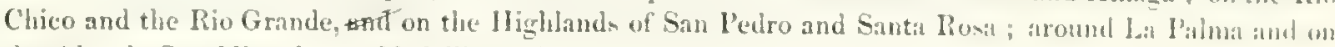
the Alo de San Miguel near Medellin, and on oak trees in great abundance about the hohbarcito nean Sonson.

In the Provinee of Canca, Colombin :-About La Ceja near Inzi, and in the vicinity of the Rin

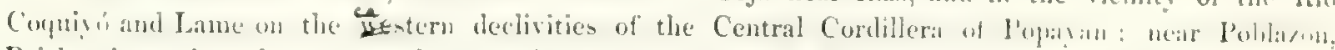
Paishamba, and on the western slopes of the rolenno of Sutari ; in the vicinity of l'anitian and Almagner,

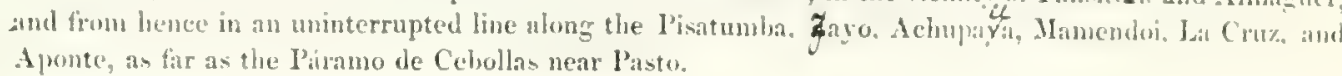

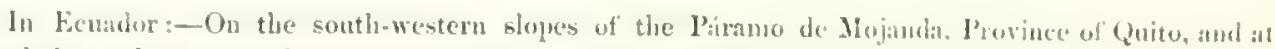
Chiguinda on the castern slopes of the bastern elmeks of Cuenca.

Still further sonth, on the eastem Andes of lajin, I oberved a few vents ang some plinto which probably belonged to this species, but as I found we flowers, it must remain an opent ynestion whether M. xanthina extends as far south.

It is generally a very abundant species. and expecially so in the dintriet between I'olatyin and l'asto, but the plants rarely attain large proportions. Shade and constant daujuren are essential to the growth of $M$. xanthina, and the entire area of its distribution is rematrable for these chanacterivice. The num. ber of days without rainfall is very small throughout the year. The anmal average remperature of the region ranges between $14^{\circ}$ and $18^{\circ}$ ('entigrade (ahbut $57^{\circ}$ to $64^{\circ}$ lalurenleit).

The extensive geographical distribution of $1 /$, ranthine cansen considerable variation in the size and colour of the flowers, but this variation is not sufticient to justify the opinion that W. Estrade in only a variety of this species, although in some places in Antioquin the two plants ane to be fond frowing together. The only form of 11 . xanthina known in cultisation comes from - Intivequa, where the thowers are smallest, and generally of a bright apricot yellow colour. Further nouth, in the province of Canca, they become larger, and paler in colows. In plants growing on the roleano of Sotari and at Paislanbla near Popayin, the flowers are nearly pure white, and lave not the pmrple yot at the base of the lateral sepals, which is a constant feature in the flower from all other localities. The Guito variote in the mont

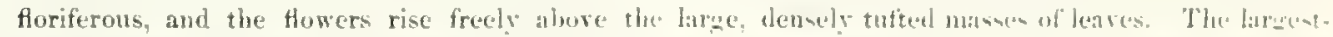

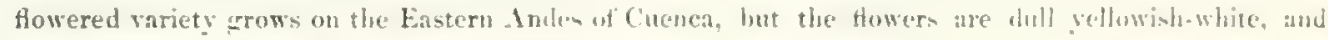
sometimes speckled with very. ninute browni-ht donts. 



\section{'TRIARIS'TELLAE Rehb. f.}

Tllt plant of this section are distingushed by their small linear leaves, wire-like Hower-stems, and boat-shaped lateral sepals, cohering for almost their entire legenth, the dorsal sepal being united to them for only a short distance near the base. sevent yecies are known only in Horharia, and have never been named or described.

\section{3 species tigured:}

Masdevallia gemmata Rchb. fo $(=M$. trichete Rchb. f.) triaristella Rehb. f: ( $=M$. (ridactylitex Reht. t:) triglochin Rehls. 




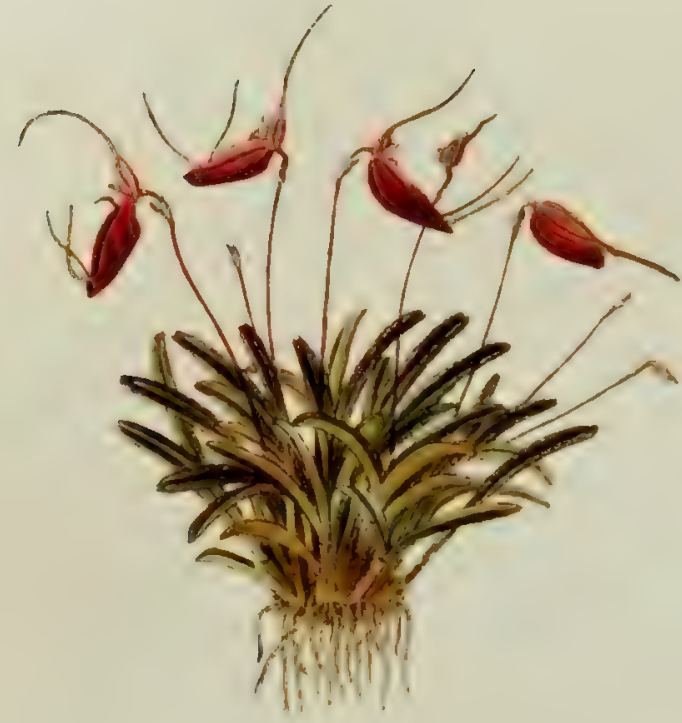

if

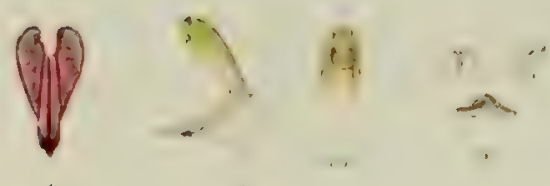




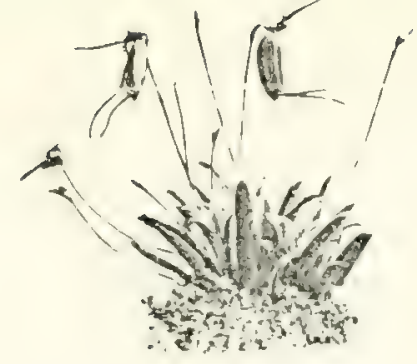

\section{MASIDEVALIA GEMIATA Rehb. f.}

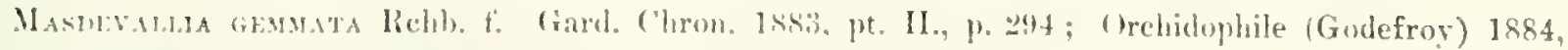

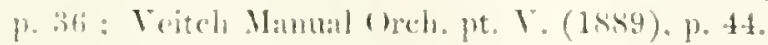

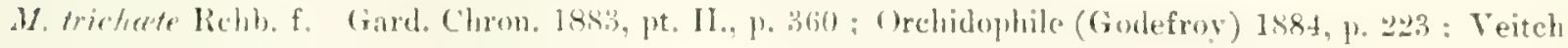

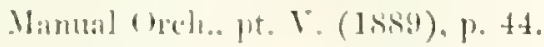

letaf 1! or 2 inches lome. lincar, Heshr, gromed on the upper side, apex tridenticulate, narrowing holow into a sender torete pretiole. sheathed at the hase, dull green, often deeply tinged with reddishfimplese

P'ofuncle nearly in inchen long terete, thread-like or wiry, ascending or lateral from the base of the pretiole. producing two or three flowers in succession, with one or two closely-sheathing bracts, dut!

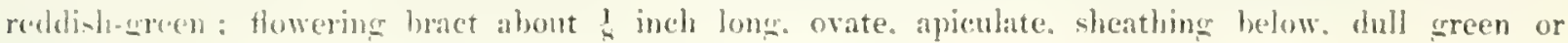
brownisls.

Wruy abmit inch lome. with six rounded angles, sometines crenate, dull ereen.

Sopalin: dorsal sepal united to the laternl sepals only near the base, tree portion triangular-ovate for about ineh, inerved. cucullate, reddish-yellow, reined with crimson, and terminating in a slender vellow

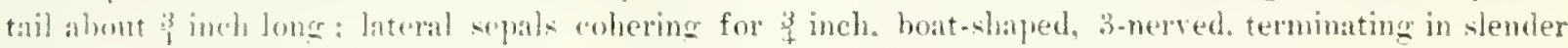
vellow rabls about inch long. dull redelish, shaded and reined with crimson.

l'ual, 1 inch lomer. oval, apex tridentate, pale yellow, with a crimson ceutral streak.

lop hemere than the petals. nuited to the foot of the colum by a flexible hinere, cordate, with three

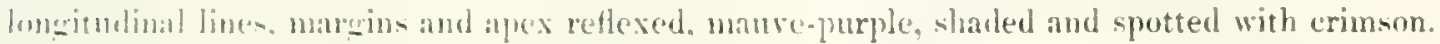

('ohmun a lithe fonger than the petals. nurowly whed, apex denticulate, yellow tipped with green, the fout pink.

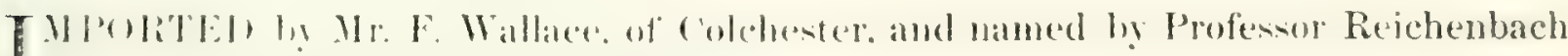
in Ist:" with no record of its habitat.

Explanation of l'aite. drawn from a plant at Newbattle Abhey :

Fin. 1. peral. lip, and rolum, in natural position ;- la, section of ovary ; - 2, petal, inner side ;-

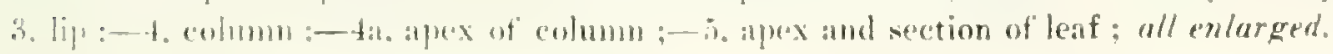





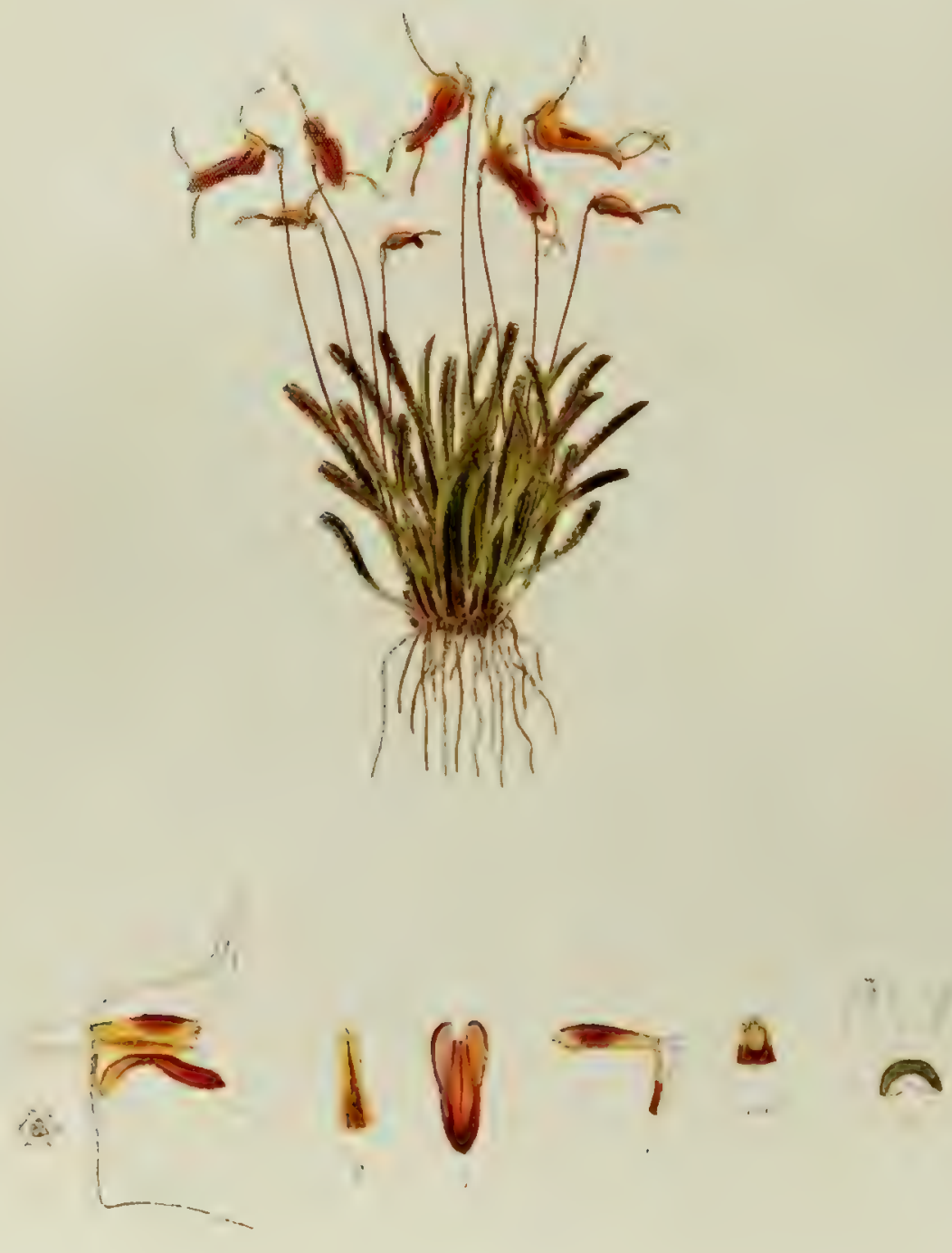



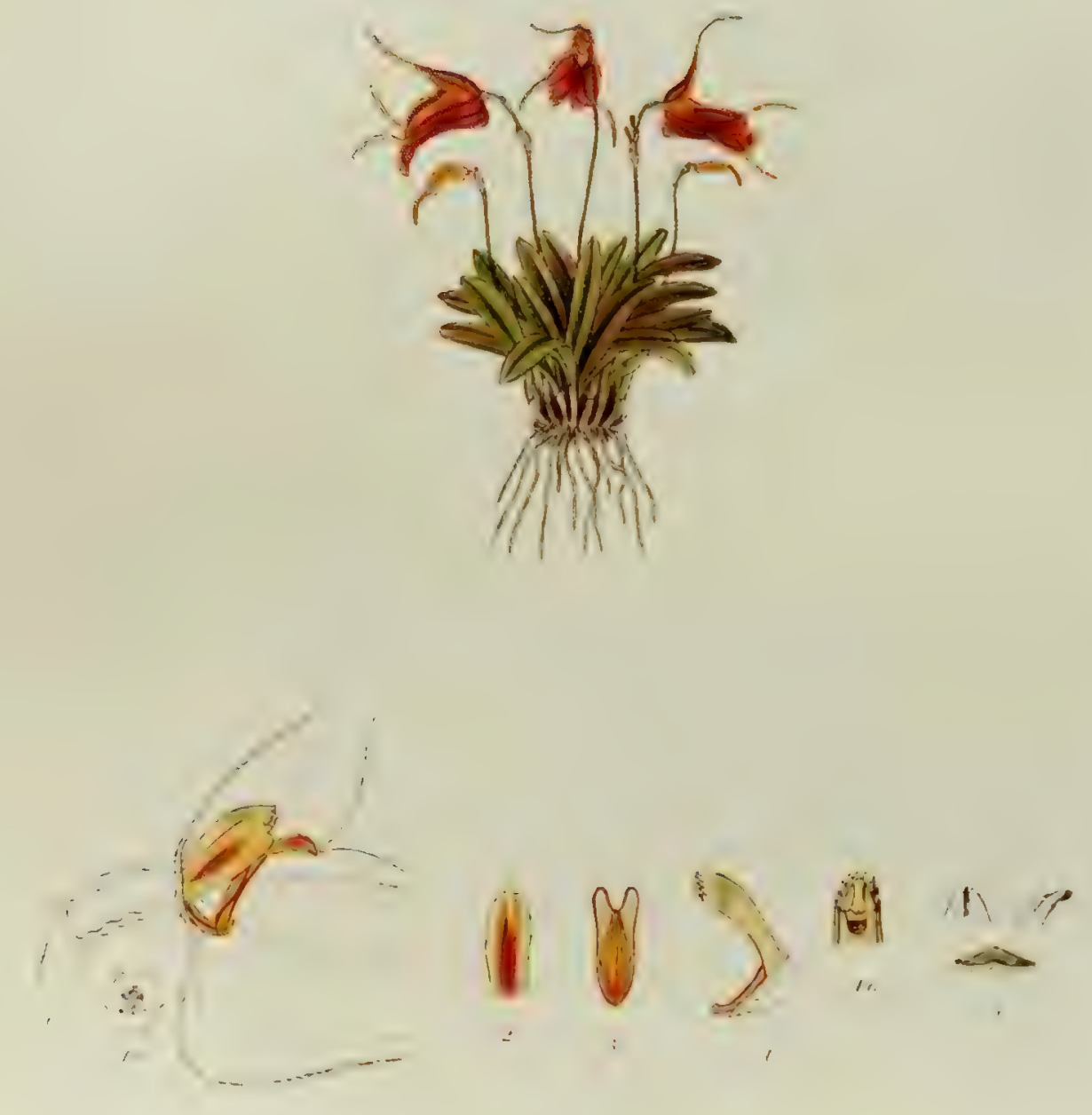


\section{MASUEVALLIA TRIGLOCHIN Rchb.f.}

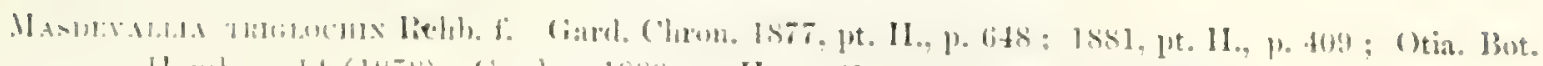

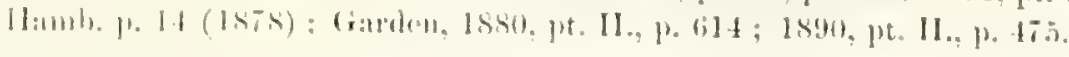

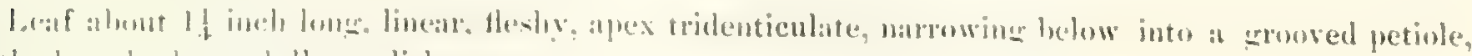

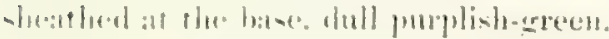

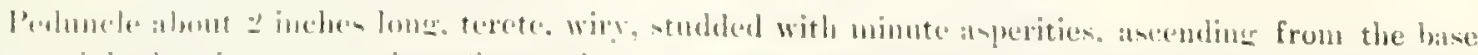

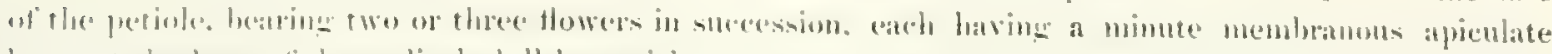

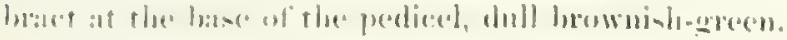

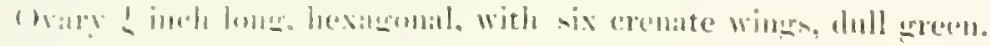

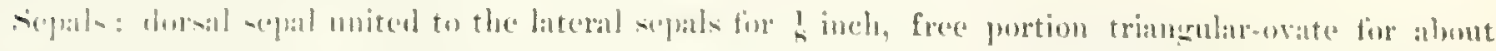

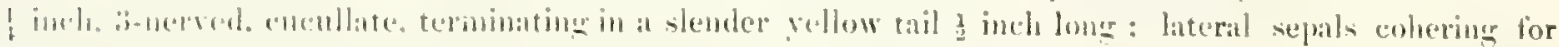

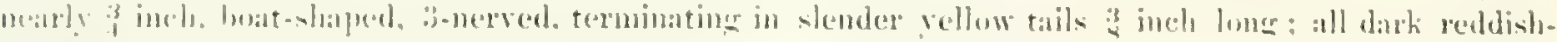
relluw shated and reined with dark red.

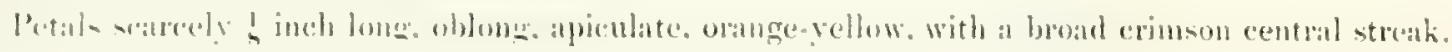

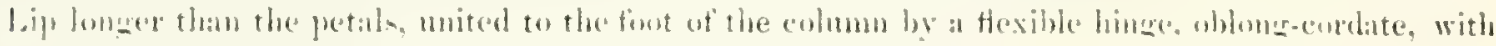

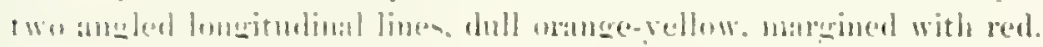

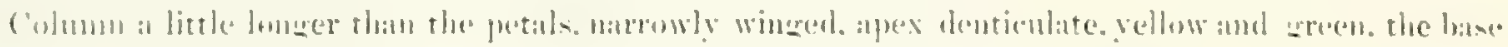
and linit entered with real.

II

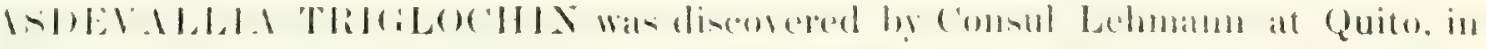

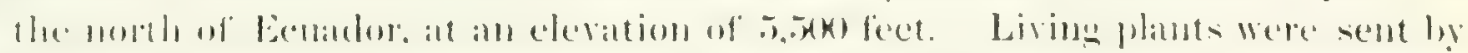

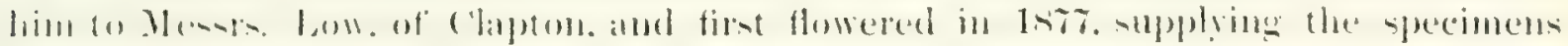

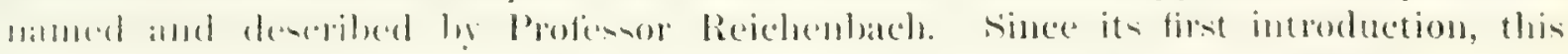

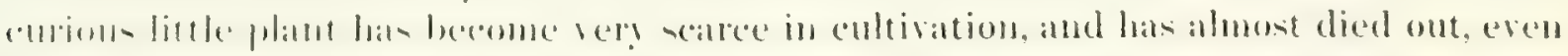

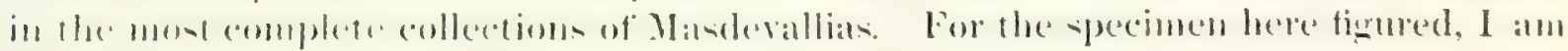

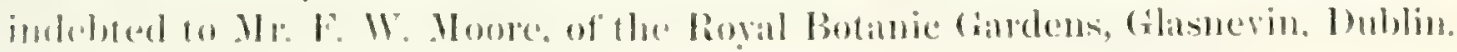

livplanartiun of l'latte:

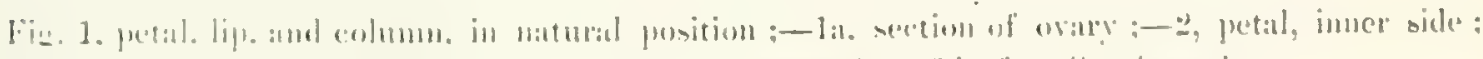

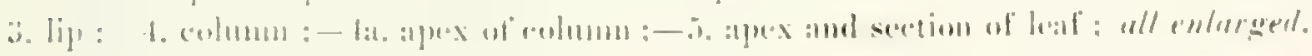





\section{SECTION XV.}

\section{TUBULOSAE Rchb.}

THE - precien included in this fecetion are remarkable for the very long narrow tube formed by the sepals. By the advice of Consul Lehmann I place M. mosen in this eroup with M. rentriculeria.

2 species figured :

Masdevallia rosea Lindl.

rentricularia Rehb. f. ( not in culticution.)

Not in cultiration:

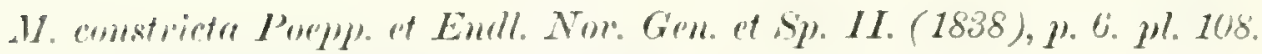
melenleren Limell. Oreh. Limd. (1846), p. 4. ventricularia Rehb. f. (sep Plute) 




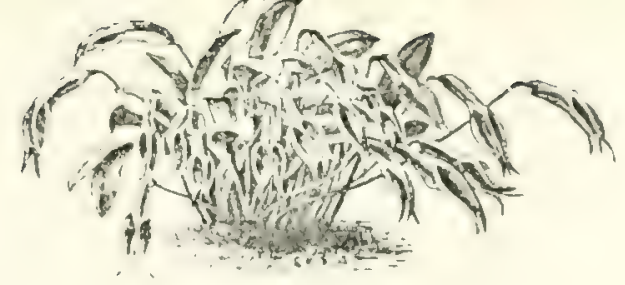

\section{MASDEVALLIA ROSEA Lindl.}

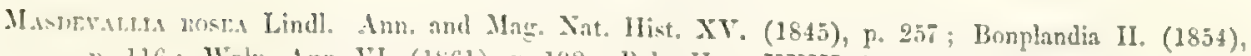
P. 116; Walp. Ann. VI. (1\$61), p.192; Belg. Hort. XXIII. (1873), 1. 360; Otia Bot. Hamb.

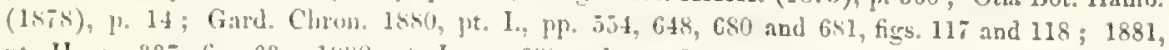
pt. II., p. 337, fig. 63: 1k82, pt. I.. P). G2S and 644, fig. 101 ; Orchidophile (Godefrog) 1882, 13. $345 ; 1566,10.235$.

Leaf 5 or 6 incles loner and albout 1 inch wide, whlong-lanceolate, carinate, acutely tridenticulate,

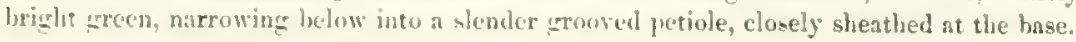

I'eduscle 5 or 6 inches lon: very sender, terete, erect, pale green, with one or two shenthing bracts ; thowerine luact 3 inch lone, shenthing, apiculate, bruwnish.

( wary about 1 inch long, triangular, with roundcd angles, light green, sometimes brown or blackish.

Scrpals: dorsil sepal mited to the Jateral sepals for about if inch, forming a narruw tube, bright red and shinine on the onter surfice and shacd with rose-lilac, free portion triangular for $\frac{1}{8}$ inch, rose-lilac, tapering into a very slonder tail 1 or $1+$ inch long, bright red; lateral sepals cohering for 19 inch, free

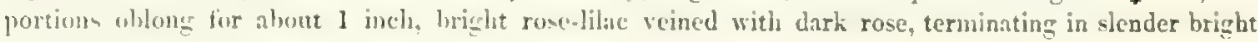
red tails :? or ! inch long.

l'ctals is ineh long, ligulate, an irled on both narerins near the base, apex tridenticulate, very pale yellow.

Lij! it inch lons, pandurate, pale ycllow and sliglity hairy at the base, with two pink longitudinal keeds, alexes dark reddials-purphle, covered with stift hairs.

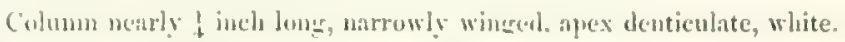

$\mathrm{M}$

ASUEVALLIA ROSEA wa dincorered in 142 or 1S43, by Theodore Hartweg, near Loja in Ecuador, and from dried specimens collected by him it was first maned and dencribed by Dr. Lindley in 1845. No importation of living plants was effected until 1sso, when Consul Lehmann succeded in bringing home a quantity. In 1sn. the first living flowers seen in Europe were produced from these plants distributed annong varions private collections of Orehids. The flower varies slighty in size and in brilliancy of colom, and the plant drawn for the aceompanying plate was considered by Profienor Reichenbach to be a rather narrow and dark-flowered variety. The stem is llatably onc-flowered, although in a wild state stems bearing two and even three flowers lare been met with, and have aloo oceanionally appeared in cultirated plants.

C'onul Lehmann sends sue the following note:

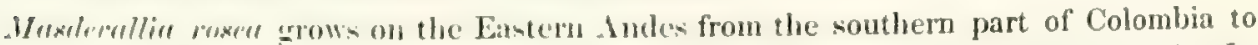
Uhe south of Eevadot at an clevation of $2,800103,200$ metres $(9,100$ to 10,400 feet). In inir I met with it on the Volcano Tumgumarua, and subsequently in the Eastern Andes of Cucruca and Lopia, in the south of Ecuador. It grows on trees in dense and damp wook. The anmul mean temperature of the regron ranges between $10^{\circ}$ and $12^{3} 5$

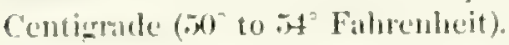

The ouly phunts cxisting in Europe originute from an importation of mine made in $1 R \rightarrow 0$. from the Andes of Pasto in Colombia. In its natural habitat the plant flowers in

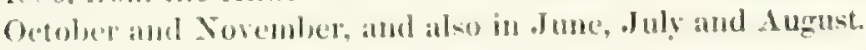

F. C. LeHMaxs.

Explanations of Plate, drawn from a plant at Newhattle - Dbixy:

Fij:- 1, petal, Jij. and colum, in matural position;-1a, section of ovary;-2, petal, inner side:-

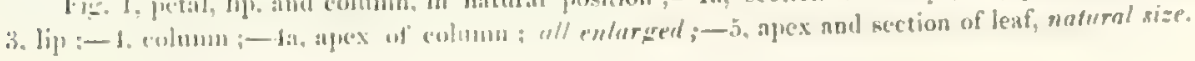






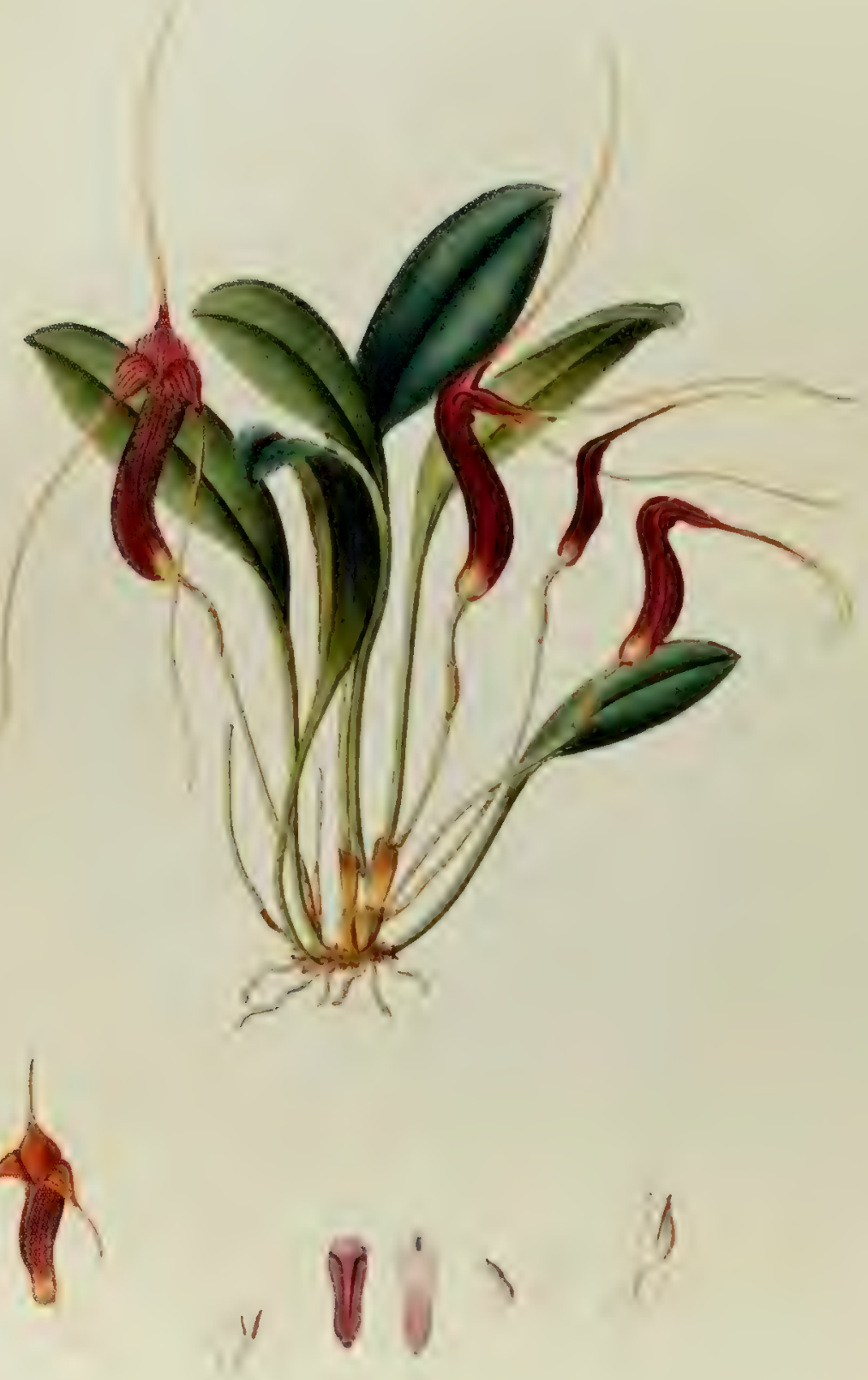




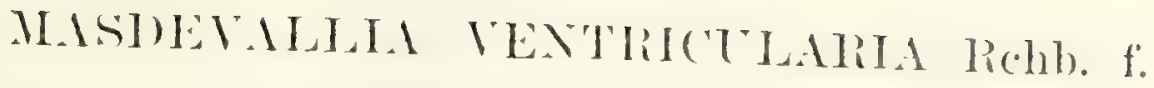

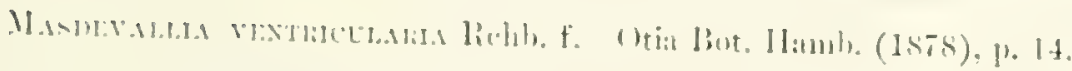

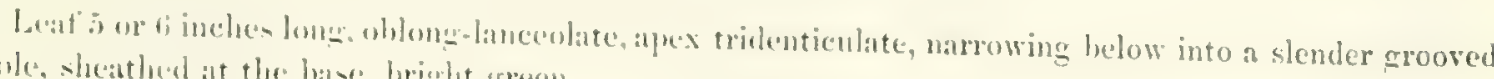

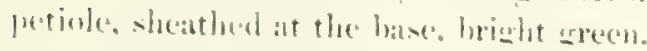

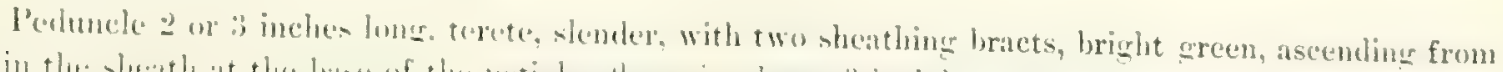

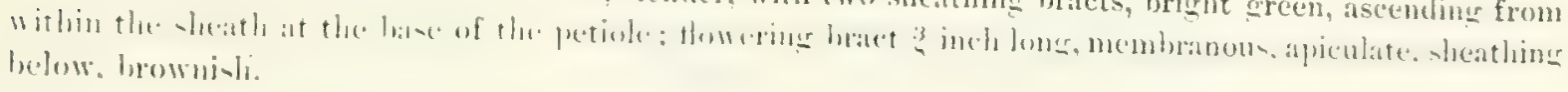

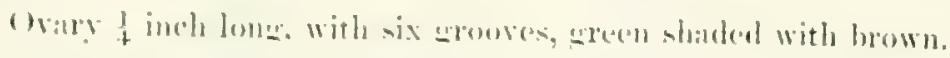

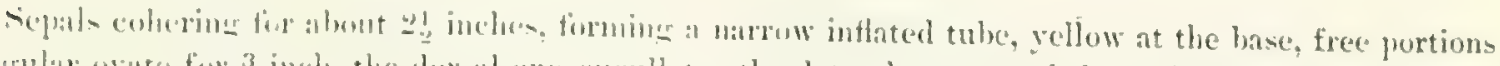

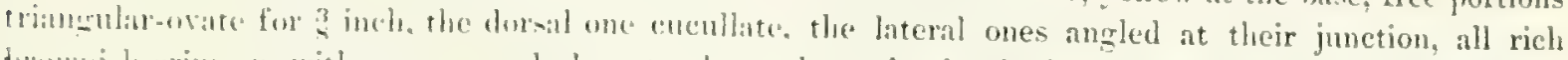

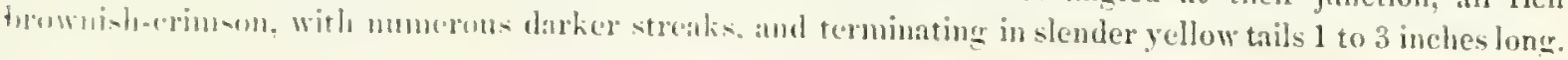

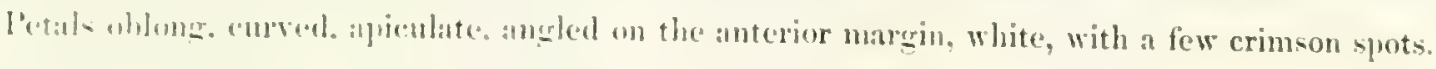

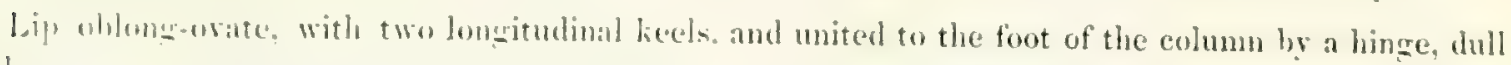
minjl:

Colmum a litte shorter than the petals. erect, apex denticulate, white.

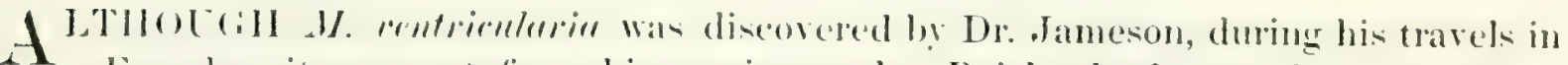
Eenador. it was mot from his specinems that Reichenhach named and described

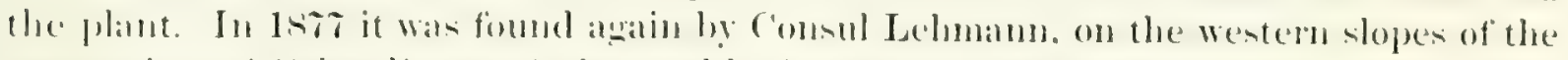
monntains of Calacall. near (guite. and he informs me that it was upon the small shorttailed form. fig. of of the aceompanginge Plate. that Reichenhach bestowed the name, and

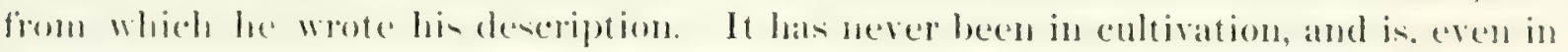

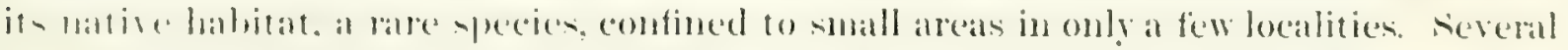

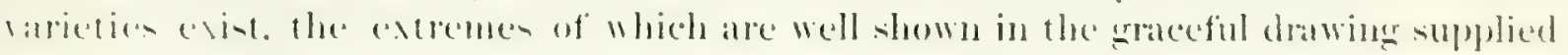

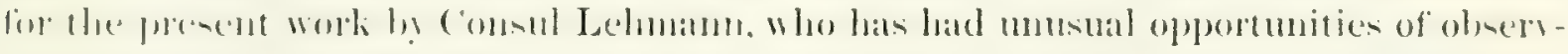

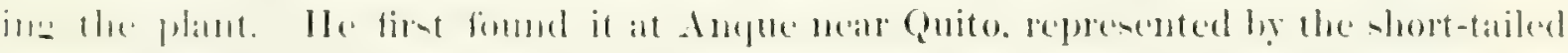

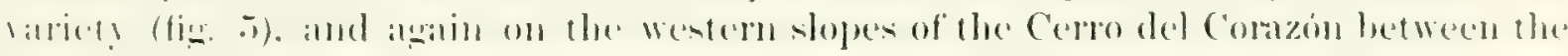

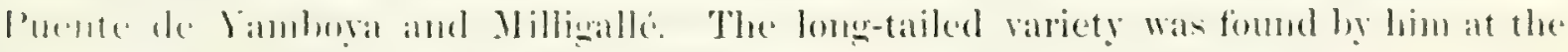

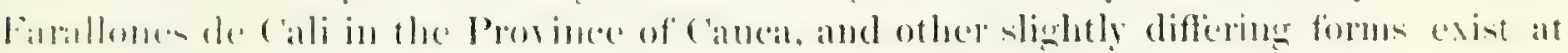

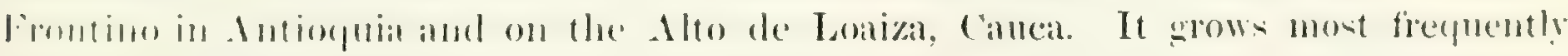

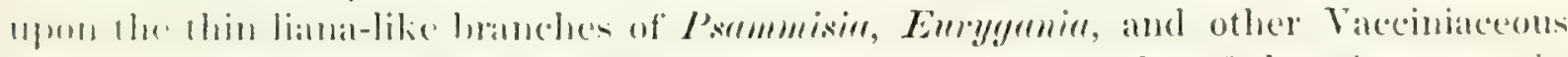

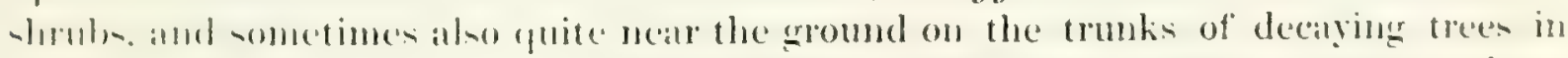

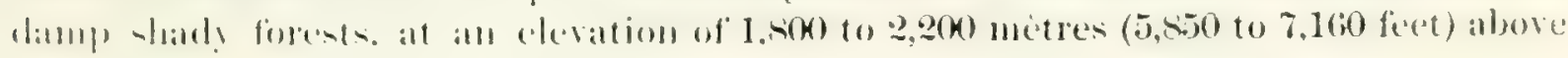
sin-lind.

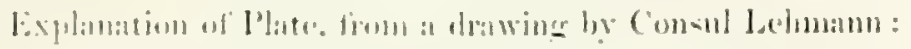

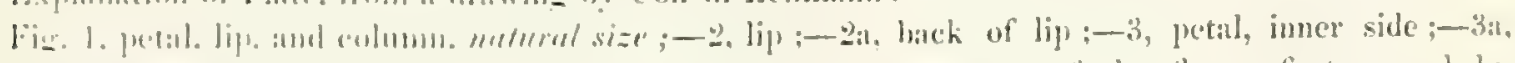

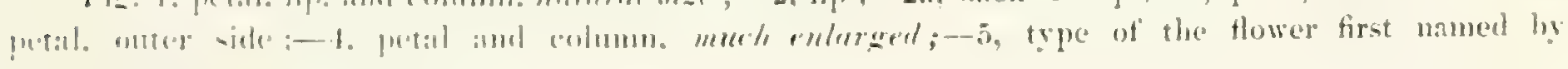

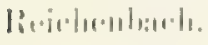





\title{
GENUS MASDEVALLIA.
}

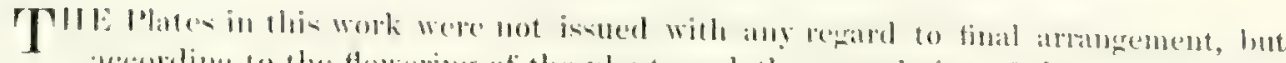
alcortis! 10 the flowering of the plants and the completion of the drawings, and they are, therefore, not mumbered. As the trents is divided into sections, which there is 110 leaten foplacing in any particular order, they are numbered, and are, as well as the Plates contanged in carch Section, armaged alphabetically. Each name in the index refers to the mumber and name of the section to which the plant is assigned, or, if a syomym, to the aceepted name of the plant. The names of all species and rarieties not figured in the bosk are printed in italies, and to those now excluded from the cienus Mandevallia, the bathes of the Genem in which they are classed are added.
\end{abstract}

I. ablueviata, ficetion 1. Amandie.

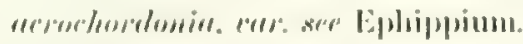
ereprilublus, = civilis.

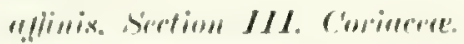
"llielle, =infratcta. anmbilis, section 11. Coccineat. Amerular, siection I. Amomele. forrsienre, $x$ see Tovarensis. amerthystime, scriphosegulume.

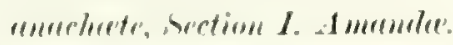

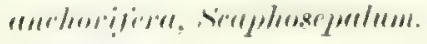

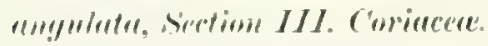

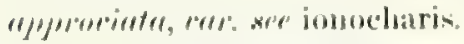
aristatil, Seetion V111. Polsantlate. Amminii. Reetion XIII, Triangulares.

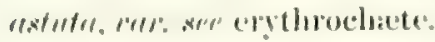

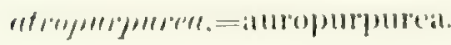
altenuntal. Secetion V'1. Minutie.

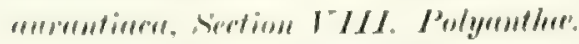
merentienere. meses militaris.

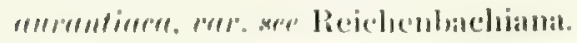

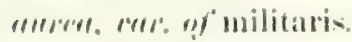

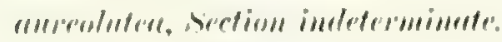

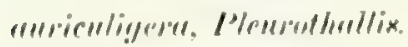
atropurpurea, section VIII. Polyanthat.

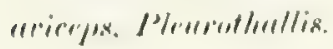

Backlousiana, var. Section XI. Salecelabiatic.

IBarlakina, Section 11. Coecineat.
M. bella, Section XI. Saccolabiatie. Benerlicti,=Houtteana. licolor, sep maculata. biflorn,=caloptera. Boflduevt, ver: see militaris. Bomplamlii, Spetion III. Corincere. brevis, Scaphosephahm.

Bruchmillevi, = coriacea.

Buccinutor, Section VIII. Polyouthe. Bubbirlycene, erer. of Chimera.

caresin, Section indeterminats. caloptera, Section I. Amandie. colopterocrempres setion I. Amandee. calum, Section X. Reichenbachiane. crelyptrutu, section $I V$. Crecullute. campyoglossa, Section III. Coriaces. crudivlu, = Tovareusis.

Carderi, Section XI. Saccolabintie. caudata, Section III. Triangulares. cenclutr-Estrolle, $X$ see caudata. C'nyenuensiz, Section III. Corincere. Clelsoni, $x$ see Veitchiana. Chestertonii, Section XI. Saccolabiats. Chimari, Section XT., Saccolabiata. chlorurue, Section III. Coriacene. Chombulensis, suction VI. Ninute. cimmumomen, section VIII. Polyanthe. citvint, enr: see militaris. eivilis, Section III. Coriacese. 

II. coccinea, Section II. Concines. colibri, = Ephippium. comstricta, Section $\mathbf{T} \boldsymbol{V}$. Tulmuloree. coriacea, Section III. Coriacese. corniculata, Section IV. Cucullatx. Costaricensis, = marginella. Courtemldiena, $x$ ser cundata. crassicaudata, ran. see polysticta. cucullata, Section IV. Cucullate. culex, Pleurothallis.

cuprea, Section VIII. Polyanthe. cupularis, Section III. Coriacer. eurtipes, Section VIII. Polyantha.

Davisii, Section II. Coccince.

Dayana, Cryptophorunthre. demissa, Section X. Reichenbachianz. dolosa, rav, of Chimata.

Echilna, Scaphosepalum. Eduardi, Section IX. Racemosa. Hephanticeps, Section III. Coriaceæ. elephanticeps rar. pachysepala, = Mooreana.

ollipes, Section III. Coriacece.

Ellisima, $x$ see militaris.

rusata, Section III. Curincere. Lphippium, Section VIII. Polyanthat. "rinacea, Scaphosepalum. urythrochete, Section XI. Saccolabiatæ. Estrada, Section XIII. Triangulares. expanse, Section XIII. Triangulures.

julcreyo, Section V. Fissa. tarscinta, sectim indeterminate. fincstrate, Cryptophosenthus. fisva, ear. see maculata. Maveala, Section VI. Minuta. Horibunda, Section II, Triangulares. forgetiana, cur. see infracta. fractiflexa, Section III. Coriacea. fragrans, section III. Coriacer. Frascri, $x$ see militaris. fulvescens, Section X. Reichenbachiand.

Grivinna, $x$ see Veitchiana.

Ginleatr, Section indeterminute.

Galcottirme $=$ florilumula.

Gargunua $=$ olephouticeps.

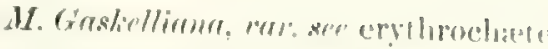

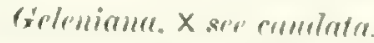
arenmota, Secetion XIV. Triaristellat

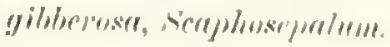
glosereprongur, Pleuruthallis.

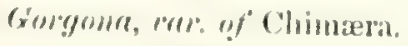
gracilenta, INemethallis. Gustari, sections I. Amamele. Euttulata, section VII. Polyanthe. Gruyanensis, Sectim iuleteminate.

Harryana, corr. sere eoceinesa. hememecrentha, Srefiom VIII. Polyanthen hermetestictu, Section iudsterminate. Herthii, $x$ see militario heteroptere, section indeterminate. heterotejulu, section III. Corincen. himns, Section VI. Mimute. hicroglyphica, section XIII. Triangulines.

Hinclisiona, x ser Tovarensis. Iloutteana, Section XI. Saccolabiatae. hymestruthe, siofiom IIII. Trimgnline's.

hypontiscus, Cryprophenruthus.

ignen, $=$ militari-

incequalis, Section SIII. Trimngulmex implata, ral: see corniculata.

infracta, fection VIII. Polvanthe. ionocharix, bection Xill. Triangulare

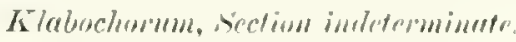

leeriss. Sisction III. Coriencere. Lansbergie, sisction VI. Minuter. later, section VIII. L'ulyenthe. Latuchealla, section III. Corracent

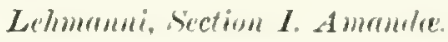
leontoslossa, section III. Coriacese. leprider, section III. Curiacree.

Limleni, = coceinen. Limlenireme, $=$ floribundil.

Licingstomiemer, Jicurothallis. longicumeleter, = infiactit.

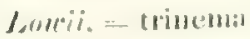

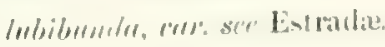

murpurlitm, = Chestertunii.

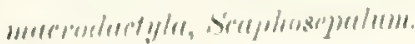





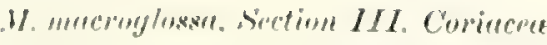
macrutra, Fecotion 17 . Cueullate. maceulatit, section VIIL. Polyauthat maryulla, Section X. Reichenbachinut. Merslerllinun, enes see militaris. Mrsarnugruna, rur, see militaris. Mustortan, Section VIII. Polyanther.

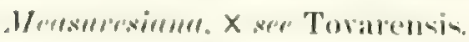
menireryllinm, soction inderemimele. melanop)us, section I. Amandat.

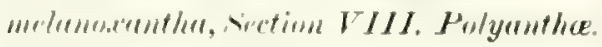
mefory-is, = picturata.

molen!fus, section indeterminate.

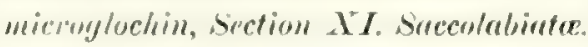
militaris, Section I1. Coccinere. minnele, Sraction VI. Minnte. molonsus, section 511. Sultutriens. Mooreatua, Rection III. Coriaceats.

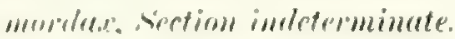
.lumblymen, $x$ ste militaris. III-cosir, Section VII. Muscoves. myrinstigme, = toribunda. nidificil. Section VI. Minutie. Tormrmai. = Reichenhachiana. necterinat. Section XI. Saccolabiatate

O'Brientana, section X11. Sittatrices. enthereles, seaphosepulum. ophioghasi, rection VI. Minmat.

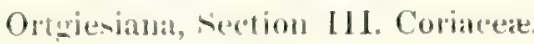
pachyantlat, section III. Coriacente pachoura, section I. Amandx.

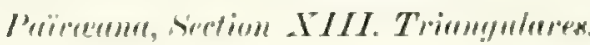
pelliele, ron: ace Xanthina. juralime, Sinetion 1II. Coriucere.

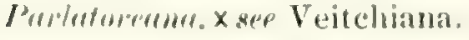
Peri-teria, Section III. Coriaceat. picturata, section V. Fisse.

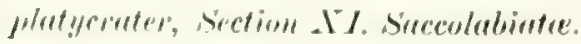
platygloma, section III. Coriaceat. platyrhehis, Henouluallis. jolyuntha, rous see Schlinii. polystieta, section 1. Amandat. poreclliceps, sections 111. Coriacers.

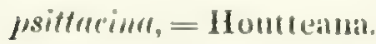
julteinuris, sconplonstyulum.
II. pumile, section FI. Alinuter. puenctete, scopherejulum.

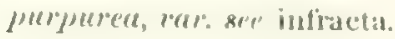
pusilla, Section XI. Saccolabiatat. pusiola, Section J"I. Minntre. racenosin, Section $1 \mathrm{X}$. Ralcemosie. radiosa, Section X1. Saccolobiatie. Reichenbachiank, Section X. Reichenbachianit.

Roezlii, var. Section XI. Saccolahiate. Rolfeana, Section $\mathbf{X}$. Reichenbachinnt. Rosea, Section XV. Tubulosit. rurolutea, = civilis.

Sultutrix, section V11. Maltatriers. Sceptrum, var. sep Seblimii.

Schlimii, Section VIII. Polyautha. Schroederiana, section $X$. Reichenbachianat.

senilis, zor: of Chimera.

severa, rav of Chimera.

Shutleworthii, = caudatu. simula, Section XII. Saltatricem. sororcula, = Mooreana.

Spectrum, Section XI. Succolnhintre. splendens, $\mathrm{X}$ see Veilchiam. splendida, $x$ see Veitchian. sjlendida, car. of Chinnzera. Syrucei, section indeterminate. Stoburtianr, rar, see militaris. striatella, Section III. Coriaccit: strumifera, Section indeterminnt". Surinamensis, Section isuletrmimato. stcerticefolia, Scaphosepalum.

torta, Section III. Coriacest. Tovarensis, Section VIII. Polyauthat. triangularis, Section XIII. 'Triangrulares. triaristella, Section XIV. "Yriaristellit". trichete, = gemmata tricolor, Section indeterminate. triculor, section XIII. Trinngulenes. trilactylites, = triaristella. trillens, section I. Amanda. teirinutata, Section VIII. I"ulyanllues. triglochin, Section XIV. Triaristellas. minuni, section XI. Saceolabiate. 
M. triquetra, Section VIII. Polyanthe. Trochilus, = Ephippium. Troglodytes, Section XI. Saccolabiatæ. Tubeant, Section . YI. Saccolabiate. tubulosa, Section XV. Tubulosa. uncifera, Section V. Fissa. uniflora, Section XIII. Triangulares. urostachya, Section VIII. Polyantha.

Veitchiana, Section II. Coccineæ. velifera, Section III. Coriaceæ. velutina, Section $\boldsymbol{X I I I . T r i a n g u l a r e s . ~}$ ventricularia, Section XV. Tubulosse. verrucosa, Scaphosepalum.
M. Vespertilio, Section XI. Saccolabiatt.

Wageneriand, Section XIII. Triangulares.

Wallizii, ver. of Chimzera.

Wendlandiana, Section VI. Minutie. Wimnima, var. of Chimæra.

xanthina, Section XIII. Triangulares. xanthocorys, var. see caudata. xanthorlactyln, Sretion I. Amoudre. xipheres, Scophoxepnlum. xylina, Section VIII. Polyanthet.

Yauaperyensis, Section III. Coriaces.

FINI). 



\section{SECTION INDETERMINATE:}

Solithe is known about the following species that it is impossible to class them in any Section.

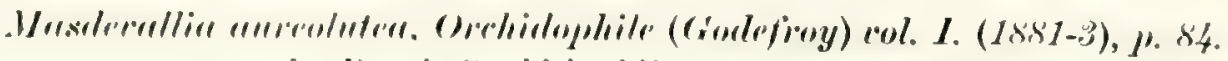

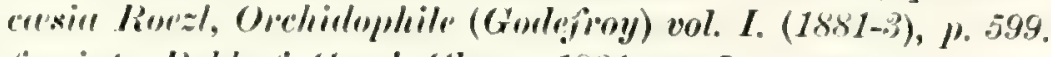

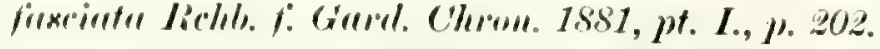

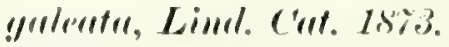

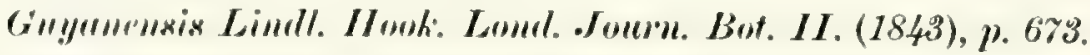

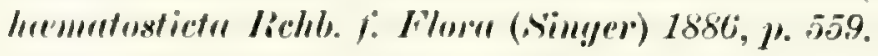

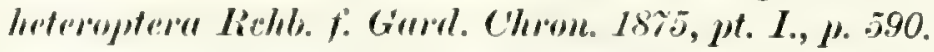

meincryllimm lichb. t: Flon" (singer) 1886, p. 558.

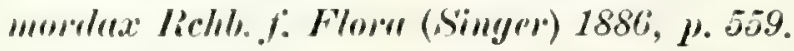

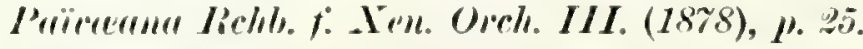

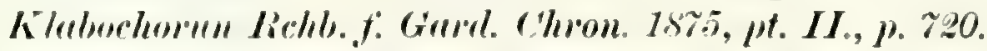

siprencei lichb. t: Otiu Bot. Ilomb. (1878) 1) 17.

strumiter" Rehb. f: Flow" (Singer) 1886, p. 560.

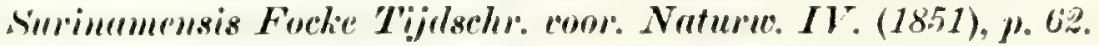

triculur lichl t: Limmen XXII. (1849), p. 818. 
, 


\section{SPECIES}

NOW HXCLUDED FROM THE

\section{GENUS MASDEVALLIA.}

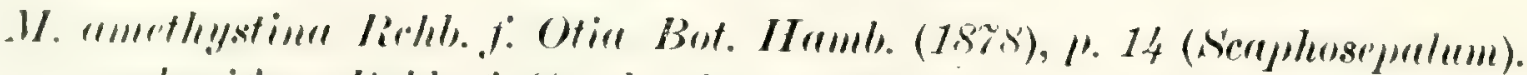

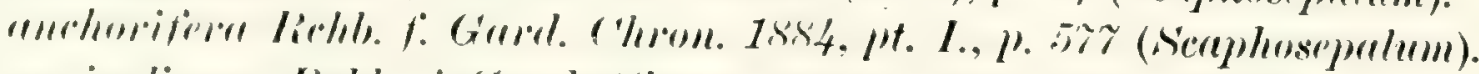

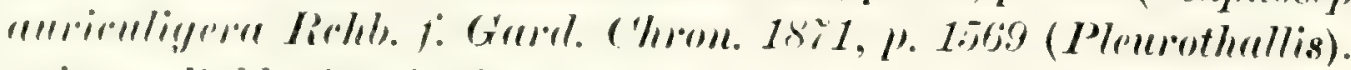

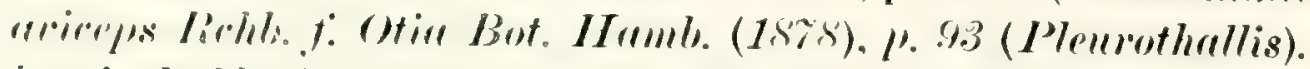

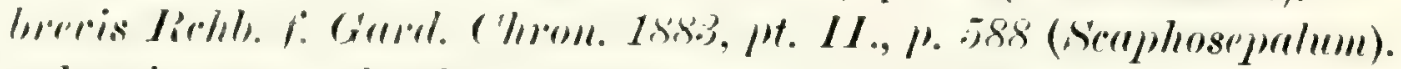

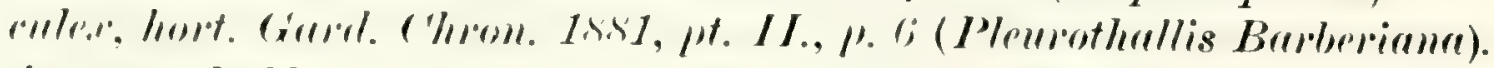

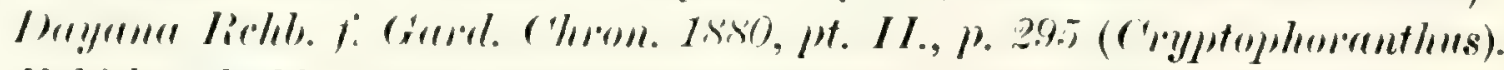

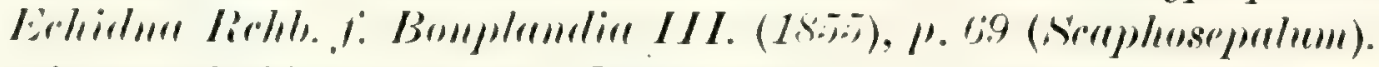

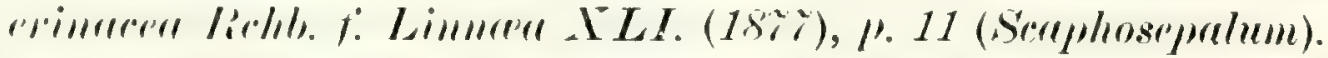

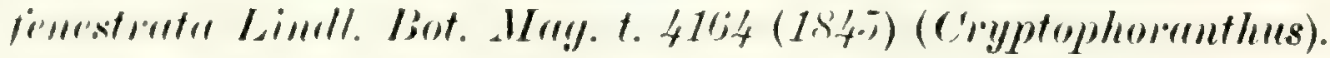

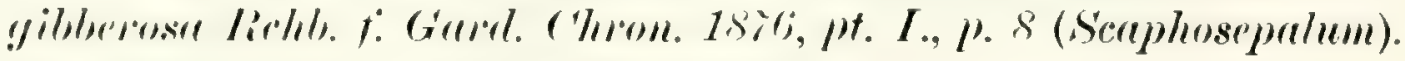

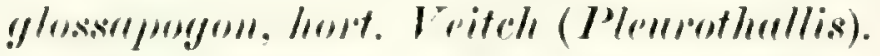

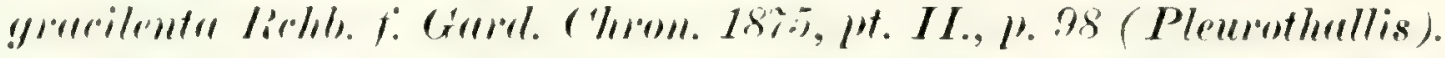

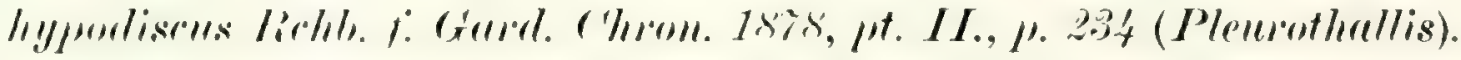

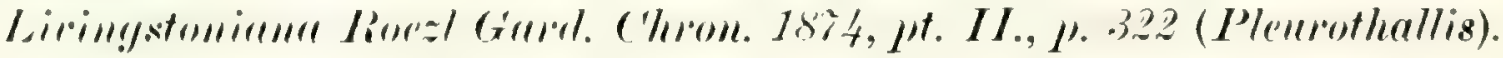

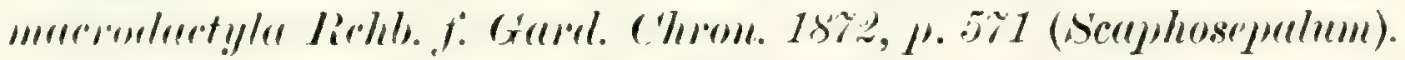

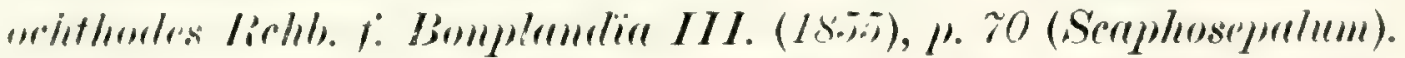

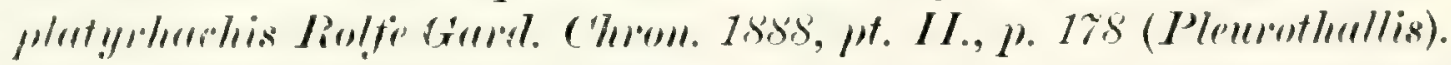

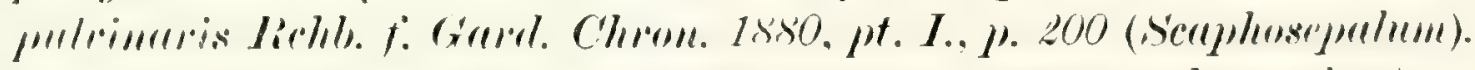

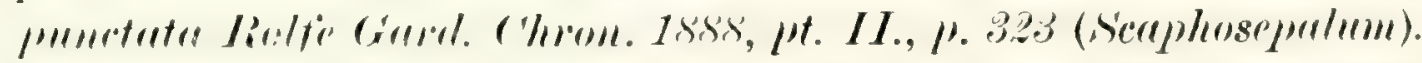

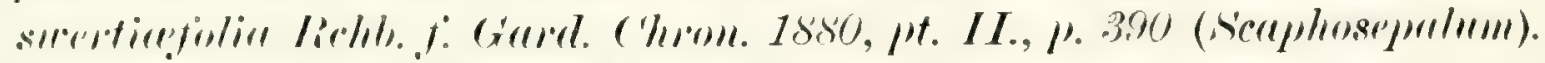

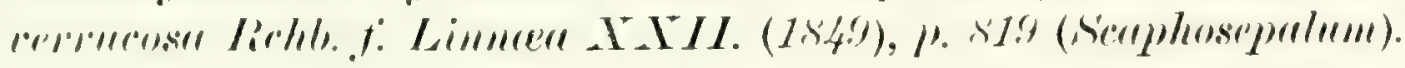

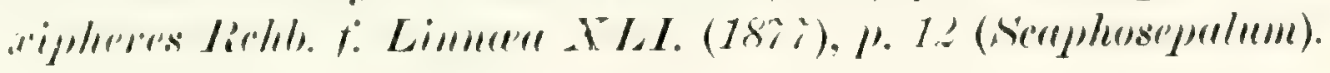





\section{errata:}

1. under M. Macrura

in ref. to Gard. Chron. 1881,

for 136 read 336

2. under $M$. aristata

dele. ref. to Gard. Chron. 1881

3. under M. Reichenbachiana

for Frazí read Irazú 


